Keywords: SCIX, DWPF,

Titanium, Glass, Durability

Retention: Permanent

\title{
Impacts of Small Column Ion Exchange Streams on DWPF Glass Formulation: KT07-Series Glass Compositions
}

K. M. Fox

T. B. Edwards

December 2010

Savannah River National Laboratory Savannah River Nuclear Solutions, LLC Aiken, SC 29808

Prepared for the U.S. Department of Energy under contract number DE-AC09-08SR22470.

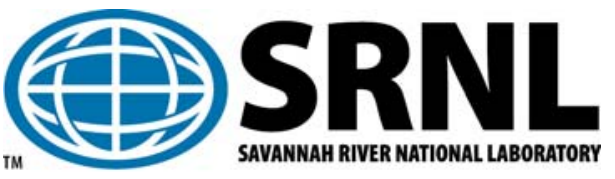


SRNL-STI-2010-00759

Revision 0

\section{DISCLAIMER}

This work was prepared under an agreement with and funded by the U.S. Government. Neither the U.S. Government or its employees, nor any of its contractors, subcontractors or their employees, makes any express or implied:

1. warranty or assumes any legal liability for the accuracy, completeness, or for the use or results of such use of any information, product, or process disclosed; or

2. representation that such use or results of such use would not infringe privately owned rights; or

3. endorsement or recommendation of any specifically identified commercial product, process, or service.

Any views and opinions of authors expressed in this work do not necessarily state or reflect those of the United States Government, or its contractors, or subcontractors.

\section{Printed in the United States of America \\ Prepared for \\ U.S. Department of Energy}




\section{REVIEWS AND APPROVALS}

AUTHORS:

K. M. Fox, Process Technology Programs

Date

T. B. Edwards, Applied Computational Engineering and Statistics

Date

TECHNICAL REVIEW:

D. K. Peeler, Process Technology Programs

Date

APPROVAL:

C. C. Herman, Manager

Date

Process Technology Programs

F. M. Pennebaker, Manager

Date

SRNL SCIX Program

S. L. Marra, Manager

Date

Environmental \& Chemical Process Technology Research Programs

J. E. Occhipinti, Manager

Date

Waste Solidification Engineering

T. H. Huff, Manager

Date

SCIX Engineering 


\section{EXECUTIVE SUMMARY}

This report is the third in a series of studies of the impacts of the addition of Crystalline Silicotitanate (CST) and Monosodium Titanate (MST) from the Small Column Ion Exchange (SCIX) process on the Defense Waste Processing Facility (DWPF) glass waste form and the applicability of the DWPF process control models. MST from the Salt Waste Processing Facility is also considered in the study. The KT07-series glasses were selected to evaluate any potential impacts of noble metals on their properties and performance. The glasses characterized thus far for the SCIX study have not included noble metals since they are not typically tracked in sludge batch composition projections. However, noble metals can act as nucleation sites in glass melts, leading to enhanced crystallization. This crystallization can potentially influence the properties and performance of the glass, such as chemical durability, viscosity, and liquidus temperature. The noble metals $\mathrm{Ag}, \mathrm{Pd}, \mathrm{Rh}$, and $\mathrm{Ru}$ were added to the KT07-series glasses in concentrations based on recent measurements of Sludge Batch 6, which was considered to contain a high concentration of noble metals. The KT04-series glasses were used as the baseline compositions.

After fabrication, the glasses were characterized to determine their homogeneity, chemical composition, durability, and viscosity. Liquidus temperature measurements are also underway but were not complete at the time of this report. The liquidus temperature results for the KT07series glasses, along with several of the earlier glasses in the SCIX study, will be documented separately. All of the KT07-series glasses, both quenched and slowly cooled, were found to be amorphous by X-ray diffraction. Chemical composition measurements showed that all of the glasses met their targeted compositions. The Product Consistency Test (PCT) results showed that all of the glasses had chemical durabilities that were far better than that of the Environmental Assessment benchmark glass. The measured PCT responses were well predicted by the current DWPF Product Composition Control System (PCCS) durability models. The measured viscosity values for each KT07-series glass were acceptable for DWPF processing and were well predicted by the current PCCS model.

Overall, the results show that the inclusion of relatively high concentrations of noble metals (in terms of expected values for a DWPF sludge batch) had no significant impact on the properties and performance of these glass compositions. There were no significant differences in the measured properties when compared to those of the KT04-series glasses, which did not contain noble metals. Liquidus temperature measurements are still underway and there may be an impact of the noble metals on those measurements. However, no adverse effects were noted in terms of crystallization after slow cooling.

At the completion of these studies, all of the data generated will be reviewed with regard to the applicability of the DWPF PCCS models and recommendations will be made as to whether the validation ranges of the current models can be extended, or whether some or all of the models need to be refit to allow for the incorporation of the SCIX streams. As changes are made to the projected sludge compositions and the volume of the SCIX material, additional evaluations should be performed. 


\section{TABLE OF CONTENTS}

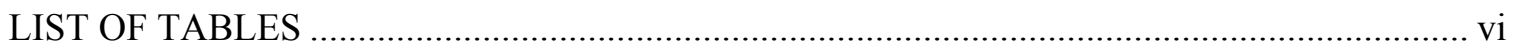

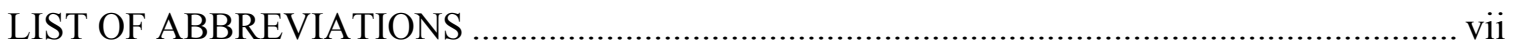

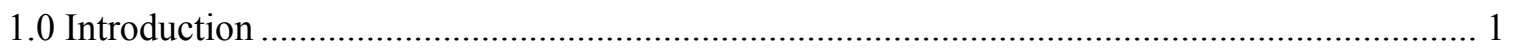

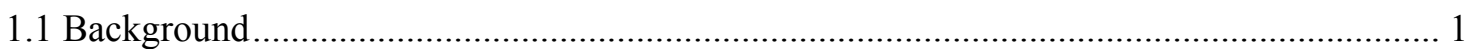

1.2 Potential Impacts of SCIX on DWPF Glass Formulation................................................... 1

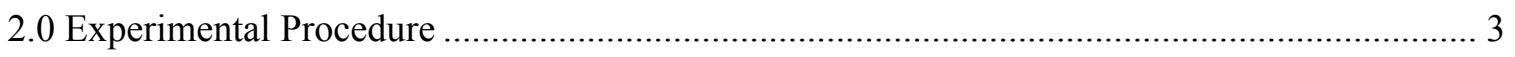

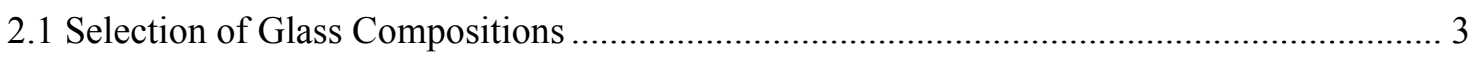

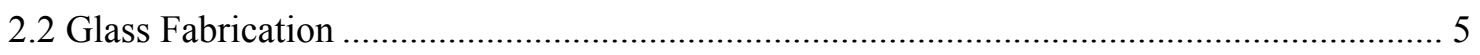

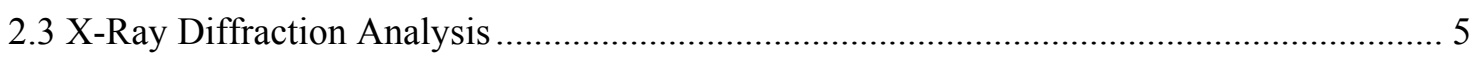

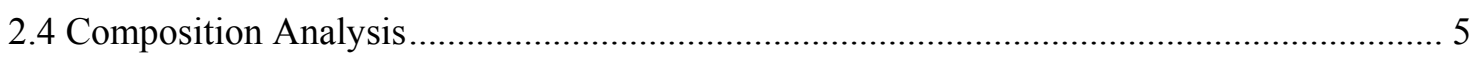

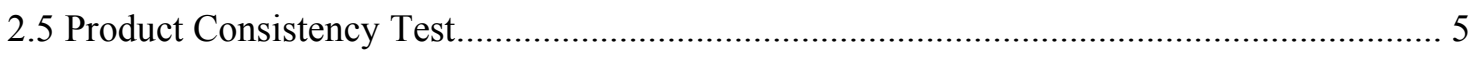

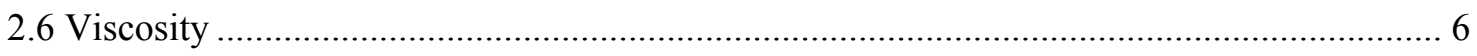

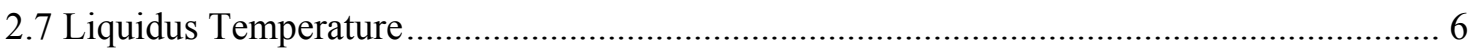

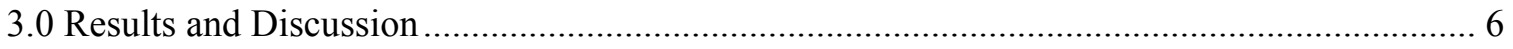

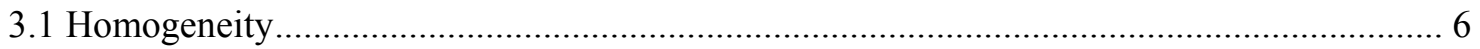

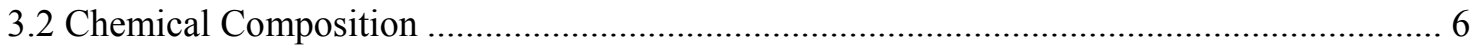

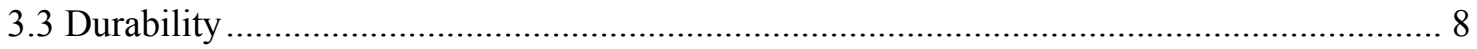

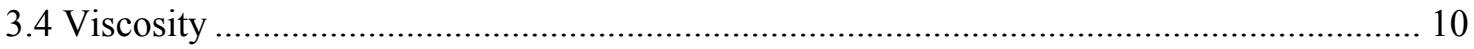

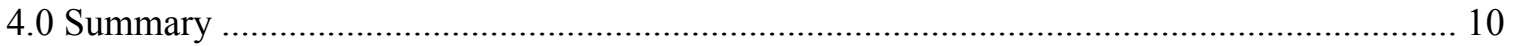

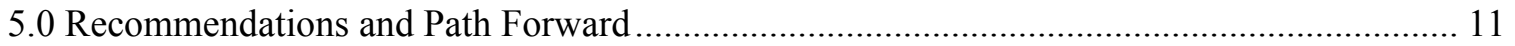

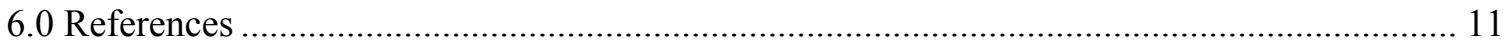




\section{LIST OF TABLES}

Table 2-1. Target Noble Metals Concentrations (in Glass) for the KT07-Series Glasses.............. 3

Table 2-2. Target Compositions for the KT07-Series Glasses................................................... 4

Table 3-1. Results form Samples of the Multi-Element Solution Standard. ................................. 9 


\section{LIST OF ABBREVIATIONS}

$\begin{array}{ll}\text { AD } & \text { Analytical Development } \\ \text { ANOVA } & \text { ANalysis Of VAriance } \\ \text { ARM } & \text { Approved Reference Material } \\ \text { CCC } & \text { Canister Centerline Cooled } \\ \text { CST } & \text { Crystalline Silicotitanate } \\ \text { DWPF } & \text { Defense Waste Processing Facility } \\ \text { EA } & \text { Environmental Assessment } \\ \text { HLW } & \text { High Level Waste } \\ \text { ICP-AES } & \text { Inductively Coupled Plasma - Atomic Emission Spectroscopy } \\ \text { LM } & \text { Lithium-Metaborate Fusion } \\ \text { MAR } & \text { Measurement Acceptability Region } \\ \text { MST } & \text { Monosodium Titanate } \\ \text { PCCS } & \text { Product Composition Control System } \\ \text { PCT } & \text { Product Consistency Test } \\ \text { PF } & \text { Sodium Peroxide Fusion } \\ \text { PSAL } & \text { Process Science Analytical Laboratory } \\ \text { RMF } & \text { Rotary Micro Filtration } \\ \text { SCIX } & \text { Small Column Ion Exchange } \\ \text { SRAT } & \text { Sludge Receipt and Adjustment Tank } \\ \text { SRS } & \text { Savannah River Site } \\ \text { SWPF } & \text { Salt Waste Processing Facility } \\ \text { TL } & \text { Liquidus Temperature } \\ \text { XRD } & \text { X-ray Diffraction } \\ & \end{array}$




\subsection{Introduction}

\subsection{Background}

The Savannah River Site (SRS) Liquid Waste contractor will begin a process referred to as Small Column Ion Exchange (SCIX) to disposition salt solution in fiscal year 2014. In the first step of the process, salt solution retrieved from various waste tanks will be struck with Monosodium Titanate (MST) to remove key actinides and Sr. The salt solution will then be processed using Rotary Micro Filtration (RMF) to remove the MST and any insoluble solids. The MST and insoluble solids will accumulate on the bottom of Tank 41. The filtrate from RMF will be fed to ion exchange columns, also in Tank 41, to remove the ${ }^{137}$ Cs using Crystalline Silicotitanate (CST) resin. The decontaminated salt solution from SCIX will be sent to the Saltstone Facility for immobilization in grout. The ${ }^{137} \mathrm{Cs}$-laden CST resin will be sluiced and ground for particle size reduction, then sent to the Defense Waste Processing Facility (DWPF) for immobilization in glass. These processes mirror the current disposition paths for streams associated with the Salt Waste Processing Facility (SWPF), which is under construction and will run concurrently with SCIX.

The MST and insoluble solids from Tank 41 will periodically be transferred to a sludge batch preparation tank (e.g., Tank 42 or Tank 51) as part of the High Level Waste (HLW) sludge batch preparation process for DWPF. The ground, ${ }^{137} \mathrm{Cs}-\mathrm{laden}$ CST material (hereafter referred to simply as CST) from SCIX will be periodically transferred to Tank 40 prior to being processed at DWPF. Periodic additions of CST to Tank 40 would result in a changing composition of each sludge batch as it is processed since Tank 40 serves as the feed tank for the DWPF. Work is currently in progress to determine the feasibility of dropping the ground CST into Tank 41. If ground CST can be dropped into Tank 41 (depending on heat loading issues, among others), the CST would be sent to Tank 42 or Tank 51 using an existing transfer line. Therefore, the studies of SCIX impacts on DWPF glass formulation will encompass scenarios where the CST is sent to either Tank 40 or a sludge batch preparation tank. MST from the SWPF is also considered in the study.

This work was initiated by a DWPF Technical Task Request ${ }^{1}$ and was performed following a Task Technical and Quality Assurance Plan. ${ }^{2}$

\subsection{Potential Impacts of SCIX on DWPF Glass Formulation}

The MST and CST from the SCIX process will significantly increase the concentrations of $\mathrm{Nb}_{2} \mathrm{O}_{5}$, $\mathrm{TiO}_{2}$, and $\mathrm{ZrO}_{2}$ in the DWPF feed. Other constituents of MST and CST $-\mathrm{Na}_{2} \mathrm{O}$ and $\mathrm{SiO}_{2}-$ are already present in high concentrations in DWPF glass; thus their influences are well understood. The increased concentrations of $\mathrm{Nb}_{2} \mathrm{O}_{5}, \mathrm{TiO}_{2}$, and $\mathrm{ZrO}_{2}$ will likely have some impact on the properties and performance of the DWPF glass product. Properties such as the liquidus temperature, viscosity, and rate of melting of the glass may be impacted. The performance of the glass, particularly its chemical durability as it pertains to repository acceptance requirements, may also be impacted. The DWPF uses a set of semi-empirical and first-principles models referred to as the Product Composition Control System (PCCS) ${ }^{3}$ to predict the properties and performance of a glass based on its composition since it is not possible to measure these attributes during processing. The objective of this study is to evaluate the impacts of the SCIX streams on the properties and performance of the DWPF glass product and on the applicability of the current process control models.

This report is part of a series of studies on the potential impacts of SCIX on DWPF glass. Fox and Edwards recently performed a paper study evaluation using updated projections for sludge 
batch compositions and SCIX CST and MST addition rates. ${ }^{4}$ This study found that, as a result of the updated composition projections, several viable options were predicted to be available for incorporation of the SCIX streams into either Tank 40 or a sludge batch preparation tank. Transfer of the CST to a sludge batch preparation tank was the preferred option since it allowed more compositional flexibility for frit development while maintaining sufficient projected operating windows. The report again identified several assumptions and limitations associated with the current PCCS models, and recommended that these be further evaluated.

The first report on experimental results in this series covered glass compositions identified as the KT01, KT02, KT03, and KT04-series. ${ }^{5}$ The results presented in that report showed a reasonable ability to incorporate the anticipated SCIX streams into the DWPF-type glass compositions studied, with $\mathrm{TiO}_{2}$ concentrations of $4-5 \mathrm{wt} \%$ in glass. The durability and viscosity models satisfactorily predicted the measured values for the study glasses with the exception of a small number of extreme compositions. It was shown that the liquidus temperature model may need to be adjusted to correctly predict the liquidus temperatures of glasses including the SCIX streams based on the data measured.

The second report on experimental results covered compositions identified as the KT05 and KT06-series. ${ }^{6}$ The KT05-series glasses were selected, fabricated, and characterized to as a more fundamental study of glass compositions where iron titanate crystals had been previously found to form during a study of high waste loading glasses for future DWPF processing. ${ }^{7}$ These glasses contained high $\mathrm{TiO}_{2}$ concentrations, but may be outside the compositional region that is directly of interest to DWPF. Formation of these crystalline phases in these glasses was confirmed. However, the glass compositions from which these phases formed are different from the current projections for SCIX incorporation into DWPF sludge batches. Increased $\mathrm{Na}_{2} \mathrm{O}$ concentrations had little if any impact on reducing the propensity for the formation of the iron titanate crystalline phases. The KT06-series glasses were selected, fabricated, and characterized to further study glass compositions that, while broader than the current projections for DWPF feeds with SCIX material, are potential candidates for future processing (i.e., the compositions are acceptable for processing by the PCCS with the exception of the current $\mathrm{TiO}_{2}$ concentration constraint). Several of the KT06-series compositions had durability values that, while acceptable, were not correctly predicted by the current durability models. It was shown that for these high $\mathrm{TiO}_{2}$ concentration glasses, relatively high $\mathrm{Fe}_{2} \mathrm{O}_{3}$ concentrations combined with relatively high $\mathrm{Al}_{2} \mathrm{O}_{3}$ concentrations led to durabilities that were unpredictable. Similar PCT responses (e.g., durability values that are acceptable but not predictable) have been observed in other DWPF studies. Several of the KT06series glasses also had measured viscosity values that were not well predicted by the current model. A statistical partitioning routine showed that the measured viscosities became unpredictable by the current model when the $\mathrm{Fe}_{2} \mathrm{O}_{3}$ concentration in the glasses was less than about $8.2 \mathrm{wt} \%$ and $\mathrm{TiO}_{2}$ concentrations were high. The current durability and viscosity models will have to be further evaluated should compositions in these regions become necessary for DWPF processing. Overall, the results for the KT05 and KT06-series glasses continued to show a reasonable ability to incorporate the anticipated SCIX streams into the DWPF-type glass compositions studied, with $\mathrm{TiO}_{2}$ concentrations of approximately $6 \mathrm{wt} \%$ in glass.

The present report discusses the fabrication and characterization of the KT07-series glass compositions. As will be described below, these glasses were selected to evaluate any potential impacts of noble metals on their properties and performance. The glasses studied thus far for the SCIX work have not included noble metals since they are not typically tracked in sludge batch composition projections. However, noble metals can act as nucleation sites in glass melts, leading to enhanced crystallization. This crystallization can potentially influence the properties and performance of the glass, such as chemical durability, viscosity, and liquidus temperature. 
SRNL-STI-2010-00759

Revision 0

\subsection{Experimental Procedure}

\subsection{Selection of Glass Compositions}

The KT07-series glass compositions were selected in order to evaluate any potential impacts of the inclusion of noble metals, along with the anticipated SCIX streams, on the properties and performance of simulated DWPF glasses. A set of glass compositions developed earlier in this study, the KT04-series, was used as the basis for the current work. The process of selecting the KT04-series glasses is described in detail elsewhere. ${ }^{5}$ In brief, recent projections of Sludge Batches 8 through 17 were used, including anticipated material from SCIX and the SWPF, and with CST being added to Tank 40. An accelerated DWPF production rate was assumed, and the final Sludge Receipt and Adjustment Tank (SRAT) batch for each sludge batch was used since the final SRAT batches represent the highest concentrations of CST. Each of these ten sludge batch projections was combined with a frit that provided a PCCS Measurement Acceptability Region (MAR) acceptable glass composition (with the exception of the $\mathrm{TiO}_{2}$ concentration constraint) at $40 \%$ waste loading. For the KT07-series glasses, $\mathrm{ThO}_{2}$ and $\mathrm{U}_{3} \mathrm{O}_{8}$ were removed from these glass compositions and the noble metals $\mathrm{Ag}, \mathrm{Pd}, \mathrm{Rh}$, and $\mathrm{Ru}$ were added, followed by a normalization of the remaining components to $100 \mathrm{wt} \%$. The noble metals are not typically tracked in sludge batch projections, and were therefore not included in the KT04-series glasses. The concentrations of these metals were obtained from recent measurements of Sludge Batch 6, which was considered to contain a high concentration of noble metals. ${ }^{8}$ The target concentrations for these metals in glass are given in Table 2-1. The resulting target compositions for the KT07series glasses, as oxides, are given in Table 2-2.

Table 2-1. Target Noble Metals Concentrations (in Glass) for the KT07-Series Glasses.

\begin{tabular}{|c|c|}
\hline Metal & (wt \%) \\
\hline $\mathrm{Ag}$ & 0.015 \\
\hline $\mathrm{Pd}$ & 0.007 \\
\hline $\mathrm{Rh}$ & 0.02 \\
\hline $\mathrm{Ru}$ & 0.11 \\
\hline
\end{tabular}


Table 2-2. Target Compositions for the KT07-Series Glasses.

\begin{tabular}{|c|c|c|c|c|c|c|c|c|c|c|}
\hline Oxides & " KT07-01 & " KT07-02 & " KT07-03 & " KT07-04 & " KT07-05 & " KT07-06 & " KT07-07 & " KT07-08 & " KT07-09 & " KT07-10 \\
\hline $\mathrm{Ag}_{2} \mathrm{O}$ & 0.006 & 0.006 & 0.006 & 0.006 & 0.006 & 0.006 & 0.006 & 0.006 & 0.006 & 0.006 \\
\hline $\mathrm{Al}_{2} \mathrm{O}_{3}$ & 5.737 & 5.131 & 4.435 & 4.914 & 6.805 & 7.228 & 5.620 & 5.011 & 5.460 & 5.609 \\
\hline $\mathrm{B}_{2} \mathrm{O}_{3}$ & 5.999 & 5.999 & 5.999 & 5.999 & 5.999 & 5.999 & 5.999 & 5.999 & 5.999 & 5.999 \\
\hline $\mathrm{BaO}$ & 0.067 & 0.068 & 0.069 & 0.068 & 0.068 & 0.068 & 0.075 & 0.075 & 0.076 & 0.077 \\
\hline $\mathrm{CaO}$ & 0.927 & 0.935 & 0.947 & 0.847 & 0.931 & 0.985 & 0.890 & 0.804 & 0.951 & 0.970 \\
\hline $\mathrm{Ce}_{2} \mathrm{O}_{3}$ & 0.282 & 0.285 & 0.252 & 0.213 & 0.142 & 0.108 & 0.078 & 0.079 & 0.199 & 0.244 \\
\hline $\mathrm{Cr}_{2} \mathrm{O}_{3}$ & 0.088 & 0.089 & 0.090 & 0.088 & 0.133 & 0.134 & 0.147 & 0.099 & 0.099 & 0.101 \\
\hline $\mathrm{CuO}$ & 0.038 & 0.038 & 0.039 & 0.038 & 0.038 & 0.038 & 0.042 & 0.042 & 0.043 & 0.043 \\
\hline $\mathrm{Fe}_{2} \mathrm{O}_{3}$ & 11.971 & 11.423 & 11.391 & 12.027 & 9.554 & 9.017 & 9.378 & 9.131 & 12.289 & 13.576 \\
\hline $\mathrm{K}_{2} \mathrm{O}$ & 0.036 & 0.037 & 0.037 & 0.036 & 0.073 & 0.111 & 0.081 & 0.081 & 0.082 & 0.042 \\
\hline $\mathrm{La}_{2} \mathrm{O}_{3}$ & 0.106 & 0.071 & 0.072 & 0.071 & 0.071 & 0.036 & 0.039 & 0.040 & 0.080 & 0.081 \\
\hline $\mathrm{Li}_{2} \mathrm{O}$ & 3.599 & 3.599 & 3.599 & 3.599 & 3.599 & 3.599 & 3.599 & 3.599 & 3.599 & 3.599 \\
\hline $\mathrm{MgO}$ & 0.150 & 0.151 & 0.153 & 0.151 & 0.150 & 0.102 & 0.111 & 0.112 & 0.113 & 0.115 \\
\hline $\mathrm{MnO}$ & 1.906 & 1.687 & 1.788 & 1.055 & 1.015 & 1.186 & 0.735 & 0.960 & 0.570 & 0.403 \\
\hline $\mathrm{Na}_{2} \mathrm{O}$ & 13.101 & 13.950 & 14.230 & 13.671 & 13.631 & 13.645 & 14.508 & 15.411 & 14.023 & 13.505 \\
\hline $\mathrm{Nb}_{2} \mathrm{O}_{5}$ & 1.024 & 1.085 & 1.087 & 1.043 & 1.068 & 1.023 & 1.193 & 1.294 & 0.845 & 0.785 \\
\hline $\mathrm{NiO}$ & 0.345 & 0.193 & 0.313 & 0.154 & 0.115 & 0.156 & 0.639 & 0.602 & 0.519 & 0.485 \\
\hline $\mathrm{PbO}$ & 0.162 & 0.131 & 0.133 & 0.098 & 0.065 & 0.066 & 0.072 & 0.073 & 0.146 & 0.149 \\
\hline $\mathrm{PdO}$ & 0.003 & 0.003 & 0.003 & 0.003 & 0.003 & 0.003 & 0.003 & 0.003 & 0.003 & 0.003 \\
\hline $\mathrm{Rh}_{2} \mathrm{O}_{3}$ & 0.010 & 0.010 & 0.010 & 0.010 & 0.010 & 0.010 & 0.010 & 0.010 & 0.010 & 0.010 \\
\hline $\mathrm{RuO}_{2}$ & 0.058 & 0.058 & 0.058 & 0.058 & 0.058 & 0.058 & 0.058 & 0.058 & 0.058 & 0.058 \\
\hline $\mathrm{SiO}_{2}$ & 48.775 & 49.285 & 49.497 & 50.088 & 50.625 & 50.616 & 50.335 & 50.006 & 48.761 & 48.428 \\
\hline $\mathrm{SO}_{4}{ }^{2-}$ & 0.400 & 0.400 & 0.400 & 0.400 & 0.400 & 0.400 & 0.400 & 0.400 & 0.400 & 0.400 \\
\hline $\mathrm{TiO}_{2}$ & 4.296 & 4.329 & 4.350 & 4.361 & 4.416 & 4.373 & 4.846 & 4.932 & 4.824 & 4.505 \\
\hline $\mathrm{ZnO}$ & 0.000 & 0.038 & 0.038 & 0.075 & 0.038 & 0.076 & 0.083 & 0.042 & 0.042 & 0.043 \\
\hline $\mathrm{ZrO}_{2}$ & 0.913 & 0.999 & 1.004 & 0.927 & 0.986 & 0.956 & 1.054 & 1.130 & 0.802 & 0.762 \\
\hline
\end{tabular}




\subsection{Glass Fabrication}

Each of the study glasses was prepared from the proper proportions of reagent-grade metal oxides, carbonates, and boric acid in $200 \mathrm{~g}$ batches. The raw materials were thoroughly mixed and placed into platinum/gold, $250 \mathrm{ml}$ crucibles. The batch was placed into a high-temperature furnace at the melt temperature of $1150{ }^{\circ} \mathrm{C}$. The crucible was removed from the furnace after an isothermal hold for 1 hour. The glass was poured onto a clean, stainless steel plate and allowed to air cool (quench). The glass pour patty was used as a sampling stock for the various property measurements described below.

Approximately $25 \mathrm{~g}$ of each glass was heat-treated to simulate cooling along the centerline of a DWPF-type canister ${ }^{9}$ to gauge the effects of thermal history on the product performance. This cooling schedule is referred to as the CCC heat treatment. Visual observations of both quenched and CCC glasses were documented.

\subsection{X-Ray Diffraction Analysis}

Representative samples of each quenched and CCC glass were submitted to Analytical Development (AD) for X-ray Diffraction (XRD) analysis. Samples were run under conditions providing a detection limit of approximately $0.5 \mathrm{vol} \%$. That is, if crystals (or unincorporated batch material) were present at $0.5 \mathrm{vol} \%$ or greater, the diffractometer would not only be capable of detecting the crystals but would also allow a qualitative determination of the type of crystal(s) present. Otherwise, a characteristically high background signal (amorphous hump) devoid of crystalline peaks indicates that the glass is free of crystallization, suggesting either a completely amorphous product or that the degree of crystallization is below the detection limit.

\subsection{Composition Analysis}

To confirm that the as-fabricated glasses met the target compositions, a representative sample from each quenched glass in the KT07-series was submitted to the Process Science Analytical Laboratory (PSAL) for chemical analysis under the auspices of an analytical plan. ${ }^{10}$ Two dissolution techniques, sodium peroxide fusion (PF) and lithium-metaborate fusion (LM), were used to prepare the glass samples, in duplicate, for analysis. Each of the samples was analyzed, twice for each element of interest, by Inductively Coupled Plasma - Atomic Emission Spectroscopy (ICP-AES). Glass standards (Batch 1) were also intermittently measured to assess the performance of the ICP-AES instrument over the course of these analyses.

\subsection{Product Consistency Test}

The Product Consistency Test (PCT) Method- $\mathrm{A}^{11}$ was performed in triplicate on each KT07series quenched and CCC glass to assess chemical durability. Also included in the experimental test matrix was the Environmental Assessment (EA) benchmark glass, ${ }^{12}$ the Approved Reference Material (ARM) glass, ${ }^{13}$ and blanks from the sample cleaning batch. Samples were ground, washed, and prepared according to the standard procedure. ${ }^{11}$ Fifteen milliliters of Type-I ASTM water were added to $1.5 \mathrm{~g}$ of glass in stainless steel vessels. The vessels were closed, sealed, and placed in an oven at $90 \pm 2{ }^{\circ} \mathrm{C}$ for 7 days. Once cooled, the resulting solutions were sampled (filtered and acidified), then labeled and analyzed by PSAL under the auspices of an analytical plan. $^{14}$ Samples of a multi-element, standard solution were also included in the analytical plan as a check on the accuracy of the ICP-AES instrument used for these measurements. Normalized release rates were calculated based on the target and measured compositions using the average of the common logarithms of the leachate concentrations. 


\subsection{Viscosity}

The viscosities of the KT07-series glasses were measured following Procedure A of the ASTM C 965 standard. ${ }^{15}$ An Orton high temperature rotating spindle viscometer was used with platinum crucibles and spindles. The crucible and spindle were specially designed to operate with small quantities of glass to support measurements of radioactive glasses when necessary. ${ }^{16,17}$ A well characterized standard glass was used to determine the appropriate spindle constants..$^{17,18}$ Measurements were taken over a range of temperatures from 1050 to $1250{ }^{\circ} \mathrm{C}$ in $50{ }^{\circ} \mathrm{C}$ intervals. Measurements at $1150^{\circ} \mathrm{C}$ were taken at three different times during the procedure to provide an opportunity to identify the effects of any crystallization or volatilization that may have occurred during the test. The data were fit to a Fulcher equation ${ }^{19,20}$ to provide a measured viscosity value at the nominal DWPF melt temperature of $1150^{\circ} \mathrm{C}$.

\subsection{Liquidus Temperature}

Measurements of the liquidus temperatures $\left(\mathrm{T}_{\mathrm{L}}\right)$ of the KT07-series glasses are underway at the time of this report. The data will be reported separately when the measurements are complete.

\subsection{Results and Discussion}

\subsection{Homogeneity}

The homogeneity of each glass sample was assessed via visual observations and XRD. Visual observations of the quenched versions of the KT07-series glasses identified no visible crystallization. All of the quenched glasses were also XRD amorphous. Minor surface crystallization was visible on the CCC versions of glasses KT07-01, -02, $-03,-07,-09$, and -10 , although the bulk of these samples appeared to have remained amorphous. All of the CCC glasses were XRD amorphous, indicating that the volume fraction of the visible surface crystallization was very small.

\subsection{Chemical Composition}

In this section, the measured versus targeted compositions of the study glasses are presented and compared. Measurements for samples of the Batch 1 standard glass that were included in the analytical plan along with the study glasses are also discussed. The elemental concentrations were converted to oxide concentrations by multiplying the values for each element by the gravimetric factor for the corresponding oxide. During this process, an elemental concentration that was determined to be below the detection limit of the analytical procedures used was reduced to half of that detection limit as the oxide concentration was determined. In the discussion that follows, the analytical sequences of the measurements are explored, the measurements of the standard are investigated, the measurements for each glass are reviewed, the average chemical compositions for each glass are determined, and comparisons are made between the measurements and the targeted compositions of the glasses.

Table A-1 and Table A-2 in Appendix A provide the elemental concentration measurements from the KT07 glasses that were prepared using LM, and Table A-3 in Appendix A provides the measurements from the samples of these glasses prepared using PF. Measurements for samples of the standard Batch 1 glass that were included in the analytical plan along with the study glasses are also provided in these tables. Exhibit A-1 in Appendix A provides plots of the sample measurements generated by PSAL for each oxide over both preparation methods. The plots are in analytical sequence with different symbols and colors being used to represent each of the study glasses and the standard glass. In general, there do not appear to be any gross patterns or trends due to the analytical sequence. Further opportunity for a review of the measurements for each glass is provided in the discussions that follow. 
Exhibit A-2 in Appendix A provides plots of the oxide concentration measurements by Glass ID (including the Batch 1 standard) by analytical solution or Lab ID for both preparation methods for the KT07-series. The different symbols and colors being used to represent the glasses are discernable in this exhibit. These plots show the individual measurements across the duplicates of each preparation method and the two ICP-AES calibrations for each glass for each oxide. The results are grouped by analytical block and arranged by targeted concentration to facilitate the interpretation of the measurements. A review of the plots presented in this exhibit reveals the repeatability of the four individual values for each oxide for each glass. There appears to be good repeatability of these measurements for each of the oxides for each of the glasses. There may be a minor preparation issue for the $\mathrm{Cr}_{2} \mathrm{O}_{3}$ measurements for glass KT07-03. There is some scatter in the $\mathrm{B}_{2} \mathrm{O}_{3}, \mathrm{Li}_{2} \mathrm{O}, \mathrm{Na}_{2} \mathrm{O}$, and $\mathrm{SiO}_{2}$ measurements for several of the KT07 glasses. Overall, the data suggest no significant issues with the batching of the KT07 glasses or with the analytical process used to provide representative measurements of their compositions.

Exhibit A-3 in Appendix A provides statistical analyses of the results for the Batch 1 standard that was included with the KT07 glasses by analytical block/sub-block for each oxide of interest over both preparation methods. The results include analysis of variance (ANOVA) investigations looking for statistically significant differences among the means of these groups for each of the oxides. The reference values for the oxide concentrations of the standard are given in the header for each set of measurements in the exhibit. The results from the statistical tests for the Batch 1 standard included with the $\mathrm{KT} 07$ glasses may be summarized as follows: $\mathrm{B}_{2} \mathrm{O}_{3}, \mathrm{BaO}, \mathrm{CaO}, \mathrm{Cr}_{2} \mathrm{O}_{3}$, $\mathrm{K}_{2} \mathrm{O}, \mathrm{MgO}, \mathrm{Na}_{2} \mathrm{O}, \mathrm{NiO}$, and $\mathrm{TiO}_{2}$ have measurements that indicate an ICP-AES calibration effect on the block averages at the $5 \%$ significance level. While statistically significant, the practical impact of these calibration effects is minimal.

All of the measurements for each oxide for each KT07 glass (i.e., all of the measurements in Appendix A Table A-1, Table A-2, and Table A-3) were averaged to determine a representative chemical composition for each glass. A sum of oxides was also computed for each glass based upon the measured values. Exhibit A-4 in Appendix A provides plots showing results for each glass for each oxide to help highlight the comparisons among the measured and targeted values. Some observations from the plots of Exhibit A-4 are offered: Some of the measured $\mathrm{Al}_{2} \mathrm{O}_{3}$ values are slightly above the targets. There is minor scatter in the $\mathrm{B}_{2} \mathrm{O}_{3}, \mathrm{Na}_{2} \mathrm{O}$, and $\mathrm{ZnO}$ measurements. The measured values of $\mathrm{BaO}, \mathrm{La}_{2} \mathrm{O}_{3}$, and $\mathrm{Li}_{2} \mathrm{O}$ are slightly low for all of the glasses. All of the $\mathrm{CaO}$ and $\mathrm{Cr}_{2} \mathrm{O}_{3}$ measurements are slightly above the target values. Some of the measured $\mathrm{Fe}_{2} \mathrm{O}_{3}$, $\mathrm{Nb}_{2} \mathrm{O}_{5}, \mathrm{PbO}, \mathrm{SO}_{4}$, and $\mathrm{ZrO}_{2}$ values are slightly low. The $\mathrm{SiO}_{2}$ values and the sums of oxides are low for all of the study glasses and the Batch 1 standard. In general, there were only minor difficulties in meeting the targeted concentrations for the KT07 glasses, none of which will impact the outcome of the study.

Table A-4 in Appendix A provides a summary of the average measured compositions as well as the targeted compositions and the associated differences and relative differences. Note that the targeted sum of oxides for the Batch 1 standard does not sum to $100 \%$ due to an incomplete coverage of the oxides in this glass. All of the sums of oxides for the KT07 glasses fall within the PCCS acceptable interval of 95 to $105 \mathrm{wt} \%$. Entries in Table A-4 show the relative differences between the measured values and the targeted values. These differences are shaded when they are greater than or equal to 5\%. Overall, these comparisons between the measured and targeted compositions again suggest only minor difficulties in meeting the targeted compositions for the KT07 glasses. A MAR assessment using the measured compositions of the KT07 glasses showed that each composition was PCCS acceptable except for the current $\mathrm{TiO}_{2}$ concentration constraint. 


\subsection{Durability}

The measurements generated by the PCTs are presented and reviewed in this section. The analytical sequence of the measurements is explored, the measurements of the standards are investigated and used to assess the overall accuracy of the ICP-AES measurement process, the measurements for each glass are reviewed, plots are provided that explore the effects of heat treatment on the PCTs for these glasses, the PCTs are normalized using the compositions (targeted and measured) discussed in Section 3.2, and the normalized PCTs are compared to durability predictions for these compositions generated from the current DWPF models. ${ }^{3}$

One of the quality control checkpoints for the PCT procedure is solution mass loss over the course of the seven day test. The third replicate vessel for glass KT07-06 was found to have a solution mass loss issue at the completion of the PCT. Data from this vessel were excluded from further analyses; therefore the results of the PCT for glass KT07-06 are based on only two replicate vessels. There were no issues with solution mass loss for the other vessels in the PCT. The ratio of leachant volume to the mass of ground glass was also confirmed to be correct for each vessel. All of the measurements of the ARM glass fell within the control ranges. ${ }^{13}$

Table B-1 in Appendix B provides the elemental leachate concentration measurements determined by the PSAL for the solution samples generated by the PCTs for the KT07 glasses. The values were adjusted for the dilution factors: the values for the study glasses, the blanks, and the ARM glass in Table B-1 were multiplied by 1.6667 to determine the values in parts per million and the values for EA were multiplied by 16.6667. Table B-1 also provides the resulting ppm measurements.

Exhibit B-1 in Appendix B provides plots of the leachate (ppm) concentrations in analytical sequence as generated by the PSAL for all of the data from the KT07 PCTs. Different colors and symbols are used for each of the study glasses and standards. No issues are seen in these plots.

Exhibit B-2 in Appendix B provides analyses of the PSAL measurements of the samples of the multi-element standard solution by analytical set and ICP-AES calibration block for the KT07series. An ANOVA investigating for statistically significant differences among the block averages for these samples for each element of interest is included in the exhibit. A statistically significant (at a 5\% level) difference among the averages of these measurements was indicated for $\mathrm{B}$ and $\mathrm{Li}$. However, no attempt was made to bias correct for these effects since averaging the measured concentrations for each set of triplicates in the PCT helps to minimize the impact of any potential ICP-AES bias effects. Table 3-1 summarizes the average measurements and the reference values for the four elements of interest in the multi-element standard solution. The results indicate consistent and accurate measurements from the PSAL processes used to conduct these analyses. 
SRNL-STI-2010-00759

Revision 0

Table 3-1. Results form Samples of the Multi-Element Solution Standard.

\begin{tabular}{|c|c|c|c|c|c||}
\hline Block & $\begin{array}{c}\text { Number of } \\
\text { Measurements }\end{array}$ & $\begin{array}{c}\text { Mean } \\
(\mathbf{B}(\mathbf{p p m}))\end{array}$ & $\begin{array}{c}\text { Mean } \\
(\mathbf{L i}(\mathbf{p p m}))\end{array}$ & $\begin{array}{c}\text { Mean } \\
(\mathbf{N a}(\mathbf{p p m}))\end{array}$ & $\begin{array}{c}\text { Mean } \\
(\mathbf{S i}(\mathbf{p p m}))\end{array}$ \\
\hline 1 & 3 & 21.3 & 10.4 & 85.1 & 50.6 \\
\hline 2 & 3 & 19.8 & 10.1 & 84.9 & 49.4 \\
\hline 3 & 3 & 20.1 & 10.0 & 84.1 & 49.4 \\
\hline \multicolumn{6}{|c|}{} \\
\hline \multicolumn{7}{|c|}{ Grand Average } & 20.4 & 10.2 & 84.7 & 49.8 \\
\hline Reference Value & 20 & 10 & 81 & 50 \\
\hline Percent Difference & 2.0 & 1.7 & 4.6 & -0.4 \\
\hline \hline
\end{tabular}

Exhibit B-3 in Appendix B provides plots of the leachate concentrations for each type of submitted sample: the study glasses by heat treatment and the standards (EA, ARM, the multielement solution standard, and blanks). The common logarithm plots allow for the assessment of the repeatability of the measurements, which suggest only minor scatter in the triplicate values for some analytes for some of the glasses. Note that the measurements for one of the replicates of glass KT07-06 (Lab ID h57), which was excluded from the analysis due to solution mass loss as discussed earlier, is denoted by a ( $\mathbf{a})$ symbol in this and these following plots in Appendix B.

The PCT leachate concentrations were normalized using the target and measured cation compositions of the glasses to obtain $\mathrm{g} / \mathrm{L}$ leachate concentrations following the procedure. ${ }^{11}$ Exhibit B-4 in Appendix B provides scatter plots for these results and offers an opportunity to investigate the consistency in the leaching across the elements for the KT07 glasses. All combinations of the normalizations of the PCTs (i.e., those generated using the targeted and measured compositional views) and both heat treatments are represented in the series of scatter plots. Consistency in the leaching across the elements is typically demonstrated by a high degree of linear correlation among the values for pairs of these elements. The smallest correlation in this plot is that for B and $\mathrm{Si}$ with a value of $\sim 98 \%$, indicating highly linear correlations for all of the element pairs.

Table B-2 in Appendix B summarizes the normalized PCTs for the KT07-series glasses. The PCTs are listed by heat treatment and compositional view for each glass. The KT07 glasses all had NL [B] values that were well below the $16.695 \mathrm{~g} / \mathrm{L}$ value of the benchmark EA glass. The highest NL [B] value was for glass KT07-09, with values of $0.618 \mathrm{~g} / \mathrm{L}$ and $0.565 \mathrm{~g} / \mathrm{L}$ for the quenched and $\mathrm{CCC}$ versions of this glass, respectively, normalized to the measured composition.

Exhibit B-5 in Appendix B provides plots showing comparisons of the normalized PCT responses for the two heat treatments for each glass. A review of these plots shows only minor differences in normalized release for the KT07 glasses as a function of heat treatment.

The predictability of the KT07 PCT responses was evaluated using the DWPF durability models. The predicted PCT values, determined using the targeted and measured compositions of the KT07 glasses, were compared with the normalized PCT responses. Exhibit B-6 in Appendix B provides plots of the DWPF models for $\mathrm{B}, \mathrm{Li}, \mathrm{Na}$, and $\mathrm{Si}$ that relate the logarithm of the normalized PCT value (for each element of interest) to a linear function of a free energy of hydration term $\left(\Delta G_{p}\right.$, in $\mathrm{kcal} / 100 \mathrm{~g}$ glass) derived from all of the compositional views and heat treatments of the KT07 glasses. Prediction limits at a 95\% confidence for an individual PCT result are also plotted along with the linear fit. The EA and ARM results are indicated on these plots as well. The plots show 
that all of the measured PCT responses for the KT07-series glasses are well predicted by the current DWPF PCCS durability models.

\subsection{Viscosity}

Viscosity data were collected for all of the glasses in the KT07-series. The measured viscosity at $1150{ }^{\circ} \mathrm{C}$ was determined by fitting the data for each glass to the Fulcher equation. ${ }^{19,20}$ Complete data from the fitting of Fulcher equations are given in Exhibit C-1 in Appendix C. The results of the Fulcher fits of the measured data were used to calculate a viscosity value for each glass at $1150{ }^{\circ} \mathrm{C}$. These values are given in Table C-1 in Appendix C. The measured values are displayed graphically versus the model predictions in Exhibit C-2 in Appendix C. The table and plot show that all of the measured viscosity values for the KT07-series glasses at $1150{ }^{\circ} \mathrm{C}$ are predictable by the current DWPF PCCS viscosity model.

\subsection{Summary}

This report discusses the fabrication and characterization of the KT07-series glass compositions. These glasses were selected to evaluate any potential impacts of noble metals on their properties and performance. The glasses characterized thus far for the study of potential impacts of the SCIX streams on DWPF glass have not included noble metals since they are not typically tracked in sludge batch composition projections. However, noble metals can act as nucleation sites in glass melts, leading to enhanced crystallization. This crystallization can potentially influence the properties and performance of the glass, such as chemical durability, viscosity, and liquidus temperature. A set of glass compositions developed earlier in the SCIX study, the KT04-series, was used as the basis for the current work. For the KT07-series glasses, the noble metals Ag, Pd, $\mathrm{Rh}$, and $\mathrm{Ru}$ were added. The concentrations of these metals were obtained from recent measurements of Sludge Batch 6, which was considered to contain a high concentration of noble metals. $^{8}$

After fabrication, the glasses were characterized to determine their crystalline content, chemical composition, durability, and viscosity. Liquidus temperature measurements are also underway but were not complete at the time of this report. The liquidus temperature results for the KT07series glasses, along with several of the earlier glasses in the SCIX study, will be documented separately. All of the KT07-series glasses, both quenched and slowly cooled, were found to be amorphous by XRD. Chemical composition measurements showed that all of the glasses met their targeted compositions. The PCT results showed that all of the glasses had chemical durabilities that were far better than that of the EA benchmark glass. The measured PCT responses were well predicted by the current DWPF PCCS durability models. The measured viscosity values for each KT07-series glass were acceptable for DWPF processing and were well predicted by the current PCCS model.

Overall, the results show that the inclusion of relatively high concentrations of noble metals (in terms of expected values for a DWPF sludge batch) had no significant impact on the properties and performance of these glass compositions. The lack of crystallization in the KT07-series glasses, their measured PCT responses, and their measured viscosity values are very consistent with the KT04-series glasses, which did not contain noble metals. As previously mentioned, liquidus temperature measurements are still underway and there may be an impact of the noble metals on those measurements. However, no adverse effects were noted in terms of crystallization after slow cooling. 


\subsection{Recommendations and Path Forward}

Liquidus temperature measurements for the KT07 and other KT-series glass compositions will continue, and the results will be presented in a separate technical report. The potential impacts of $\mathrm{ThO}_{2}$ and $\mathrm{U}_{3} \mathrm{O}_{8}$ (as well as noble metals) on the properties and performance of glasses with increased $\mathrm{TiO}_{2}$ concentrations will be investigated through the KT08-series glasses. The KT08series glasses have been fabricated and characterization is now underway. A series of glasses designated KT09 will be fabricated and characterized to identify the potential influence of increased $\mathrm{Al}_{2} \mathrm{O}_{3}$ and $\mathrm{K}_{2} \mathrm{O}$ concentrations on hindering the formation of titanium-containing crystalline phases. An additional series of glasses, KT10, will be fabricated to investigate the impacts of an increase of MST and CST over the current projected maximum concentrations using non-radioactive glasses.

At the completion of these studies, all of the data generated will be reviewed with regard to the applicability of the DWPF PCCS models and recommendations will be made as to whether the validation ranges of the current models can be extended, or whether some or all of the models need to be refit to allow for the incorporation of the SCIX streams. As changes are made to the projected sludge compositions and the volume of the SCIX material, additional evaluations should be performed.

\subsection{References}

1. Fellinger, T. L., "Technical Task Request: DWPF Glass Evaluation for the Introduction of MSP Products into Future Sludge Batches," U.S. Department of Energy Report HLW-DWPFTTR-2010-0009, Revision A, Savannah River Remediation, Aiken, SC (2010).

2. Fox, K. M., "Task Technical and Quality Assurance Plan for Evaluation of the Introduction of Modular Salt Processing Products to Defense Waste Processing Facility Glass for Future Sludge Batches," U.S. Department of Energy Report SRNL-RP-2010-00560, Revision 0, Savannah River National Laboratory, Aiken, SC (2010).

3. Edwards, T. B., K. G. Brown and R. L. Postles, "SME Acceptability Determination for DWPF Process Control," U.S. Department of Energy Report WSRC-TR-95-00364, Revision 5, Washington Savannah River Company, Aiken, SC (2006).

4. Fox, K. M., T. B. Edwards, M. E. Stone and D. C. Koopman, "Paper Study Evaluations of the Introduction of Small Column Ion Exchange (SCIX) Waste Streams to the Defense Waste Processing Facility," U.S. Department of Energy Report SRNL-STI-2010-00297, Revision 0, Savannah River National Laboratory, Aiken, SC (2010).

5. Fox, K. M. and T. B. Edwards, "Impacts of Small Column Ion Exchange Streams on DWPF Glass Formulation: KT01, KT02, KT03, and KT04-Series Glass Compositions," U.S. Department of Energy Report SRNL-STI-2010-00566, Revision 0, Savannah River National Laboratory, Aiken, $\mathrm{SC}(2010)$.

6. Fox, K. M. and T. B. Edwards, "Impacts of Small Column Ion Exchange Streams on DWPF Glass Formulation: KT05 and KT06-Series Glass Compositions," U.S. Department of Energy Report SRNL-STI-2010-00687, Revision 0, Savannah River National Laboratory, Aiken, SC (2010). 
7. Johnson, F. C. and T. B. Edwards, "Results of the FY09 Enhanced DOE High-Level Waste Melter Throughput Studies at SRNL," U.S. Department of Energy Report SRNL-STI-2009-00778, Revision 0, Savannah River National Laboratory, Aiken, SC (2010).

8. Lambert, D. P. and A. S. Choi, "DWPF Coal-Carbon Waste Acceptance Criteria Limit Evaluation Based on Experimental Work (Tank 48 Impact Study)," U.S. Department of Energy Report SRNL-STI-2010-00589, Revision 0, Savannah River National Laboratory, Aiken, SC (2010).

9. Marra, S. L. and C. M. Jantzen, "Characterization of Projected DWPF Glass Heat Treated to Simulate Canister Centerline Cooling," U.S. Department of Energy Report WSRC-TR-92-142, Revision 1, Westinghouse Savannah River Company, Aiken, SC (1993).

10. Edwards, T. B., "An Analytical Plan for Measuring the Chemical Compositions of the KT07Series of Glasses from the Study of the Impact of SCIX Streams on DWPF Wasteforms," U.S. Department of Energy Memorandum SRNL-L5200-2010-000039, Savannah River National Laboratory, Aiken, SC (2010).

11. ASTM, "Standard Test Methods for Determining Chemical Durability of Nuclear Waste Glasses: The Product Consistency Test (PCT)," ASTM C-1285, (2002).

12. Jantzen, C. M., N. E. Bibler, D. C. Beam, C. L. Crawford and M. A. Pickett, "Characterization of the Defense Waste Processing Facility (DWPF) Environmental Assessment (EA) Glass Standard Reference Material," U.S. Department of Energy Report WSRC-TR-92-346, Revision 1, Westinghouse Savannah River Company, Aiken, SC (1993).

13. Jantzen, C. M., J. B. Picket, K. G. Brown, T. B. Edwards and D. C. Beam, "Process/Product Models for the Defense Waste Processing Facility (DWPF): Part I. Predicting Glass Durability from Composition Using a Thermodynamic Hydration Energy Reaction Model (THERMO)," U.S. Department of Energy Report WSRC-TR-93-672, Revision 1, Westinghouse Savannah River Company, Aiken, SC (1995).

14. Edwards, T. B., "An Analytical Plan for Measuring the PCT Solutions of the KT07 Series of Glasses from the Study of the Impact of SCIX Streams on DWPF Wasteforms," U.S. Department of Energy Memorandum SRNL-L5200-2010-00040, Savannah River National Laboratory, Aiken, SC (2010).

15. ASTM, "Standard Practice for Measuring Viscosity of Glass Above the Softening Point," ASTM C-965, (2007).

16. Schumacher, R. F. and D. K. Peeler, "Establishment of Harrop, High-Temperature Viscometer," U.S. Department of Energy Report WSRC-RP-98-00737, Revision 0, Westinghouse Savannah River Company, Aiken, SC (1998).

17. Schumacher, R. F., R. J. Workman and T. B. Edwards, "Calibration and Measurement of the Viscosity of DWPF Start-Up Glass," U.S. Department of Energy Report WSRC-RP-2000-00874, Revision 0, Westinghouse Savannah River Company, Aiken, SC (2001).

18. Crum, J. V., R. L. Russell, M. J. Schweiger, D. E. Smith, J. D. Vienna, T. B. Edwards, C. M. Jantzen, D. K. Peeler, R. F. Schumacher and R. J. Workman, "DWPF Startup Frit Viscosity Measurement Round Robin Results," Pacific Northwest National Laboratory, (Unpublished). 
19. Fulcher, G. S., "Analysis of Recent Measurements of the Viscosity of Glasses," Journal of the American Ceramic Society, 8 [6] 339-355 (1925).

20. Fulcher, G. S., “Analysis of Recent Measurements of the Viscosity of Glasses, II," Journal of the American Ceramic Society, 8 [12] 789-794 (1925). 
SRNL-STI-2010-00759

Revision 0

Appendix A. Data Supporting the Chemical Composition Measurements of the KT07-Series Glasses 
SRNL-STI-2010-00759

Revision 0

Table A-1. PSAL Chemical Composition Measurements of the KT07-Series of Glasses Using LM Preparation Method. (part 1)

\begin{tabular}{|c|c|c|c|c|c|c|c|c|c|c|c|c|c|c|c|c|}
\hline $\begin{array}{c}\text { Glass } \\
\text { ID }\end{array}$ & Block & $\begin{array}{c}\text { Sub- } \\
\text { Blk }\end{array}$ & Seq & Lab ID & $\begin{array}{c}\text { Ag } \\
\text { (wt \%) }\end{array}$ & $\begin{array}{c}\mathrm{Al} \\
(\mathrm{wt} \%)\end{array}$ & $\begin{array}{c}\text { Ba } \\
\text { (wt\%) }\end{array}$ & $\begin{array}{c}\mathrm{Ca} \\
(\mathrm{wt} \%)\end{array}$ & $\begin{array}{c}\mathrm{Ce} \\
(\mathrm{wt} \%)\end{array}$ & $\begin{array}{c}\mathrm{Cr} \\
(\mathbf{w t} \%)\end{array}$ & $\begin{array}{c}\mathrm{Cu} \\
(\mathrm{wt} \%)\end{array}$ & $\begin{array}{c}\mathbf{F e} \\
(\mathrm{wt} \%)\end{array}$ & $\begin{array}{c}\mathrm{K} \\
(\mathrm{wt} \%)\end{array}$ & $\begin{array}{c}\text { La } \\
(\mathrm{wt} \%)\end{array}$ & $\begin{array}{c}\text { Mg } \\
\text { (wt\%) }\end{array}$ & $\begin{array}{c}\text { Mn } \\
\text { (wt\%) }\end{array}$ \\
\hline Batch 1 & 1 & 1 & 1 & BCHLM111 & $<0.100$ & 2.51 & 0.126 & 0.962 & $<0.010$ & 0.073 & 0.314 & 8.72 & 2.61 & $<0.010$ & 0.830 & 1.33 \\
\hline KT07-09 & 1 & 1 & 2 & G10LM21 & $<0.100$ & 2.94 & 0.058 & 0.688 & 0.155 & 0.071 & 0.028 & 8.33 & 0.073 & 0.050 & 0.061 & 0.427 \\
\hline KT07-07 & 1 & 1 & 3 & G04LM11 & $<0.100$ & 3.01 & 0.062 & 0.639 & 0.066 & 0.105 & 0.046 & 6.44 & 0.059 & 0.022 & 0.065 & 0.557 \\
\hline KT07-08 & 1 & 1 & 4 & G02LM11 & $<0.100$ & 2.67 & 0.064 & 0.677 & 0.068 & 0.073 & 0.034 & 6.32 & 0.057 & 0.025 & 0.068 & 0.740 \\
\hline KT07-03 & 1 & 1 & 5 & G03LM11 & $<0.100$ & 2.44 & 0.057 & 0.712 & 0.210 & 0.091 & 0.032 & 7.85 & 0.025 & 0.050 & 0.090 & 1.41 \\
\hline KT07-06 & 1 & 1 & 6 & G06LM21 & $<0.100$ & 3.87 & 0.054 & 0.699 & 0.093 & 0.093 & 0.033 & 6.30 & 0.096 & 0.022 & 0.057 & 0.916 \\
\hline Batch 1 & 1 & 1 & 7 & BCHLM112 & $<0.100$ & 2.51 & 0.126 & 0.942 & $<0.010$ & 0.072 & 0.313 & 8.85 & 2.56 & $<0.010$ & 0.836 & 1.34 \\
\hline KT07-07 & 1 & 1 & 8 & G04LM21 & $<0.100$ & 3.04 & 0.060 & 0.659 & 0.064 & 0.103 & 0.035 & 6.49 & 0.064 & 0.022 & 0.064 & 0.562 \\
\hline KT07-06 & 1 & 1 & 9 & G06LM11 & $<0.100$ & 3.92 & 0.054 & 0.694 & 0.092 & 0.094 & 0.038 & 6.33 & 0.090 & 0.021 & 0.057 & 0.917 \\
\hline KT07-08 & 1 & 1 & 10 & G02LM21 & $<0.100$ & 2.74 & 0.062 & 0.587 & 0.066 & 0.073 & 0.032 & 6.38 & 0.061 & 0.024 & 0.066 & 0.748 \\
\hline KT07-09 & 1 & 1 & 11 & G10LM11 & $<0.100$ & 2.94 & 0.062 & 0.681 & 0.165 & 0.069 & 0.030 & 8.37 & 0.058 & 0.053 & 0.065 & 0.430 \\
\hline KT07-03 & 1 & 1 & 12 & G03LM21 & $<0.100$ & 2.42 & 0.057 & 0.711 & 0.210 & 0.071 & 0.040 & 7.71 & 0.023 & 0.051 & 0.092 & 1.38 \\
\hline Batch 1 & 1 & 1 & 13 & BCHLM113 & $<0.100$ & 2.50 & 0.125 & 0.931 & $<0.010$ & 0.072 & 0.305 & 8.59 & 2.53 & $<0.010$ & 0.824 & 1.31 \\
\hline Batch 1 & 1 & 2 & 1 & BCHLM121 & $<0.100$ & 2.52 & 0.127 & 0.983 & $<0.010$ & 0.074 & 0.320 & 8.80 & 2.65 & $<0.010$ & 0.823 & 1.33 \\
\hline KT07-06 & 1 & 2 & 2 & G06LM22 & $<0.100$ & 3.93 & 0.056 & 0.738 & 0.094 & 0.096 & 0.036 & 6.36 & 0.105 & 0.023 & 0.060 & 0.924 \\
\hline KT07-06 & 1 & 2 & 3 & G06LM12 & $<0.100$ & 3.92 & 0.056 & 0.736 & 0.097 & 0.096 & 0.042 & 6.46 & 0.101 & 0.024 & 0.060 & 0.932 \\
\hline KT07-03 & 1 & 2 & 4 & G03LM12 & $<0.100$ & 2.36 & 0.058 & 0.736 & 0.216 & 0.092 & 0.035 & 7.92 & 0.028 & 0.052 & 0.093 & 1.41 \\
\hline KT07-07 & 1 & 2 & 5 & G04LM12 & $<0.100$ & 3.02 & 0.063 & 0.647 & 0.068 & 0.108 & 0.048 & 6.57 & 0.061 & 0.023 & 0.067 & 0.564 \\
\hline KT07-08 & 1 & 2 & 6 & G02LM12 & $<0.100$ & 2.66 & 0.066 & 0.679 & 0.070 & 0.076 & 0.036 & 6.34 & 0.058 & 0.026 & 0.071 & 0.739 \\
\hline Batch 1 & 1 & 2 & 7 & BCHLM122 & $<0.100$ & 2.48 & 0.127 & 0.972 & $<0.010$ & 0.074 & 0.316 & 8.84 & 2.64 & $<0.010$ & 0.828 & 1.33 \\
\hline KT07-08 & 1 & 2 & 8 & G02LM22 & $<0.100$ & 2.71 & 0.064 & 0.624 & 0.067 & 0.075 & 0.035 & 6.49 & 0.068 & 0.025 & 0.069 & 0.755 \\
\hline KT07-09 & 1 & 2 & 9 & G10LM22 & $<0.100$ & 2.92 & 0.062 & 0.753 & 0.167 & 0.077 & 0.035 & 8.52 & 0.078 & 0.054 & 0.065 & 0.434 \\
\hline KT07-03 & 1 & 2 & 10 & G03LM22 & $<0.100$ & 2.38 & 0.059 & 0.765 & 0.221 & 0.074 & 0.045 & 7.87 & 0.028 & 0.053 & 0.096 & 1.40 \\
\hline KT07-09 & 1 & 2 & 11 & G10LM12 & $<0.100$ & 2.87 & 0.065 & 0.743 & 0.177 & 0.074 & 0.036 & 8.50 & 0.067 & 0.056 & 0.069 & 0.431 \\
\hline KT07-07 & 1 & 2 & 12 & G04LM22 & $<0.100$ & 2.93 & 0.062 & 0.718 & 0.067 & 0.108 & 0.040 & 6.57 & 0.073 & 0.024 & 0.067 & 0.561 \\
\hline Batch 1 & 1 & 2 & 13 & BCHLM123 & $<0.100$ & 2.44 & 0.127 & 1.022 & $<0.010$ & 0.075 & 0.330 & 8.82 & 2.76 & $<0.010$ & 0.828 & 1.33 \\
\hline Batch 1 & 2 & 1 & 1 & BCHLM211 & $<0.100$ & 2.50 & 0.124 & 0.989 & $<0.010$ & 0.073 & 0.316 & 8.93 & 2.62 & $<0.010$ & 0.801 & 1.36 \\
\hline KT07-05 & 2 & 1 & 2 & G01LM21 & $<0.100$ & 3.63 & 0.055 & 0.819 & 0.124 & 0.094 & 0.040 & 6.74 & 0.063 & 0.051 & 0.092 & 0.801 \\
\hline KT07-10 & 2 & 1 & 3 & G05LM21 & $<0.100$ & 3.02 & 0.063 & 0.797 & 0.201 & 0.074 & 0.038 & 9.42 & 0.038 & 0.055 & 0.065 & 0.302 \\
\hline KT07-10 & 2 & 1 & 4 & G05LM11 & $<0.100$ & 3.01 & 0.065 & 0.704 & 0.209 & 0.077 & 0.037 & 9.38 & 0.030 & 0.058 & 0.068 & 0.303 \\
\hline KT07-02 & 2 & 1 & 5 & G07LM21 & $<0.100$ & 2.73 & 0.054 & 0.716 & 0.233 & 0.066 & 0.035 & 7.81 & 0.030 & 0.048 & 0.088 & 1.31 \\
\hline KT07-01 & 2 & 1 & 6 & G08LM11 & $<0.100$ & 2.93 & 0.055 & 0.742 & 0.238 & 0.066 & 0.045 & 8.09 & 0.028 & 0.075 & 0.088 & 1.47 \\
\hline Batch 1 & 2 & 1 & 7 & BCHLM212 & $<0.100$ & 2.43 & 0.125 & 0.994 & $<0.010$ & 0.073 & 0.322 & 8.83 & 2.66 & $<0.010$ & 0.809 & 1.34 \\
\hline KT07-01 & 2 & 1 & 8 & G08LM21 & $<0.100$ & 3.08 & 0.057 & 0.714 & 0.250 & 0.067 & 0.044 & 8.30 & 0.026 & 0.078 & 0.091 & 1.52 \\
\hline KT07-05 & 2 & 1 & 9 & G01LM11 & $<0.100$ & 3.74 & 0.057 & 0.753 & 0.129 & 0.095 & 0.041 & 6.75 & 0.057 & 0.052 & 0.095 & 0.805 \\
\hline KT07-04 & 2 & 1 & 10 & G09LM11 & $<0.100$ & 2.82 & 0.057 & 0.651 & 0.191 & 0.065 & 0.037 & 8.45 & 0.023 & 0.051 & 0.091 & 0.845 \\
\hline KT07-02 & 2 & 1 & 11 & G07LM11 & $<0.100$ & 2.96 & 0.055 & 0.696 & 0.245 & 0.067 & 0.039 & 7.93 & 0.028 & 0.049 & 0.090 & 1.35 \\
\hline KT07-04 & 2 & 1 & 12 & G09LM21 & $<0.100$ & 2.70 & 0.054 & 0.668 & 0.183 & 0.062 & 0.037 & 8.36 & 0.028 & 0.048 & 0.087 & 0.834 \\
\hline Batch 1 & 2 & 1 & 13 & BCHLM213 & $<0.100$ & 2.61 & 0.124 & 0.990 & $<0.010$ & 0.073 & 0.318 & 9.02 & 2.63 & $<0.010$ & 0.805 & 1.37 \\
\hline Batch 1 & 2 & 2 & 1 & BCHLM221 & $<0.100$ & 2.50 & 0.126 & 0.957 & $<0.010$ & 0.075 & 0.310 & 8.70 & 2.51 & $<0.010$ & 0.839 & 1.33 \\
\hline KT07-01 & 2 & 2 & 2 & G08LM22 & $<0.100$ & 3.13 & 0.057 & 0.697 & 0.248 & 0.067 & 0.043 & 8.18 & 0.025 & 0.077 & 0.092 & 1.50 \\
\hline KT07-05 & 2 & 2 & 3 & G01LM22 & $<0.100$ & 3.66 & 0.055 & 0.820 & 0.124 & 0.095 & 0.039 & 6.59 & 0.061 & 0.050 & 0.092 & 0.789 \\
\hline KT07-01 & 2 & 2 & 4 & G08LM12 & $<0.100$ & 3.08 & 0.054 & 0.733 & 0.235 & 0.063 & 0.044 & 8.12 & 0.028 & 0.073 & 0.086 & 1.49 \\
\hline KT07-10 & 2 & 2 & 5 & G05LM12 & $<0.100$ & 2.99 & 0.064 & 0.715 & 0.209 & 0.076 & 0.037 & 9.17 & 0.031 & 0.056 & 0.066 & 0.304 \\
\hline KT07-02 & 2 & 2 & 6 & G07LM22 & $<0.100$ & 2.78 & 0.053 & 0.719 & 0.233 & 0.064 & 0.035 & 7.78 & 0.031 & 0.046 & 0.085 & 1.31 \\
\hline Batch 1 & 2 & 2 & 7 & BCHLM222 & $<0.100$ & 2.58 & 0.125 & 0.990 & $<0.010$ & 0.073 & 0.322 & 8.92 & 2.62 & $<0.010$ & 0.815 & 1.36 \\
\hline KT07-04 & 2 & 2 & 8 & G09LM12 & $<0.100$ & 2.74 & 0.056 & 0.638 & 0.189 & 0.065 & 0.037 & 8.10 & 0.024 & 0.050 & 0.091 & 0.819 \\
\hline KT07-05 & 2 & 2 & 9 & G01LM12 & $<0.100$ & 3.84 & 0.057 & 0.746 & 0.127 & 0.096 & 0.041 & 6.66 & 0.055 & 0.051 & 0.096 & 0.801 \\
\hline KT07-04 & 2 & 2 & 10 & G09LM22 & $<0.100$ & 2.73 & 0.055 & 0.655 & 0.182 & 0.064 & 0.037 & 8.22 & 0.026 & 0.048 & 0.090 & 0.828 \\
\hline KT07-10 & 2 & 2 & 11 & G05LM22 & $<0.100$ & 3.17 & 0.064 & 0.783 & 0.201 & 0.075 & 0.038 & 9.39 & 0.036 & 0.055 & 0.066 & 0.309 \\
\hline KT07-02 & 2 & 2 & 12 & G07LM12 & $<0.100$ & 2.87 & 0.056 & 0.671 & 0.242 & 0.068 & 0.039 & 7.83 & 0.025 & 0.048 & 0.092 & 1.33 \\
\hline Batch 1 & 2 & 2 & 13 & BCHLM223 & $<0.100$ & 2.61 & 0.127 & 0.951 & $<0.010$ & 0.074 & 0.312 & 8.05 & 2.52 & $<0.010$ & 0.833 & 1.29 \\
\hline
\end{tabular}


SRNL-STI-2010-00759

Revision 0

Table A-2. PSAL Chemical Composition Measurements of the KT07-Series of Glasses Using LM Preparation Method. (part 2)

\begin{tabular}{|c|c|c|c|c|c|c|c|c|c|c|c|c|c|c|c|c|}
\hline $\begin{array}{l}\text { Glass } \\
\text { ID }\end{array}$ & Block & $\begin{array}{l}\text { Sub- } \\
\text { Blk }\end{array}$ & Seq & Lab ID & $\begin{array}{c}\mathrm{Na} \\
\text { (wt\%) }\end{array}$ & $\begin{array}{c}\mathrm{Nb} \\
(\mathrm{wt} \%)\end{array}$ & $\begin{array}{c}\mathrm{Ni} \\
(\mathrm{wt} \%)\end{array}$ & $\begin{array}{c}\mathbf{P b} \\
\text { (wt\%) }\end{array}$ & \begin{tabular}{|c|} 
Pd \\
(wt \%)
\end{tabular} & $\begin{array}{c}\text { Rh } \\
\text { (wt\%) }\end{array}$ & $\begin{array}{c}\text { Ru } \\
\text { (wt\%) }\end{array}$ & \begin{tabular}{|c|}
$\mathrm{S}$ \\
(wt \%)
\end{tabular} & $\begin{array}{c}\mathrm{Si} \\
(w t \%)\end{array}$ & $\begin{array}{c}\mathbf{T i} \\
\text { (wt\%) }\end{array}$ & \begin{tabular}{|c|}
$\mathrm{Zn}$ \\
(wt\%)
\end{tabular} & $\begin{array}{c}\mathrm{Zr} \\
(\mathrm{wt} \%)\end{array}$ \\
\hline Batch 1 & 1 & 1 & 1 & BCHLM111 & 6.93 & $<0.010$ & 0.548 & $<0.010$ & $<0.010$ & $<0.010$ & $<0.010$ & $<0.100$ & 22.9 & 0.400 & $<0.010$ & 0.064 \\
\hline KT07-09 & 1 & 1 & 2 & G10LM21 & 10.3 & 0.504 & 0.366 & 0.100 & \begin{tabular}{|c|}
$<0.010$ \\
\end{tabular} & $<0.010$ & $<0.010$ & 0.116 & 21.8 & 2.83 & 0.028 & 0.523 \\
\hline KT07-07 & 1 & 1 & 3 & G04LM11 & 10.5 & 0.828 & 0.492 & 0.061 & $<0.010$ & $<0.010$ & $<0.010$ & 0.136 & 22.6 & 2.85 & 0.064 & 0.787 \\
\hline KT07-08 & 1 & 1 & 4 & G02LM11 & 11.1 & 0.903 & 0.470 & 0.063 & $<0.010$ & $<0.010$ & $<0.010$ & 0.126 & 22.4 & 2.90 & 0.035 & 0.823 \\
\hline KT07-03 & 1 & 1 & 5 & G03LM11 & 10.2 & 0.734 & 0.241 & 0.113 & $<0.010$ & $<0.010$ & $<0.010$ & 0.114 & 22.2 & 2.52 & 0.026 & 0.722 \\
\hline KT07-06 & 1 & 1 & 6 & G06LM21 & 9.96 & 0.667 & 0.116 & 0.056 & $<0.010$ & $<0.010$ & $<0.010$ & 0.122 & 22.6 & 2.53 & 0.056 & 0.674 \\
\hline Batch 1 & 1 & 1 & 7 & BCHLM112 & 6.89 & $<0.010$ & 0.546 & $<0.010$ & $<0.010$ & $<0.010$ & $<0.010$ & $<0.100$ & 23.0 & 0.401 & $<0.010$ & 0.066 \\
\hline KT07-07 & 1 & 1 & 8 & G04LM21 & 10.7 & 0.743 & 0.477 & 0.068 & $<0.010$ & $<0.010$ & $<0.010$ & 0.124 & 23.0 & 2.85 & 0.066 & 0.725 \\
\hline KT07-06 & 1 & 1 & 9 & G06LM11 & 10.1 & 0.649 & 0.116 & 0.057 & $<0.010$ & $<0.010$ & $<0.010$ & 0.118 & 22.6 & 2.54 & 0.056 & 0.666 \\
\hline KT07-08 & 1 & 1 & 10 & G02LM21 & 11.4 & 0.872 & 0.452 & 0.060 & $<0.010$ & $<0.010$ & $<0.010$ & 0.121 & 22.8 & 2.95 & 0.030 & 0.794 \\
\hline KT07-09 & 1 & 1 & 11 & G10LM11 & 10.3 & 0.478 & 0.389 & 0.121 & $<0.010$ & $<0.010$ & $<0.010$ & 0.113 & 21.9 & 2.83 & 0.031 & 0.547 \\
\hline KT07-03 & 1 & 1 & 12 & G03LM21 & 10.5 & 0.704 & 0.243 & 0.112 & $<0.010$ & $<0.010$ & $<0.010$ & 0.126 & 22.6 & 2.49 & 0.027 & 0.707 \\
\hline Batch 1 & 1 & 1 & 13 & BCHLM113 & 6.95 & $<0.010$ & 0.544 & $<0.010$ & $<0.010$ & $<0.010$ & $<0.010$ & $<0.100$ & 22.7 & 0.394 & $<0.010$ & 0.066 \\
\hline Batch 1 & 1 & 2 & 1 & BCHLM121 & 6.81 & $<0.010$ & 0.549 & $<0.010$ & $<0.010$ & $<0.010$ & $<0.010$ & $<0.100$ & 23.1 & 0.405 & $<0.010$ & 0.064 \\
\hline KT07-06 & 1 & 2 & 2 & G06LM22 & 9.98 & 0.673 & 0.118 & 0.057 & $<0.010$ & $<0.010$ & $<0.010$ & 0.125 & 23.2 & 2.58 & 0.058 & 0.682 \\
\hline KT07-06 & 1 & 2 & 3 & G06LM12 & 9.97 & 0.658 & 0.118 & 0.057 & \begin{tabular}{|c|}
$<0.010$ \\
\end{tabular} & $<0.010$ & $<0.010$ & 0.130 & 23.1 & 2.59 & 0.058 & 0.678 \\
\hline KT07-03 & 1 & 2 & 4 & G03LM12 & 10.3 & 0.738 & 0.242 & 0.110 & $<0.010$ & $<0.010$ & $<0.010$ & 0.126 & 22.8 & 2.55 & 0.028 & 0.727 \\
\hline KT07-07 & 1 & 2 & 5 & G04LM12 & 10.4 & 0.821 & 0.491 & 0.062 & $<0.010$ & $<0.010$ & $<0.010$ & 0.129 & 23.1 & 2.90 & 0.066 & 0.782 \\
\hline KT07-08 & 1 & 2 & 6 & G02LM12 & 10.8 & 0.905 & 0.475 & 0.065 & \begin{tabular}{|c|}
$<0.010$ \\
\end{tabular} & $<0.010$ & $<0.010$ & 0.136 & 22.6 & 2.91 & 0.037 & 0.836 \\
\hline Batch 1 & 1 & 2 & 7 & BCHLM122 & 6.66 & $<0.010$ & 0.551 & $<0.010$ & $<0.010$ & $<0.010$ & $<0.010$ & $<0.100$ & 23.0 & 0.404 & $<0.010$ & 0.068 \\
\hline KT07-08 & 1 & 2 & 8 & G02LM22 & 11.0 & 0.887 & 0.459 & 0.063 & $<0.010$ & $<0.010$ & $<0.010$ & 0.128 & 22.9 & 2.96 & 0.032 & 0.822 \\
\hline KT07-09 & 1 & 2 & 9 & G10LM22 & 10.1 & 0.526 & 0.376 & 0.114 & $<0.010$ & $<0.010$ & $<0.010$ & 0.126 & 22.0 & 2.87 & 0.032 & 0.556 \\
\hline KT07-03 & 1 & 2 & 10 & G03LM22 & 10.1 & 0.719 & 0.248 & 0.116 & $<0.010$ & $<0.010$ & $<0.010$ & 0.137 & 22.7 & 2.51 & 0.030 & 0.723 \\
\hline KT07-09 & 1 & 2 & 11 & G10LM12 & 9.86 & 0.493 & 0.399 & 0.124 & $<0.010$ & $<0.010$ & $<0.010$ & 0.130 & 22.0 & 2.85 & 0.033 & 0.570 \\
\hline KT07-07 & 1 & 2 & 12 & G04LM22 & 10.0 & 0.765 & 0.486 & 0.069 & $<0.010$ & $<0.010$ & $<0.010$ & 0.130 & 22.8 & 2.85 & 0.069 & 0.749 \\
\hline Batch 1 & 1 & 2 & 13 & BCHLM123 & 6.48 & $<0.010$ & 0.552 & $<0.010$ & $<0.010$ & $<0.010$ & $<0.010$ & $<0.100$ & 22.7 & 0.401 & $\begin{array}{l}<0.010 \\
\end{array}$ & 0.069 \\
\hline Batch 1 & 2 & 1 & 1 & BCHLM211 & 6.59 & $<0.010$ & 0.531 & $<0.010$ & $<0.010$ & $<0.010$ & $<0.010$ & $<0.100$ & 23.0 & 0.417 & \begin{tabular}{|c|}
$<0.010$ \\
\end{tabular} & 0.065 \\
\hline KT07-05 & 2 & 1 & 2 & G01LM21 & 9.69 & 0.712 & 0.086 & 0.054 & $<0.010$ & $<0.010$ & $<0.010$ & 0.122 & 23.0 & 2.58 & 0.043 & 0.717 \\
\hline KT07-10 & 2 & 1 & 3 & G05LM21 & 9.80 & 0.510 & 0.346 & 0.123 & \begin{tabular}{|c|}
$<0.010$ \\
\end{tabular} & $<0.010$ & $<0.010$ & 0.120 & 22.2 & 2.67 & 0.033 & 0.562 \\
\hline KT07-10 & 2 & 1 & 4 & G05Ll & 9.76 & 0.505 & 0.366 & 0.127 & $<0$. & $<0$. & $<0$. & 0.120 & 21.5 & 2.67 & & 0.534 \\
\hline KT07-02 & 2 & 1 & 5 & G07LM21 & 9.99 & 0.687 & 0.137 & 0.105 & $<0.010$ & $<0.010$ & $<0.010$ & 0.127 & 22.1 & 2.52 & 0.029 & 0.689 \\
\hline KT07-01 & 2 & 1 & 6 & G08LM11 & 8.91 & 0.620 & 0.254 & 0.133 & $<0.010$ & $<0.010$ & $<0.010$ & 0.129 & 21.0 & 2.44 & $<0.010$ & 0.631 \\
\hline Batch 1 & 2 & 1 & 7 & BCHLM212 & 6.37 & $<0.010$ & 0.535 & $<0.010$ & $<0.010$ & $<0.010$ & $<0.010$ & $<0.100$ & 22.5 & 0.408 & $<0.010$ & 0.068 \\
\hline KT07-01 & 2 & 1 & 8 & G08LM21 & 9.66 & 0.641 & 0.262 & 0.140 & $<0.010$ & $<0.010$ & $<0.010$ & 0.124 & 21.5 & 2.54 & $<0.010$ & 0.620 \\
\hline KT07-05 & 2 & 1 & 9 & G01LM11 & 9.93 & 0.738 & 0.091 & 0.056 & $<0.010$ & $<0.010$ & $<0.010$ & 0.119 & 23.5 & 2.62 & 0.051 & 0.756 \\
\hline KT07-04 & 2 & 1 & 10 & G09LM11 & 10.2 & 0.653 & 0.119 & 0.085 & $<0.010$ & $<0.010$ & $<0.010$ & 0.127 & 22.8 & 2.66 & 0.057 & 0.657 \\
\hline KT07-02 & 2 & 1 & 11 & G07LM11 & 10.7 & 0.727 & 0.143 & 0.109 & $<0.010$ & $<0.010$ & $<0.010$ & 0.114 & 23.4 & 2.65 & 0.028 & 0.709 \\
\hline KT07-04 & 2 & 1 & 12 & G09LM21 & 9.81 & 0.642 & 0.112 & 0.081 & $<0.010$ & $<0.010$ & $<0.010$ & 0.120 & 22.7 & 2.62 & 0.057 & 0.623 \\
\hline Batch 1 & 2 & 1 & 13 & BCHLM213 & 6.92 & $<0.010$ & 0.531 & $<0.010$ & $<0.010$ & $<0.010$ & $<0.010$ & $<0.100$ & 23.7 & 0.424 & $<0.010$ & 0.068 \\
\hline Batch 1 & 2 & 2 & 1 & BCHLM221 & 6.88 & $<0.010$ & 0.541 & $<0.010$ & $<0.010$ & $<0.010$ & $<0.010$ & $<0.100$ & 22.9 & 0.413 & $<0.010$ & 0.064 \\
\hline KT07-01 & 2 & 2 & 2 & G08LM22 & 9.95 & 0.635 & 0.267 & 0.143 & $<0.010$ & $<0.010$ & $<0.010$ & 0.129 & 21.7 & 2.52 & $<0.010$ & 0.606 \\
\hline KT07-05 & 2 & 2 & 3 & G01LM22 & 10.1 & 0.716 & 0.086 & 0.052 & \begin{tabular}{|c|}
$<0.010$ \\
\end{tabular} & $<0.010$ & $<0.010$ & 0.130 & 23.1 & 2.55 & 0.042 & 0.725 \\
\hline KT07-01 & 2 & 2 & 4 & G08LM12 & 10.1 & 0.616 & 0.251 & 0.130 & $<0.010$ & $<0.010$ & $<0.010$ & 0.115 & 21.8 & 2.50 & $<0.010$ & 0.611 \\
\hline KT07-10 & 2 & 2 & 5 & G05LM12 & 9.98 & 0.507 & 0.365 & 0.124 & $<0.010$ & $<0.010$ & $<0.010$ & 0.119 & 21.4 & 2.63 & 0.029 & 0.532 \\
\hline KT07-02 & 2 & 2 & 6 & G07LM22 & 10.5 & 0.685 & 0.135 & 0.100 & $<0.010$ & $<0.010$ & $<0.010$ & 0.123 & 22.3 & 2.53 & 0.027 & 0.689 \\
\hline Batch 1 & 2 & 2 & 7 & BCHLM222 & 7.15 & $<0.010$ & 0.538 & $<0.010$ & \begin{tabular}{|c|}
$<0.010$ \\
\end{tabular} & $<0.010$ & $<0.010$ & $<0.100$ & 23.7 & 0.421 & \begin{tabular}{|c|}
$<0.010$ \\
\end{tabular} & 0.067 \\
\hline KT07-04 & 2 & 2 & 8 & G09LM12 & 10.5 & 0.656 & 0.119 & 0.085 & $<0.010$ & $<0.010$ & $<0.010$ & 0.129 & 22.2 & 2.58 & 0.056 & 0.653 \\
\hline KT07-05 & 2 & 2 & 9 & G01LM12 & 10.7 & 0.743 & 0.091 & 0.056 & $<0.010$ & $<0.010$ & $<0.010$ & 0.127 & 23.8 & 2.61 & 0.050 & 0.747 \\
\hline KT07-04 & 2 & 2 & 10 & G09LM22 & 10.4 & 0.657 & 0.114 & 0.084 & $<0.010$ & $<0.010$ & $<0.010$ & 0.135 & 22.8 & 2.59 & 0.058 & 0.635 \\
\hline KT07-10 & 2 & 2 & 11 & G05LM22 & 10.6 & 0.520 & 0.356 & 0.125 & $<0.010$ & $<0.010$ & $<0.010$ & 0.119 & 22.9 & 2.71 & 0.033 & 0.570 \\
\hline KT07-02 & 2 & 2 & 12 & G07LM12 & 10.8 & 0.729 & 0.146 & 0.111 & \begin{tabular}{|c|}
$<0.010$ \\
\end{tabular} & $<0.010$ & $<0.010$ & 0.136 & 22.9 & 2.58 & 0.027 & 0.729 \\
\hline Batch 1 & 2 & 2 & 13 & BCHLM223 & 7.16 & $<0.010$ & 0.549 & $<0.010$ & \begin{tabular}{|c|}
$<0.010$ \\
\end{tabular} & $<0.010$ & $<0.010$ & $<0.100$ & 23.0 & 0.408 & \begin{tabular}{|c|}
$<0.010$ \\
\end{tabular} & 0.067 \\
\hline
\end{tabular}


Table A-3. PSAL Chemical Composition Measurements of the KT07-Series of Glasses Using PF Preparation Method.

\begin{tabular}{|c|c|c|c|c|c|c|}
\hline Glass ID & Block & Sub-Blk & Sequence & Lab ID & B (wt\%) & Li (wt\%) \\
\hline Batch 1 & 1 & 1 & 1 & BCHPF111 & 2.59 & 2.05 \\
\hline KT07-10 & 1 & 1 & 2 & G05PF21 & 2.01 & 1.62 \\
\hline KT07-01 & 1 & 1 & 3 & G08PF21 & 1.97 & 1.62 \\
\hline KT07-02 & 1 & 1 & 4 & G07PF21 & 1.94 & 1.61 \\
\hline KT07-02 & 1 & 1 & 5 & G07PF11 & 1.97 & 1.64 \\
\hline KT07-04 & 1 & 1 & 6 & G09PF21 & 1.98 & 1.65 \\
\hline Batch 1 & 1 & 1 & 7 & BCHPF112 & 2.51 & 2.11 \\
\hline KT07-10 & 1 & 1 & 8 & G05PF11 & 2.09 & 1.65 \\
\hline KT07-01 & 1 & 1 & 9 & G08PF11 & 2.04 & 1.65 \\
\hline KT07-03 & 1 & 1 & 10 & G03PF11 & 2.00 & 1.64 \\
\hline KT07-03 & 1 & 1 & 11 & G03PF21 & 1.98 & 1.61 \\
\hline KT07-04 & 1 & 1 & 12 & G09PF11 & 1.98 & 1.63 \\
\hline Batch 1 & 1 & 1 & 13 & BCHPF113 & 2.48 & 2.08 \\
\hline Batch 1 & 1 & 2 & 1 & BCHPF121 & 2.47 & 2.03 \\
\hline KT07-03 & 1 & 2 & 2 & G03PF12 & 1.69 & 1.58 \\
\hline KT07-10 & 1 & 2 & 3 & G05PF12 & 1.76 & 1.60 \\
\hline KT07-04 & 1 & 2 & 4 & G09PF22 & 1.75 & 1.61 \\
\hline KT07-04 & 1 & 2 & 5 & G09PF12 & 1.72 & 1.60 \\
\hline KT07-01 & 1 & 2 & 6 & G08PF22 & 1.71 & 1.59 \\
\hline Batch 1 & 1 & 2 & 7 & BCHPF122 & 2.26 & 2.03 \\
\hline KT07-02 & 1 & 2 & 8 & G07PF22 & 1.84 & 1.55 \\
\hline KT07-03 & 1 & 2 & 9 & G03PF22 & 1.78 & 1.58 \\
\hline KT07-02 & 1 & 2 & 10 & G07PF12 & 1.86 & 1.64 \\
\hline KT07-10 & 1 & 2 & 11 & G05PF22 & 1.74 & 1.60 \\
\hline KT07-01 & 1 & 2 & 12 & G08PF12 & 1.70 & 1.59 \\
\hline Batch 1 & 1 & 2 & 13 & BCHPF123 & 2.31 & 1.99 \\
\hline Batch 1 & 2 & 1 & 1 & BCHPF211 & 2.36 & 1.93 \\
\hline KT07-09 & 2 & 1 & 2 & G10PF21 & 1.85 & 1.53 \\
\hline KT07-05 & 2 & 1 & 3 & G01PF21 & 1.90 & 1.61 \\
\hline KT07-06 & 2 & 1 & 4 & G06PF11 & 1.89 & 1.56 \\
\hline KT07-07 & 2 & 1 & 5 & G04PF21 & 1.88 & 1.58 \\
\hline KT07-07 & 2 & 1 & 6 & G04PF11 & 1.77 & 1.53 \\
\hline Batch 1 & 2 & 1 & 7 & BCHPF212 & 2.32 & 1.96 \\
\hline KT07-08 & 2 & 1 & 8 & G02PF11 & 1.91 & 1.56 \\
\hline KT07-05 & 2 & 1 & 9 & G01PF11 & 1.91 & 1.59 \\
\hline KT07-08 & 2 & 1 & 10 & G02PF21 & 1.87 & 1.62 \\
\hline KT07-09 & 2 & 1 & 11 & G10PF11 & 1.93 & 1.61 \\
\hline KT07-06 & 2 & 1 & 12 & G06PF21 & 1.72 & 1.48 \\
\hline Batch 1 & 2 & 1 & 13 & BCHPF213 & 2.38 & 2.06 \\
\hline Batch 1 & 2 & 2 & 1 & BCHPF221 & 2.49 & 2.05 \\
\hline KT07-08 & 2 & 2 & 2 & G02PF12 & 1.89 & 1.61 \\
\hline KT07-05 & 2 & 2 & 3 & G01PF12 & 1.86 & 1.60 \\
\hline KT07-09 & 2 & 2 & 4 & G10PF22 & 1.82 & 1.59 \\
\hline KT07-07 & 2 & 2 & 5 & G04PF12 & 1.78 & 1.59 \\
\hline KT07-06 & 2 & 2 & 6 & G06PF12 & 1.85 & 1.61 \\
\hline Batch 1 & 2 & 2 & 7 & BCHPF222 & 2.41 & 2.07 \\
\hline KT07-05 & 2 & 2 & 8 & G01PF22 & 1.96 & 1.65 \\
\hline KT07-08 & 2 & 2 & 9 & G02PF22 & 1.87 & 1.60 \\
\hline KT07-09 & 2 & 2 & 10 & G10PF12 & 1.83 & 1.61 \\
\hline KT07-07 & 2 & 2 & 11 & G04PF22 & 1.86 & 1.62 \\
\hline KT07-06 & 2 & 2 & 12 & G06PF22 & 1.67 & 1.47 \\
\hline Batch 1 & 2 & 2 & 13 & BCHPF223 & 2.37 & 2.09 \\
\hline
\end{tabular}


Table A-4. Comparison of Measured versus Targeted Composition for the KT07-Series Glasses.

\begin{tabular}{|c|c|c|c|c|c|}
\hline Glass ID & Oxide & Measured (wt \%) & Targeted (wt \%) & $\begin{array}{c}\text { Difference (wt \%) of } \\
\text { Measured vs Targeted }\end{array}$ & $\begin{array}{c}\text { \% Difference of } \\
\text { Measured vs Targeted }\end{array}$ \\
\hline Batch 1 & $\mathrm{Al}_{2} \mathrm{O}_{3}$ & 4.7537 & 4.8770 & -0.1233 & $-2.5 \%$ \\
\hline Batch 1 & $\mathrm{~B}_{2} \mathrm{O}_{3}$ & 7.7680 & 7.7770 & -0.0090 & $-0.1 \%$ \\
\hline Batch 1 & $\mathrm{BaO}$ & 0.1404 & 0.1510 & -0.0106 & $-7.0 \%$ \\
\hline Batch 1 & $\mathrm{CaO}$ & 1.3622 & 1.2200 & 0.1422 & $11.7 \%$ \\
\hline Batch 1 & $\mathrm{Ce}_{2} \mathrm{O}_{3}$ & 0.0059 & 0.0000 & 0.0059 & \\
\hline Batch 1 & $\mathrm{Cr}_{2} \mathrm{O}_{3}$ & 0.1073 & 0.1070 & 0.0003 & $0.3 \%$ \\
\hline Batch 1 & $\mathrm{CuO}$ & 0.3962 & 0.3990 & -0.0028 & $-0.7 \%$ \\
\hline Batch 1 & $\mathrm{Fe}_{2} \mathrm{O}_{3}$ & 12.5182 & 12.8390 & -0.3208 & $-2.5 \%$ \\
\hline Batch 1 & $\mathrm{~K}_{2} \mathrm{O}$ & 3.1430 & 3.3270 & -0.1840 & $-5.5 \%$ \\
\hline Batch 1 & $\mathrm{La}_{2} \mathrm{O}_{3}$ & 0.0059 & 0.0000 & 0.0059 & \\
\hline Batch 1 & $\mathrm{Li}_{2} \mathrm{O}$ & 4.3865 & 4.4290 & -0.0425 & $-1.0 \%$ \\
\hline Batch 1 & $\mathrm{MgO}$ & 1.3641 & 1.4190 & -0.0549 & $-3.9 \%$ \\
\hline Batch 1 & $\mathrm{MnO}$ & 1.7238 & 1.7260 & -0.0022 & $-0.1 \%$ \\
\hline Batch 1 & $\mathrm{Na}_{2} \mathrm{O}$ & 9.1877 & 9.0030 & 0.1847 & $2.1 \%$ \\
\hline Batch 1 & $\mathrm{Nb}_{2} \mathrm{O}_{5}$ & 0.0072 & 0.0000 & 0.0072 & \\
\hline Batch 1 & $\mathrm{NiO}$ & 0.6909 & 0.7510 & -0.0601 & $-8.0 \%$ \\
\hline Batch 1 & $\mathrm{PbO}$ & 0.0054 & 0.0000 & 0.0054 & \\
\hline Batch 1 & $\mathrm{SiO}_{2}$ & 49.2396 & 50.2200 & -0.9804 & $-2.0 \%$ \\
\hline Batch 1 & $\mathrm{SO}_{4}$ & 0.1498 & 0.0000 & 0.1498 & \\
\hline Batch 1 & $\mathrm{TiO}_{2}$ & 0.6805 & 0.6770 & 0.0035 & $0.5 \%$ \\
\hline Batch 1 & $\mathrm{ZnO}$ & 0.0062 & 0.0000 & 0.0062 & \\
\hline Batch 1 & $\mathrm{ZrO}_{2}$ & 0.0896 & 0.0980 & -0.0084 & $-8.6 \%$ \\
\hline Batch 1 & Sum & 97.7320 & 99.0200 & -1.2880 & $-1.3 \%$ \\
\hline KT07-01 & $\mathrm{Al}_{2} \mathrm{O}_{3}$ & 5.7724 & 5.7370 & 0.0354 & $0.6 \%$ \\
\hline KT07-01 & $\mathrm{B}_{2} \mathrm{O}_{3}$ & 5.9729 & 5.9990 & -0.0261 & $-0.4 \%$ \\
\hline KT07-01 & $\mathrm{BaO}$ & 0.0622 & 0.0670 & -0.0048 & $-7.1 \%$ \\
\hline KT07-01 & $\mathrm{CaO}$ & 1.0095 & 0.9270 & 0.0825 & $8.9 \%$ \\
\hline KT07-01 & $\mathrm{Ce}_{2} \mathrm{O}_{3}$ & 0.2843 & 0.2820 & 0.0023 & $0.8 \%$ \\
\hline KT07-01 & $\mathrm{Cr}_{2} \mathrm{O}_{3}$ & 0.0961 & 0.0880 & 0.0081 & $9.2 \%$ \\
\hline KT07-01 & $\mathrm{CuO}$ & 0.0551 & 0.0380 & 0.0171 & $44.9 \%$ \\
\hline KT07-01 & $\mathrm{Fe}_{2} \mathrm{O}_{3}$ & 11.6842 & 11.9710 & -0.2868 & $-2.4 \%$ \\
\hline KT07-01 & $\mathrm{K}_{2} \mathrm{O}$ & 0.0322 & 0.0360 & -0.0038 & $-10.5 \%$ \\
\hline KT07-01 & $\mathrm{La}_{2} \mathrm{O}_{3}$ & 0.0888 & 0.1060 & -0.0172 & $-16.2 \%$ \\
\hline KT07-01 & $\mathrm{Li}_{2} \mathrm{O}$ & 3.4716 & 3.5990 & -0.1274 & $-3.5 \%$ \\
\hline KT07-01 & $\mathrm{MgO}$ & 0.1480 & 0.1500 & -0.0020 & $-1.3 \%$ \\
\hline KT07-01 & $\mathrm{MnO}$ & 1.9303 & 1.9060 & 0.0243 & $1.3 \%$ \\
\hline KT07-01 & $\mathrm{Na}_{2} \mathrm{O}$ & 13.0149 & 13.1010 & -0.0861 & $-0.7 \%$ \\
\hline KT07-01 & $\mathrm{Nb}_{2} \mathrm{O}_{5}$ & 0.8984 & 1.0240 & -0.1256 & $-12.3 \%$ \\
\hline KT07-01 & $\mathrm{NiO}$ & 0.3289 & 0.3450 & -0.0161 & $-4.7 \%$ \\
\hline KT07-01 & $\mathrm{PbO}$ & 0.1470 & 0.1620 & -0.0150 & $-9.2 \%$ \\
\hline KT07-01 & $\mathrm{SiO}_{2}$ & 45.9950 & 48.7750 & -2.7801 & $-5.7 \%$ \\
\hline KT07-01 & $\mathrm{SO}_{4}$ & 0.3722 & 0.4000 & -0.0278 & $-6.9 \%$ \\
\hline KT07-01 & $\mathrm{TiO}_{2}$ & 4.1700 & 4.2960 & -0.1260 & $-2.9 \%$ \\
\hline KT07-01 & $\mathrm{ZnO}$ & 0.0062 & 0.0000 & 0.0062 & \\
\hline KT07-01 & $\mathrm{ZrO}_{2}$ & 0.8334 & 0.9130 & -0.0796 & $-8.7 \%$ \\
\hline KT07-01 & Sum & 96.3739 & 99.9220 & -3.5481 & $-3.6 \%$ \\
\hline KT07-02 & $\mathrm{Al}_{2} \mathrm{O}_{3}$ & 5.3567 & 5.1310 & 0.2257 & $4.4 \%$ \\
\hline KT07-02 & $\mathrm{B}_{2} \mathrm{O}_{3}$ & 6.1259 & 5.9990 & 0.1269 & $2.1 \%$ \\
\hline KT07-02 & $\mathrm{BaO}$ & 0.0608 & 0.0680 & -0.0072 & $-10.5 \%$ \\
\hline KT07-02 & $\mathrm{CaO}$ & 0.9801 & 0.9350 & 0.0451 & $4.8 \%$ \\
\hline KT07-02 & $\mathrm{Ce}_{2} \mathrm{O}_{3}$ & 0.2791 & 0.2850 & -0.0059 & $-2.1 \%$ \\
\hline KT07-02 & $\mathrm{Cr}_{2} \mathrm{O}_{3}$ & 0.0968 & 0.0890 & 0.0078 & $8.8 \%$ \\
\hline KT07-02 & $\mathrm{CuO}$ & 0.0463 & 0.0380 & 0.0083 & $21.9 \%$ \\
\hline KT07-02 & $\mathrm{Fe}_{2} \mathrm{O}_{3}$ & 11.2053 & 11.4230 & -0.2177 & $-1.9 \%$ \\
\hline KT07-02 & $\mathrm{K}_{2} \mathrm{O}$ & 0.0343 & 0.0370 & -0.0027 & $-7.2 \%$ \\
\hline KT07-02 & $\mathrm{La}_{2} \mathrm{O}_{3}$ & 0.0560 & 0.0710 & -0.0150 & $-21.1 \%$ \\
\hline KT07-02 & $\mathrm{Li}_{2} \mathrm{O}$ & 3.4662 & 3.5990 & -0.1328 & $-3.7 \%$ \\
\hline KT07-02 & $\mathrm{MgO}$ & 0.1472 & 0.1510 & -0.0038 & $-2.5 \%$ \\
\hline KT07-02 & $\mathrm{MnO}$ & 1.7108 & 1.6870 & 0.0238 & $1.4 \%$ \\
\hline
\end{tabular}


Table A-4. Comparison of Measured versus Targeted Composition for the KT07-Series Glasses. (continued)

\begin{tabular}{|c|c|c|c|c|c|}
\hline Glass ID & Oxide & Measured (wt \%) & Targeted (wt \%) & $\begin{array}{c}\text { Difference (wt \%) of } \\
\text { Measured vs Targeted }\end{array}$ & $\begin{array}{c}\text { \% Difference of } \\
\text { Measured vs Targeted }\end{array}$ \\
\hline KT07-02 & $\mathrm{Na}_{2} \mathrm{O}$ & 14.1506 & 13.9500 & 0.2006 & $1.4 \%$ \\
\hline KT07-02 & $\mathrm{Nb}_{2} \mathrm{O}_{5}$ & 1.0114 & 1.0850 & -0.0736 & $-6.8 \%$ \\
\hline KT07-02 & $\mathrm{NiO}$ & 0.1785 & 0.1930 & -0.0145 & $-7.5 \%$ \\
\hline KT07-02 & $\mathrm{PbO}$ & 0.1145 & 0.1310 & -0.0165 & $-12.6 \%$ \\
\hline KT07-02 & $\mathrm{SiO}_{2}$ & 48.5086 & 49.2850 & -0.7764 & $-1.6 \%$ \\
\hline KT07-02 & $\mathrm{SO}_{4}$ & 0.3745 & 0.4000 & -0.0255 & $-6.4 \%$ \\
\hline KT07-02 & $\mathrm{TiO}_{2}$ & 4.2868 & 4.3290 & -0.0422 & $-1.0 \%$ \\
\hline KT07-02 & $\mathrm{ZnO}$ & 0.0345 & 0.0380 & -0.0035 & $-9.1 \%$ \\
\hline KT07-02 & $\mathrm{ZrO}_{2}$ & 0.9510 & 0.9990 & -0.0480 & $-4.8 \%$ \\
\hline KT07-02 & Sum & 99.1759 & 99.9230 & -0.7471 & $-0.7 \%$ \\
\hline KT07-03 & $\mathrm{Al}_{2} \mathrm{O}_{3}$ & 4.5348 & 4.4350 & 0.0998 & $2.3 \%$ \\
\hline KT07-03 & $\mathrm{B}_{2} \mathrm{O}_{3}$ & 5.9971 & 5.9990 & -0.0019 & $0.0 \%$ \\
\hline KT07-03 & $\mathrm{BaO}$ & 0.0645 & 0.0690 & -0.0045 & $-6.6 \%$ \\
\hline KT07-03 & $\mathrm{CaO}$ & 1.0228 & 0.9470 & 0.0758 & $8.0 \%$ \\
\hline KT07-03 & $\mathrm{Ce}_{2} \mathrm{O}_{3}$ & 0.2510 & 0.2520 & -0.0010 & $-0.4 \%$ \\
\hline KT07-03 & $\mathrm{Cr}_{2} \mathrm{O}_{3}$ & 0.1199 & 0.0900 & 0.0299 & $33.2 \%$ \\
\hline KT07-03 & $\mathrm{CuO}$ & 0.0476 & 0.0390 & 0.0086 & $22.0 \%$ \\
\hline KT07-03 & $\mathrm{Fe}_{2} \mathrm{O}_{3}$ & 11.2053 & 11.3910 & -0.1857 & $-1.6 \%$ \\
\hline KT07-03 & $\mathrm{K}_{2} \mathrm{O}$ & 0.0313 & 0.0370 & -0.0057 & $-15.4 \%$ \\
\hline KT07-03 & $\mathrm{La}_{2} \mathrm{O}_{3}$ & 0.0604 & 0.0720 & -0.0116 & $-16.1 \%$ \\
\hline KT07-03 & $\mathrm{Li}_{2} \mathrm{O}$ & 3.4500 & 3.5990 & -0.1490 & $-4.1 \%$ \\
\hline KT07-03 & $\mathrm{MgO}$ & 0.1538 & 0.1530 & 0.0008 & $0.5 \%$ \\
\hline KT07-03 & $\mathrm{MnO}$ & 1.8077 & 1.7880 & 0.0197 & $1.1 \%$ \\
\hline KT07-03 & $\mathrm{Na}_{2} \mathrm{O}$ & 13.8507 & 14.2300 & -0.3793 & $-2.7 \%$ \\
\hline KT07-03 & $\mathrm{Nb}_{2} \mathrm{O}_{5}$ & 1.0353 & 1.0870 & -0.0517 & $-4.8 \%$ \\
\hline KT07-03 & $\mathrm{NiO}$ & 0.3099 & 0.3130 & -0.0031 & $-1.0 \%$ \\
\hline KT07-03 & $\mathrm{PbO}$ & 0.1215 & 0.1330 & -0.0115 & $-8.7 \%$ \\
\hline KT07-03 & $\mathrm{SiO}_{2}$ & 48.2947 & 49.4970 & -1.2023 & $-2.4 \%$ \\
\hline KT07-03 & $\mathrm{SO}_{4}$ & 0.3767 & 0.4000 & -0.0233 & $-5.8 \%$ \\
\hline KT07-03 & $\mathrm{TiO}_{2}$ & 4.1992 & 4.3500 & -0.1508 & $-3.5 \%$ \\
\hline KT07-03 & $\mathrm{ZnO}$ & 0.0345 & 0.0380 & -0.0035 & $-9.1 \%$ \\
\hline KT07-03 & $\mathrm{ZrO}_{2}$ & 0.9722 & 1.0040 & -0.0318 & $-3.2 \%$ \\
\hline KT07-03 & Sum & 97.9408 & 99.9230 & -1.9822 & $-2.0 \%$ \\
\hline KT07-04 & $\mathrm{Al}_{2} \mathrm{O}_{3}$ & 5.1914 & 4.9140 & 0.2774 & $5.6 \%$ \\
\hline KT07-04 & $\mathrm{B}_{2} \mathrm{O}_{3}$ & 5.9810 & 5.9990 & -0.0180 & $-0.3 \%$ \\
\hline KT07-04 & $\mathrm{BaO}$ & 0.0620 & 0.0680 & -0.0060 & $-8.9 \%$ \\
\hline KT07-04 & $\mathrm{CaO}$ & 0.9137 & 0.8470 & 0.0667 & $7.9 \%$ \\
\hline KT07-04 & $\mathrm{Ce}_{2} \mathrm{O}_{3}$ & 0.2182 & 0.2130 & 0.0052 & $2.4 \%$ \\
\hline KT07-04 & $\mathrm{Cr}_{2} \mathrm{O}_{3}$ & 0.0935 & 0.0880 & 0.0055 & $6.3 \%$ \\
\hline KT07-04 & $\mathrm{CuO}$ & 0.0463 & 0.0380 & 0.0083 & $21.9 \%$ \\
\hline KT07-04 & $\mathrm{Fe}_{2} \mathrm{O}_{3}$ & 11.8415 & 12.0270 & -0.1855 & $-1.5 \%$ \\
\hline KT07-04 & $\mathrm{K}_{2} \mathrm{O}$ & 0.0304 & 0.0360 & -0.0056 & $-15.5 \%$ \\
\hline KT07-04 & $\mathrm{La}_{2} \mathrm{O}_{3}$ & 0.0578 & 0.0710 & -0.0132 & $-18.6 \%$ \\
\hline KT07-04 & $\mathrm{Li}_{2} \mathrm{O}$ & 3.4931 & 3.5990 & -0.1059 & $-2.9 \%$ \\
\hline KT07-04 & $\mathrm{MgO}$ & 0.1488 & 0.1510 & -0.0022 & $-1.4 \%$ \\
\hline KT07-04 & $\mathrm{MnO}$ & 1.0736 & 1.0550 & 0.0186 & $1.8 \%$ \\
\hline KT07-04 & $\mathrm{Na}_{2} \mathrm{O}$ & 13.7867 & 13.6710 & 0.1157 & $0.8 \%$ \\
\hline KT07-04 & $\mathrm{Nb}_{2} \mathrm{O}_{5}$ & 0.9327 & 1.0430 & -0.1103 & $-10.6 \%$ \\
\hline KT07-04 & $\mathrm{NiO}$ & 0.1476 & 0.1540 & -0.0064 & $-4.1 \%$ \\
\hline KT07-04 & $\mathrm{PbO}$ & 0.0902 & 0.0980 & -0.0078 & $-7.9 \%$ \\
\hline KT07-04 & $\mathrm{SiO}_{2}$ & 48.4017 & 50.0880 & -1.6863 & $-3.4 \%$ \\
\hline KT07-04 & $\mathrm{SO}_{4}$ & 0.3827 & 0.4000 & -0.0173 & $-4.3 \%$ \\
\hline KT07-04 & $\mathrm{TiO}_{2}$ & 4.3577 & 4.3610 & -0.0034 & $-0.1 \%$ \\
\hline KT07-04 & $\mathrm{ZnO}$ & 0.0710 & 0.0750 & -0.0040 & $-5.4 \%$ \\
\hline KT07-04 & $\mathrm{ZrO}_{2}$ & 0.8672 & 0.9270 & -0.0598 & $-6.4 \%$ \\
\hline KT07-04 & Sum & 98.1886 & 99.9230 & -1.7344 & $-1.7 \%$ \\
\hline KT07-05 & $\mathrm{Al}_{2} \mathrm{O}_{3}$ & 7.0242 & 6.8050 & 0.2192 & $3.2 \%$ \\
\hline KT07-05 & $\mathrm{B}_{2} \mathrm{O}_{3}$ & 6.1420 & 5.9990 & 0.1430 & $2.4 \%$ \\
\hline
\end{tabular}


Table A-4. Comparison of Measured versus Targeted Composition for the KT07-Series Glasses. (continued)

\begin{tabular}{|c|c|c|c|c|c|}
\hline Glass ID & Oxide & Measured (wt \%) & Targeted (wt \%) & $\begin{array}{c}\text { Difference (wt\%) of } \\
\text { Measured vs Targeted }\end{array}$ & $\begin{array}{c}\text { \% Difference of } \\
\text { Measured vs Targeted }\end{array}$ \\
\hline KT07-05 & $\mathrm{BaO}$ & 0.0625 & 0.0680 & -0.0055 & $-8.1 \%$ \\
\hline KT07-05 & $\mathrm{CaO}$ & 1.0977 & 0.9310 & 0.1667 & $17.9 \%$ \\
\hline KT07-05 & $\mathrm{Ce}_{2} \mathrm{O}_{3}$ & 0.1476 & 0.1420 & 0.0056 & $3.9 \%$ \\
\hline KT07-05 & $\mathrm{Cr}_{2} \mathrm{O}_{3}$ & 0.1389 & 0.1330 & 0.0059 & $4.4 \%$ \\
\hline KT07-05 & $\mathrm{CuO}$ & 0.0504 & 0.0380 & 0.0124 & $32.6 \%$ \\
\hline KT07-05 & $\mathrm{Fe}_{2} \mathrm{O}_{3}$ & 9.5575 & 9.5540 & 0.0035 & $0.0 \%$ \\
\hline KT07-05 & $\mathrm{K}_{2} \mathrm{O}$ & 0.0711 & 0.0730 & -0.0019 & $-2.6 \%$ \\
\hline KT07-05 & $\mathrm{La}_{2} \mathrm{O}_{3}$ & 0.0598 & 0.0710 & -0.0112 & $-15.8 \%$ \\
\hline KT07-05 & $\mathrm{Li}_{2} \mathrm{O}$ & 3.4716 & 3.5990 & -0.1274 & $-3.5 \%$ \\
\hline KT07-05 & $\mathrm{MgO}$ & 0.1555 & 0.1500 & 0.0055 & $3.6 \%$ \\
\hline KT07-05 & $\mathrm{MnO}$ & 1.0317 & 1.0150 & 0.0167 & $1.6 \%$ \\
\hline KT07-05 & $\mathrm{Na}_{2} \mathrm{O}$ & 13.6215 & 13.6310 & -0.0095 & $-0.1 \%$ \\
\hline KT07-05 & $\mathrm{Nb}_{2} \mathrm{O}_{5}$ & 1.0403 & 1.0680 & -0.0277 & $-2.6 \%$ \\
\hline KT07-05 & $\mathrm{NiO}$ & 0.1126 & 0.1150 & -0.0024 & $-2.1 \%$ \\
\hline KT07-05 & $\mathrm{PbO}$ & 0.0587 & 0.0650 & -0.0063 & $-9.7 \%$ \\
\hline KT07-05 & $\mathrm{SiO}_{2}$ & 49.9527 & 50.6250 & -0.6723 & $-1.3 \%$ \\
\hline KT07-05 & $\mathrm{SO}_{4}$ & 0.3730 & 0.4000 & -0.0270 & $-6.8 \%$ \\
\hline KT07-05 & $\mathrm{TiO}_{2}$ & 4.3201 & 4.4160 & -0.0959 & $-2.2 \%$ \\
\hline KT07-05 & $\mathrm{ZnO}$ & 0.0579 & 0.0380 & 0.0199 & $52.3 \%$ \\
\hline KT07-05 & $\mathrm{ZrO}_{2}$ & 0.9945 & 0.9860 & 0.0085 & $0.9 \%$ \\
\hline KT07-05 & Sum & 99.5417 & 99.9220 & -0.3803 & $-0.4 \%$ \\
\hline KT07-06 & $\mathrm{Al}_{2} \mathrm{O}_{3}$ & 7.3879 & 7.2280 & 0.1599 & $2.2 \%$ \\
\hline KT07-06 & $\mathrm{B}_{2} \mathrm{O}_{3}$ & 5.7395 & 5.9990 & -0.2595 & $-4.3 \%$ \\
\hline KT07-06 & $\mathrm{BaO}$ & 0.0614 & 0.0680 & -0.0066 & $-9.7 \%$ \\
\hline KT07-06 & $\mathrm{CaO}$ & 1.0029 & 0.9850 & 0.0179 & $1.8 \%$ \\
\hline KT07-06 & $\mathrm{Ce}_{2} \mathrm{O}_{3}$ & 0.1101 & 0.1080 & 0.0021 & $1.9 \%$ \\
\hline KT07-06 & $\mathrm{Cr}_{2} \mathrm{O}_{3}$ & 0.1385 & 0.1340 & 0.0045 & $3.3 \%$ \\
\hline KT07-06 & $\mathrm{CuO}$ & 0.0466 & 0.0380 & 0.0086 & $22.7 \%$ \\
\hline KT07-06 & $\mathrm{Fe}_{2} \mathrm{O}_{3}$ & 9.0965 & 9.0170 & 0.0795 & $0.9 \%$ \\
\hline KT07-06 & $\mathrm{K}_{2} \mathrm{O}$ & 0.1181 & 0.1110 & 0.0071 & $6.4 \%$ \\
\hline KT07-06 & $\mathrm{La}_{2} \mathrm{O}_{3}$ & 0.0264 & 0.0360 & -0.0096 & $-26.7 \%$ \\
\hline KT07-06 & $\mathrm{Li}_{2} \mathrm{O}$ & 3.2939 & 3.5990 & -0.3051 & $-8.5 \%$ \\
\hline KT07-06 & $\mathrm{MgO}$ & 0.0970 & 0.1020 & -0.0050 & $-4.9 \%$ \\
\hline KT07-06 & $\mathrm{MnO}$ & 1.1908 & 1.1860 & 0.0048 & $0.4 \%$ \\
\hline KT07-06 & $\mathrm{Na}_{2} \mathrm{O}$ & 13.4834 & 13.6450 & -0.1616 & $-1.2 \%$ \\
\hline KT07-06 & $\mathrm{Nb}_{2} \mathrm{O}_{5}$ & 0.9466 & 1.0230 & -0.0764 & $-7.5 \%$ \\
\hline KT07-06 & $\mathrm{NiO}$ & 0.1489 & 0.1560 & -0.0071 & $-4.6 \%$ \\
\hline KT07-06 & $\mathrm{PbO}$ & 0.0611 & 0.0660 & -0.0049 & $-7.4 \%$ \\
\hline KT07-06 & $\mathrm{SiO}_{2}$ & 48.9365 & 50.6160 & -1.6795 & $-3.3 \%$ \\
\hline KT07-06 & $\mathrm{SO}_{4}$ & 0.3707 & 0.4000 & -0.0293 & $-7.3 \%$ \\
\hline KT07-06 & $\mathrm{TiO}_{2}$ & 4.2701 & 4.3730 & -0.1029 & $-2.4 \%$ \\
\hline KT07-06 & $\mathrm{ZnO}$ & 0.0710 & 0.0760 & -0.0050 & $-6.6 \%$ \\
\hline KT07-06 & $\mathrm{ZrO}_{2}$ & 0.9118 & 0.9560 & -0.0442 & $-4.6 \%$ \\
\hline KT07-06 & Sum & 97.5097 & 99.9220 & -2.4123 & $-2.4 \%$ \\
\hline KT07-07 & $\mathrm{Al}_{2} \mathrm{O}_{3}$ & 5.6685 & 5.6200 & 0.0485 & $0.9 \%$ \\
\hline KT07-07 & $\mathrm{B}_{2} \mathrm{O}_{3}$ & 5.8683 & 5.9990 & -0.1307 & $-2.2 \%$ \\
\hline KT07-07 & $\mathrm{BaO}$ & 0.0689 & 0.0750 & -0.0061 & $-8.1 \%$ \\
\hline KT07-07 & $\mathrm{CaO}$ & 0.9315 & 0.8900 & 0.0415 & $4.7 \%$ \\
\hline KT07-07 & $\mathrm{Ce}_{2} \mathrm{O}_{3}$ & 0.0776 & 0.0780 & -0.0004 & $-0.5 \%$ \\
\hline KT07-07 & $\mathrm{Cr}_{2} \mathrm{O}_{3}$ & 0.1549 & 0.1470 & 0.0079 & $5.4 \%$ \\
\hline KT07-07 & $\mathrm{CuO}$ & 0.0529 & 0.0420 & 0.0109 & $25.9 \%$ \\
\hline KT07-07 & $\mathrm{Fe}_{2} \mathrm{O}_{3}$ & 9.3181 & 9.3780 & -0.0599 & $-0.6 \%$ \\
\hline KT07-07 & $\mathrm{K}_{2} \mathrm{O}$ & 0.0774 & 0.0810 & -0.0036 & $-4.4 \%$ \\
\hline KT07-07 & $\mathrm{La}_{2} \mathrm{O}_{3}$ & 0.0267 & 0.0390 & -0.0123 & $-31.6 \%$ \\
\hline KT07-07 & $\mathrm{Li}_{2} \mathrm{O}$ & 3.4016 & 3.5990 & -0.1974 & $-5.5 \%$ \\
\hline KT07-07 & $\mathrm{MgO}$ & 0.1090 & 0.1110 & -0.0020 & $-1.8 \%$ \\
\hline KT07-07 & $\mathrm{MnO}$ & 0.7244 & 0.7350 & -0.0106 & $-1.4 \%$ \\
\hline KT07-07 & $\mathrm{Na}_{2} \mathrm{O}$ & 14.0192 & 14.5080 & -0.4888 & $-3.4 \%$ \\
\hline
\end{tabular}


Table A-4. Comparison of Measured versus Targeted Composition for the KT07-Series Glasses. (continued)

\begin{tabular}{|c|c|c|c|c|c|}
\hline Glass ID & Oxide & Measured (wt \%) & Targeted (wt \%) & $\begin{array}{c}\text { Difference (wt\%) of } \\
\text { Measured vs Targeted }\end{array}$ & $\begin{array}{c}\text { \% Difference of } \\
\text { Measured vs Targeted }\end{array}$ \\
\hline KT07-07 & $\mathrm{Nb}_{2} \mathrm{O}_{5}$ & 1.1290 & 1.1930 & -0.0640 & $-5.4 \%$ \\
\hline KT07-07 & $\mathrm{NiO}$ & 0.6191 & 0.6390 & -0.0199 & $-3.1 \%$ \\
\hline KT07-07 & $\mathrm{PbO}$ & 0.0700 & 0.0720 & -0.0020 & $-2.8 \%$ \\
\hline KT07-07 & $\mathrm{SiO}_{2}$ & 48.9365 & 50.3350 & -1.3985 & $-2.8 \%$ \\
\hline KT07-07 & $\mathrm{SO}_{4}$ & 0.3887 & 0.4000 & -0.0113 & $-2.8 \%$ \\
\hline KT07-07 & $\mathrm{TiO}_{2}$ & 4.7747 & 4.8460 & -0.0713 & $-1.5 \%$ \\
\hline KT07-07 & $\mathrm{ZnO}$ & 0.0825 & 0.0830 & -0.0005 & $-0.6 \%$ \\
\hline KT07-07 & $\mathrm{ZrO}_{2}$ & 1.0276 & 1.0540 & -0.0264 & $-2.5 \%$ \\
\hline KT07-07 & Sum & 97.5270 & 99.9240 & -2.3970 & $-2.4 \%$ \\
\hline KT07-08 & $\mathrm{Al}_{2} \mathrm{O}_{3}$ & 5.0922 & 5.0110 & 0.0812 & $1.6 \%$ \\
\hline KT07-08 & $\mathrm{B}_{2} \mathrm{O}_{3}$ & 6.0695 & 5.9990 & 0.0705 & $1.2 \%$ \\
\hline KT07-08 & $\mathrm{BaO}$ & 0.0715 & 0.0750 & -0.0035 & $-4.7 \%$ \\
\hline KT07-08 & $\mathrm{CaO}$ & 0.8979 & 0.8040 & 0.0939 & $11.7 \%$ \\
\hline KT07-08 & $\mathrm{Ce}_{2} \mathrm{O}_{3}$ & 0.0794 & 0.0790 & 0.0004 & $0.5 \%$ \\
\hline KT07-08 & $\mathrm{Cr}_{2} \mathrm{O}_{3}$ & 0.1085 & 0.0990 & 0.0095 & $9.6 \%$ \\
\hline KT07-08 & $\mathrm{CuO}$ & 0.0429 & 0.0420 & 0.0009 & $2.1 \%$ \\
\hline KT07-08 & $\mathrm{Fe}_{2} \mathrm{O}_{3}$ & 9.1251 & 9.1310 & -0.0059 & $-0.1 \%$ \\
\hline KT07-08 & $\mathrm{K}_{2} \mathrm{O}$ & 0.0735 & 0.0810 & -0.0075 & $-9.3 \%$ \\
\hline KT07-08 & $\mathrm{La}_{2} \mathrm{O}_{3}$ & 0.0293 & 0.0400 & -0.0107 & $-26.7 \%$ \\
\hline KT07-08 & $\mathrm{Li}_{2} \mathrm{O}$ & 3.4393 & 3.5990 & -0.1597 & $-4.4 \%$ \\
\hline KT07-08 & $\mathrm{MgO}$ & 0.1136 & 0.1120 & 0.0016 & $1.4 \%$ \\
\hline KT07-08 & $\mathrm{MnO}$ & 0.9626 & 0.9600 & 0.0026 & $0.3 \%$ \\
\hline KT07-08 & $\mathrm{Na}_{2} \mathrm{O}$ & 14.9291 & 15.4110 & -0.4819 & $-3.1 \%$ \\
\hline KT07-08 & $\mathrm{Nb}_{2} \mathrm{O}_{5}$ & 1.2756 & 1.2940 & -0.0184 & $-1.4 \%$ \\
\hline KT07-08 & $\mathrm{NiO}$ & 0.5904 & 0.6020 & -0.0116 & $-1.9 \%$ \\
\hline KT07-08 & $\mathrm{PbO}$ & 0.0676 & 0.0730 & -0.0054 & $-7.4 \%$ \\
\hline KT07-08 & $\mathrm{SiO}_{2}$ & 48.5086 & 50.0060 & -1.4974 & $-3.0 \%$ \\
\hline KT07-08 & $\mathrm{SO}_{4}$ & 0.3827 & 0.4000 & -0.0173 & $-4.3 \%$ \\
\hline KT07-08 & $\mathrm{TiO}_{2}$ & 4.8872 & 4.9320 & -0.0448 & $-0.9 \%$ \\
\hline KT07-08 & $\mathrm{ZnO}$ & 0.0417 & 0.0420 & -0.0003 & $-0.7 \%$ \\
\hline KT07-08 & $\mathrm{ZrO}_{2}$ & 1.1060 & 1.1300 & -0.0240 & $-2.1 \%$ \\
\hline KT07-08 & Sum & 97.8942 & 99.9220 & -2.0278 & $-2.0 \%$ \\
\hline KT07-09 & $\mathrm{Al}_{2} \mathrm{O}_{3}$ & 5.5126 & 5.4600 & 0.0526 & $1.0 \%$ \\
\hline KT07-09 & $\mathrm{B}_{2} \mathrm{O}_{3}$ & 5.9810 & 5.9990 & -0.0180 & $-0.3 \%$ \\
\hline KT07-09 & $\mathrm{BaO}$ & 0.0689 & 0.0760 & -0.0071 & $-9.3 \%$ \\
\hline KT07-09 & $\mathrm{CaO}$ & 1.0022 & 0.9510 & 0.0512 & $5.4 \%$ \\
\hline KT07-09 & $\mathrm{Ce}_{2} \mathrm{O}_{3}$ & 0.1944 & 0.1990 & -0.0046 & $-2.3 \%$ \\
\hline KT07-09 & $\mathrm{Cr}_{2} \mathrm{O}_{3}$ & 0.1063 & 0.0990 & 0.0073 & $7.4 \%$ \\
\hline KT07-09 & $\mathrm{CuO}$ & 0.0404 & 0.0430 & -0.0026 & $-6.1 \%$ \\
\hline KT07-09 & $\mathrm{Fe}_{2} \mathrm{O}_{3}$ & 12.0524 & 12.2890 & -0.2366 & $-1.9 \%$ \\
\hline KT07-09 & $\mathrm{K}_{2} \mathrm{O}$ & 0.0831 & 0.0820 & 0.0011 & $1.4 \%$ \\
\hline KT07-09 & $\mathrm{La}_{2} \mathrm{O}_{3}$ & 0.0625 & 0.0800 & -0.0175 & $-21.9 \%$ \\
\hline KT07-09 & $\mathrm{Li}_{2} \mathrm{O}$ & 3.4123 & 3.5990 & -0.1867 & $-5.2 \%$ \\
\hline KT07-09 & $\mathrm{MgO}$ & 0.1078 & 0.1130 & -0.0052 & $-4.6 \%$ \\
\hline KT07-09 & $\mathrm{MnO}$ & 0.5559 & 0.5700 & -0.0141 & $-2.5 \%$ \\
\hline KT07-09 & $\mathrm{Na}_{2} \mathrm{O}$ & 13.6687 & 14.0230 & -0.3543 & $-2.5 \%$ \\
\hline KT07-09 & $\mathrm{Nb}_{2} \mathrm{O}_{5}$ & 0.7156 & 0.8450 & -0.1294 & $-15.3 \%$ \\
\hline KT07-09 & $\mathrm{NiO}$ & 0.4867 & 0.5190 & -0.0323 & $-6.2 \%$ \\
\hline KT07-09 & $\mathrm{PbO}$ & 0.1236 & 0.1460 & -0.0224 & $-15.3 \%$ \\
\hline KT07-09 & $\mathrm{SiO}_{2}$ & 46.9042 & 48.7610 & -1.8568 & $-3.8 \%$ \\
\hline KT07-09 & $\mathrm{SO}_{4}$ & 0.3633 & 0.4000 & -0.0367 & $-9.2 \%$ \\
\hline KT07-09 & $\mathrm{TiO}_{2}$ & 4.7455 & 4.8240 & -0.0785 & $-1.6 \%$ \\
\hline KT07-09 & $\mathrm{ZnO}$ & 0.0386 & 0.0420 & -0.0034 & $-8.1 \%$ \\
\hline KT07-09 & $\mathrm{ZrO}_{2}$ & 0.7416 & 0.8020 & -0.0604 & $-7.5 \%$ \\
\hline KT07-09 & Sum & 96.9675 & 99.9220 & -2.9545 & $-3.0 \%$ \\
\hline KT07-10 & $\mathrm{Al}_{2} \mathrm{O}_{3}$ & 5.7583 & 5.6090 & 0.1493 & $2.7 \%$ \\
\hline KT07-10 & $\mathrm{B}_{2} \mathrm{O}_{3}$ & 6.1178 & 5.9990 & 0.1188 & $2.0 \%$ \\
\hline KT07-10 & $\mathrm{BaO}$ & 0.0715 & 0.0770 & -0.0055 & $-7.2 \%$ \\
\hline
\end{tabular}


Table A-4. Comparison of Measured versus Targeted Composition for the KT07-Series Glasses. (continued)

\begin{tabular}{|c|c|c|c|c|c|}
\hline Glass ID & Oxide & Measured (wt \%) & Targeted (wt \%) & $\begin{array}{c}\text { Difference (wt\%) of } \\
\text { Measured vs Targeted }\end{array}$ & $\begin{array}{c}\text { \% Difference of } \\
\text { Measured vs Targeted }\end{array}$ \\
\hline KT07-10 & $\mathrm{CaO}$ & 1.0491 & 0.9700 & 0.0791 & $8.1 \%$ \\
\hline KT07-10 & $\mathrm{Ce}_{2} \mathrm{O}_{3}$ & 0.2401 & 0.2440 & -0.0039 & $-1.6 \%$ \\
\hline KT07-10 & $\mathrm{Cr}_{2} \mathrm{O}_{3}$ & 0.1104 & 0.1010 & 0.0094 & $9.3 \%$ \\
\hline KT07-10 & $\mathrm{CuO}$ & 0.0469 & 0.0430 & 0.0039 & $9.2 \%$ \\
\hline KT07-10 & $\mathrm{Fe}_{2} \mathrm{O}_{3}$ & 13.3534 & 13.5760 & -0.2226 & $-1.6 \%$ \\
\hline KT07-10 & $\mathrm{K}_{2} \mathrm{O}$ & 0.0407 & 0.0420 & -0.0013 & $-3.2 \%$ \\
\hline KT07-10 & $\mathrm{La}_{2} \mathrm{O}_{3}$ & 0.0657 & 0.0810 & -0.0153 & $-18.9 \%$ \\
\hline KT07-10 & $\mathrm{Li}_{2} \mathrm{O}$ & 3.4823 & 3.5990 & -0.1167 & $-3.2 \%$ \\
\hline KT07-10 & $\mathrm{MgO}$ & 0.1099 & 0.1150 & -0.0051 & $-4.5 \%$ \\
\hline KT07-10 & $\mathrm{MnO}$ & 0.3932 & 0.4030 & -0.0098 & $-2.4 \%$ \\
\hline KT07-10 & $\mathrm{Na}_{2} \mathrm{O}$ & 13.5272 & 13.5050 & 0.0222 & $0.2 \%$ \\
\hline KT07-10 & $\mathrm{Nb}_{2} \mathrm{O}_{5}$ & 0.7303 & 0.7850 & -0.0547 & $-7.0 \%$ \\
\hline KT07-10 & $\mathrm{NiO}$ & 0.4559 & 0.4850 & -0.0291 & $-6.0 \%$ \\
\hline KT07-10 & $\mathrm{PbO}$ & 0.1344 & 0.1490 & -0.0146 & $-9.8 \%$ \\
\hline KT07-10 & $\mathrm{SiO}_{2}$ & 47.0646 & 48.4280 & -1.3634 & $-2.8 \%$ \\
\hline KT07-10 & $\mathrm{SO}_{4}$ & 0.3580 & 0.4000 & -0.0420 & $-10.5 \%$ \\
\hline KT07-10 & $\mathrm{TiO}_{2}$ & 4.4536 & 4.5050 & -0.0514 & $-1.1 \%$ \\
\hline KT07-10 & $\mathrm{ZnO}$ & 0.0392 & 0.0430 & -0.0038 & $-8.8 \%$ \\
\hline KT07-10 & $\mathrm{ZrO}_{2}$ & 0.7423 & 0.7620 & -0.0197 & $-2.6 \%$ \\
\hline KT07-10 & Sum & 98.3444 & 99.9210 & -1.5766 & $-1.6 \%$ \\
\hline
\end{tabular}


Exhibit A-1. Measurements in Analytical Sequence for the KT07-Series by Preparation Method by Oxide.

Prep Method=LM, Oxide=Al2O3 (wt\%)

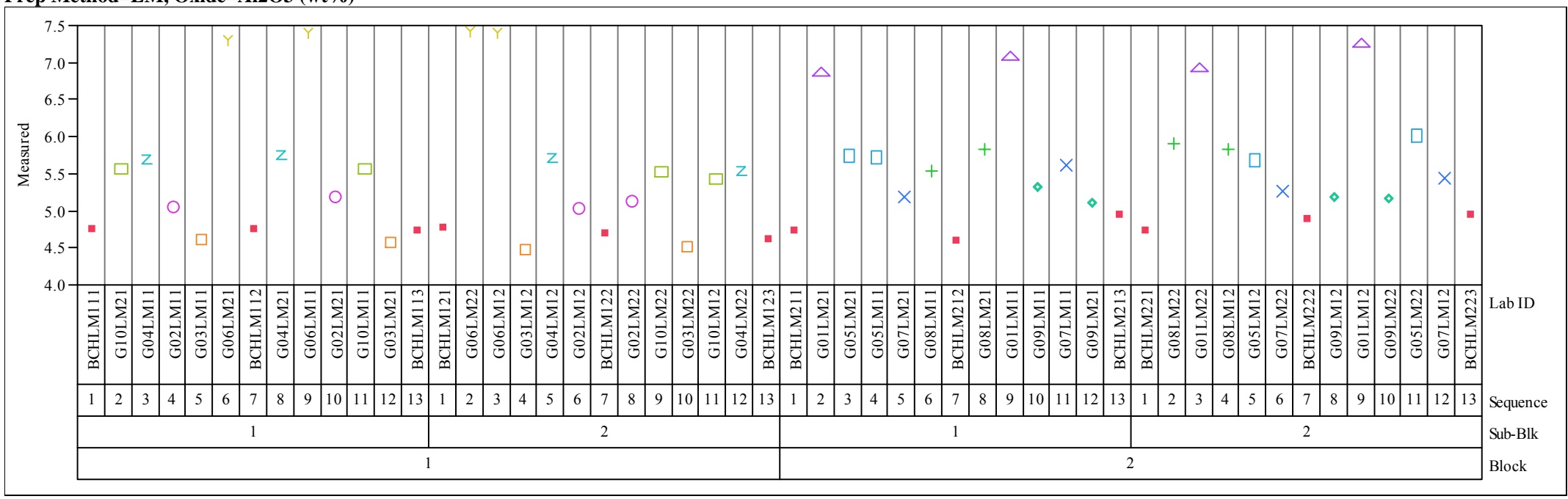

Prep Method=LM, Oxide=BaO (wt \%)

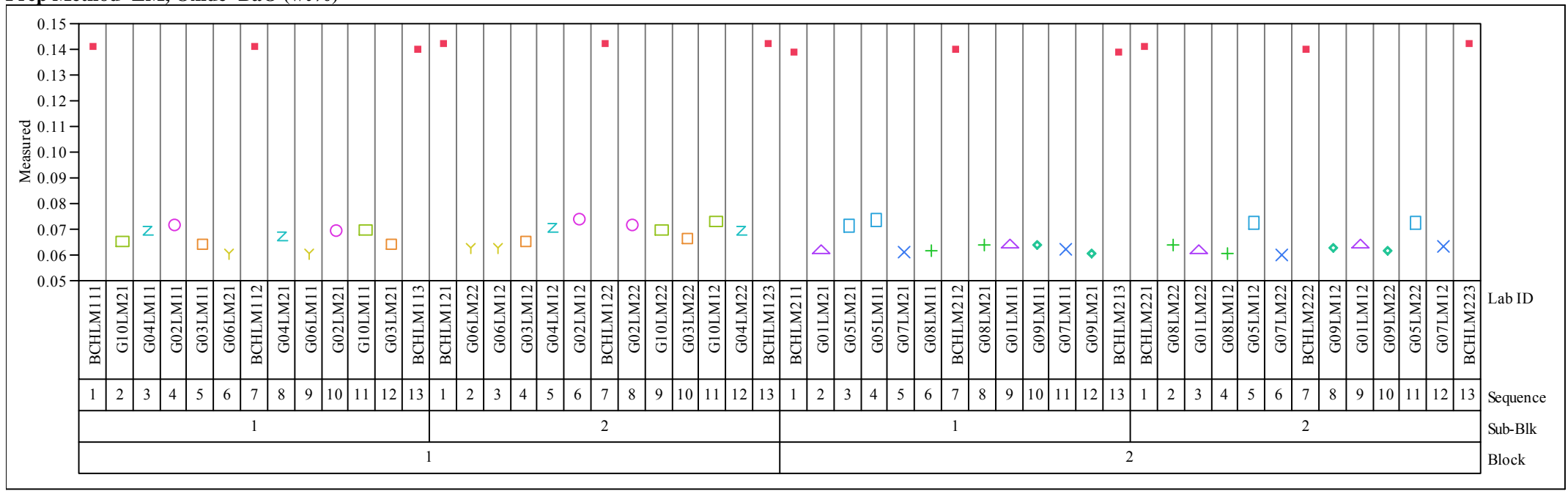


Exhibit A-1. Measurements in Analytical Sequence for the KT07-Series by Preparation Method by Oxide. (continued) Prep Method $=$ LM, Oxide $=\mathrm{CaO}(\mathrm{wt} \%)$

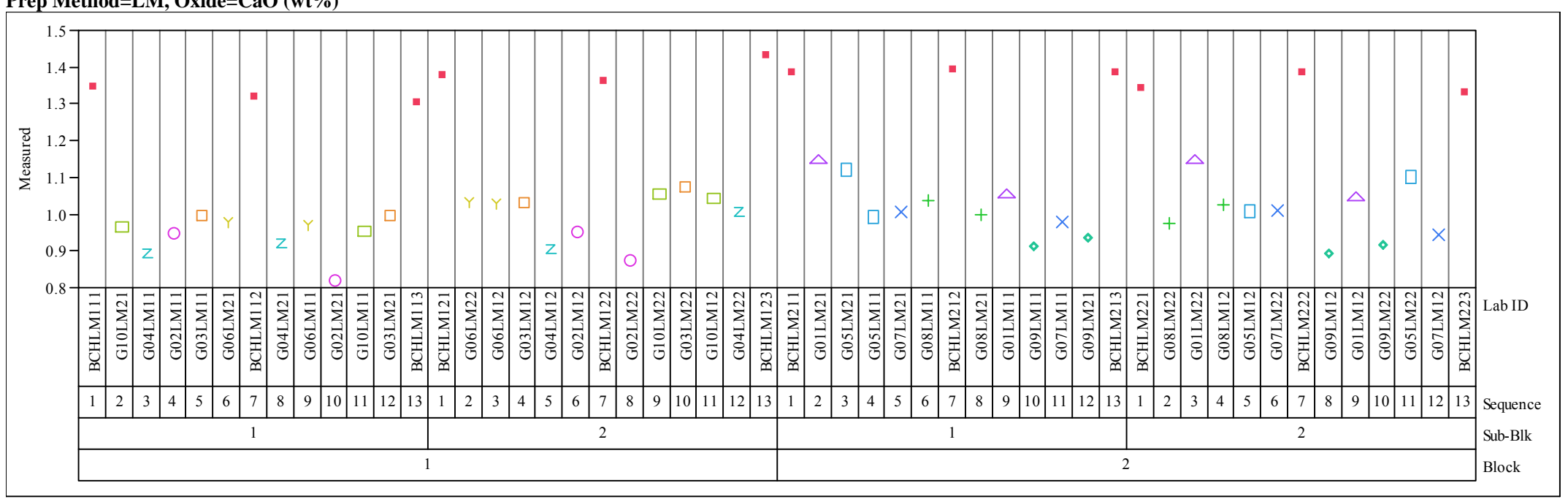

Prep Method=LM, Oxide=Ce2O3 (wt \%)

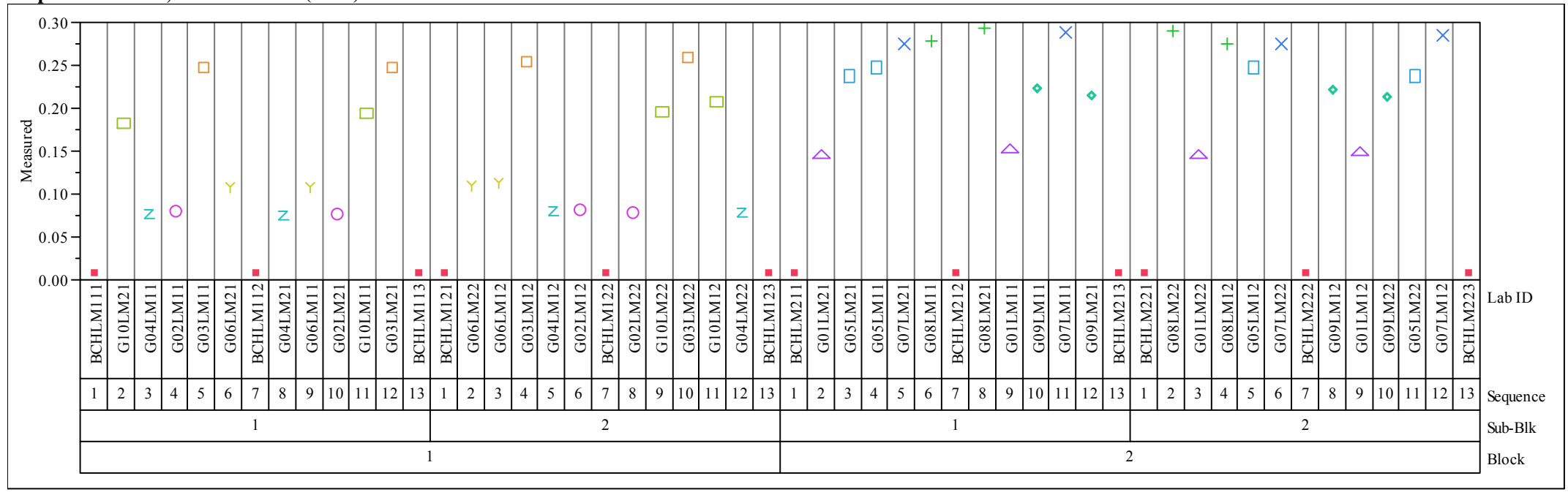


Exhibit A-1. Measurements in Analytical Sequence for the KT07-Series by Preparation Method by Oxide. (continued) Prep Method=LM, Oxide=Cr2O3 (wt\%)

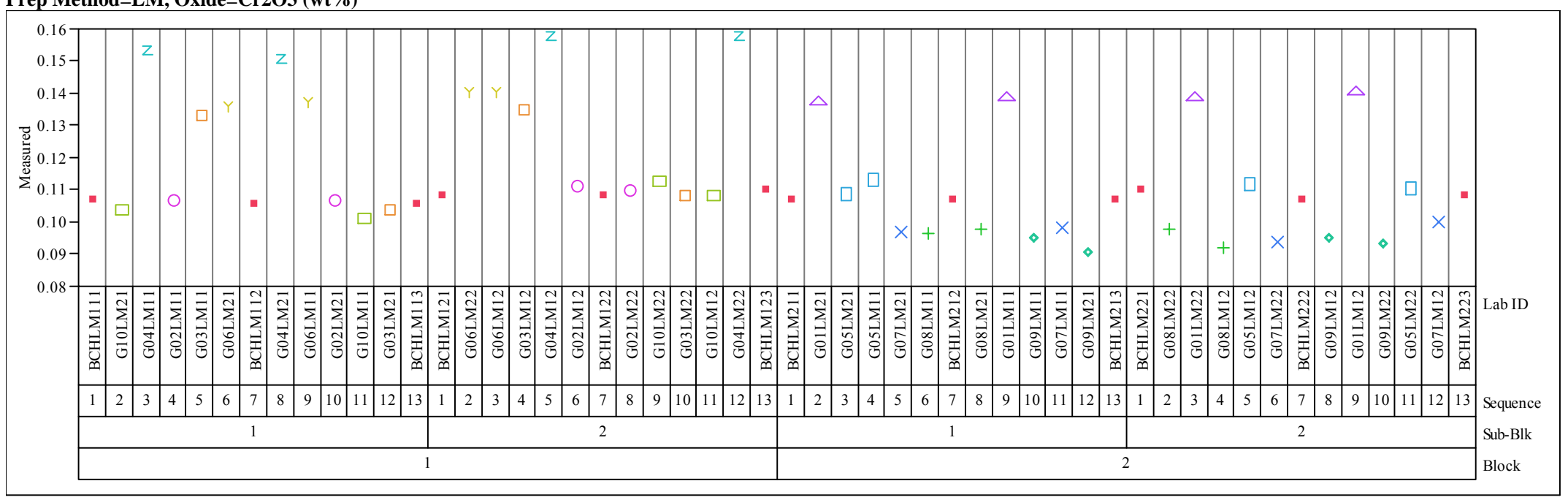

Prep Method=LM, Oxide $=\mathrm{CuO}($ wt $\%)$

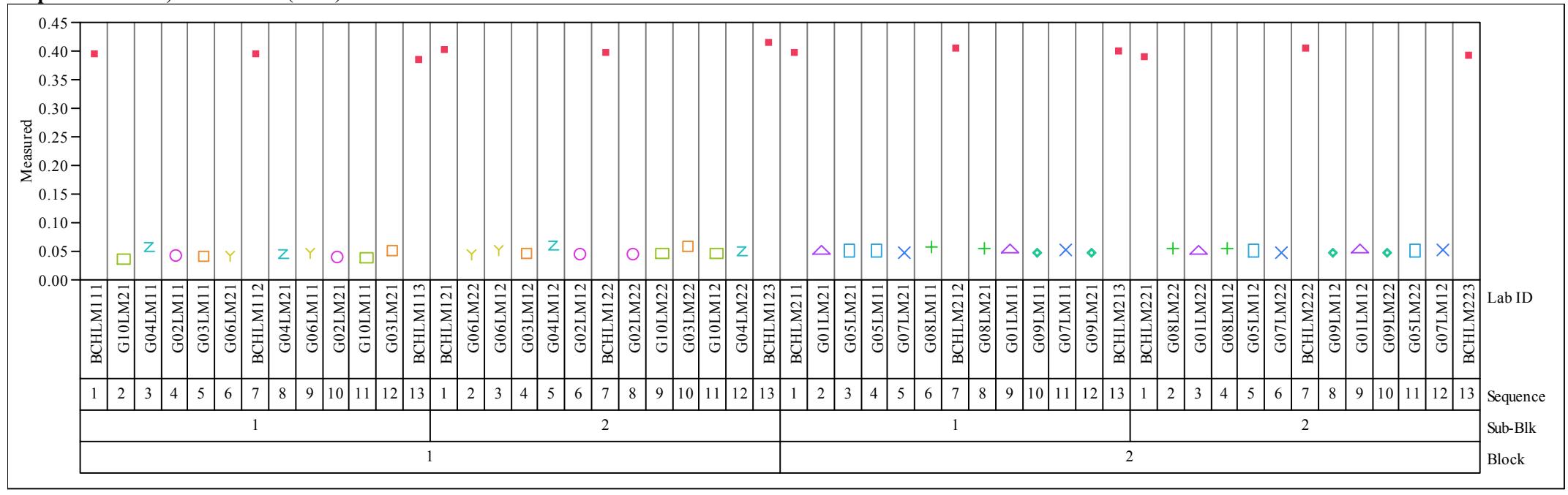


Exhibit A-1. Measurements in Analytical Sequence for the KT07-Series by Preparation Method by Oxide. (continued) Prep Method=LM, Oxide=Fe2O3 (wt\%)

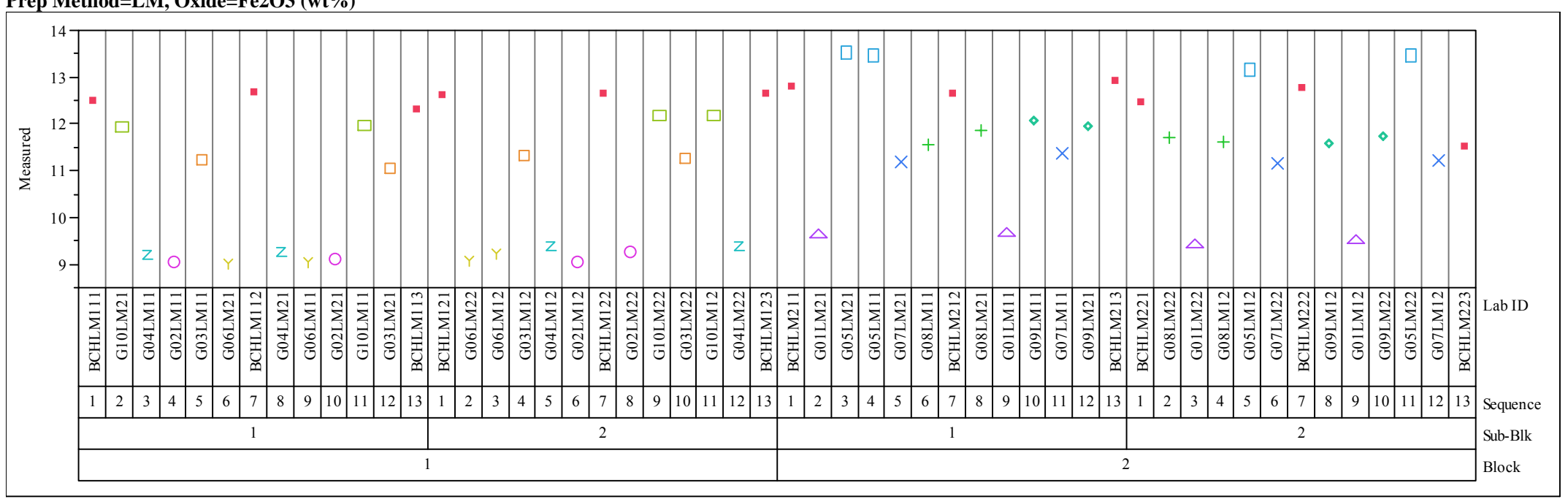

Prep Method=LM, Oxide=K2O (wt \%)

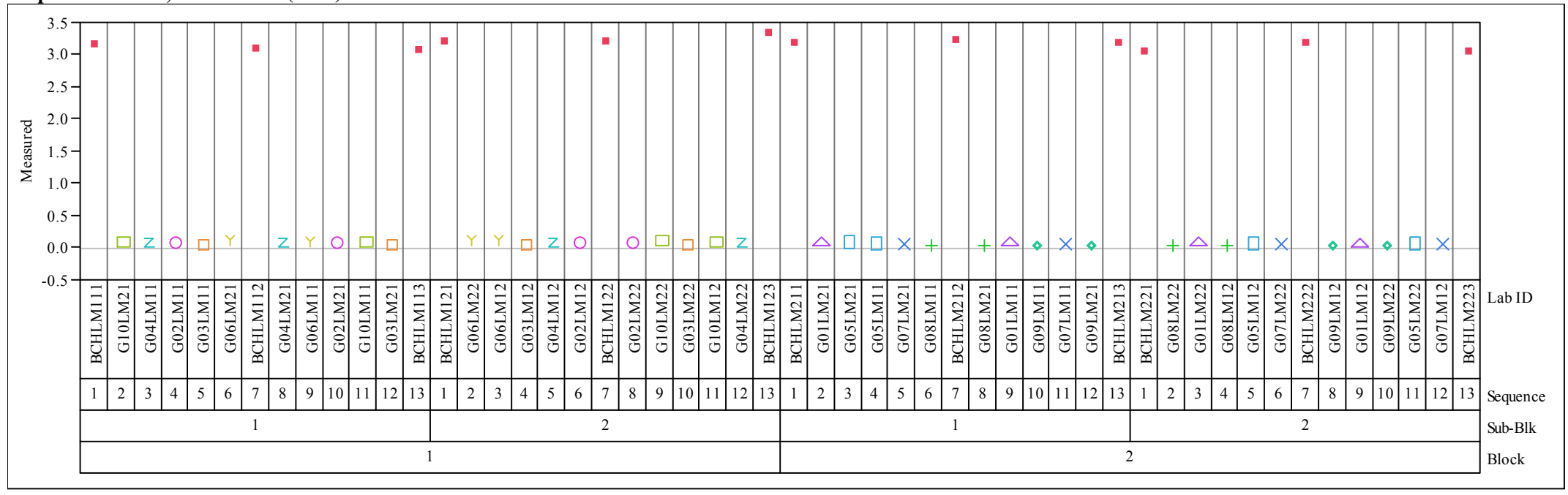


Exhibit A-1. Measurements in Analytical Sequence for the KT07-Series by Preparation Method by Oxide. (continued) Prep Method=LM, Oxide=La2O3 (wt \%)

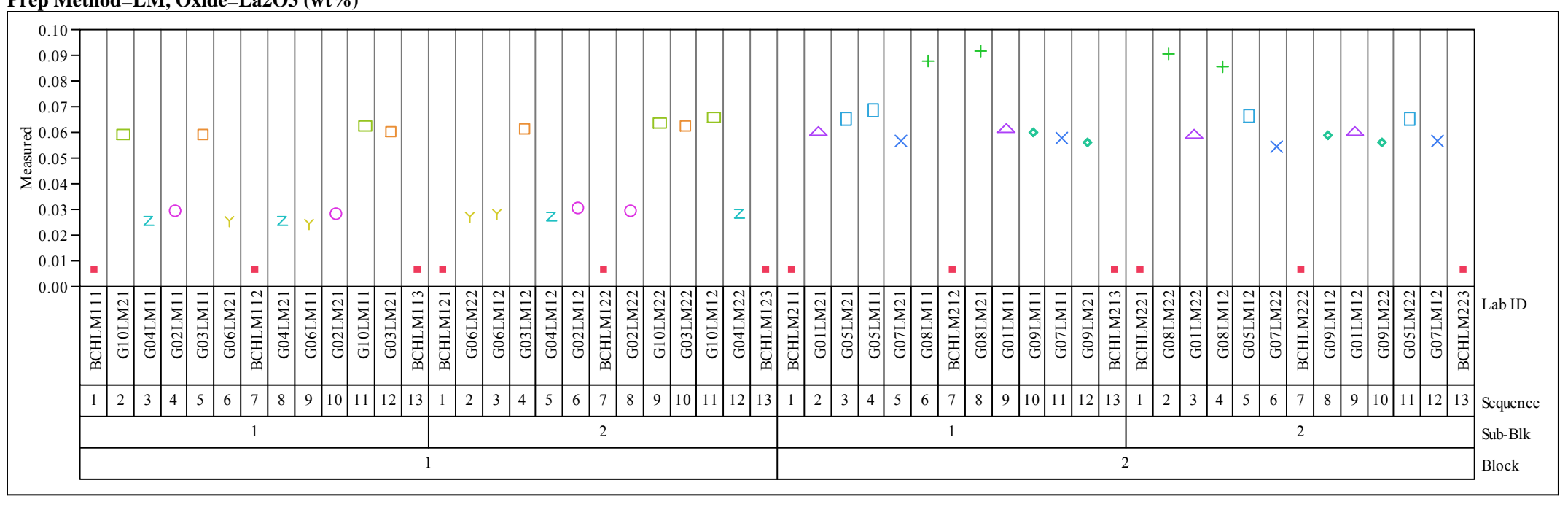

Prep Method=LM, Oxide=MgO (wt \%)

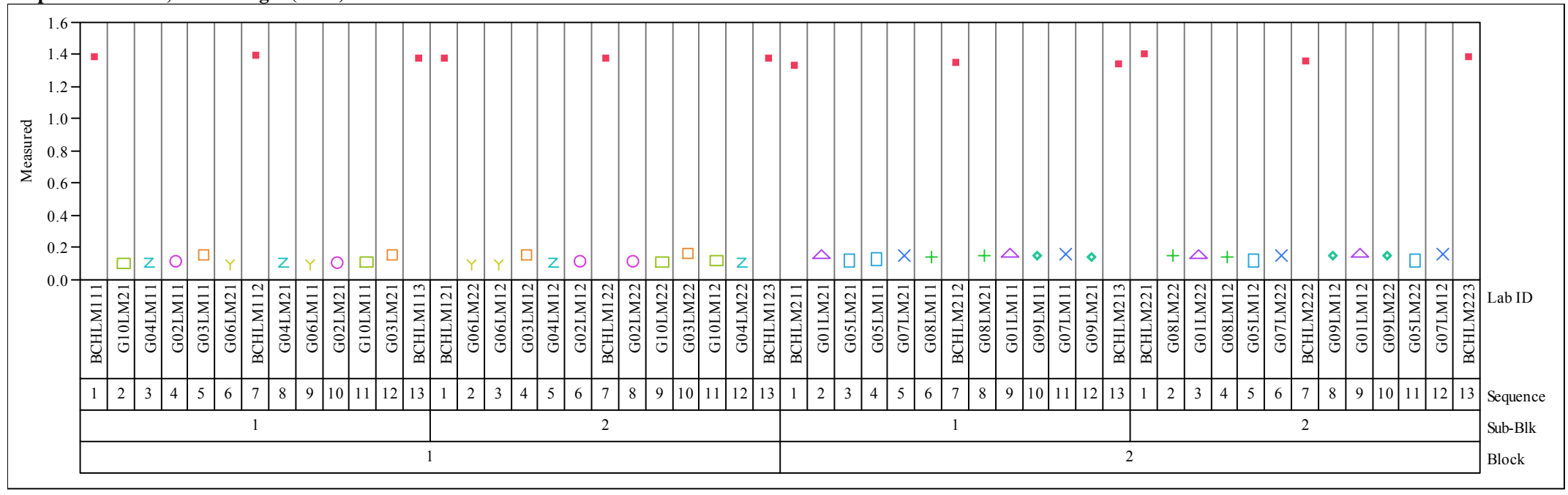


Exhibit A-1. Measurements in Analytical Sequence for the KT07-Series by Preparation Method by Oxide. (continued) Prep Method=LM, Oxide=MnO (wt\%)

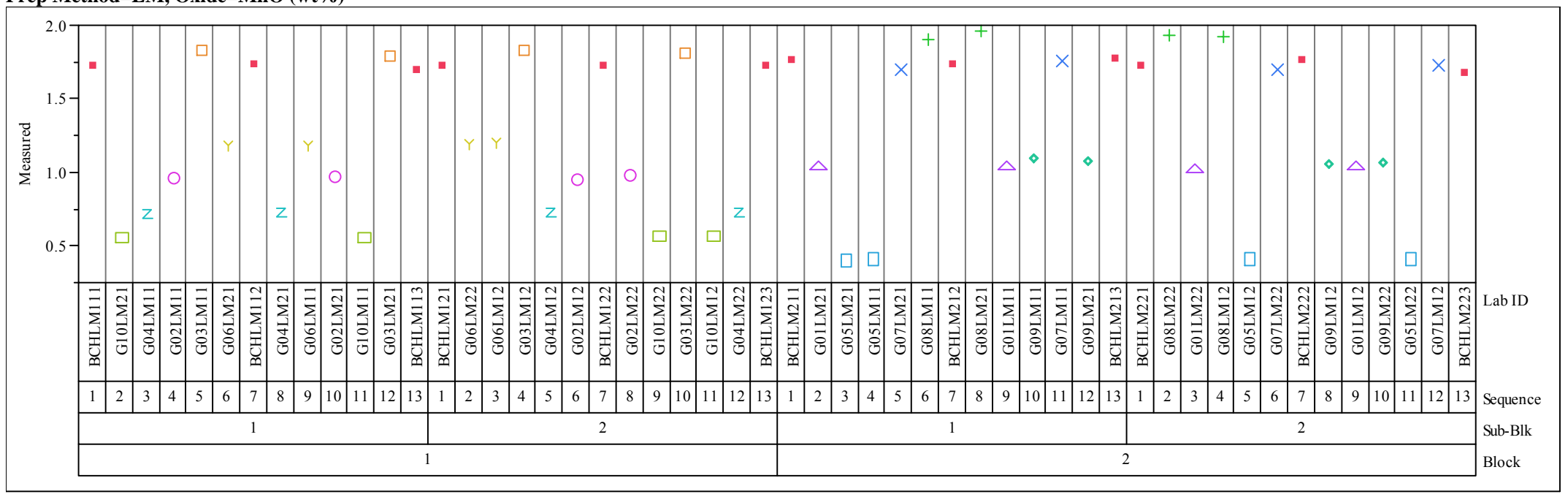

Prep Method=LM, Oxide=Na2O (wt \%)

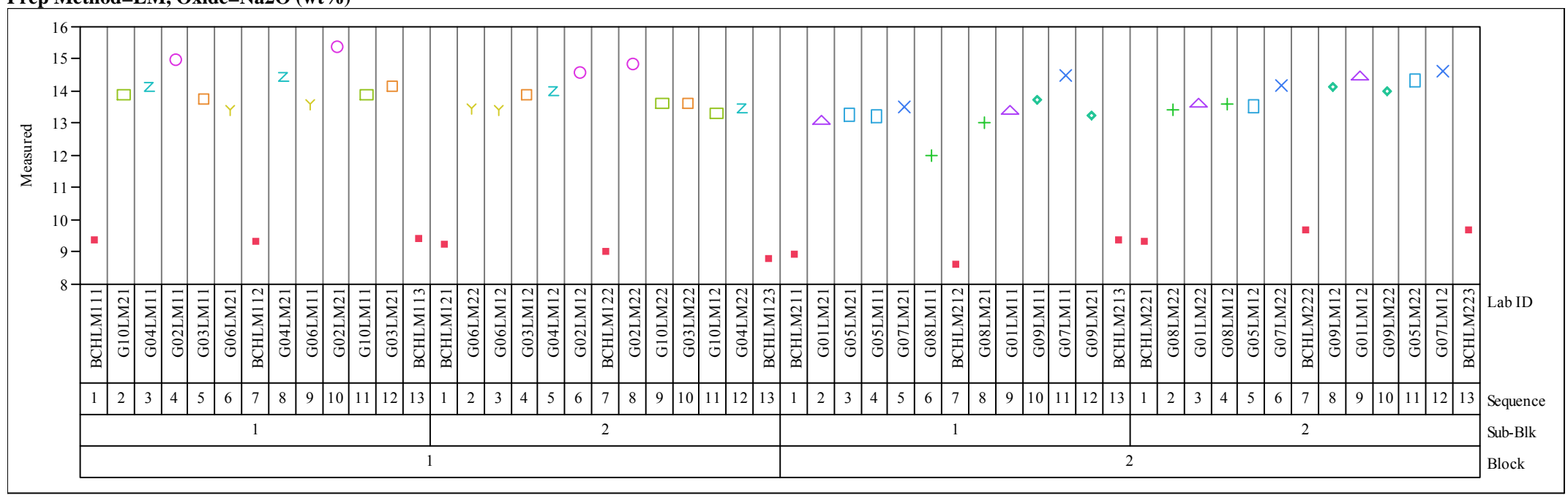


Exhibit A-1. Measurements in Analytical Sequence for the KT07-Series by Preparation Method by Oxide. (continued) Prep Method=LM, Oxide=Nb2O5 (wt\%)

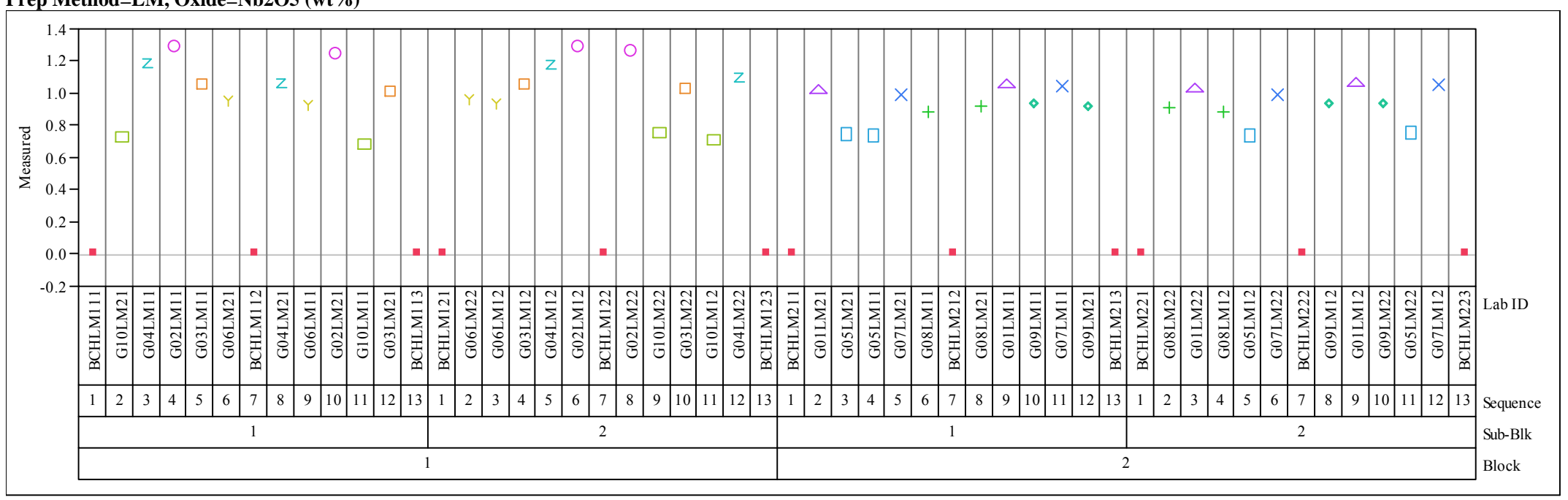

Prep Method=LM, Oxide=NiO (wt \%)

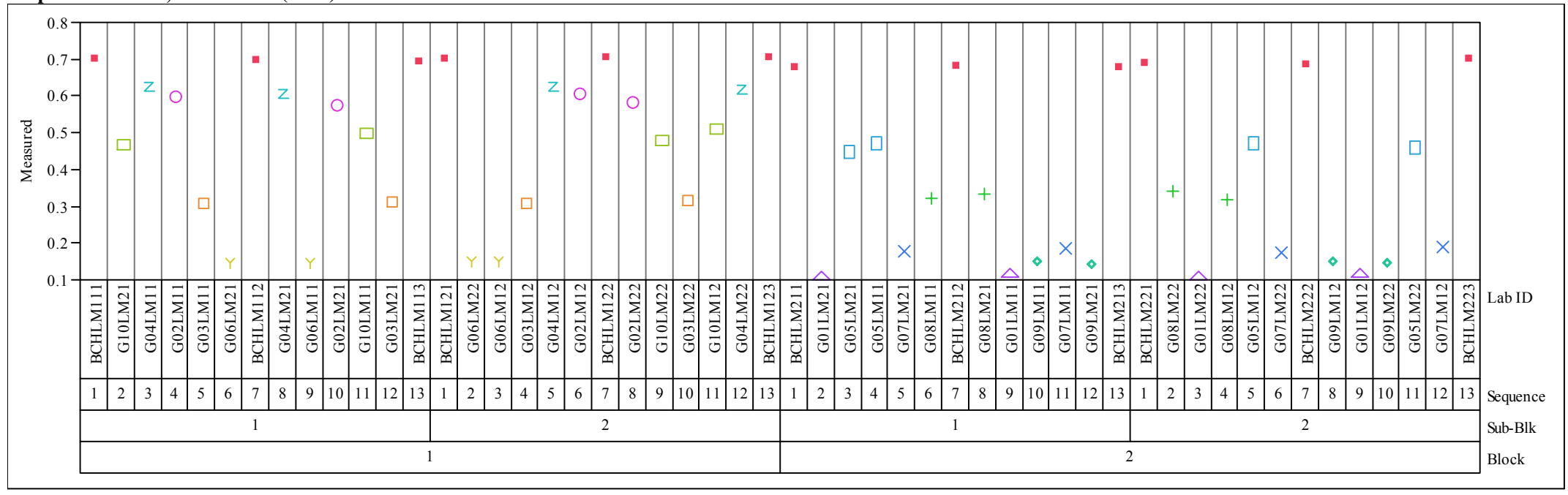




\section{Exhibit A-1. Measurements in Analytical Sequence for the KT07-Series by Preparation Method by Oxide. (continued)} Prep Method=LM, Oxide=PbO (wt \%)

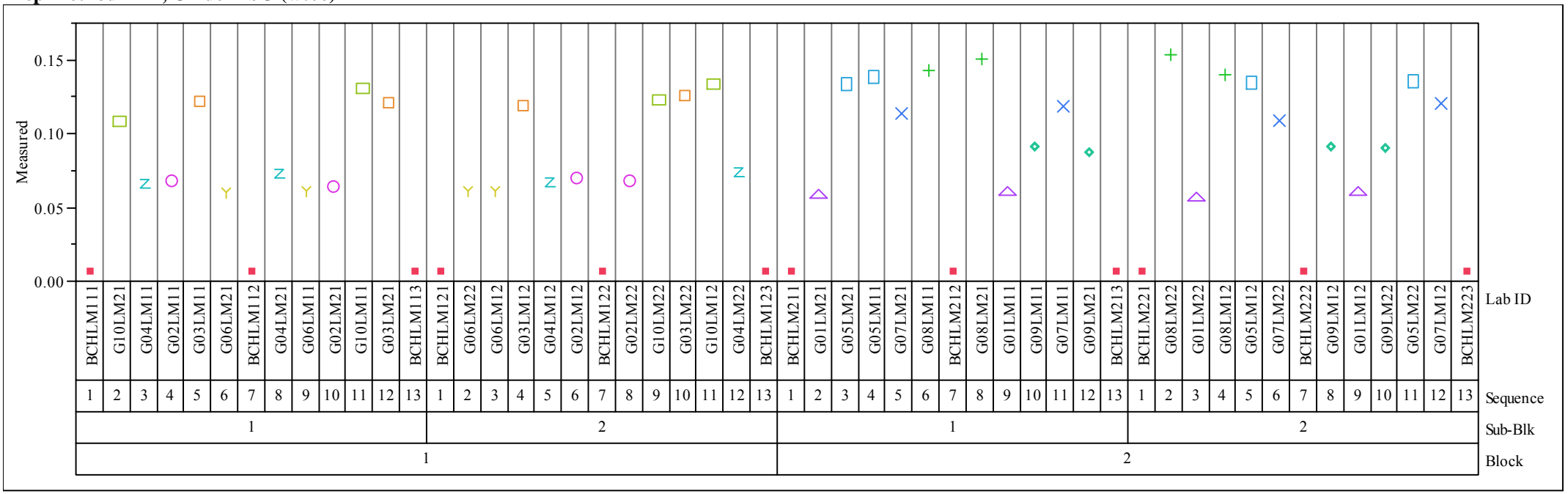

Prep Method=LM, Oxide=SiO2 (wt \%)

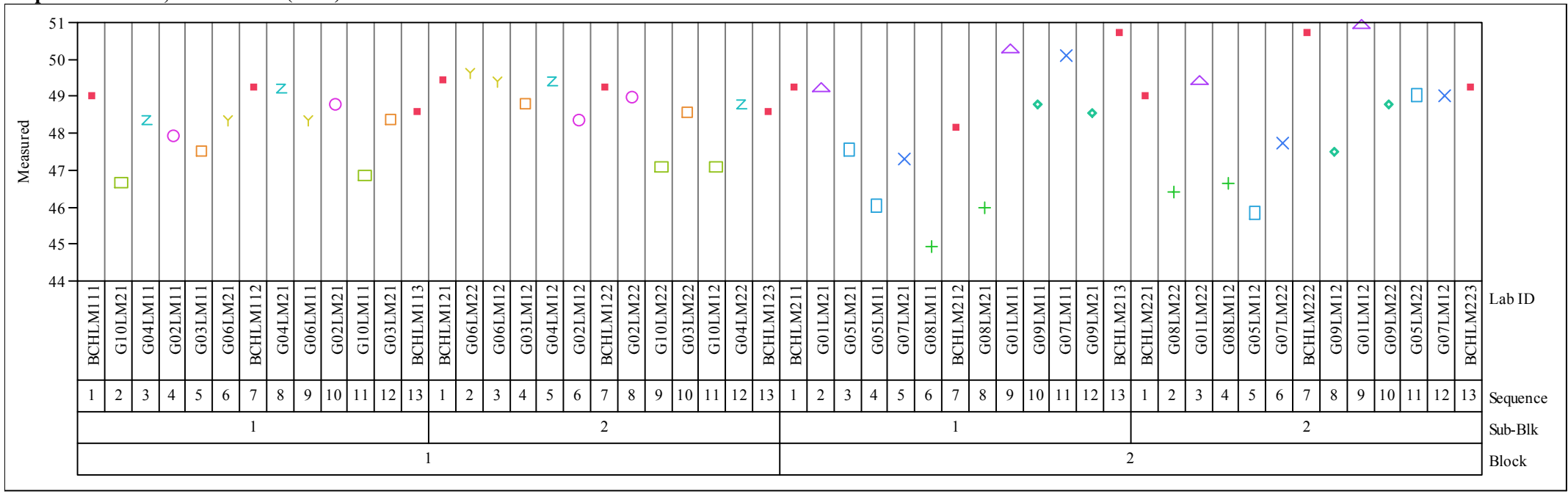


Exhibit A-1. Measurements in Analytical Sequence for the KT07-Series by Preparation Method by Oxide. (continued) Prep Method=LM, Oxide=SO4 (wt\%)

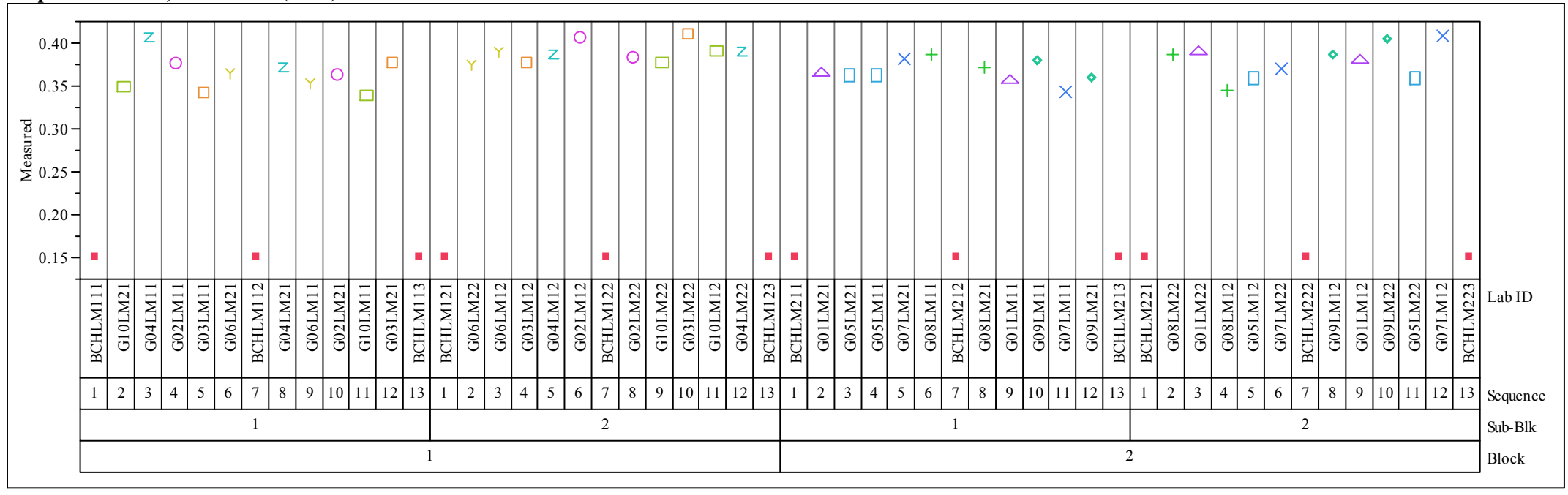

Prep Method=LM, Oxide=TiO2 (wt\%)

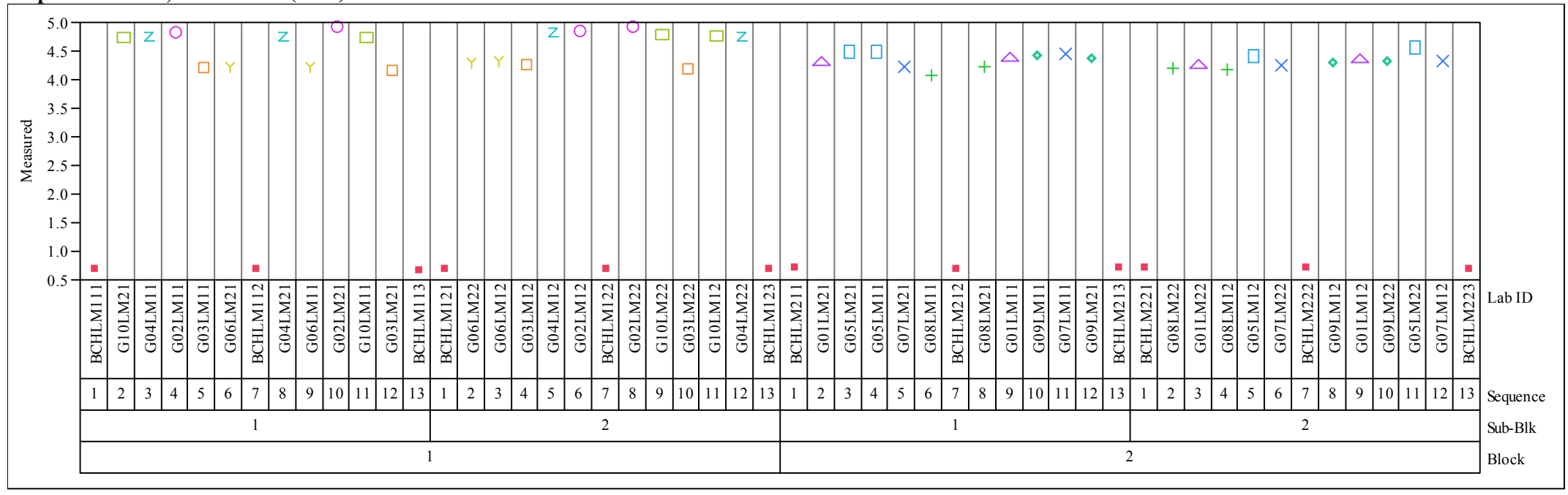


Exhibit A-1. Measurements in Analytical Sequence for the KT07-Series by Preparation Method by Oxide. (continued) Prep Method=LM, Oxide=ZnO (wt\%)

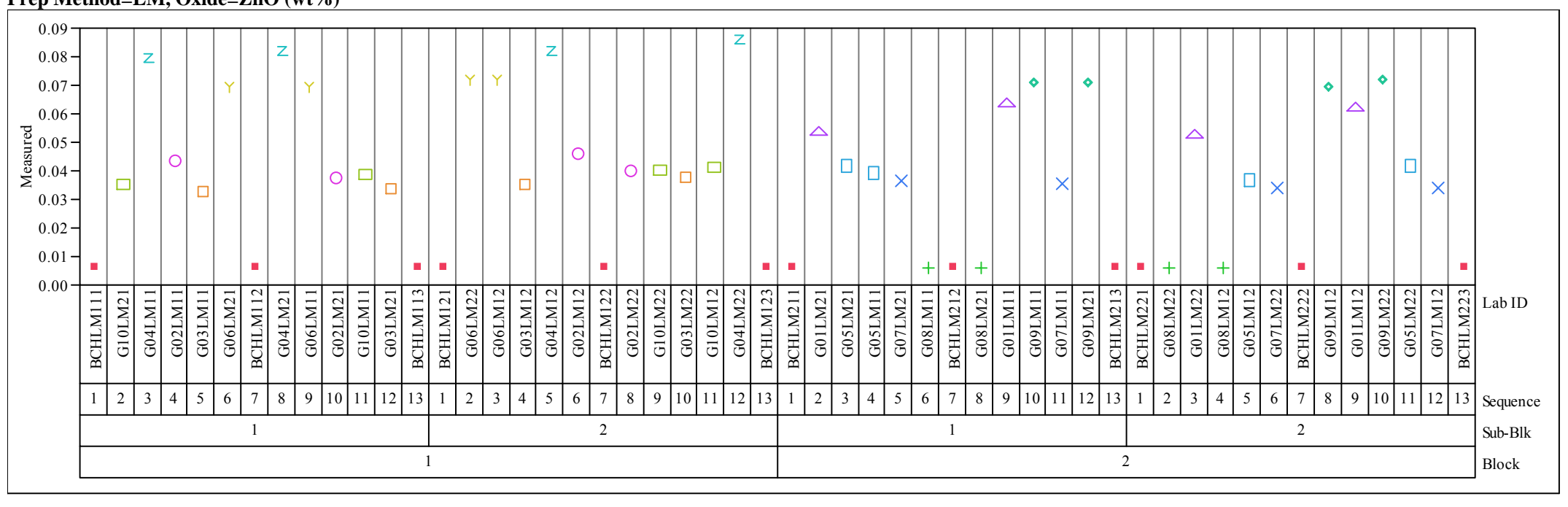

Prep Method=LM, Oxide=ZrO2 (wt\%)

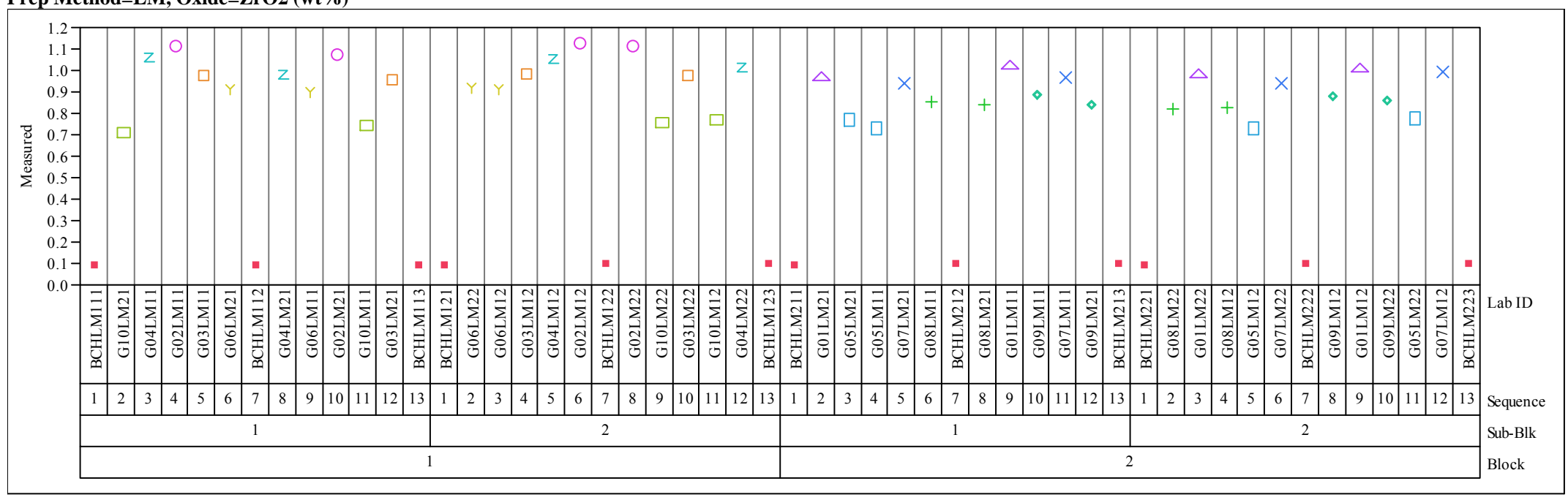


Exhibit A-1. Measurements in Analytical Sequence for the KT07-Series by Preparation Method by Oxide. (continued) Prep Method=PF, Oxide=B2O3 (wt \%)

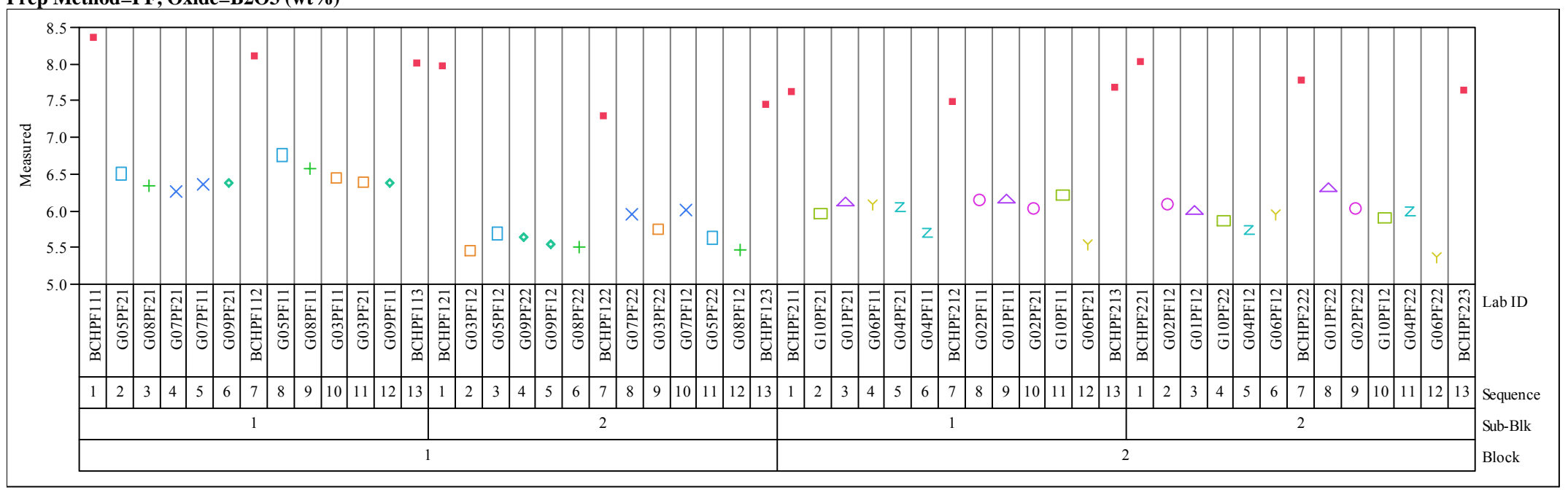

Prep Method=PF, Oxide=Li2O (wt\%)

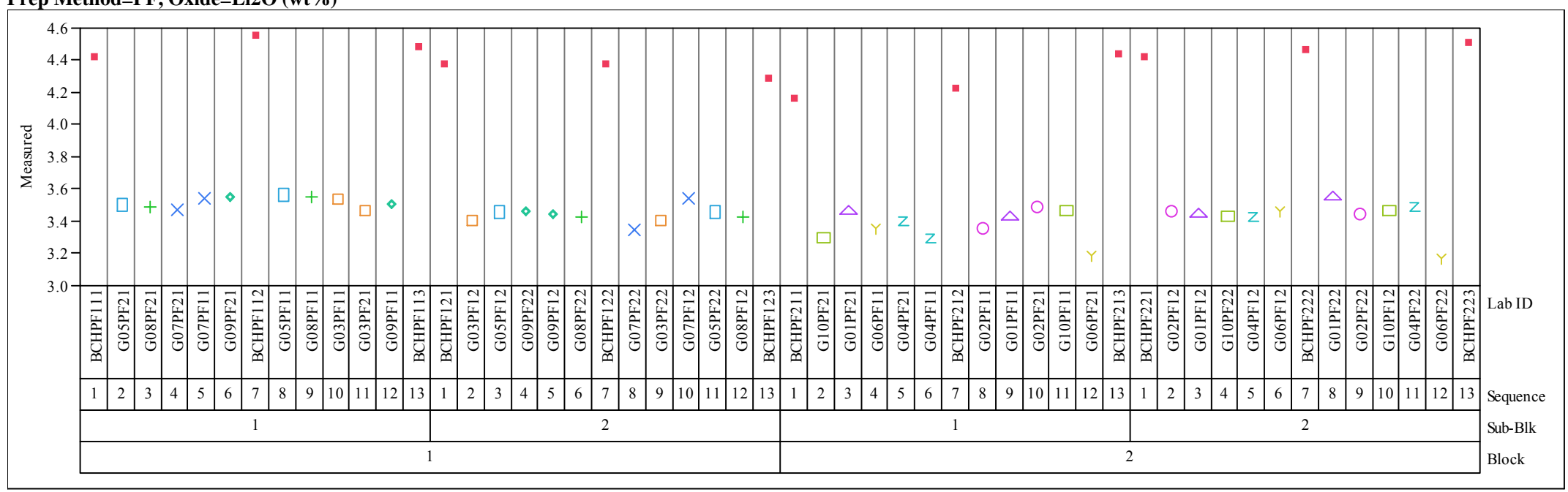




\section{Exhibit A-2. Measurements for Each KT7-Series Glass ID by Preparation Method by Oxide.}

Prep Method=LM, Oxide=Al2O3 (wt \%)

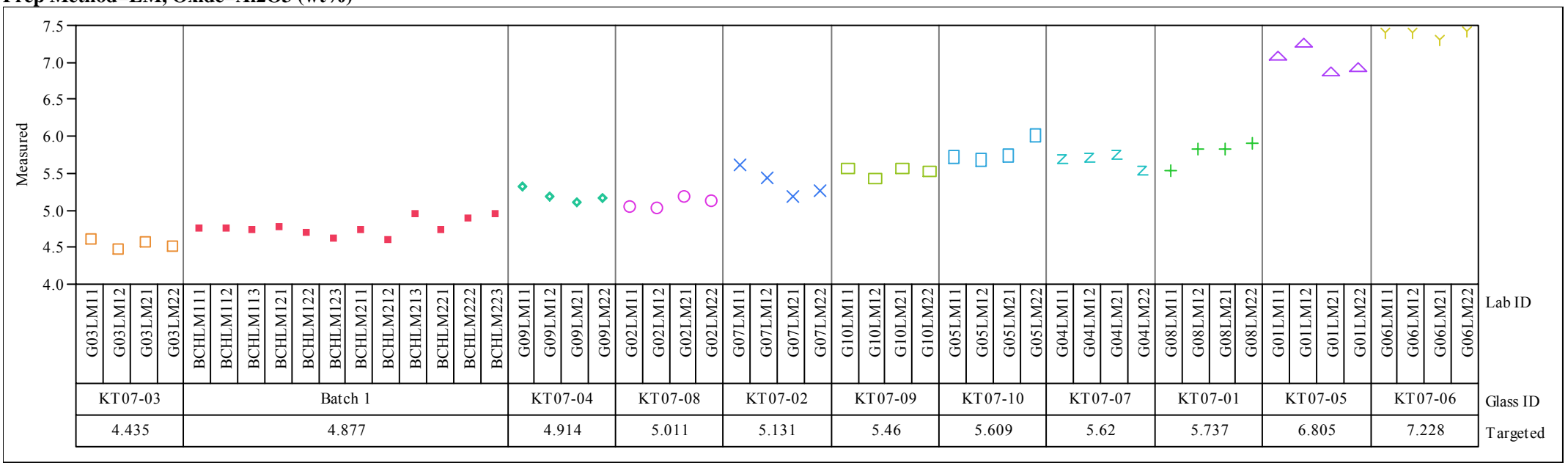

$=$ Prep Method=LM, Oxide=BaO (wt \%)

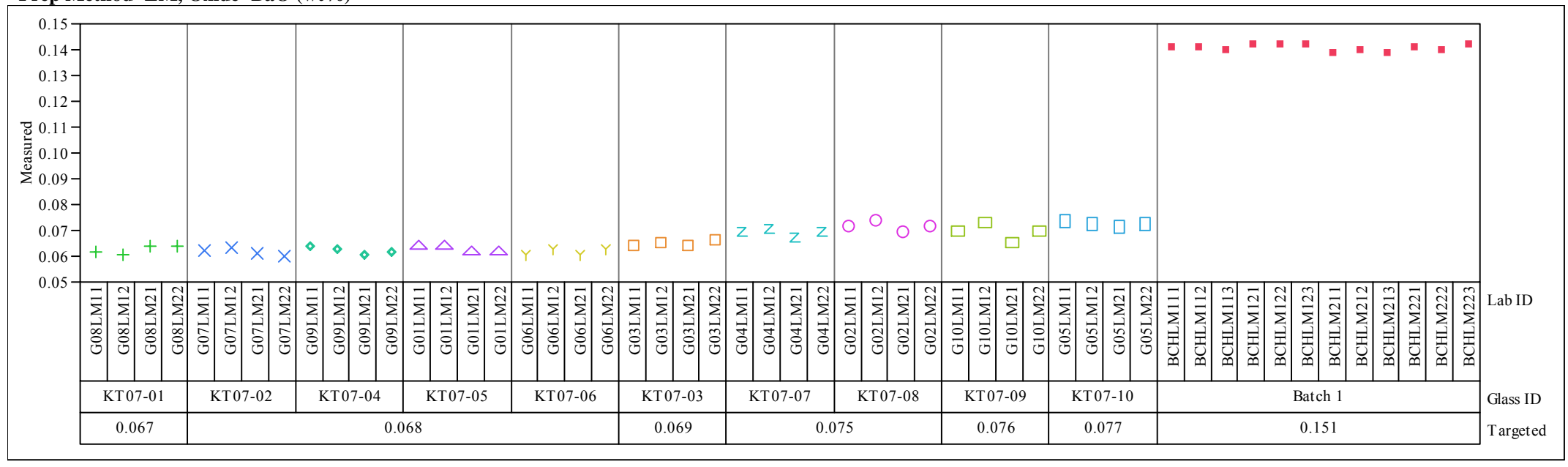




\section{Exhibit A-2. Measurements for Each KT7-Series Glass ID by Preparation Method by Oxide. (continued)}

Prep Method $=$ LM, Oxide $=\mathrm{CaO}(\mathrm{wt} \%)$

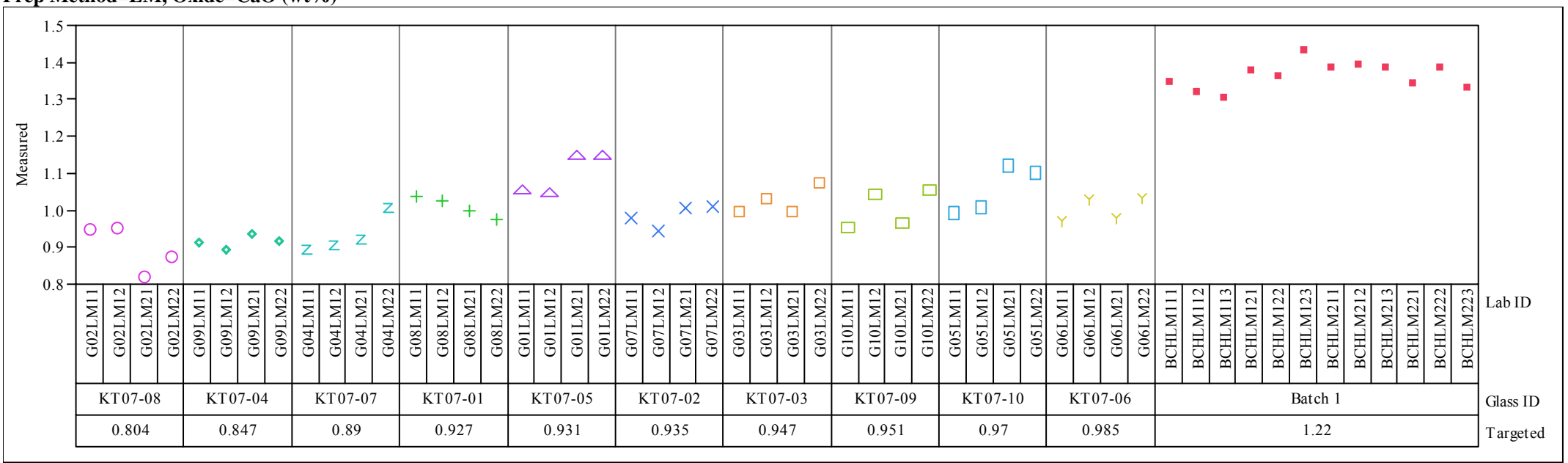

Prep Method=LM, Oxide=Ce2O3 (wt \%)

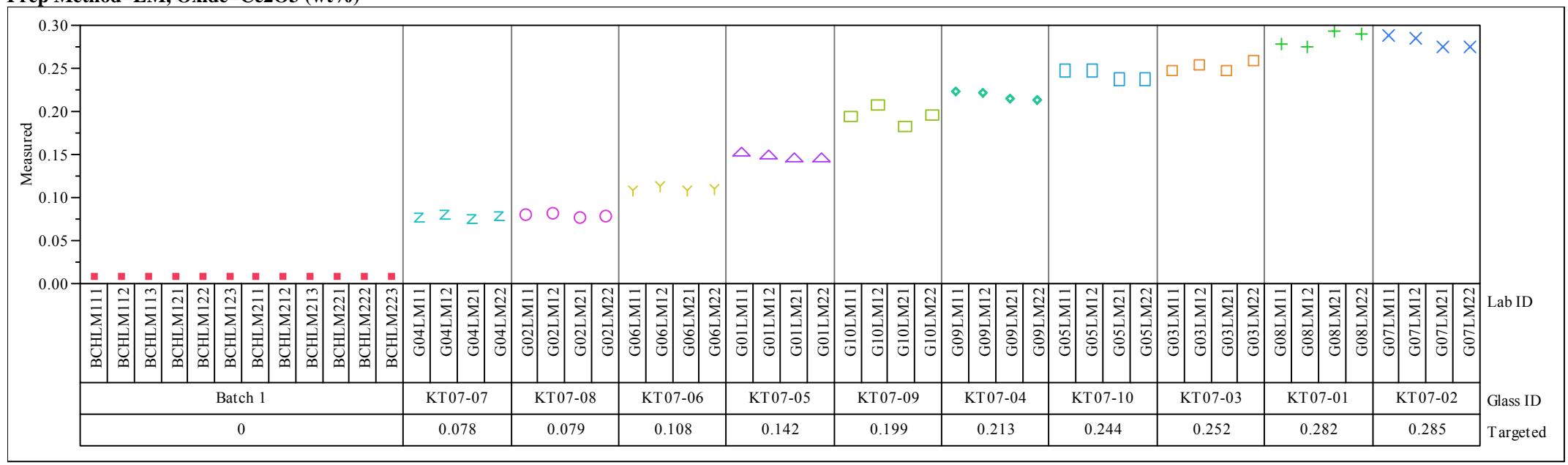




\section{Exhibit A-2. Measurements for Each KT7-Series Glass ID by Preparation Method by Oxide. (continued)}

Prep Method=LM, Oxide $=$ Cr2O3 $(w t \%)$

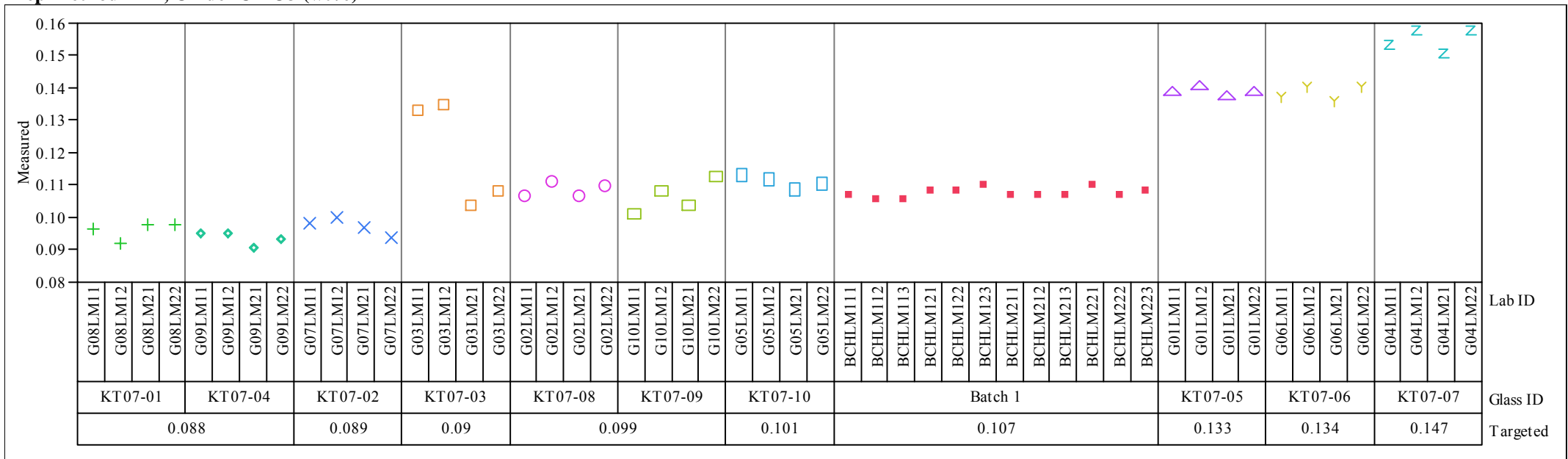

Prep Method=LM, Oxide=CuO (wt \%)

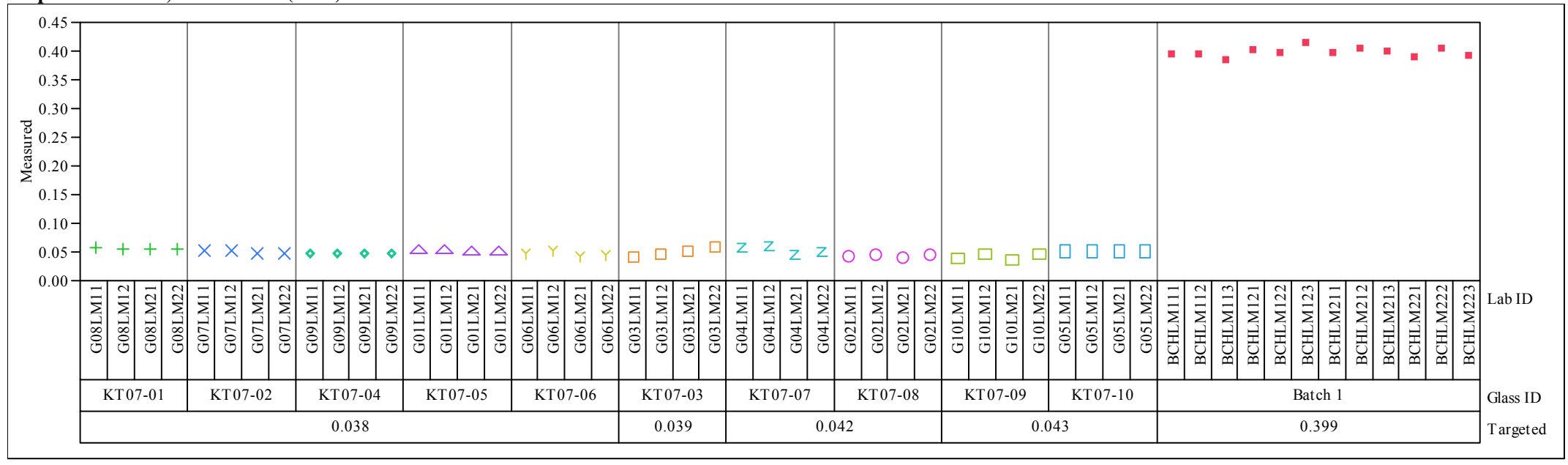




\section{Exhibit A-2. Measurements for Each KT7-Series Glass ID by Preparation Method by Oxide. (continued)}

Prep Method=LM, Oxide=Fe2O3 (wt \%)

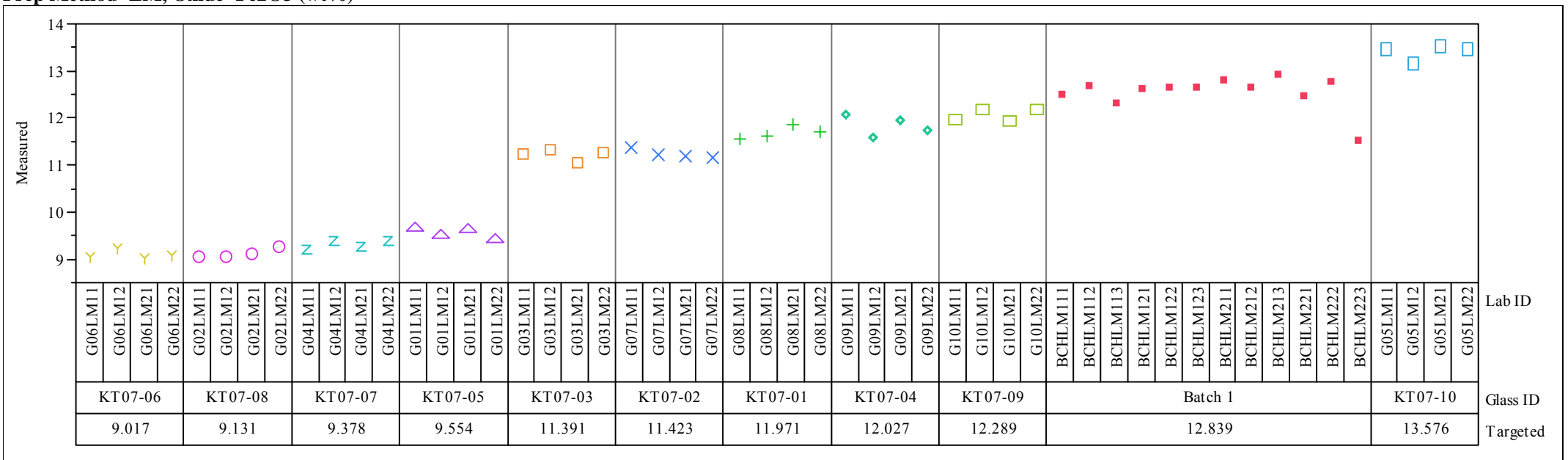

Prep Method=LM, Oxide=K2O (wt \%)

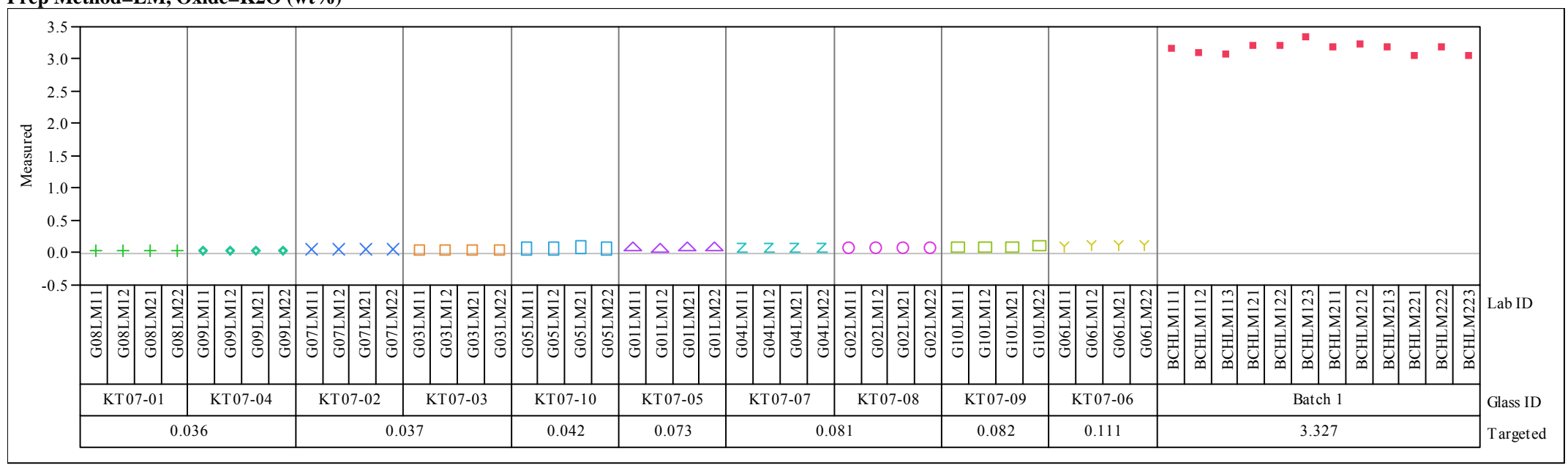




\section{Exhibit A-2. Measurements for Each KT7-Series Glass ID by Preparation Method by Oxide. (continued)}

\section{Prep Method=LM, Oxide=La2O3 (wt\%)}

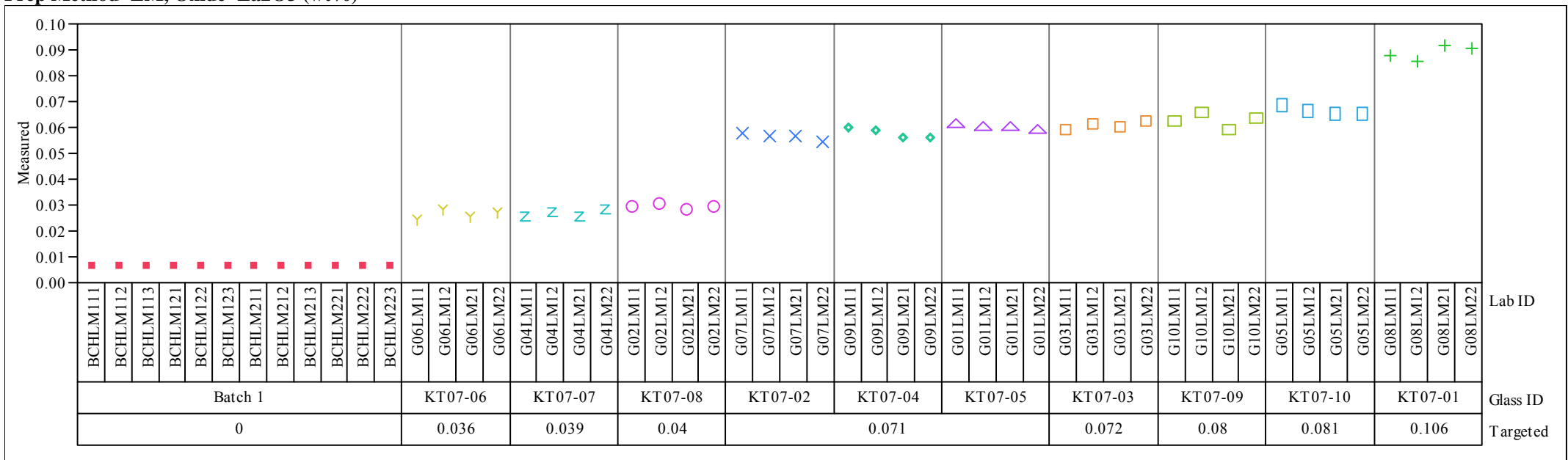

Prep Method=LM, Oxide=MgO (wt \%)

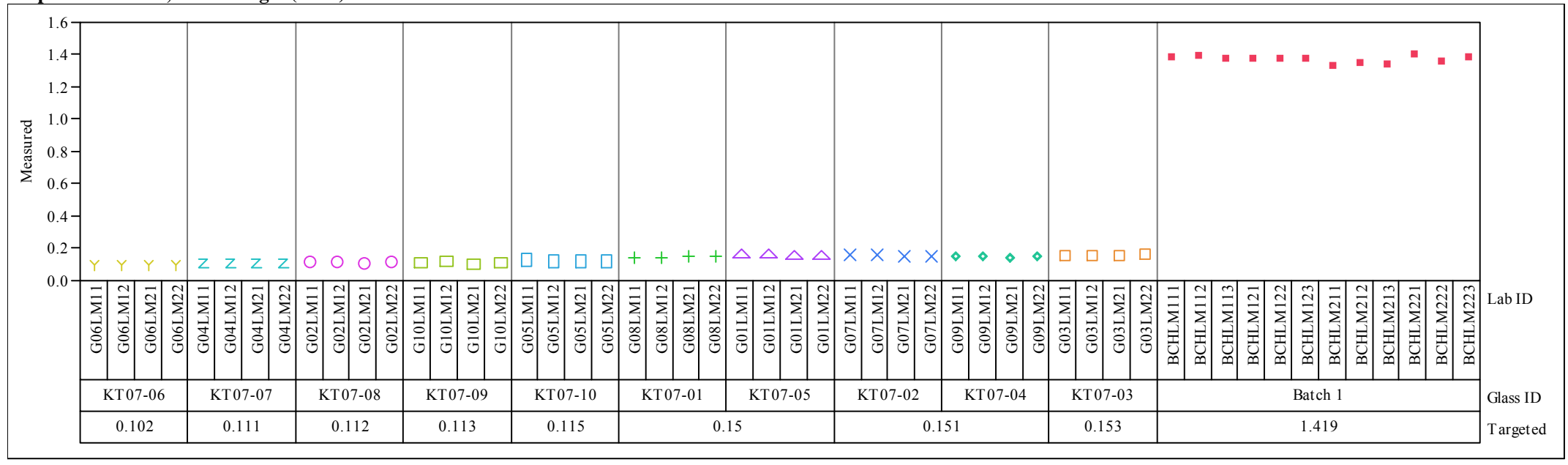




\section{Exhibit A-2. Measurements for Each KT7-Series Glass ID by Preparation Method by Oxide. (continued)}

Prep Method=LM, Oxide=MnO (wt\%)

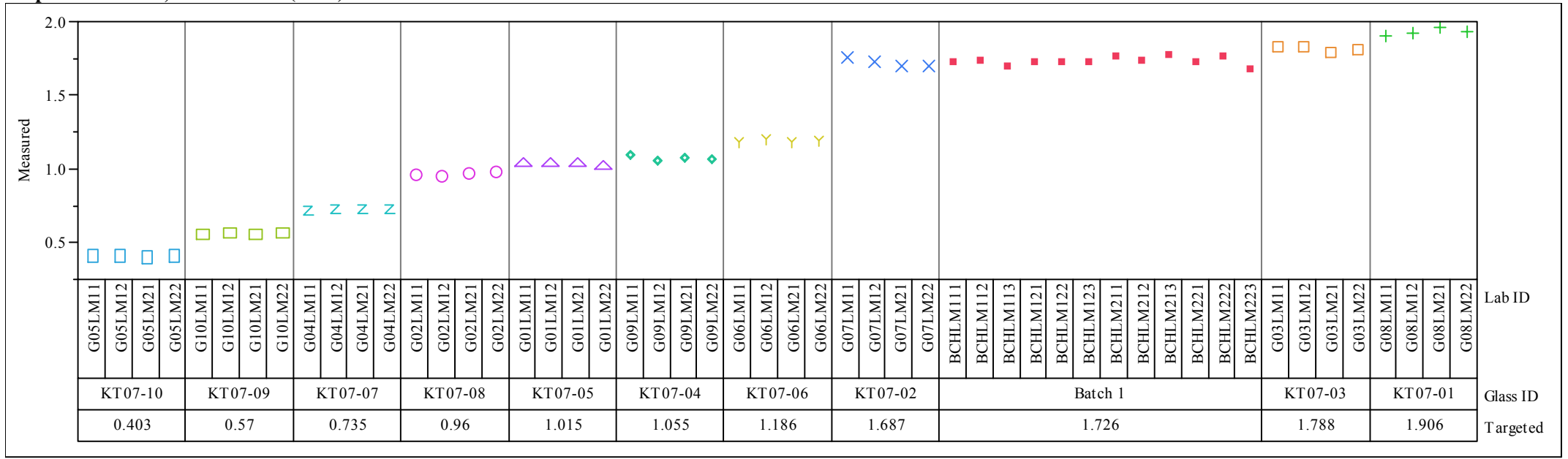

Prep Method=LM, Oxide=Na2O (wt\%)

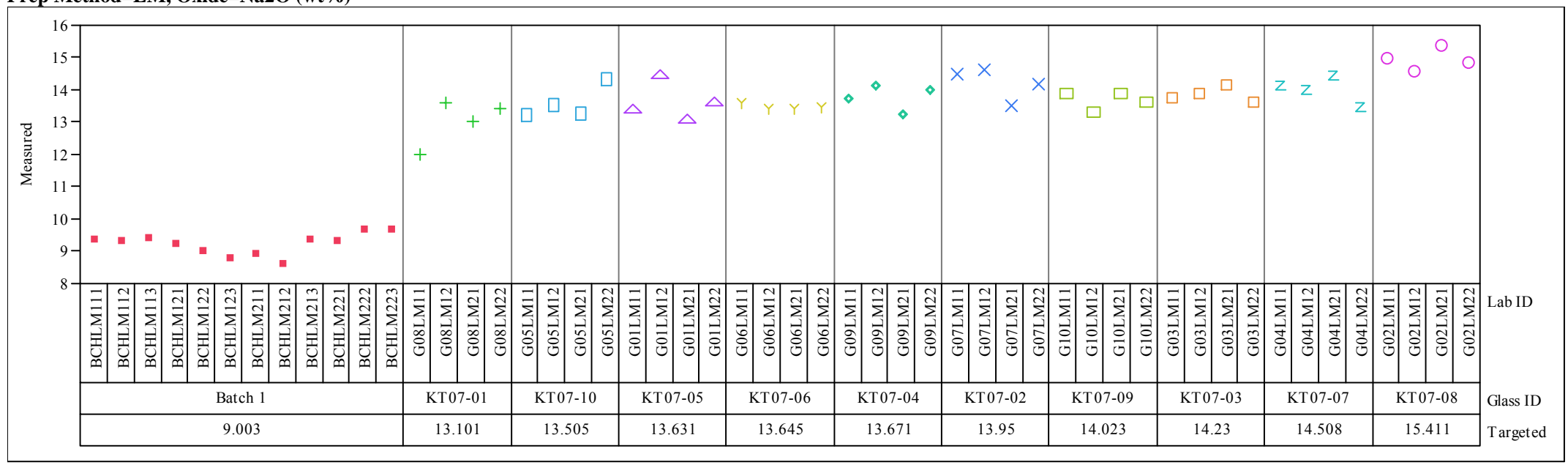




\section{Exhibit A-2. Measurements for Each KT7-Series Glass ID by Preparation Method by Oxide. (continued)}

Prep Method=LM, Oxide=Nb2O5 (wt\%)

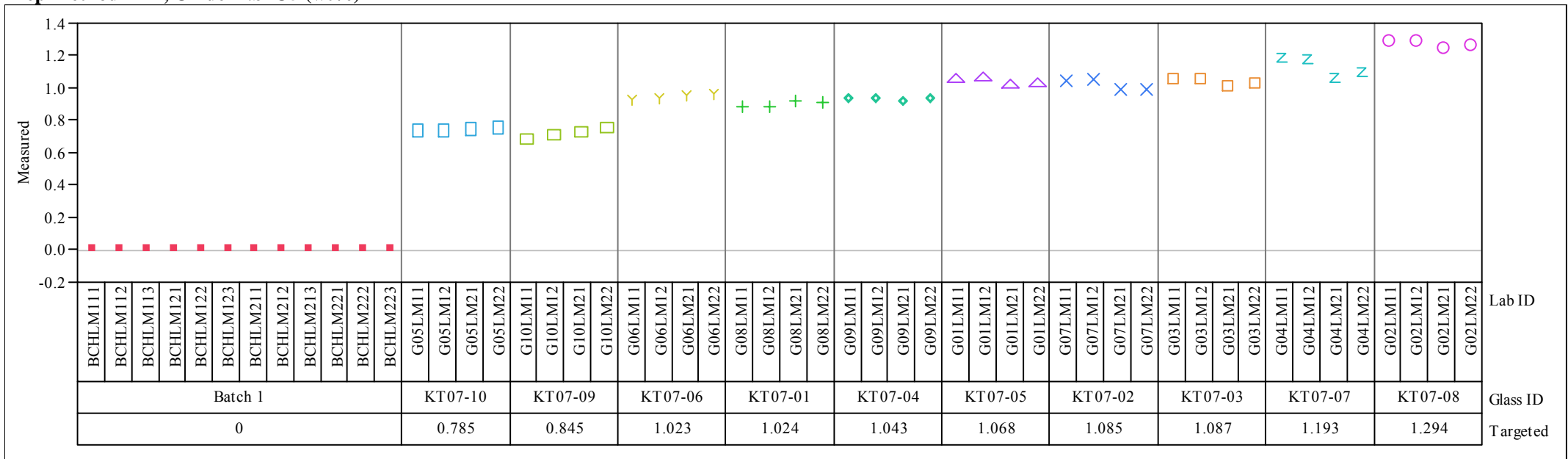

Prep Method=LM, Oxide=NiO (wt \%)

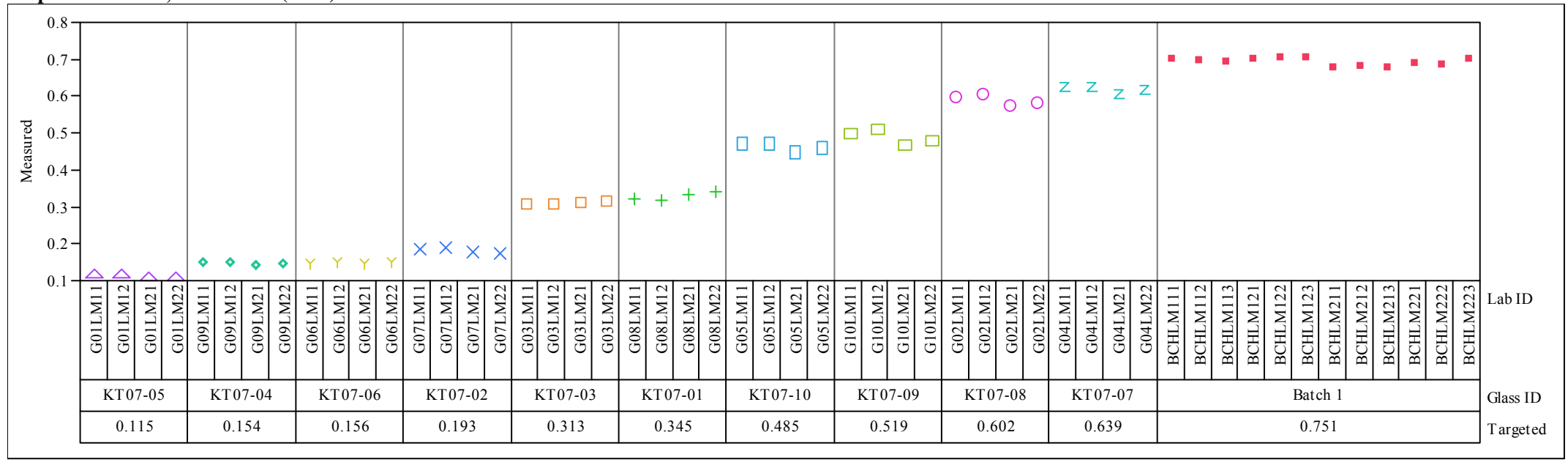




\section{Exhibit A-2. Measurements for Each KT7-Series Glass ID by Preparation Method by Oxide. (continued)}

Prep Method=LM, Oxide=PbO (wt \%)

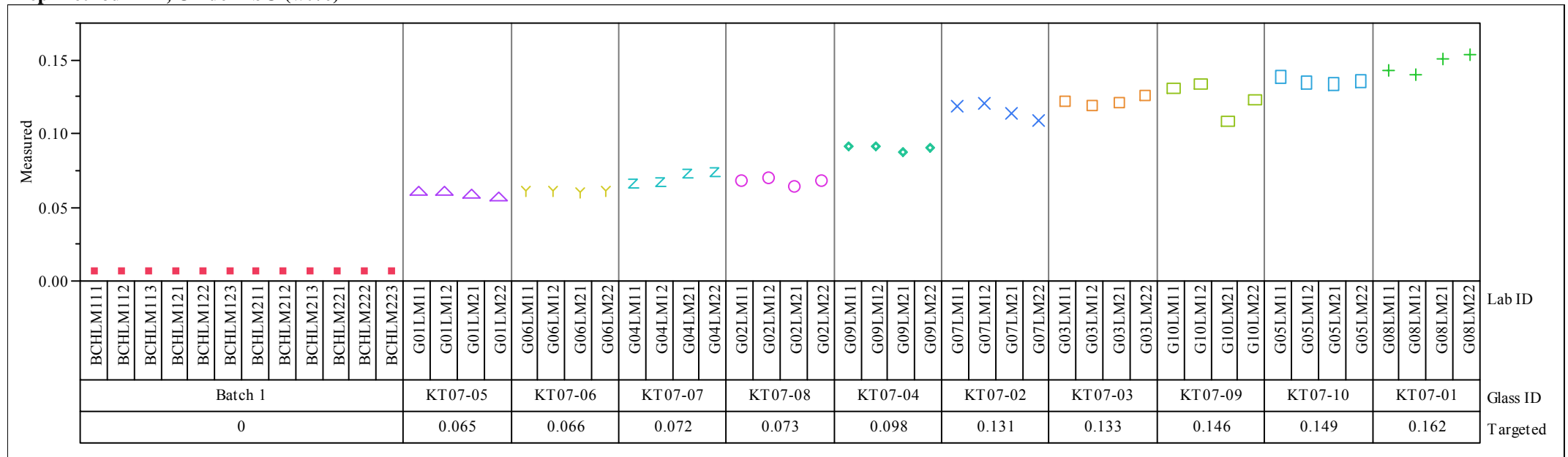

Prep Method=LM, Oxide=SiO2 (wt\%)

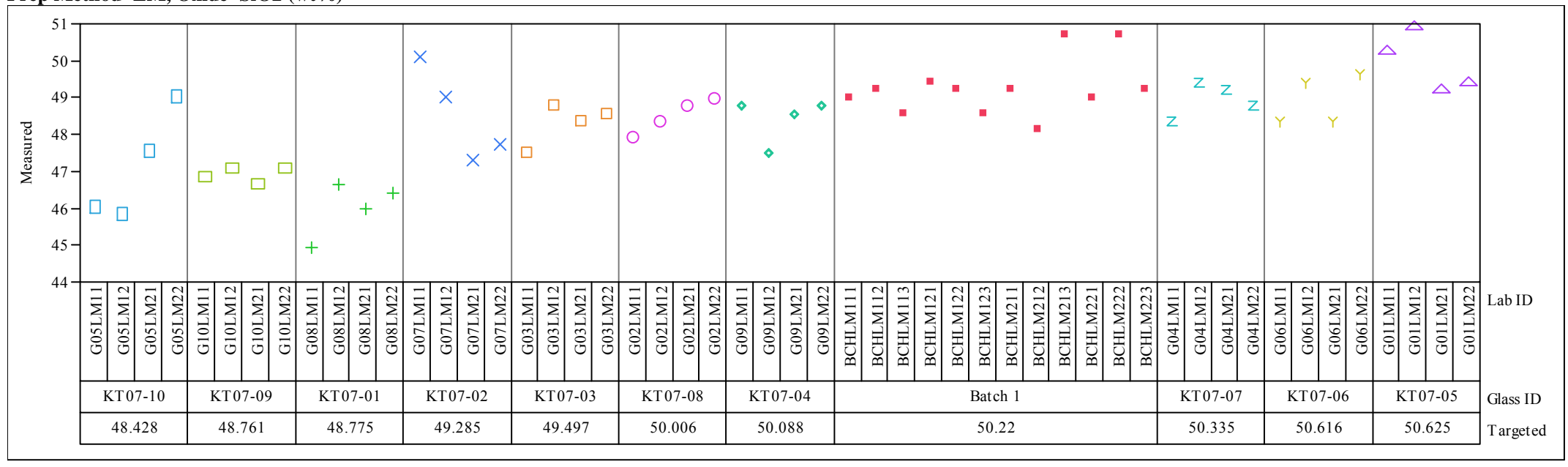




\section{Exhibit A-2. Measurements for Each KT7-Series Glass ID by Preparation Method by Oxide. (continued)}

Prep Method=LM, Oxide=SO4 (wt\%)

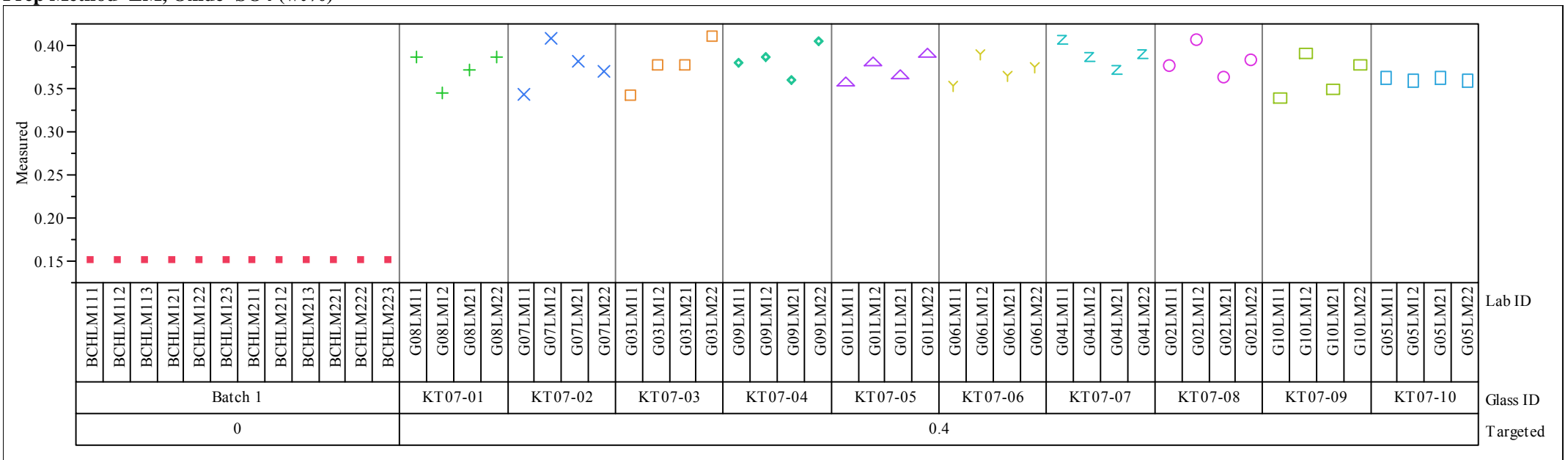

Prep Method=LM, Oxide=TiO2 (wt\%)

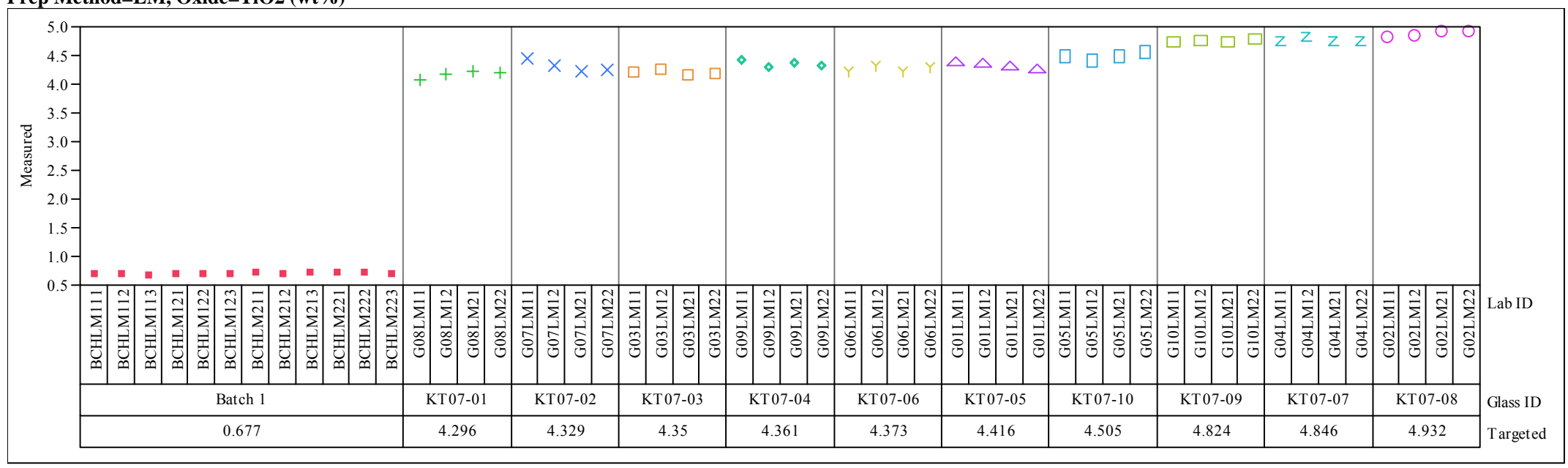




\section{Exhibit A-2. Measurements for Each KT7-Series Glass ID by Preparation Method by Oxide. (continued)}

Prep Method=LM, Oxide=ZnO (wt\%)

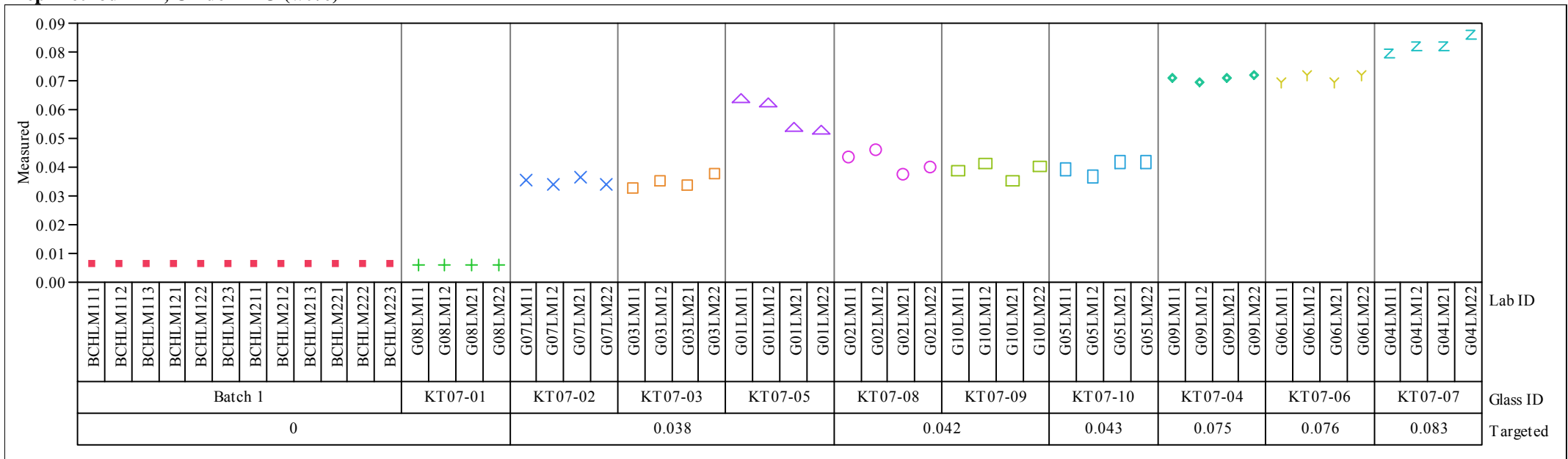

Prep Method=LM, Oxide=ZrO2 (wt \%)

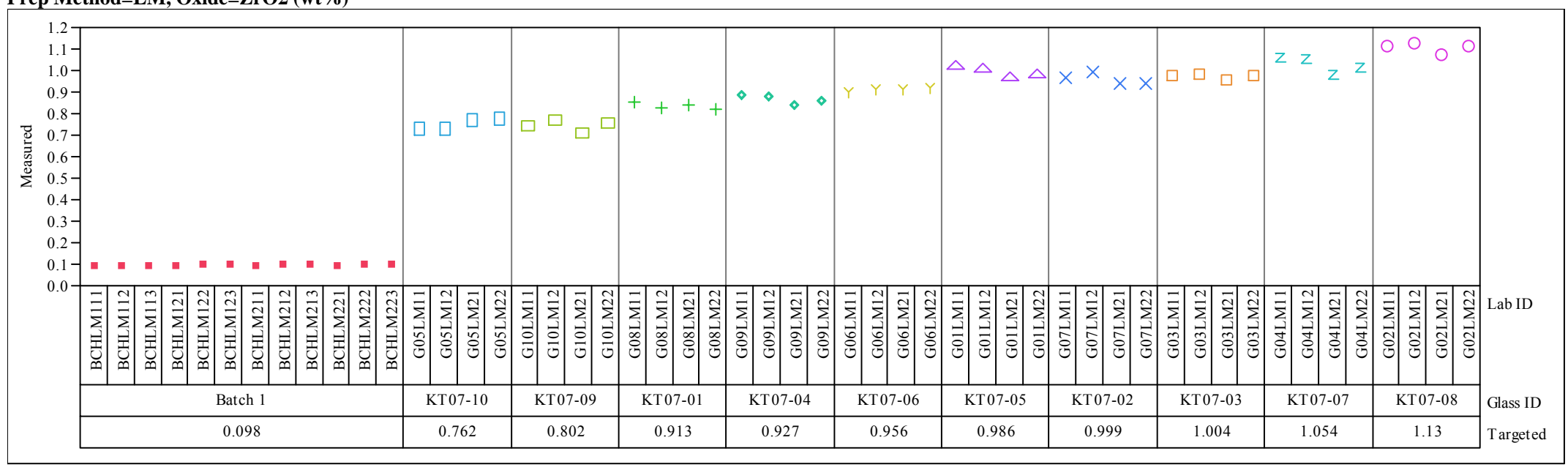




\section{Exhibit A-2. Measurements for Each KT7-Series Glass ID by Preparation Method by Oxide. (continued)}

Prep Method=PF, Oxide=B2O3 (wt \%)
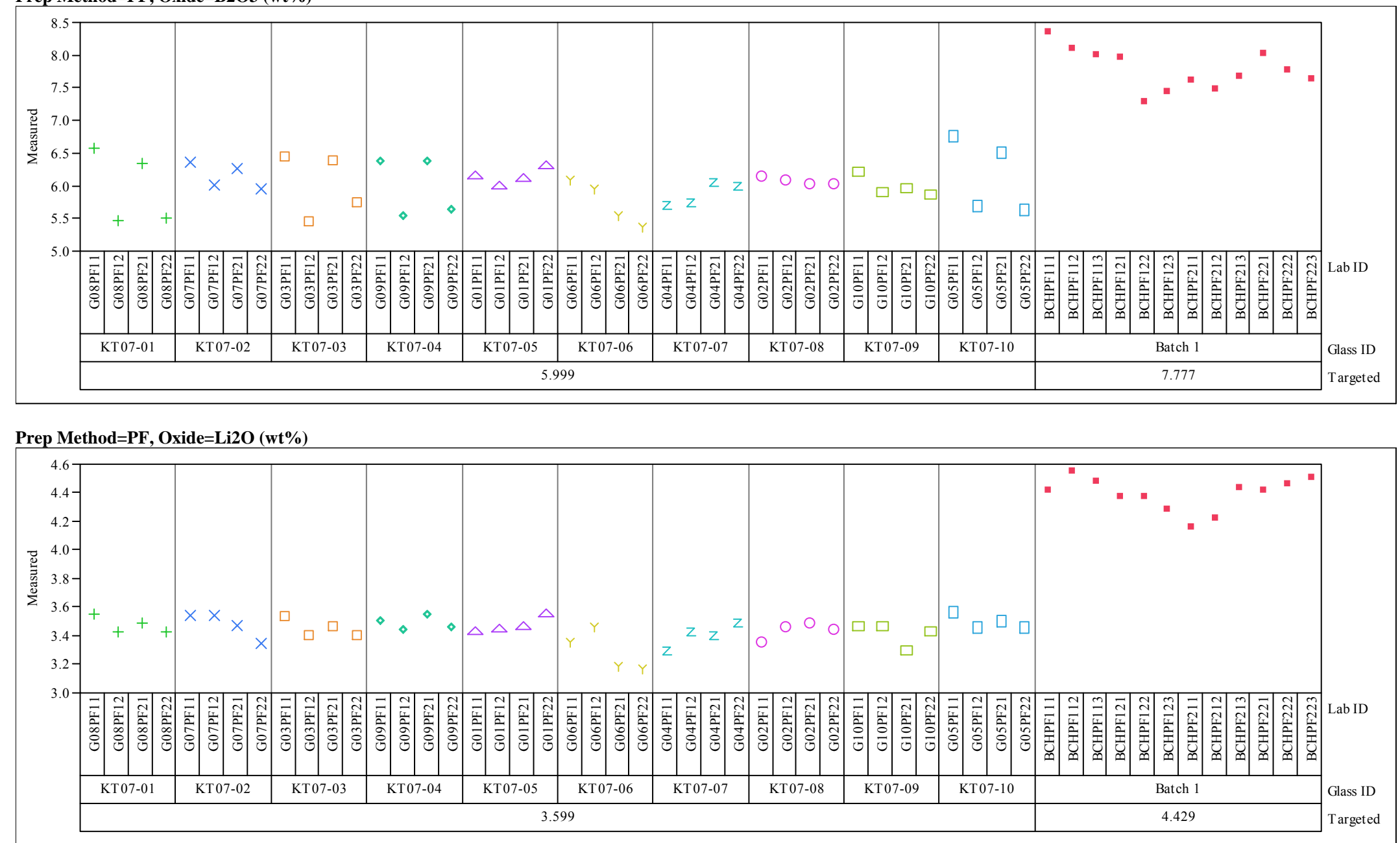
Exhibit A-3. Statistical Evaluation of the ICP Calibration Effects from the KT07 Batch 1 Results by Oxide.

\begin{tabular}{|c|c|}
\hline $\begin{array}{l}\begin{array}{l}\text { Oneway Analysis of Measured By Series/Blk/Sub-Blk Series=KT7, Prep Method=LM, Oxide=Al2O3 } \\
\text { (wt\%), Targeted }=4.877\end{array} \\
\text { (w) The }\end{array}$ & $\begin{array}{l}\text { Oneway Analysis of Measured By Series/Blk/Sub-Blk Series=KT7, Prep Method=LM, Oxide=BaO (wt\%), } \\
\text { Targeted }=0.151\end{array}$ \\
\hline 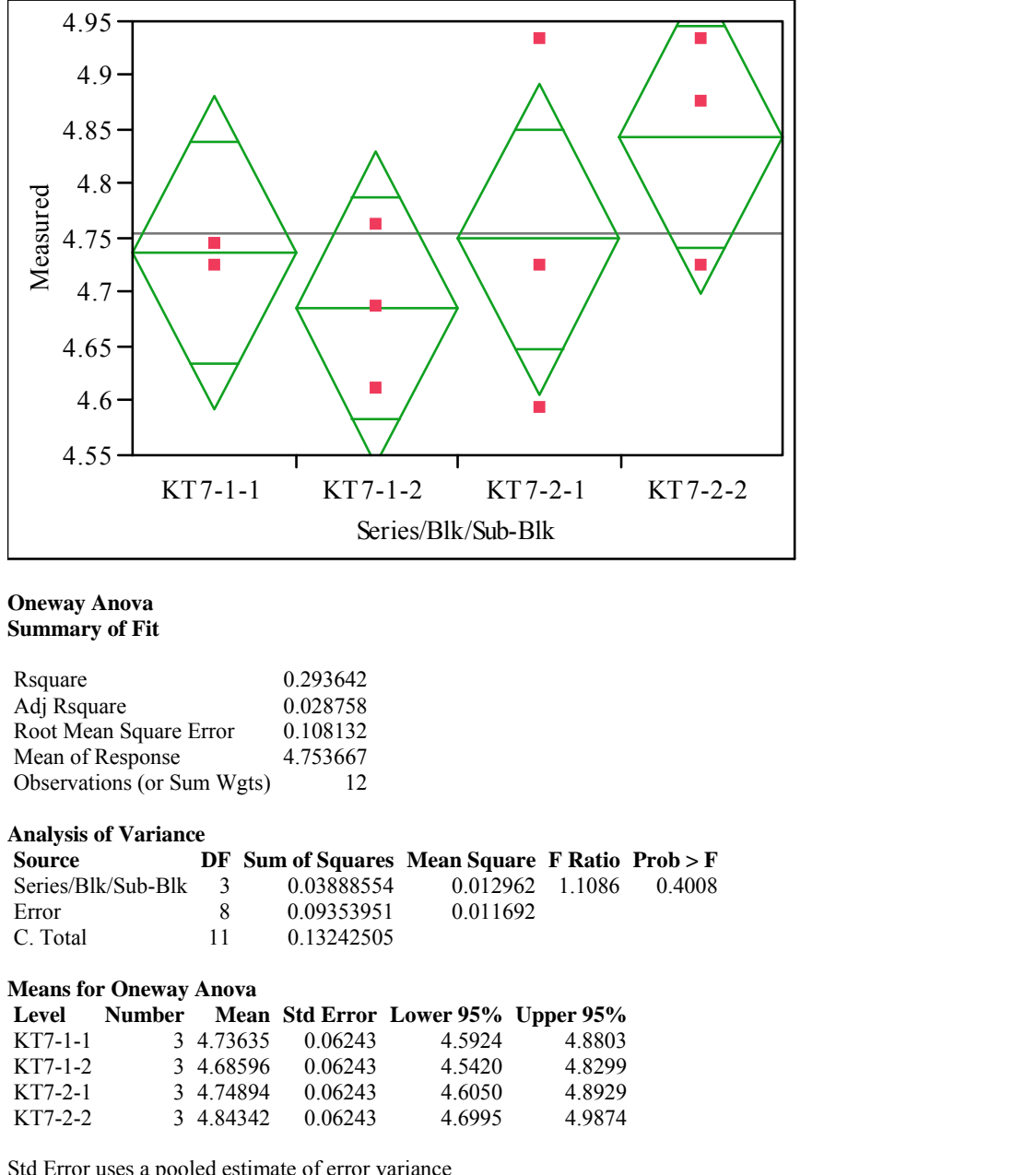 & 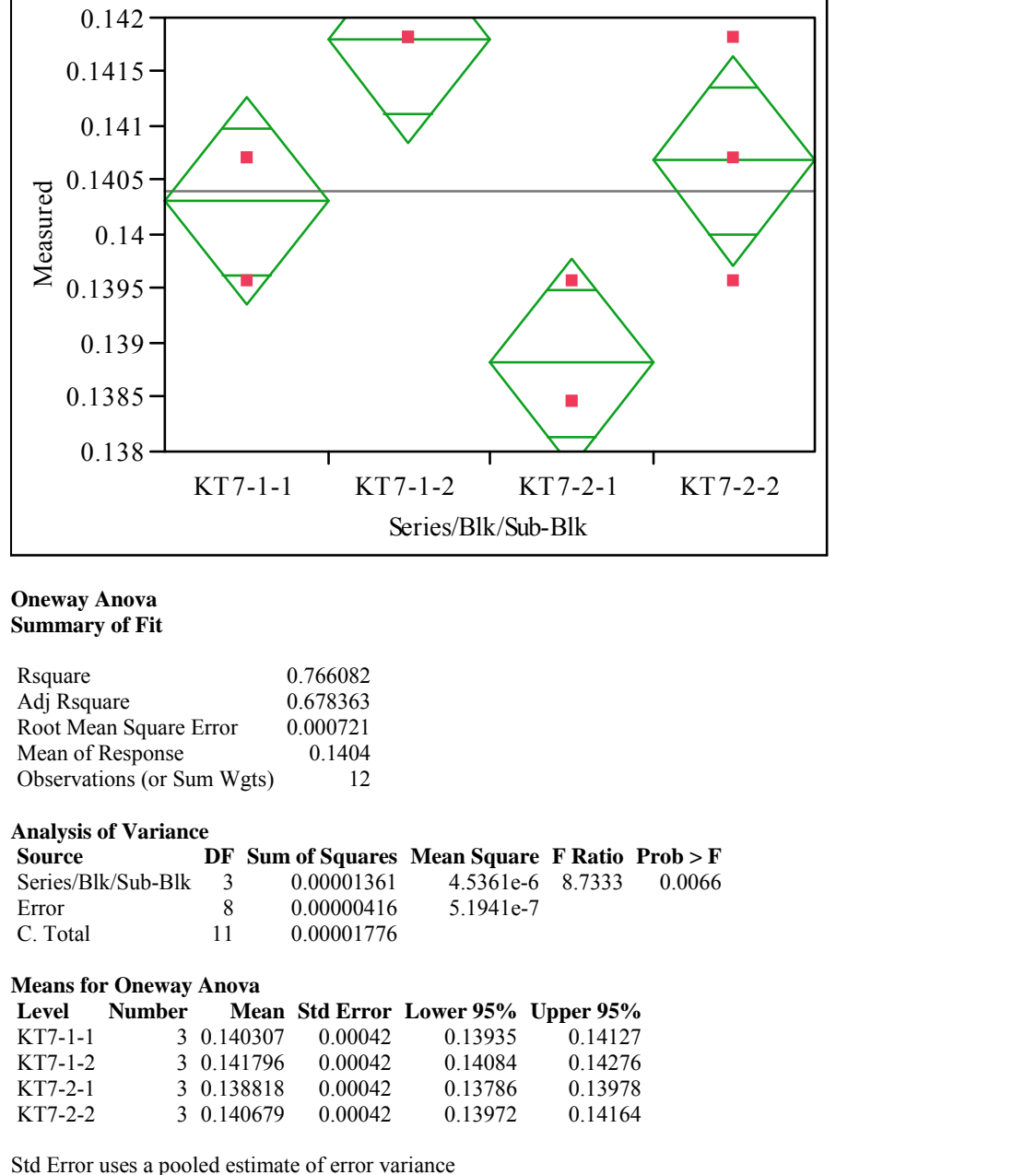 \\
\hline
\end{tabular}


Exhibit A-3. Statistical Evaluation of the ICP Calibration Effects from the KT07 Batch 1 Results by Oxide. (continued)

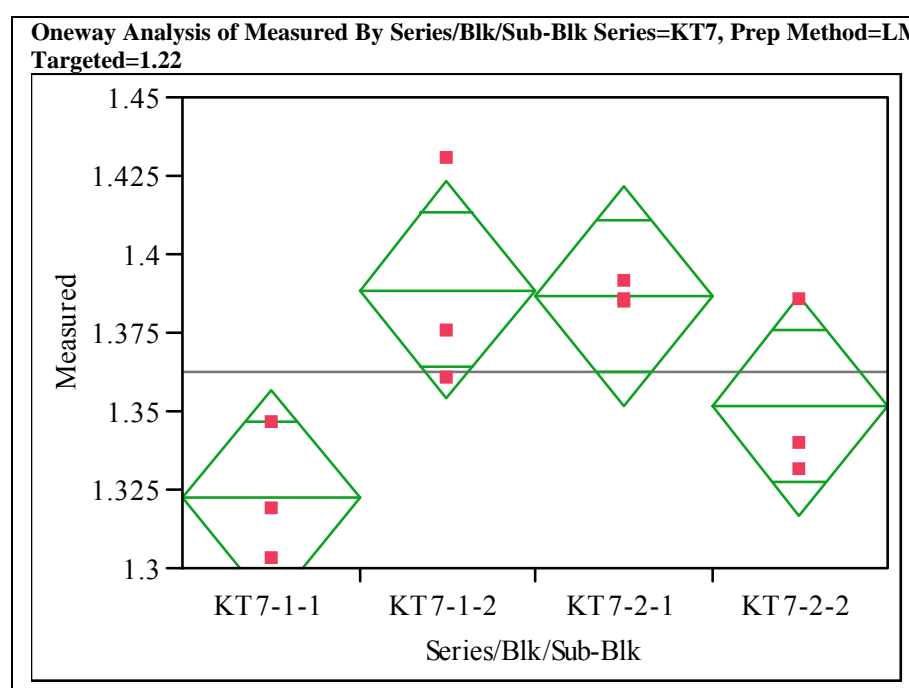

Oneway Anova

Summary of Fit

Adj Rsquare $\quad 0.623495$

Adj Rsquare $\quad 0.482306$

Root Mean Square Error $\quad 0.026039$

$\begin{array}{lr}\text { Mean of Response } & 1.362238 \\ \text { Observations (or Sum Wgts) } & 12\end{array}$

Analysis of Variance

Source DF Sum of Squares Mean Square F Ratio Prob $>$ F

$\begin{array}{lrrrrr}\text { Series/Blk/Sub-Blk } & 3 & 0.00898270 & 0.002994 & 4.4160 & 0.0413\end{array}$

Error $\quad 8 \quad 0.00542430$

C. Total

0.01440700

Means for Oneway Anova

Level Number Mean Std Error Lower 95\% Upper 95\%

$\begin{array}{llllll}\text { KT7-1-1 } & 3 & 1.32224 & 0.01503 & 1.2876 & 1.3569 \\ \text { KT7-1-2 } & 3 & 1.38847 & 0.01503 & 1.3538 & 1.4231\end{array}$

$\begin{array}{llllll}\text { KT7-1-2 } & 3 & 1.38847 & 0.01503 & 1.3538 & 1.423 \\ \text { KT7-2-1 } & 3 & 1.38661 & 0.01503 & 1.3519 & 1.4213\end{array}$

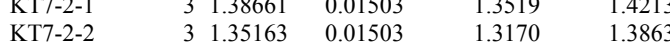

Std Error uses a pooled estimate of error variance

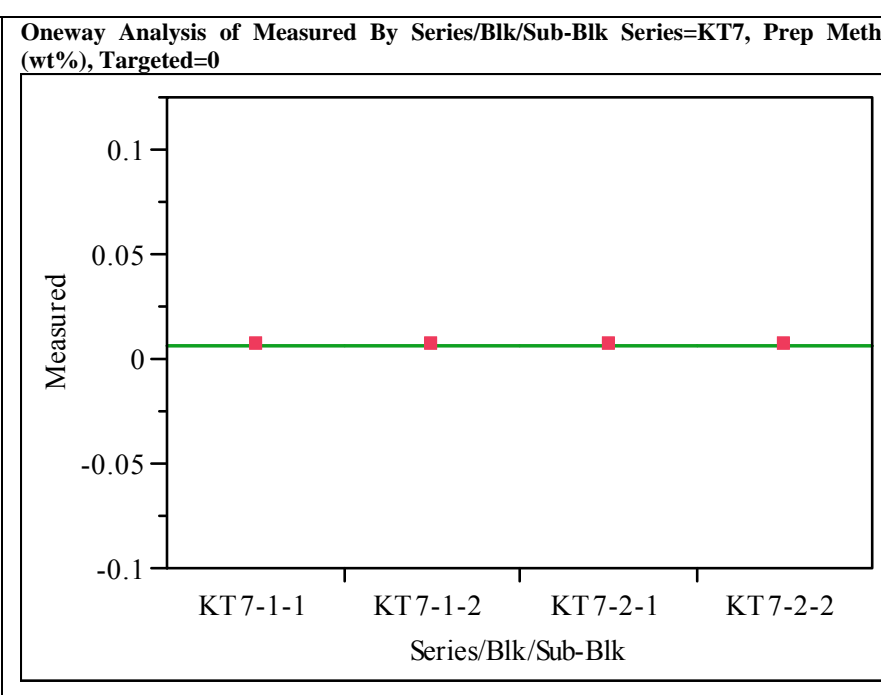

Oneway Anova

Summary of Fit

Rsquare

Adj Rsquare

Root Mean Square Error $\quad 0$

$\begin{array}{lr}\text { Mean of Response } & 0.005857 \\ \text { Observations (or Sum Wgts) } & 12\end{array}$

Analysis of Variance

Source DF Sum of Squares Mean Square F Ratio Prob $>$ F

$\begin{array}{lrrr}\text { Series/Blk/Sub-Blk } & 3 & 0 & 0 \\ \text { Error } & 8 & 0 & 0\end{array}$

$\begin{array}{rr}8 & 0 \\ 11 & 0\end{array}$

Means for Oneway Anova

Level Number Mean Std Error Lower 95\% Upper 95\%

$\begin{array}{llllll}\text { KT7-1-1 } & 3 & 0.005857 & 0 & 0.00586 & 0.00586\end{array}$

$\begin{array}{llllll}K T 7-1-1 & 3 & 0.005857 & 0 & 0.00586 & 0.00586 \\ \text { KT7-1-2 } & 3 & 0.005857 & 0 & 0.00586 & 0.00586 \\ \text { KT7-2-1 } & 3 & 0.005857 & 0 & 0.00586 & 0.00586\end{array}$

$\begin{array}{llllll}K 17-1-2 & 3 & 0.005857 & 0 & 0.00586 & 0.00586 \\ K 17-2-1 & 3 & 0.005857 & 0 & 0.00586 & 0.00586\end{array}$

Std Error uses a pooled estimate of error variance 
Exhibit A-3. Statistical Evaluation of the ICP Calibration Effects from the KT07 Batch 1 Results by Oxide. (continued)

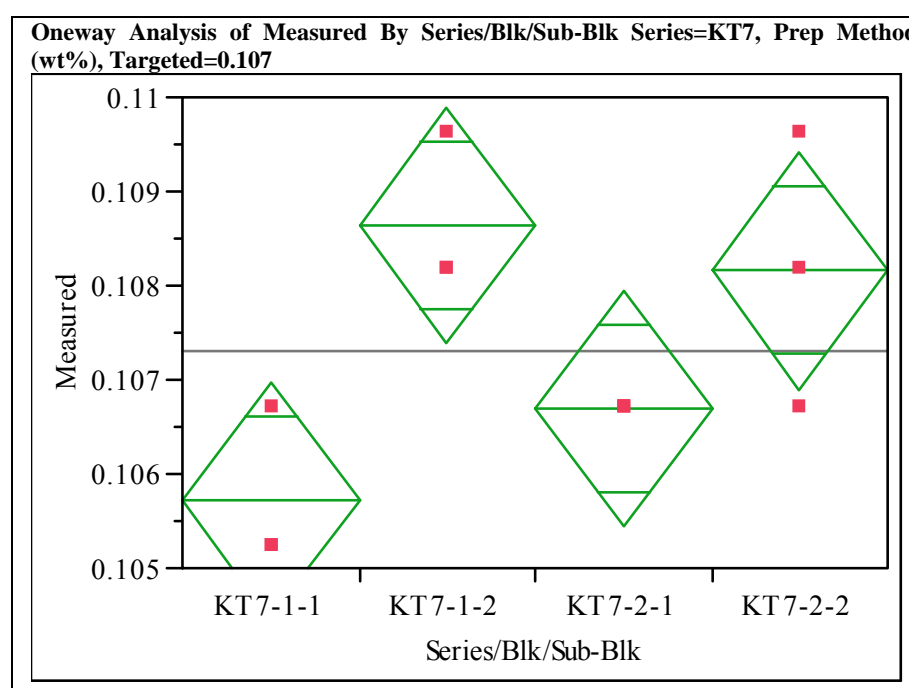

Oneway Anova

Summary of Fit

$\begin{array}{lr}\text { Rsquare } & 0.694656 \\ \text { Adj Rsquare } & 0.580153 \\ \text { Root Mean Square Error } & 0.000943 \\ \text { Mean of Response } & 0.107306 \\ \text { Observations (or Sum Wgts) } & 12\end{array}$

Observations (or Sum

Analysis of Variance
Source DF Sum of Squares Mean Square F Ratio Prob $>$ F

$\begin{array}{lrrrrr}\text { Source } & \text { DF } & \text { Sum of Squares } & \text { Mean Square } & \text { F Ratio } & \text { Prob }>\text { F } \\ \text { Series/Blk/Sub-Blk } & 3 & 0.00001620 & 0.0000054 & 6.0667 & 0.0186\end{array}$

$\begin{array}{lrrr}\text { Error } & 8 & 0.00000712 & 8.9011 \mathrm{e}-7 \\ \text { C. Total } & 11 & 0.00002332 & \end{array}$

0.00002332

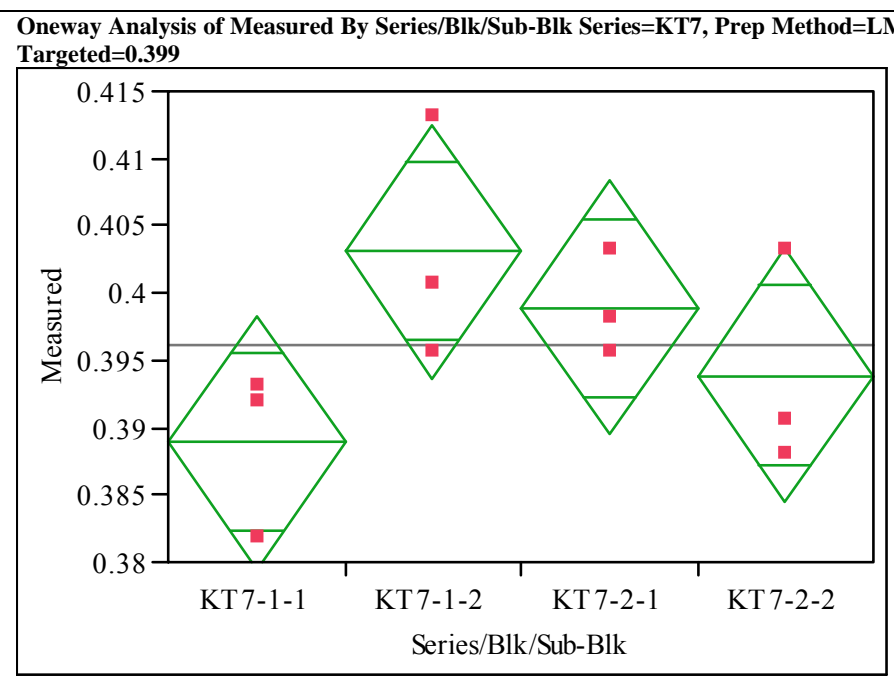

Oneway Anova

Summary of Fit

Rsquare

$\begin{array}{ll}0.460722 \\ \text { Adj Rsquare } & 0.258493\end{array}$

Root Mean Square Error $\quad 0.007054$

0.396195
12

Analysis of Variance

Source DF Sum of Squares Mean Square F Ratio Prob $>$ F

$\begin{array}{llllll}\text { Series/Blk/Sub-Blk } & 3 & 0.00034004 & 0.000113 & 2.2782 & 0.1565\end{array}$

$\begin{array}{lrr}\text { Error } & 8 & 0.00039802 \\ \text { C. Total } & 11 & 0.00073806\end{array}$

Means for Oneway Anova

Level Number Mean Std Error Lower 95\% Upper 95\%

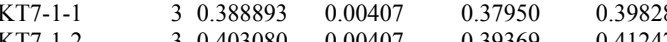

$\begin{array}{llllll}\text { KT7-1-1 } & 3 & 0.388893 & 0.00407 & 0.37950 & 0.39828 \\ \text { KT7-1-2 } & 3 & 0.403080 & 0.00407 & 0.39369 & 0.41247 \\ \text { KT7-2-2 } & 3 & 0.398907 & 0.00407 & 0.38952 & 0.40830\end{array}$

$\begin{array}{llllll}K 17-1-2 & 3 & 0.403080 & 0.00407 & 0.39369 & 0.41247 \\ \text { KT7-2-1 } & 3 & 0.398907 & 0.00407 & 0.38952 & 0.40830\end{array}$

Std Error uses a pooled estimate of error variance 
Exhibit A-3. Statistical Evaluation of the ICP Calibration Effects from the KT07 Batch 1 Results by Oxide. (continued)

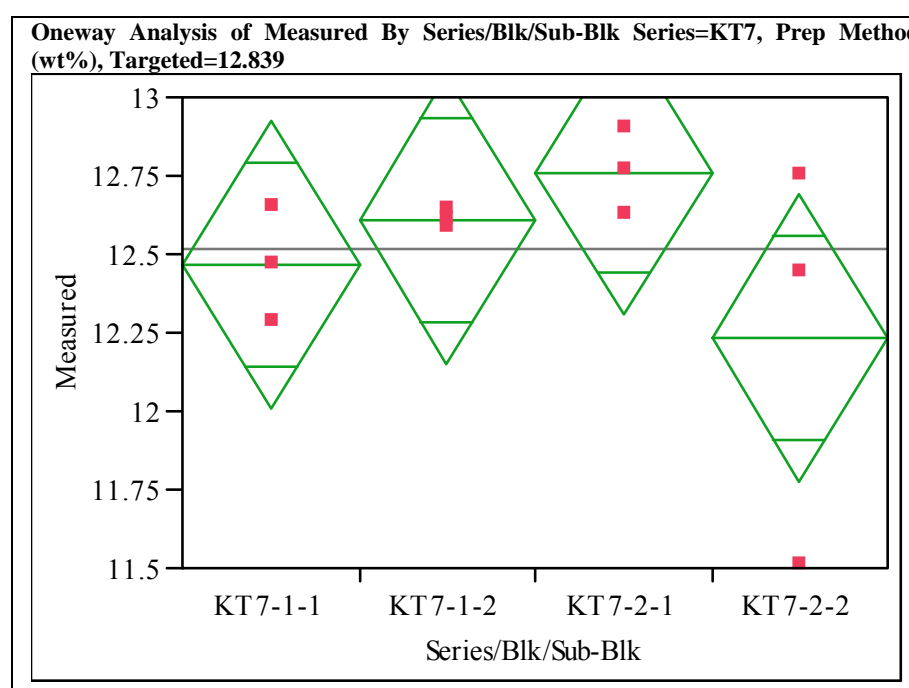

\section{Oneway Anova}

Summary of Fit

$\begin{array}{lr}\text { Rsquare } & 0.325341 \\ \text { Adj Rsquare } & 0.072344 \\ \text { Root Mean Square Error } & 0.34355 \\ \text { Mean of Response } & 12.51821 \\ \text { Obe }\end{array}$

$\begin{array}{lr}\text { Root Mean Square Error } & 0.34355 \\ \text { Mean of Response } & 12.5182\end{array}$

Observations (or Sum Wgts) $\quad 12$

Analysis of Variance

Source DF Sum of Squares Mean Square F Ratio Prob > F

$\begin{array}{lrrrrr}\text { Series/Blk/Sub-Blk } & 3 & 0.4553274 & 0.151776 & 1.2859 & 0.3436\end{array}$

Error

$\begin{array}{lll}0.151776 & 1.2859 & 0.3436 \\ 0.118026 & & \end{array}$

C. Total

$\begin{array}{rr}8 & 0.9442112 \\ 11 & 13995386\end{array}$

Means for Oneway Anova

Level Number Mean Std Error Lower 95\% Upper 95\%

$\begin{array}{llllll}\text { KT7-1-1 } & 3 & 12.4670 & 0.19835 & 12.010 & 12.924 \\ \text { KT7-1-2 } & 3 & 12.6100 & 0.19835 & 12.153 & 13.067\end{array}$

$\begin{array}{llllll}\text { KT7-1-2 } & 3 & 12.6100 & 0.19835 & 12.153 & 13.067 \\ \text { KT7-2-1 } & 3 & 12.7625 & 0.19835 & 12.305 & 13.220\end{array}$

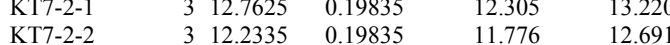

Std Error uses a pooled estimate of error variance

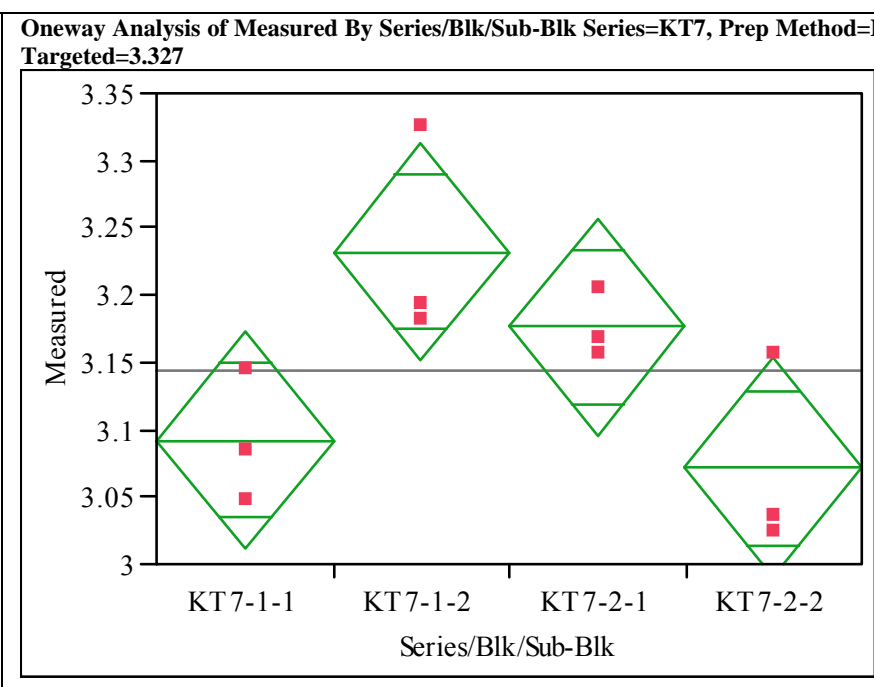

Oneway Anova

\section{Summary of Fit}

Rsquare

0.629708

Root Mean Square Error $\quad 0.49849$

Mean of Response 3.143002

Observations (or Sum Wgts) $\quad 12$

Analysis of Variance

Source DF Sum of Squares Mean Square F Ratio Prob $>$ F

$\begin{array}{lrrrrr}\text { Series/Blk/Sub-Blk } & 3 & 0.05033973 & 0.016780 & 4.5349 & 0.0388\end{array}$

\begin{tabular}{lll} 
Error & 8 & 0.02960165 \\
\hline
\end{tabular}

0.003700

C. Total

0.07994138

Means for Oneway Anova

Level Number Mean Std Error Lower 95\% Upper 95\%

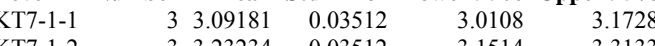

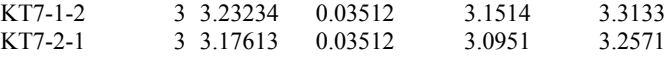

$\begin{array}{llllll}\text { KT7-2-1 } & 3 & 3.17613 & 0.03512 & 3.0951 & 3.2571 \\ \text { KT7-2-2 } & & 3.07173 & 0.03512 & 2.9907 & 3.1527\end{array}$

Std Error uses a pooled estimate of error variance 
Exhibit A-3. Statistical Evaluation of the ICP Calibration Effects from the KT07 Batch 1 Results by Oxide. (continued)

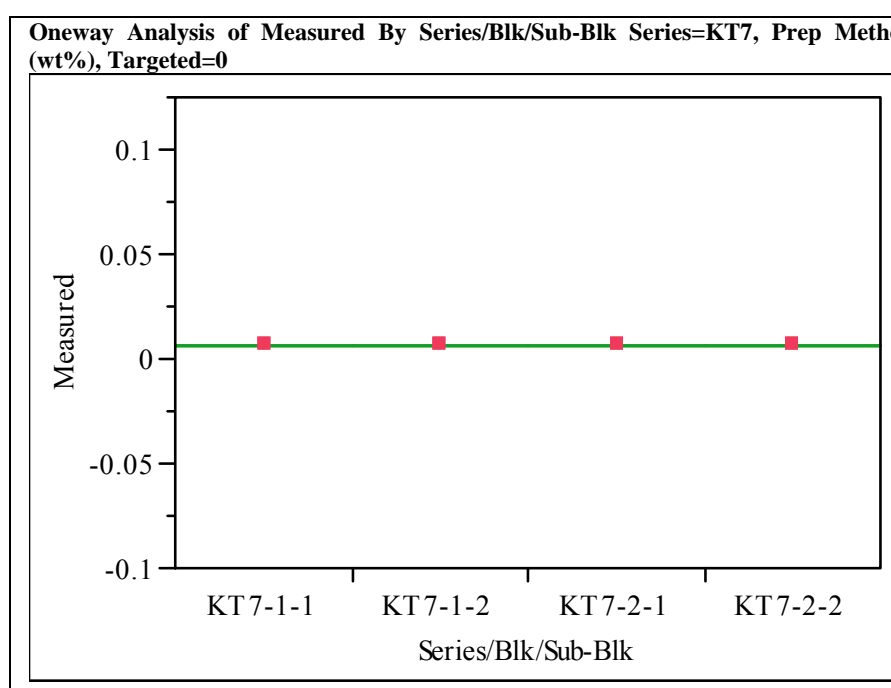

Oneway Anova

Summary of Fit

Rsquare

Adj Rsquare

Root Mean Square Error $\quad 0$

$\begin{array}{lr}\text { Mean of Response } & 0.005864 \\ \text { Observations (or Sum Wgts) } & 12\end{array}$

Analysis of Variance

Source DF Sum of Squares Mean Square F Ratio Prob $>$ F

Series/Blk/Sub-Blk $\quad 3 \quad r$ S

$\begin{array}{lr}\text { Error } & 8 \\ \text { C. Total } & 11\end{array}$

1

Means for Oneway Anova

Level Number Mean Std Error Lower 95\% Upper 95\%

$\begin{array}{llllrr}\text { KT7-1-1 } & 3 & 0.005864 & 0 & 0.00586 & 0.00586 \\ \text { KT7-1-2 } & 3 & 0.005864 & 0 & 0.0586 & 0.005886\end{array}$

$\begin{array}{llllll}\text { KT7-1-2 } & 3 & 0.005864 & 0 & 0.00586 & 0.00586 \\ \text { KT7-2-1 } & 3 & 0.005864 & 0 & 0.00586 & 0.00586\end{array}$

$\begin{array}{llllll}\text { KT7-2-1 } & 3 & 0.005864 & 0 & 0.00586 & 0.00586 \\ \text { KT7-2-2 } & 3 & 0.005864 & 0 & 0.00586 & 0.00586\end{array}$

Std Error uses a pooled estimate of error variance

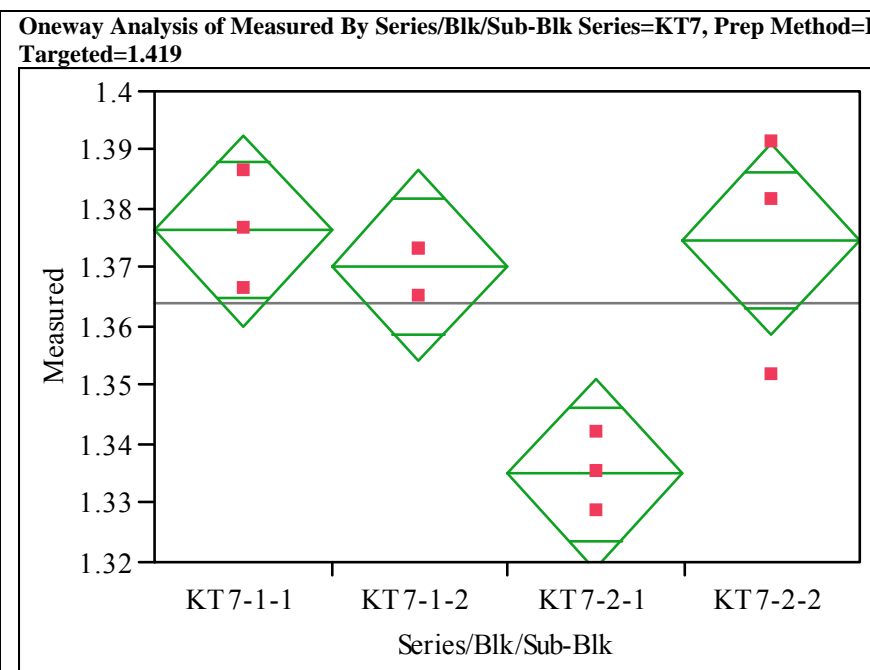

Oneway Anova

Summary of Fit

Rsquare

$\begin{array}{ll}0.744123 \\ \text { Adj Rsquare } & 0.648169\end{array}$

Root Mean Square Error $\quad 0.012195$

Mean of Response

0.012195
1.36409

Observations (or Sum Wgts)

Analysis of Variance

Source DF Sum of Squares Mean Square F Ratio Prob $>$ F

$\begin{array}{llrrrr}\text { Series/Blk/Sub-Blk } & 3 & 0.00346014 & 0.001153 & 7.7550 & 0.0094\end{array}$

$\begin{array}{lrr}\text { Error } & 8 & 0.00118982\end{array}$

0.00149

Means for Oneway Anova

Level Number Mean Std Error Lower 95\% Upper 95\%

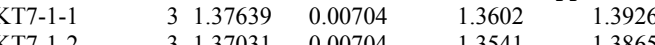

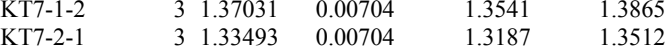

$\begin{array}{llllll}\text { KT7-2-1 } & 3 & 1.33493 & 0.00704 & 1.3187 & 1.3512 \\ \text { KT7-2-2 } & 3 & 1.37473 & 0.00704 & 1.3585 & 1.3910\end{array}$

Std Error uses a pooled estimate of error variance 
Exhibit A-3. Statistical Evaluation of the ICP Calibration Effects from the KT07 Batch 1 Results by Oxide. (continued)

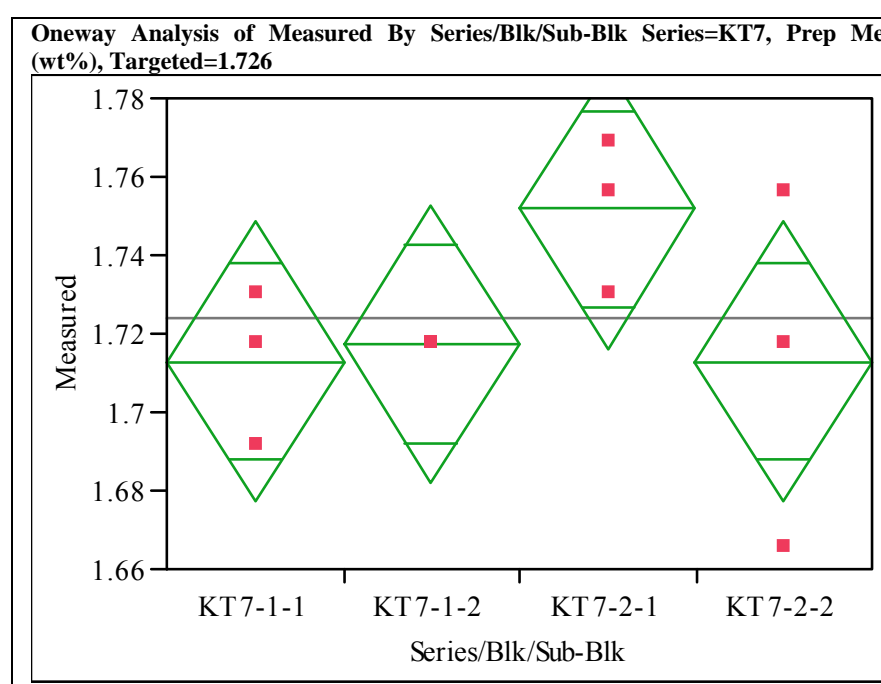

\section{Oneway Anova}

Summary of Fit

Adj Rsquare $\quad 0.35849$

Root Mean Square Error $\quad 0.117925$

Mean of Response 1.723752

Observations (or Sum Wgts) 12

Analysis of Variance

Source DF Sum of Squares Mean Square F Ratio Prob $>$ F

$\begin{array}{lrrrrr}\text { Series/Blk/Sub-Blk } & 3 & 0.00316768 & 0.001056 & 1.4902 & 0.2892\end{array}$

Error

$\begin{array}{lll}0.001056 & 1.4902 & 0.2892 \\ 0.000709 & & \end{array}$

C. Total

0.00883615

Means for Oneway Anova

Level Number Mean Std Error Lower 95\% Upper 95\%

$\begin{array}{llllll}\text { KT7-1-1 } & 3 & 1.71299 & 0.01537 & 1.6776 & 1.7484 \\ \text { KT7-1-2 } & 3 & 1.71730 & 0.01537 & 1.6819 & 1.7527\end{array}$

$\begin{array}{llllll}\text { KT7-1-1 } & 3 & 1.71299 & 0.01537 & 1.6776 & 1.7484 \\ \text { KT7-1-2 } & 3 & 1.71730 & 0.01537 & 1.6819 & 1.7527 \\ \text { KT7-2-1 } & 3 & 1.75173 & 0.01537 & 1.7163 & 1.7872\end{array}$

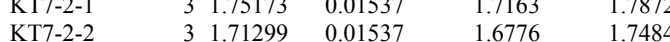

Std Error uses a pooled estimate of error variance

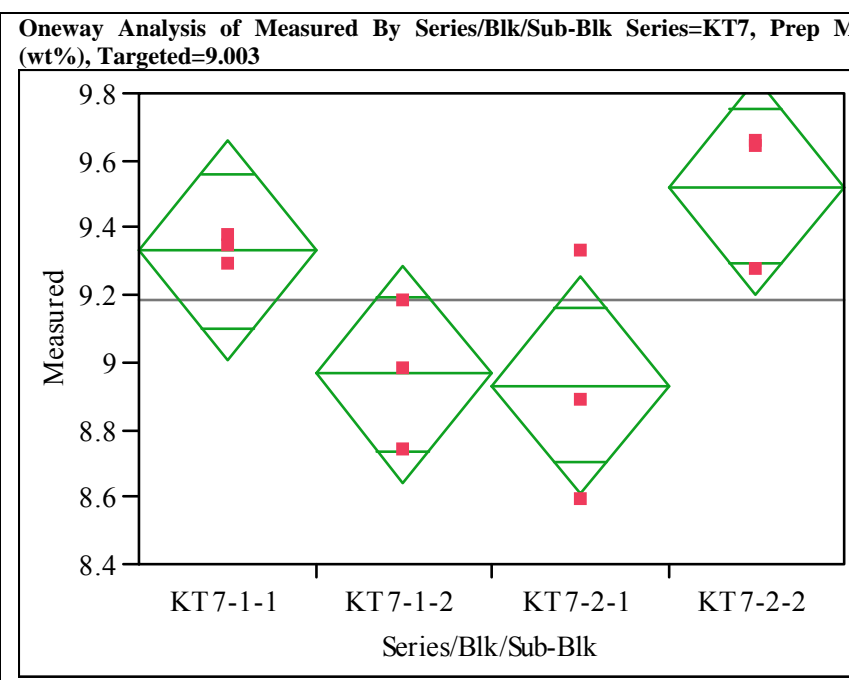

\section{Oneway Anova}

Summary of Fit

Rsquare

$\begin{array}{ll} & 0.610766 \\ \text { Adj Rsquare } & 0.464803\end{array}$

Root Mean Square Error $\quad 0.243108$

Mean of Response

0.243108
9.187743

Observations (or Sum Wgts)

Analysis of Variance

Source DF Sum of Squares Mean Square F Ratio Prob $>$ F

$\begin{array}{lrrrrr}\text { Series/Blk/Sub-Blk } & 3 & 0.7419084 & 0.247303 & 4.1844 & 0.0468\end{array}$

Error

C. Total

$\begin{array}{rr}8 & 0.4728105 \\ 11 & 1.2147189\end{array}$

Means for Oneway Anova

Level Number Mean Std Error Lower 95\% Upper 95\%

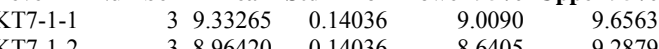

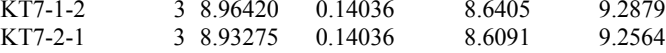

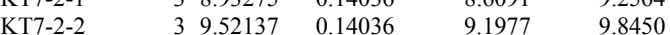

Std Error uses a pooled estimate of error variance 
Exhibit A-3. Statistical Evaluation of the ICP Calibration Effects from the KT07 Batch 1 Results by Oxide. (continued)

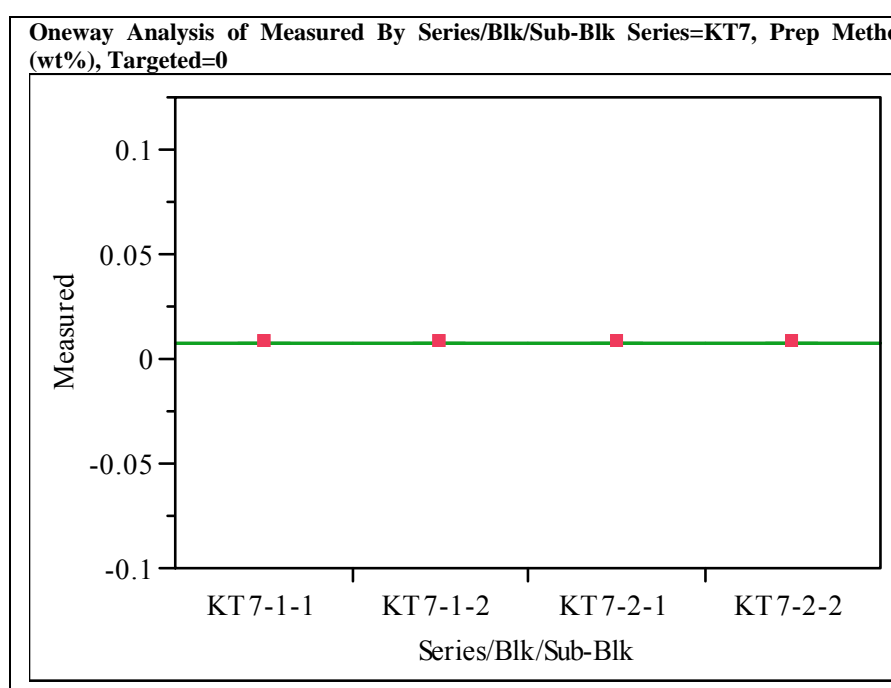

Oneway Anova

Summary of Fit

Rsquare

Adj Rsquare $\quad 0$

Root Mean Square Error $\quad 1.06 \mathrm{e}-18$

$\quad 0.007153$

Observations (or Sum Wgts) $\quad 12$

Analysis of Variance

Source DF Sum of Squares Mean Square F Ratio Prob $>$ F

$\begin{array}{lrrrrr}\text { Series/Blk/Sub-Blk } & 3 & 0 & 0 & 0.0000 & 1.0000\end{array}$

Error

$\begin{array}{rrr}8 & 9.0278 \mathrm{e}-36 & 1.128 \mathrm{e}-36\end{array}$

C. Total

9.0278e-36

Means for Oneway Anova

Level Number Mean Std Error Lower 95\% Upper 95\%

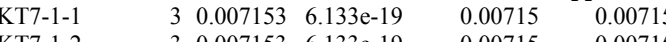

$\begin{array}{llllll}\text { KT7-1-2 } & 3 & 0.007153 & 6.133 \mathrm{e}-19 & 0.00715 & 0.00715 \\ \text { KT7 } 2-1 & 3 & 0.007153 & 6.133 \mathrm{e}-19 & 0.00715 & 0.00715\end{array}$

$\begin{array}{llllll}\text { KT7-2-1 } & 3 & 0.007153 & 6.133 \mathrm{e}-19 & 0.00715 & 0.00715 \\ \text { KT7-2-2 } & 3 & 0.007153 & 6.133 \mathrm{e}-19 & 0.00715 & 0.00715\end{array}$

Std Error uses a pooled estimate of error variance

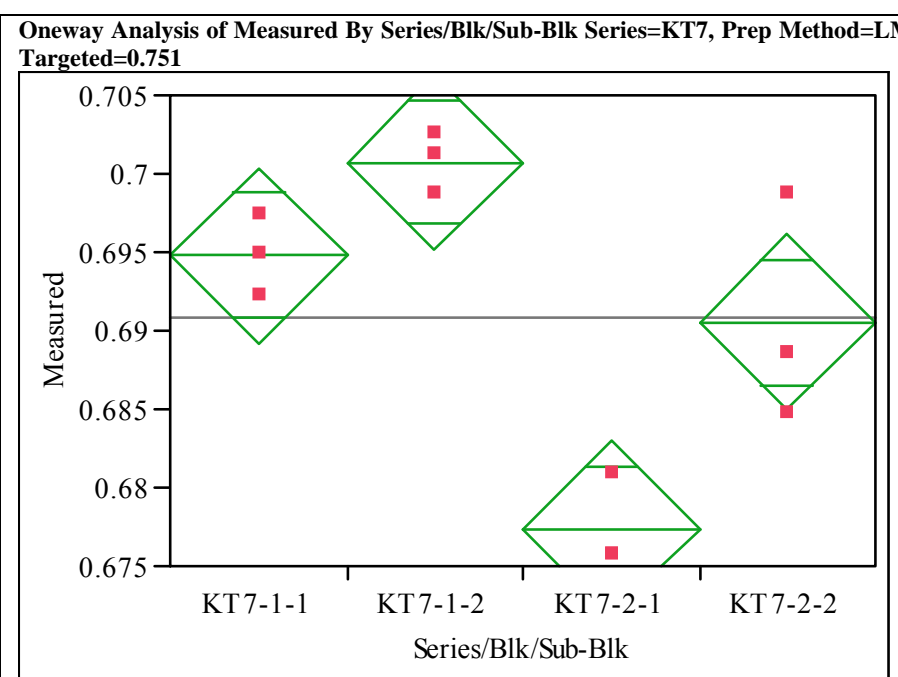

Oneway Anova

Summary of Fit

Rsquare

Adj Rsquare

Root Mean Square Error

Mean of Response

0.860961

0.808822

0.090861

Observations (or Sum Wgts) $\quad 12$

Analysis of Variance

Source DF Sum of Squares Mean Square F Ratio Prob $>$ F

$\begin{array}{lrrrrr}\text { Series/Blk/Sub-Blk } & 3 & 0.00088236 & 0.000294 & 16.5126 & 0.0009\end{array}$

$\begin{array}{lrr}\text { Error } & 8 & 0.00014249\end{array}$

0.00018

Means for Oneway Anova

Level Number Mean Std Error Lower 95\% Upper 95\%

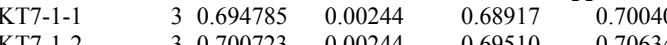

$\begin{array}{llllll}\mathrm{K} T 7-1-1 & 3 & 0.694785 & 0.00244 & 0.68917 & 0.70040 \\ \mathrm{KT} 7-1-2 & 3 & 0.700723 & 0.00244 & 0.69510 & 0.70634 \\ \text { KT7-2-1 } & 3 & 0.677394 & 0.00244 & 0.67178 & 0.68301\end{array}$

$\begin{array}{llllll}\text { KT7-1-2 } & 3 & 0.700723 & 0.00244 & 0.69510 & 0.70634 \\ \text { KT7-2-1 } & 3 & 0.677594 & 0.00244 & 0.67178 & 0.68301\end{array}$

Std Error uses a pooled estimate of error variance 
Exhibit A-3. Statistical Evaluation of the ICP Calibration Effects from the KT07 Batch 1 Results by Oxide. (continued)

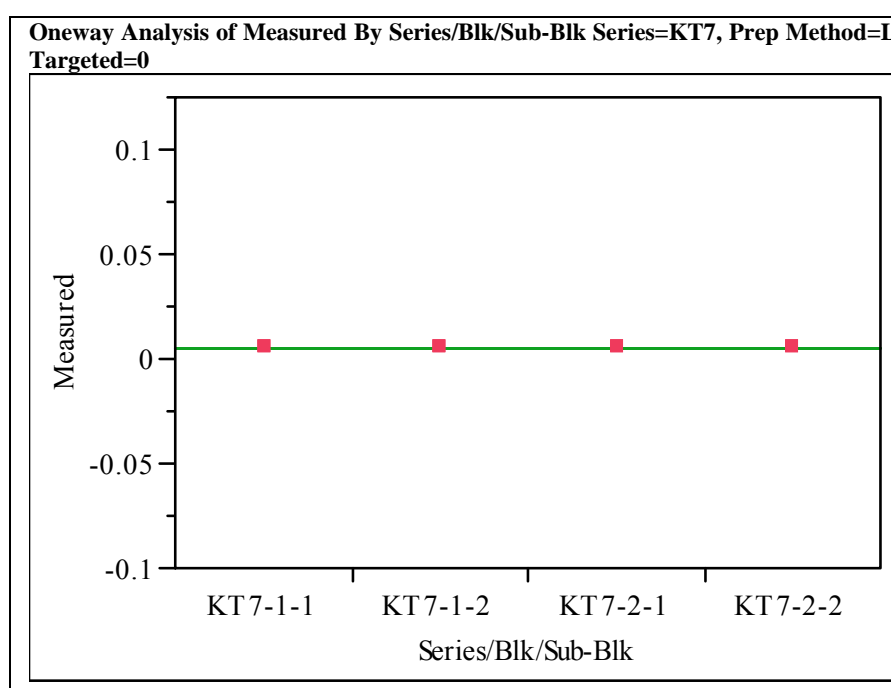

Oneway Anova

Summary of Fit

Rsquare

Adj Rsquare $\quad 0$

Root Mean Square Error $\quad 1.06 \mathrm{e}-18$

Mean of Response $\quad 0.005386$

Observations (or Sum Wgts) $\quad 12$

Analysis of Variance

Source DF Sum of Squares Mean Square F Ratio Prob $>$ F

$\begin{array}{lrrrrr}\text { Series/Blk/Sub-Blk } & 3 & 0 & 0 & 0.0000 & 1.0000\end{array}$

$\begin{array}{lrrr}\text { Error } & 8 & 9.0278 \mathrm{e}-36 & 1.128 \mathrm{e}-36 \\ \text { C. Total } & 11 & 9.0278 \mathrm{e}-36 & \end{array}$

$9.0278 \mathrm{e}-36$

Means for Oneway Anova

Level Number Mean Std Error Lower 95\% Upper 95\%

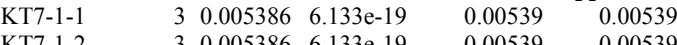

$\begin{array}{llllll}\text { KT7-1-2 } & 3 & 0.005386 & 6.133 \mathrm{e}-19 & 0.00539 & 0.00539 \\ \text { KT7 }-2-1 & 3 & 0.005386 & 6.133 \mathrm{e}-19 & 0.00539 & 0.00539\end{array}$

$\begin{array}{llllll}\text { KT7-2-1 } & 3 & 0.005386 & 6.133 \mathrm{e}-19 & 0.00539 & 0.00539 \\ \text { KT7-2-2 } & 3 & 0.005386 & 6.133 \mathrm{e}-19 & 0.00539 & 0.00539\end{array}$

Std Error uses a pooled estimate of error variance

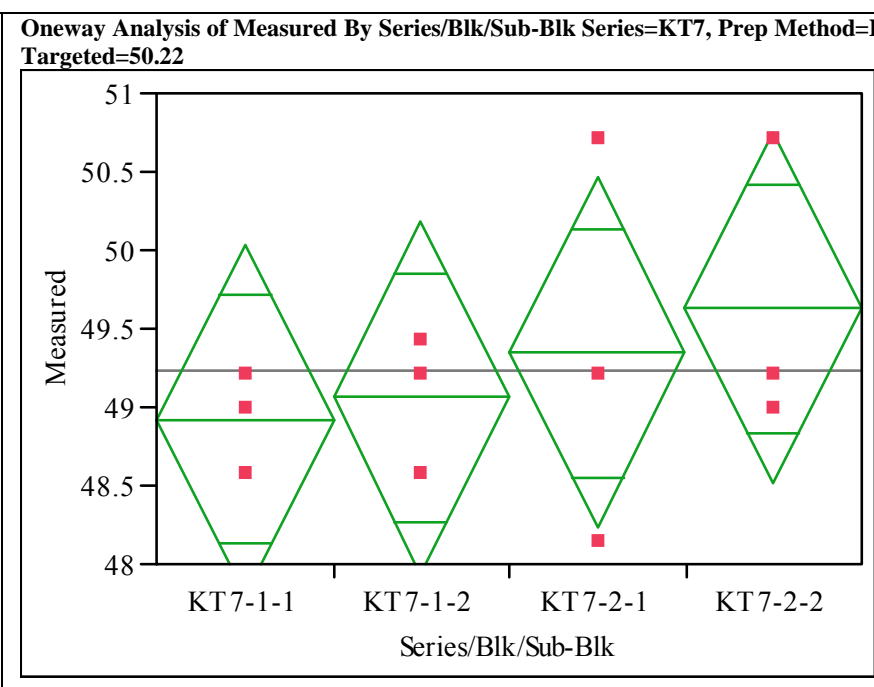

Oneway Anova

\section{Summary of Fit}

Rsquare

Root Mean Square Eror

Mean of Response

Observations (or Sum Wgts) 12

0.136891

$-0.18677$

49.23956

Analysis of Variance

Source DF Sum of Squares Mean Square F Ratio Prob $>$ F

$\begin{array}{llllll}\text { Series/Blk/Sub-Blk } & 3 & 0.9000655 & 0.300022 & 0.4229 & 0.7418\end{array}$

Error

6.5750551

Means for Oneway Anova

Level Number Mean Std Error Lower 95\% Upper 95\%

$\begin{array}{llllrr}\text { KT7-1-1 } & 3 & 48.9187 & 0.48627 & 47.797 & 50.040\end{array}$

$\begin{array}{llllll} & \\ \text { KT7-1-1-2 } & 3 & 48.0613 & 0.48627 & 47.940 & 50.183\end{array}$

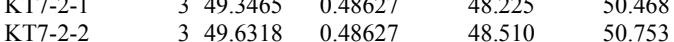

Std Error uses a pooled estimate of error variance 
Exhibit A-3. Statistical Evaluation of the ICP Calibration Effects from the KT07 Batch 1 Results by Oxide. (continued)

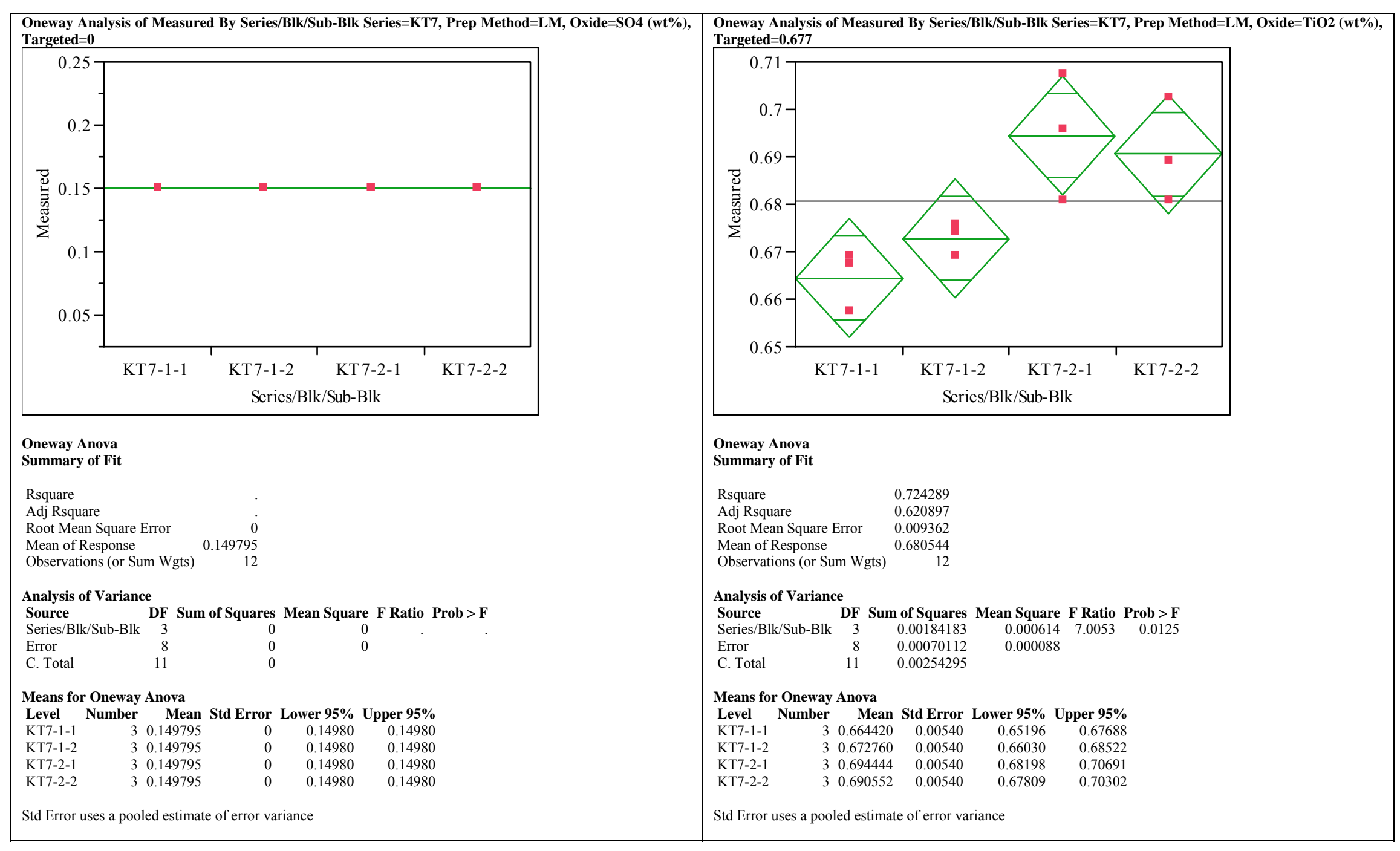


Exhibit A-3. Statistical Evaluation of the ICP Calibration Effects from the KT07 Batch 1 Results by Oxide. (continued)

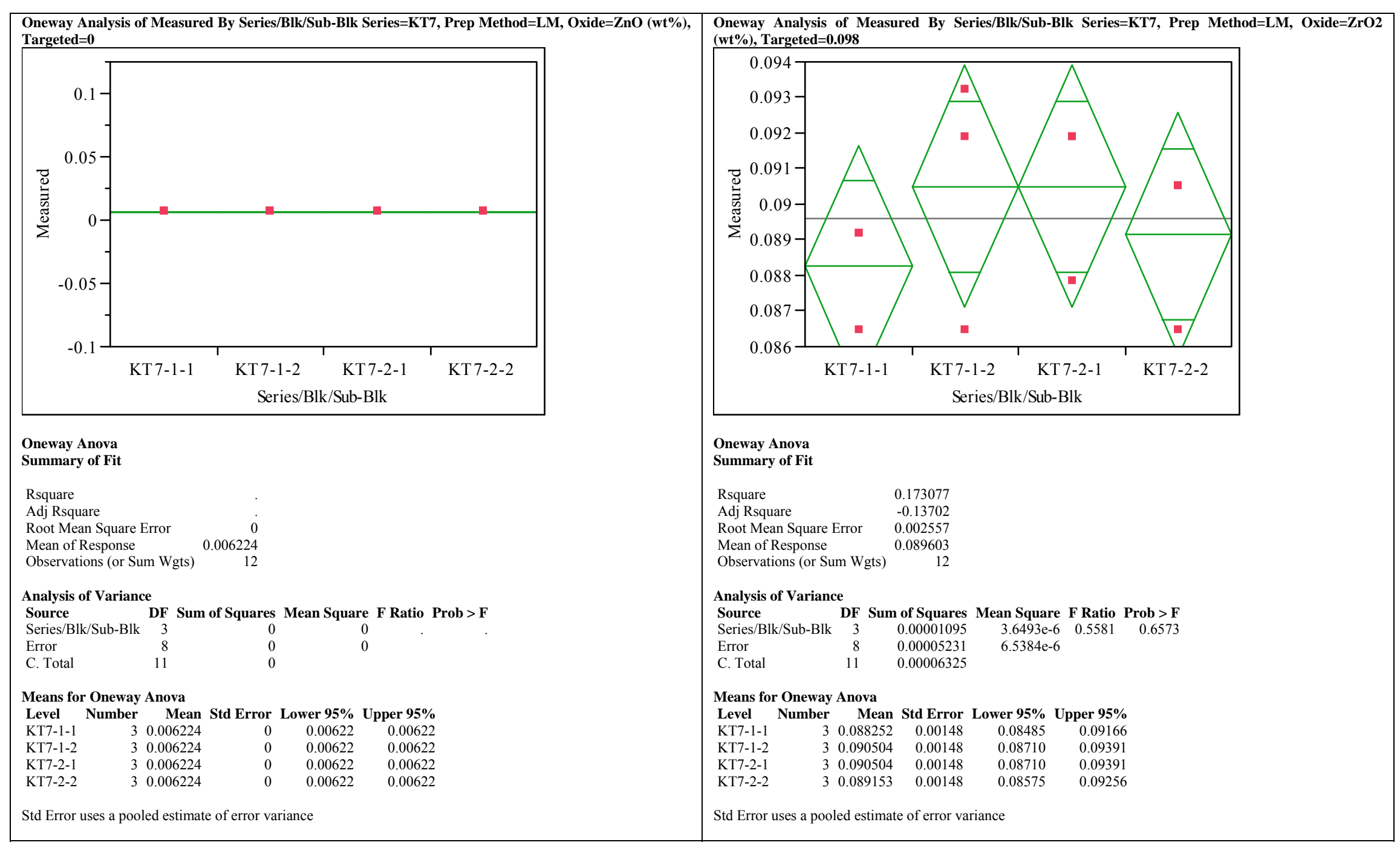


Exhibit A-3. Statistical Evaluation of the ICP Calibration Effects from the KT07 Batch 1 Results by Oxide. (continued)

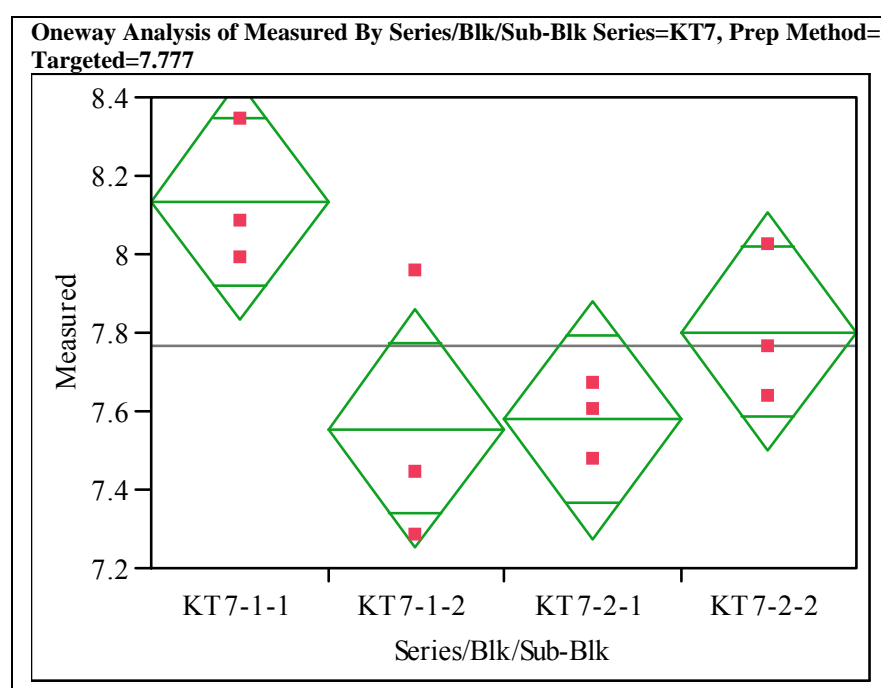

Oneway Anova

Summary of Fit

$\begin{array}{lr}\text { Rsquare } & 0.612286 \\ \text { Adj Rsquare } & 0.466894 \\ \text { Root Mean Square Error } & 0.227302 \\ \text { Mean of Response } & 7.768009 \\ \text { Observations (or Sum Wgts) } & 12\end{array}$

Observations (or Sum

Analysis of Variance

Source DF Sum of Squares Mean Square F Ratio Prob $>$ F $\begin{array}{lrrrrr} & & & & \\ \text { Series/Blk/Sub-Blk } & 3 & 0.6527366 & 0.217579 & 4.2113 & 0.0461 \\ \text { Error } & 8 & 0.4133279 & 0.051666 & & \end{array}$

Error $\quad 8-0.6527366$

C. Total

0.4133279
1.0660645

Means for Oneway Anova

Level Number Mean Std Error Lower 95\% Upper 95\%

$\begin{array}{llllll}\text { KT7-1-1 } & 3 & 8.13561 & 0.13123 & 7.8330 & 8.4382 \\ \text { KT7-1-2 } & & 3.55603 & 0.13123 & 7.2534 & 7.8587 \\ \text { KT7-2-1 } & & 3.57750 & 0.1323 & 7.2749 & 7.8801\end{array}$

$\begin{array}{llllll}\text { KT7-1-1 } & 3 & 8.13561 & 0.13123 & 7.8330 & 8.4382 \\ \text { KT7-1-2 } & 3 & 7.55603 & 0.13123 & 7.2534 & 7.858 \\ \text { KT7-2-1 } & 3 & 7.57750 & 0.13123 & 7.2749 & 7.8801\end{array}$

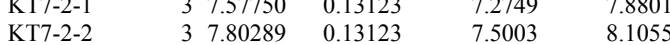

Std Error uses a pooled estimate of error variance

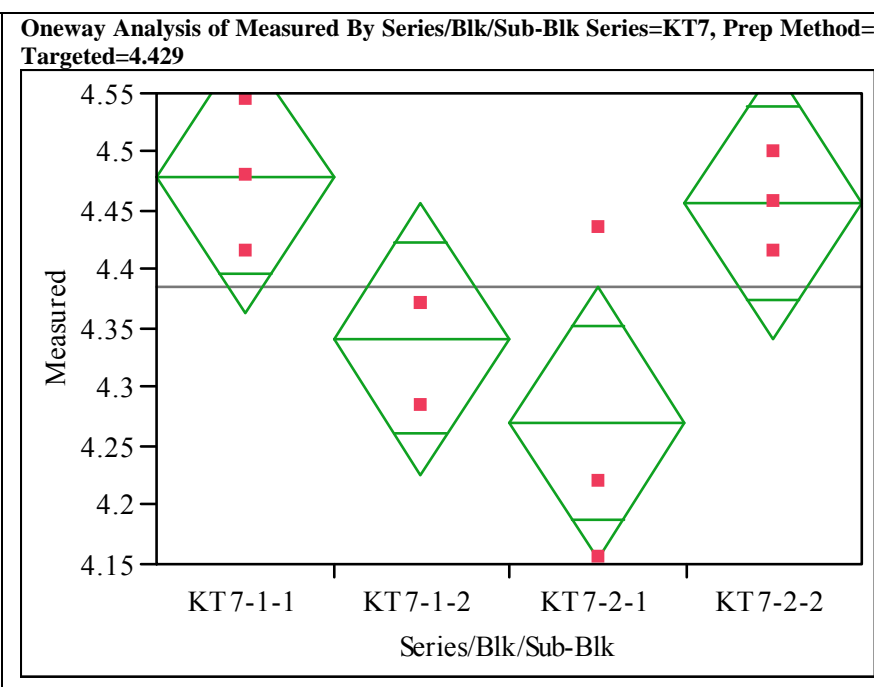

Oneway Anova

\section{Summary of Fit}

Rsquare

0.591041

Adj Rsquare $\quad 0.437681$

Root Mean Square Error -0.086563

Mean of Response 4.386534

Analysis of Variance

Source DF Sum of Squares Mean Square F Ratio Prob > F

$\begin{array}{lrrrrr}\text { Series/Blk/Sub-Blk } & 3 & 0.08663547 & 0.028878 & 3.8540 & 0.0564\end{array}$

$\begin{array}{lrrr}\text { Error } & 8 & 0.05994572 & 0.007493\end{array}$

0.14658119

Means for Oneway Anova

Level Number Mean Std Error Lower 95\% Upper 95\%

\begin{tabular}{llllrr} 
KT7-1-1 & 3 & 4.47803 & 0.04998 & 4.3628 & 4.5933 \\
\hline
\end{tabular}

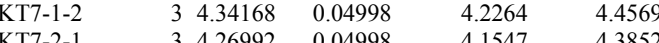

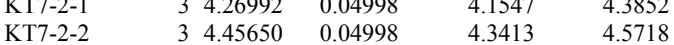

Std Error uses a pooled estimate of error variance 
Exhibit A-4. Plots of Measured versus Targeted Concentrations by Glass ID by Oxide. Oxide=Al2O3 (wt \%)

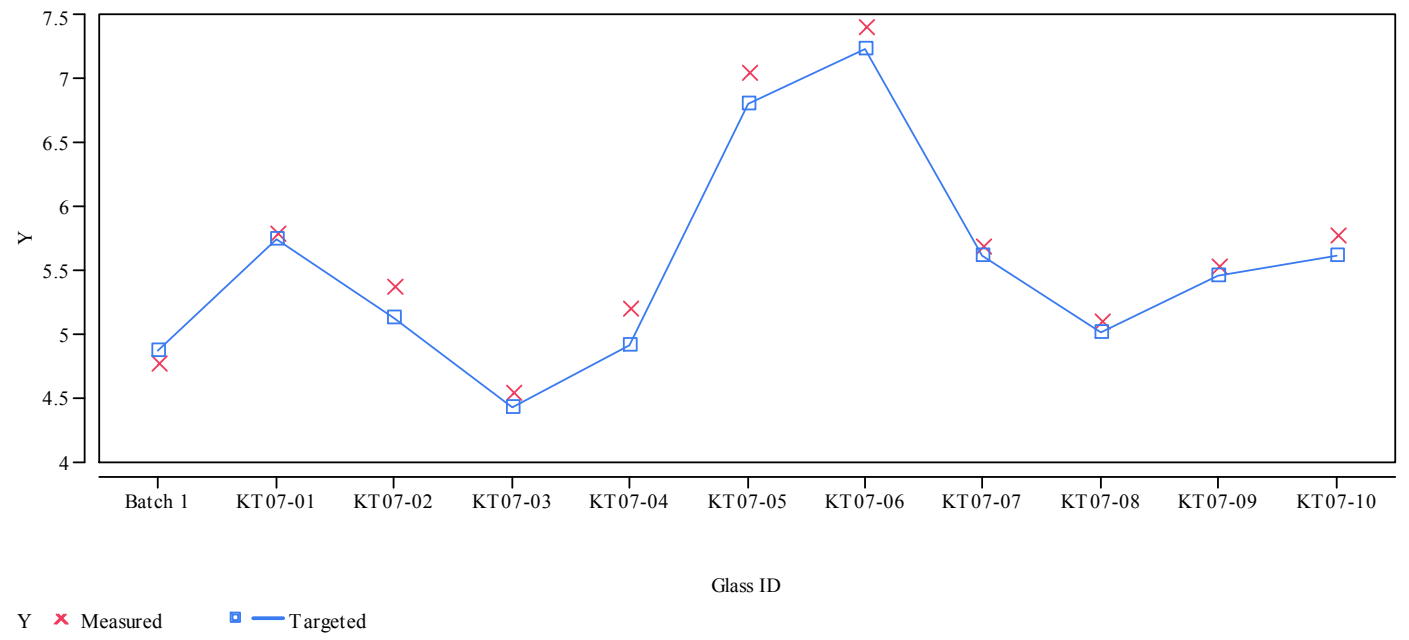

\section{Oxide=B2O3 (wt \%)}

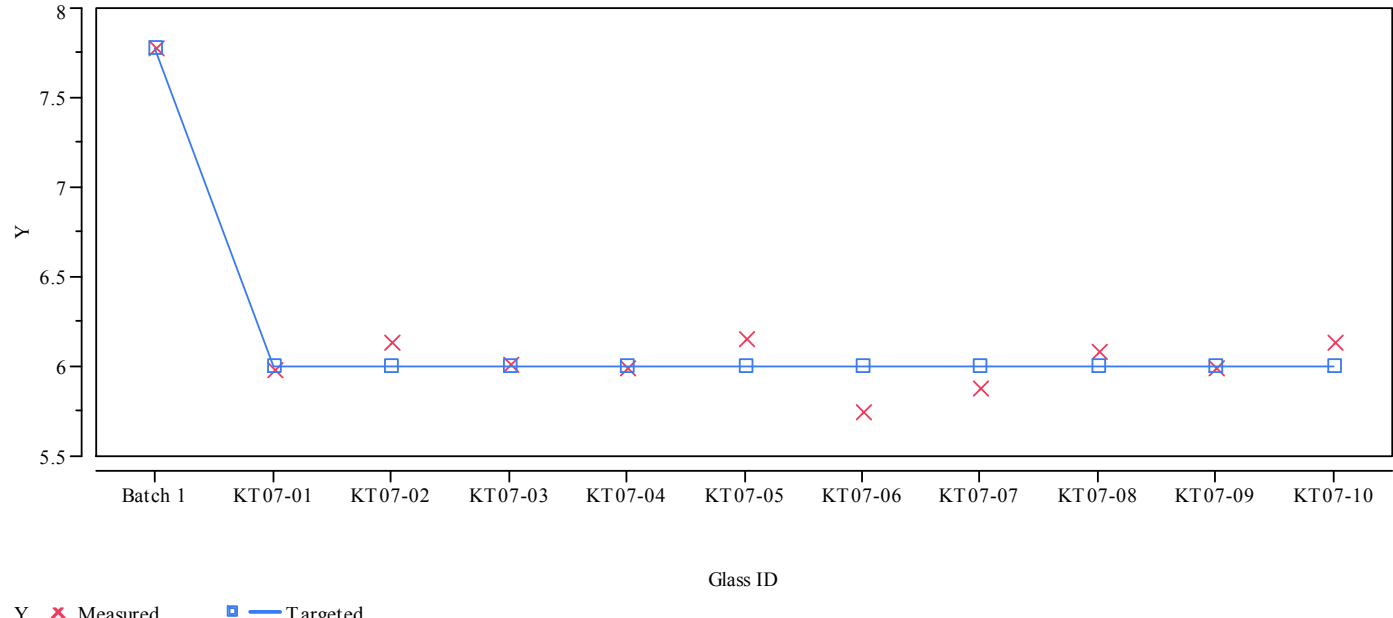

$$
\text { Y } \times \text { Measured } \square-T \text { argeted }
$$

Oxide $=\mathrm{BaO}(\mathrm{wt} \%)$

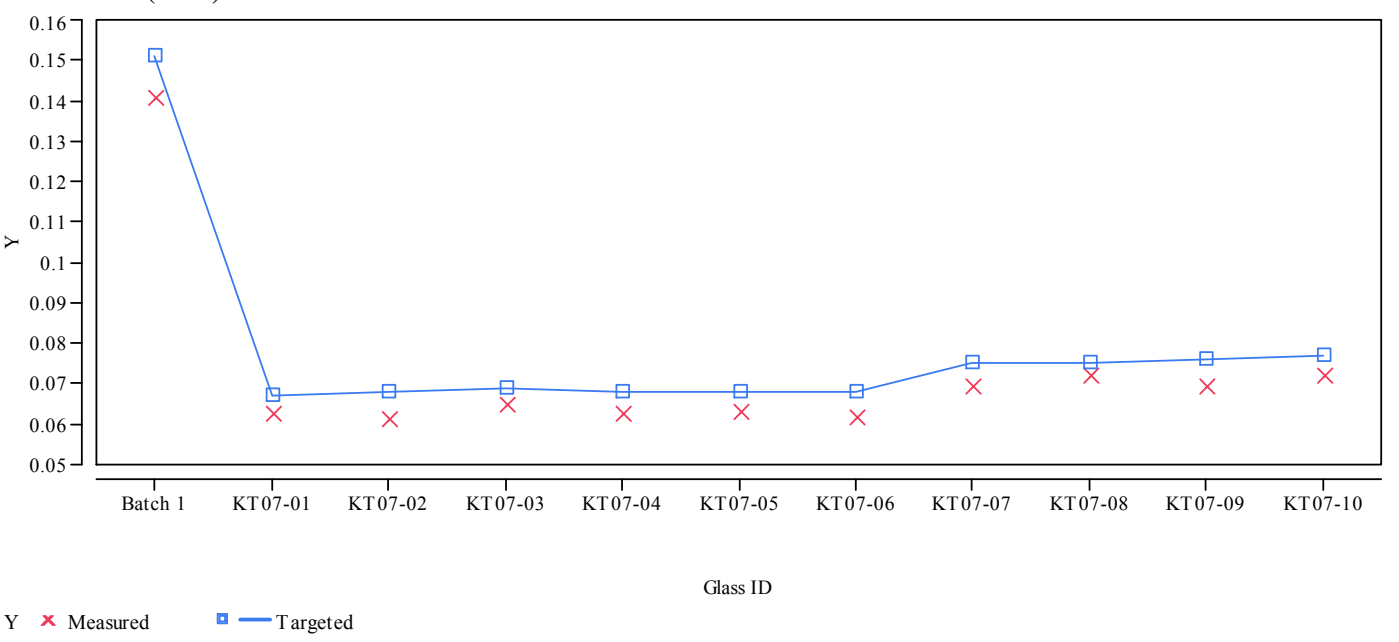


SRNL-STI-2010-00759

Revision 0

Exhibit A-4. Plots of Measured versus Targeted Concentrations by Glass ID by Oxide. (continued)

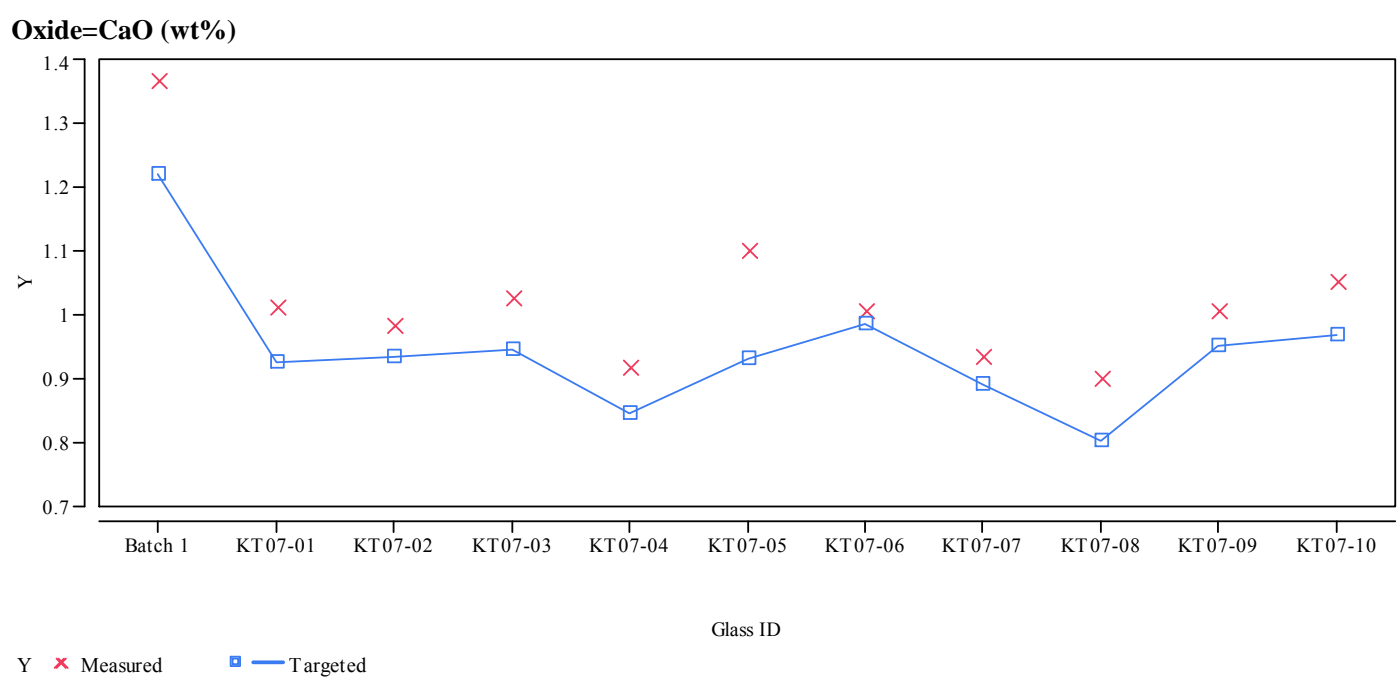

Oxide=Ce2O3 (wt\%)

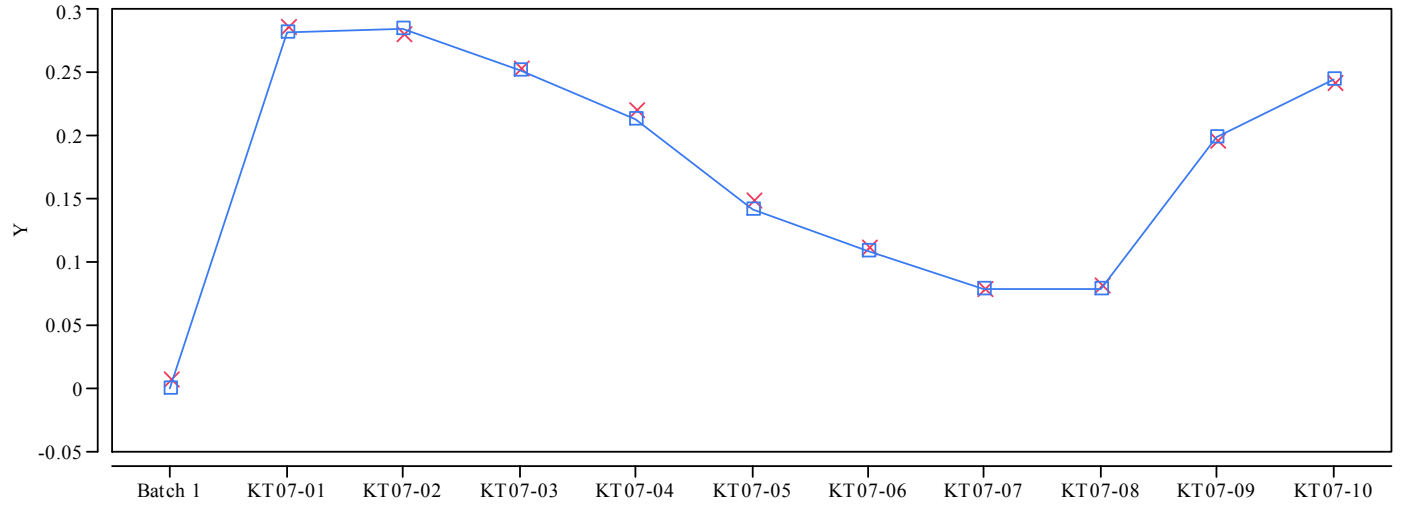

Y $\times$ Measured $\square-$ Targeted

Glass ID

Oxide=Cr2O3 (wt\%)

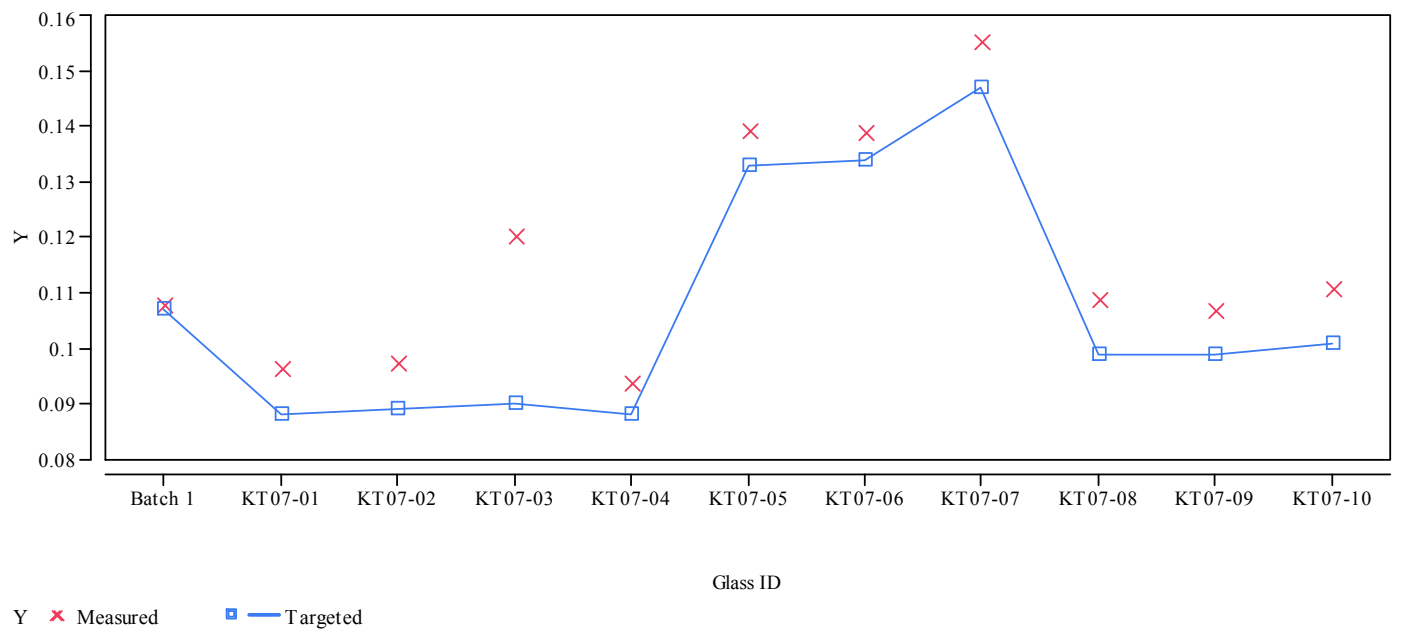


SRNL-STI-2010-00759

Revision 0

Exhibit A-4. Plots of Measured versus Targeted Concentrations by Glass ID by Oxide. (continued)

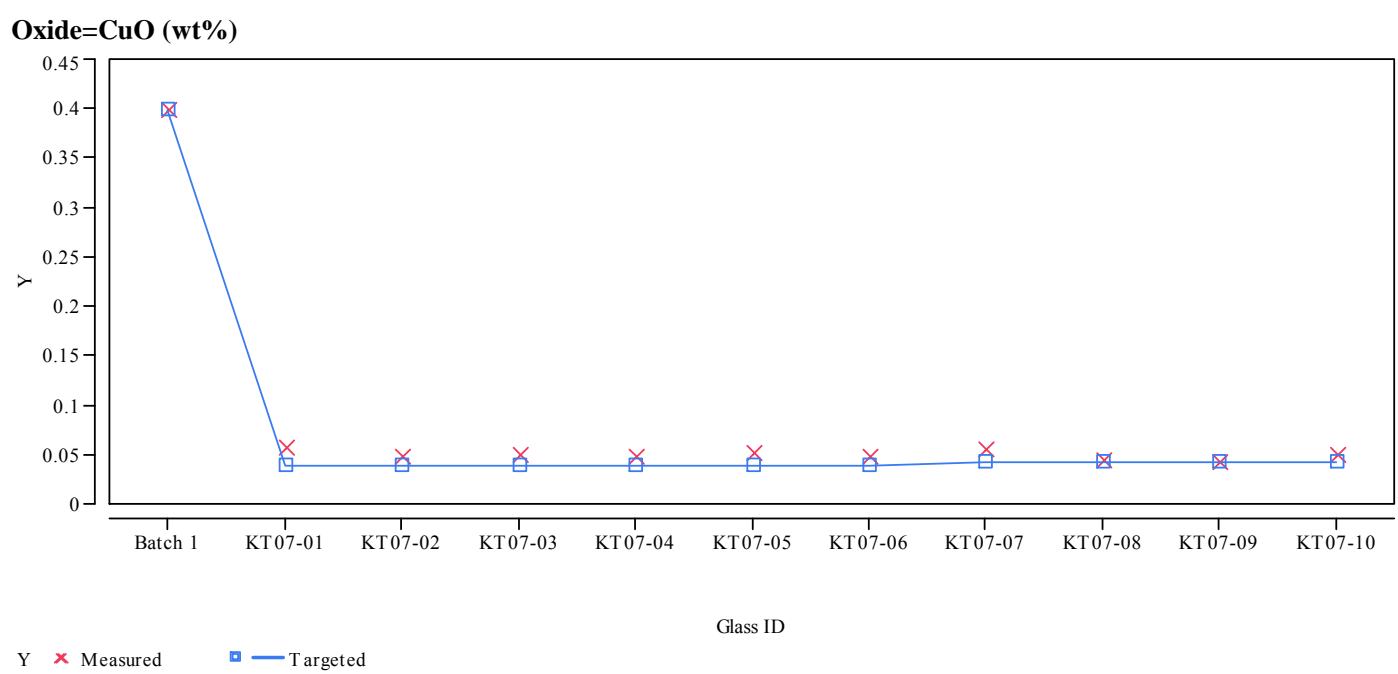

Oxide=Fe2O3 (wt \%)

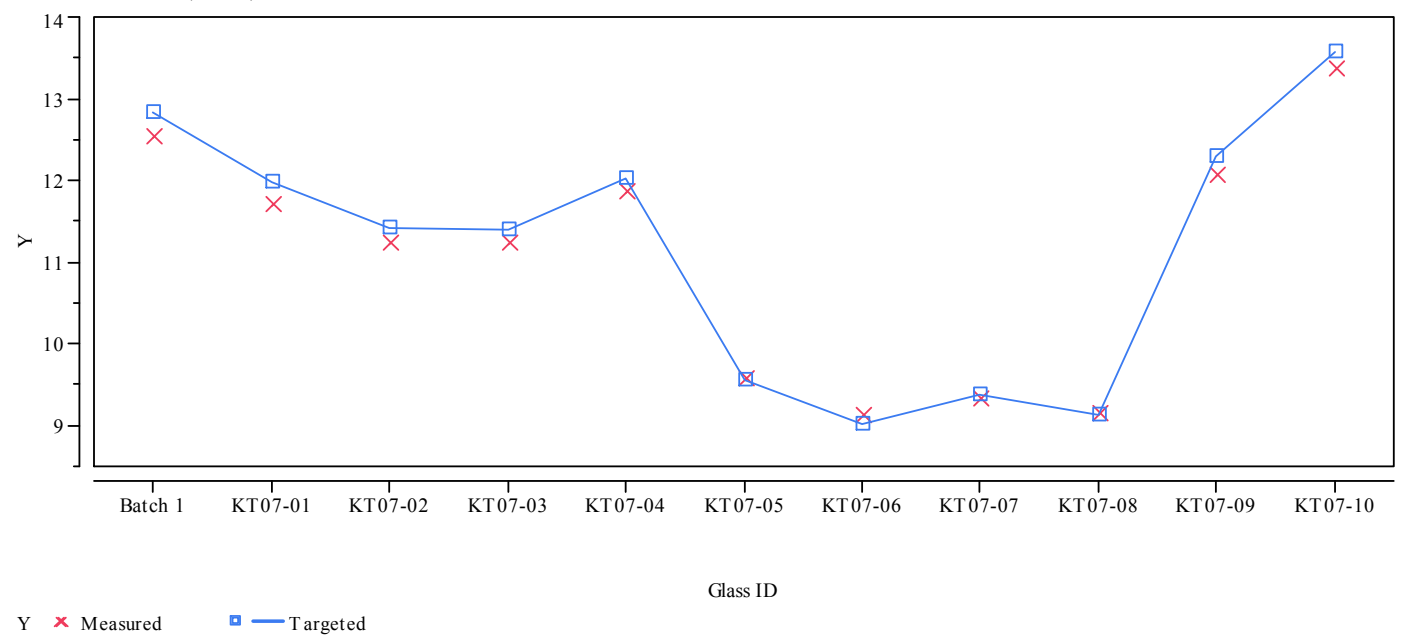

Oxide=K2O (wt \%)

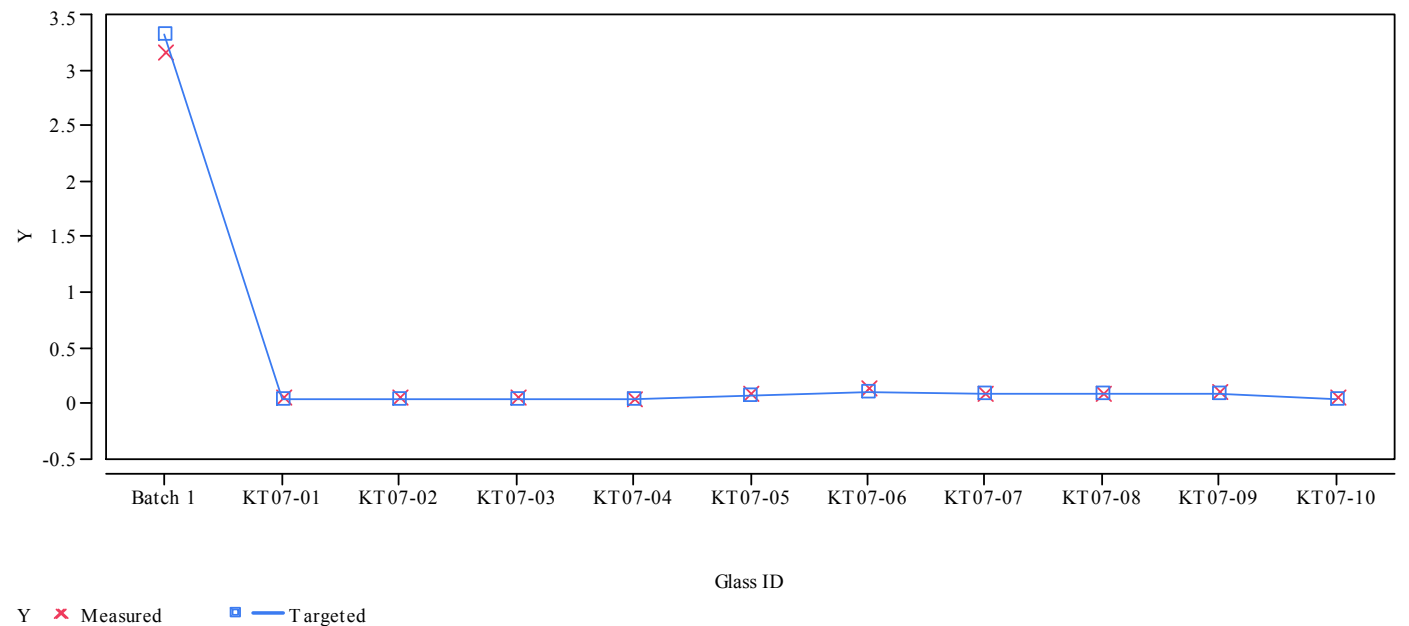


Exhibit A-4. Plots of Measured versus Targeted Concentrations by Glass ID by Oxide. (continued)

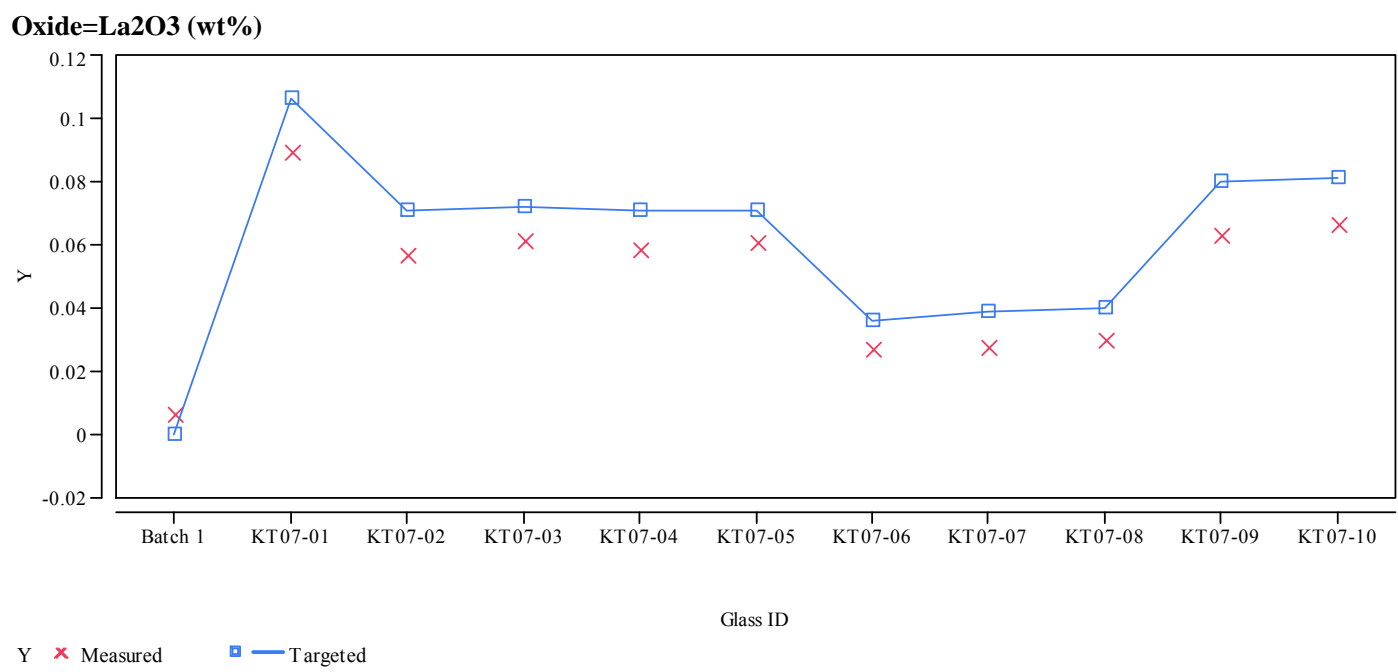

\section{Oxide $=\mathrm{Li2O}(\mathrm{wt} \%)$}

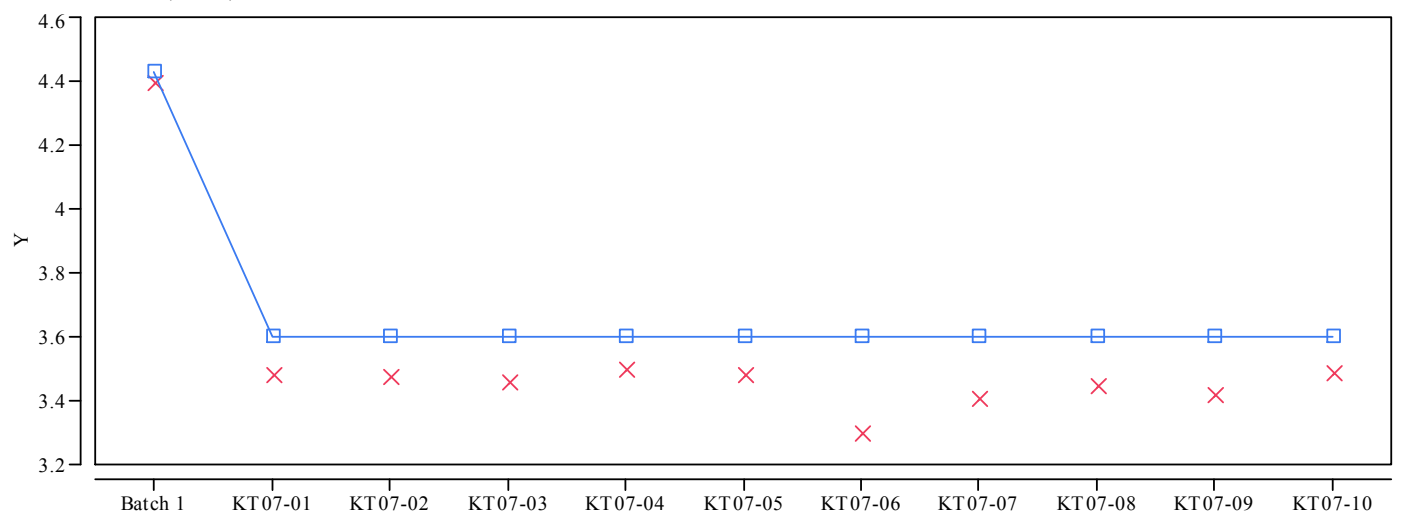

Glass ID

Y $\times$ Measured $\square$ T Targeted

\section{Oxide $=\operatorname{MgO}(\mathrm{wt} \%)$}

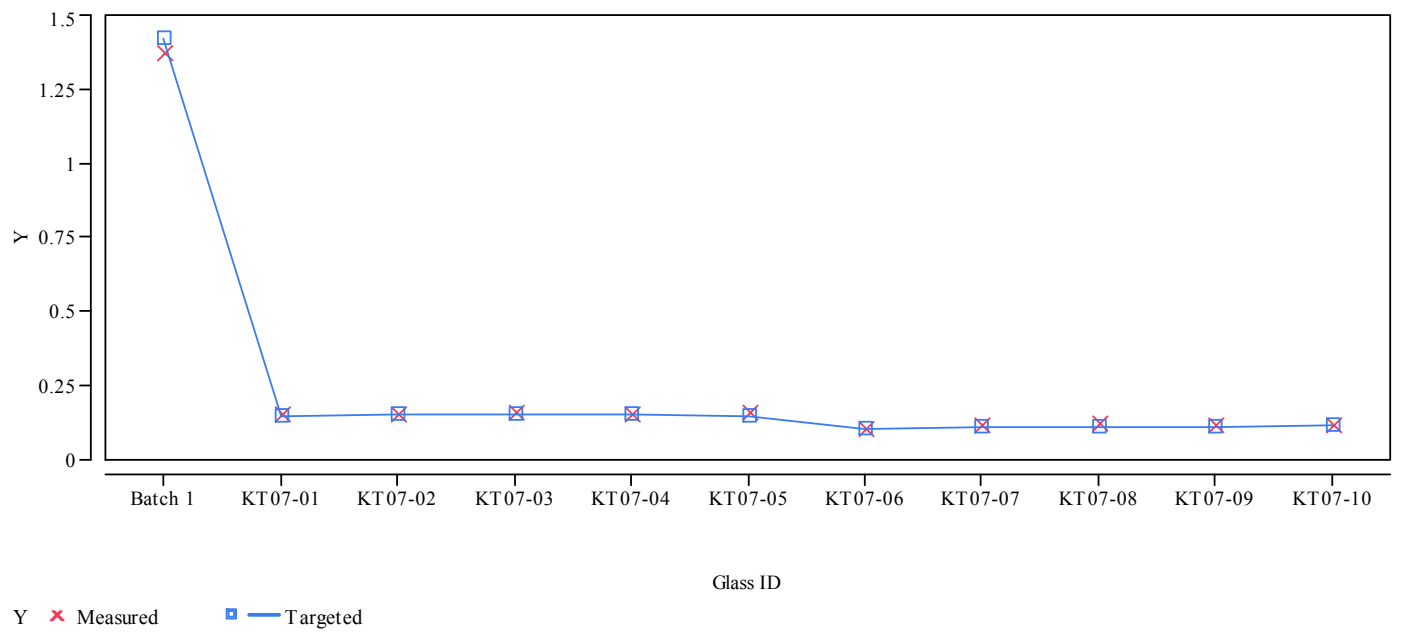


SRNL-STI-2010-00759

Revision 0

Exhibit A-4. Plots of Measured versus Targeted Concentrations by Glass ID by Oxide. (continued)

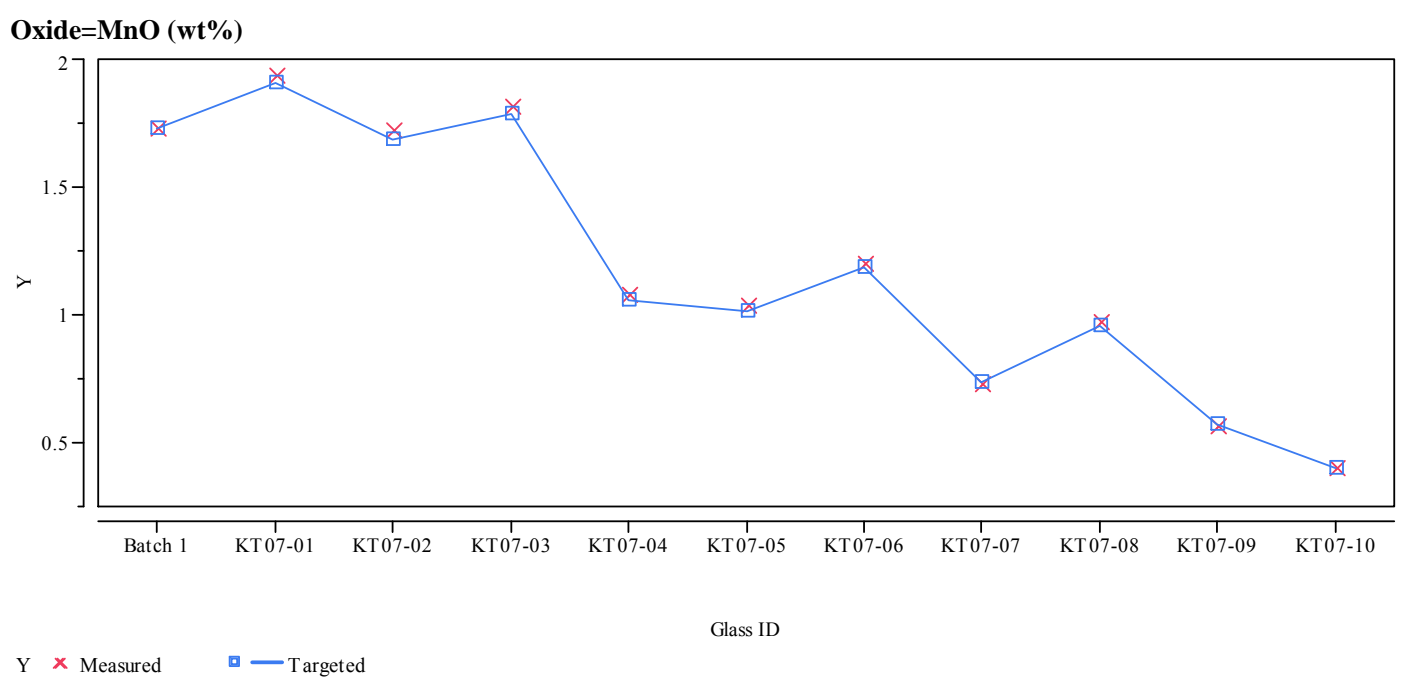

Oxide=Na2O (wt\%)
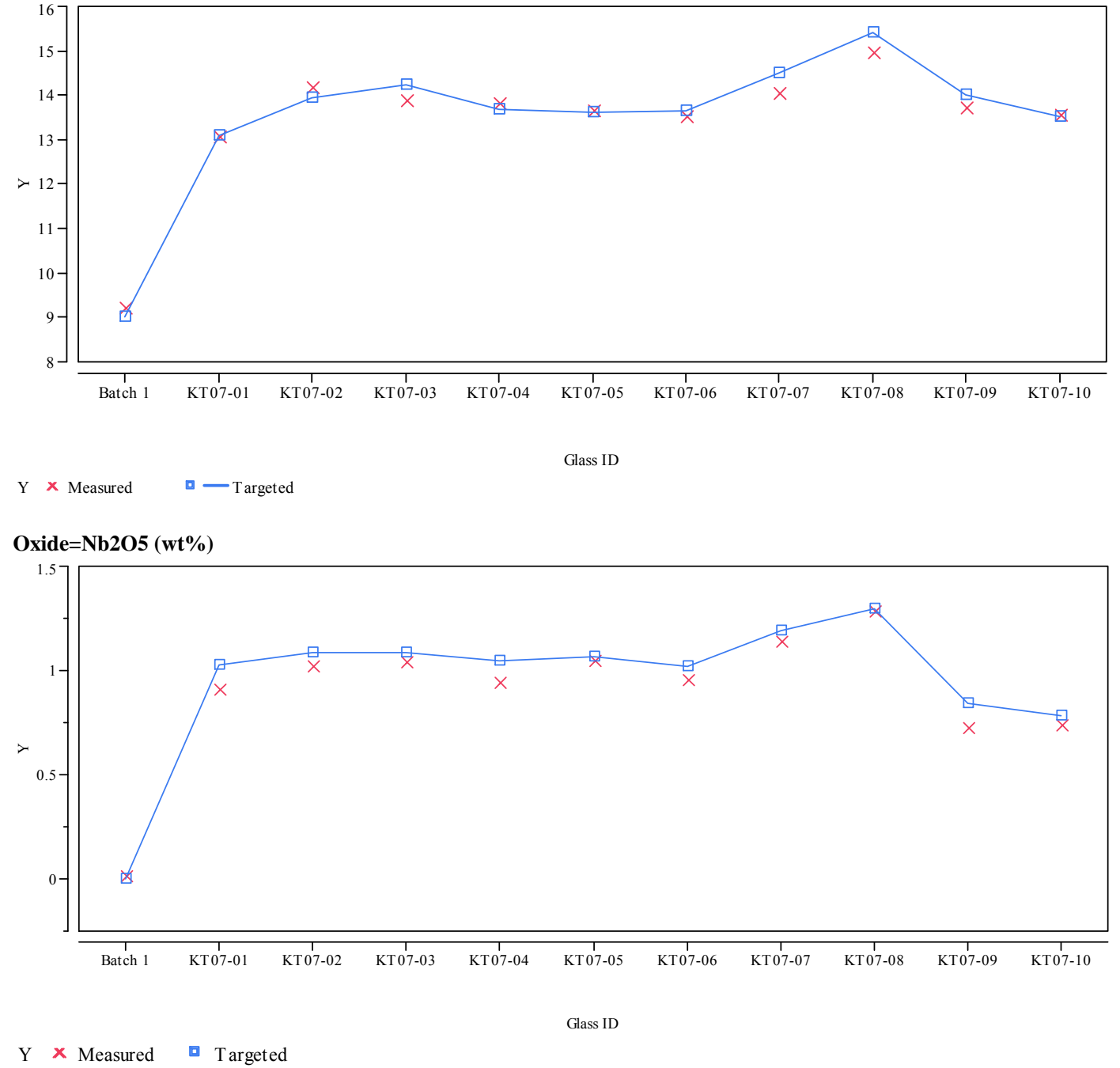
Exhibit A-4. Plots of Measured versus Targeted Concentrations by Glass ID by Oxide. (continued)

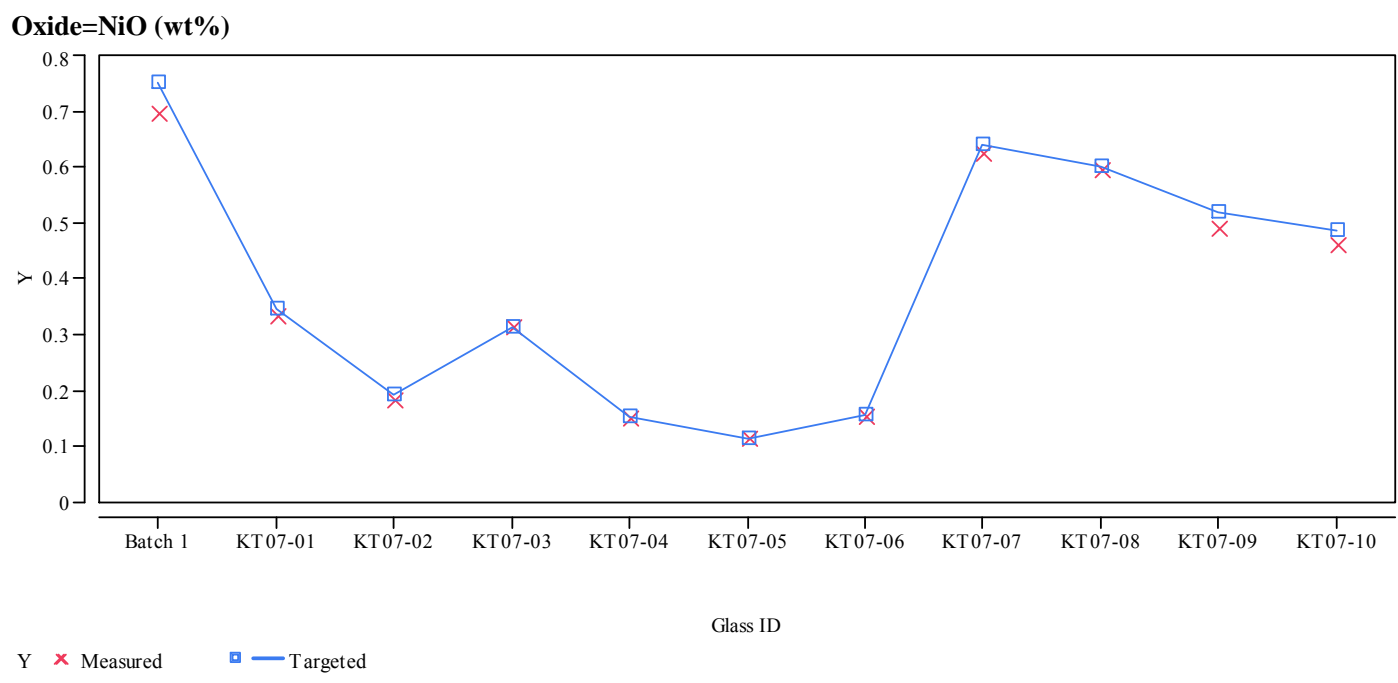

Oxide=PbO (wt \%)

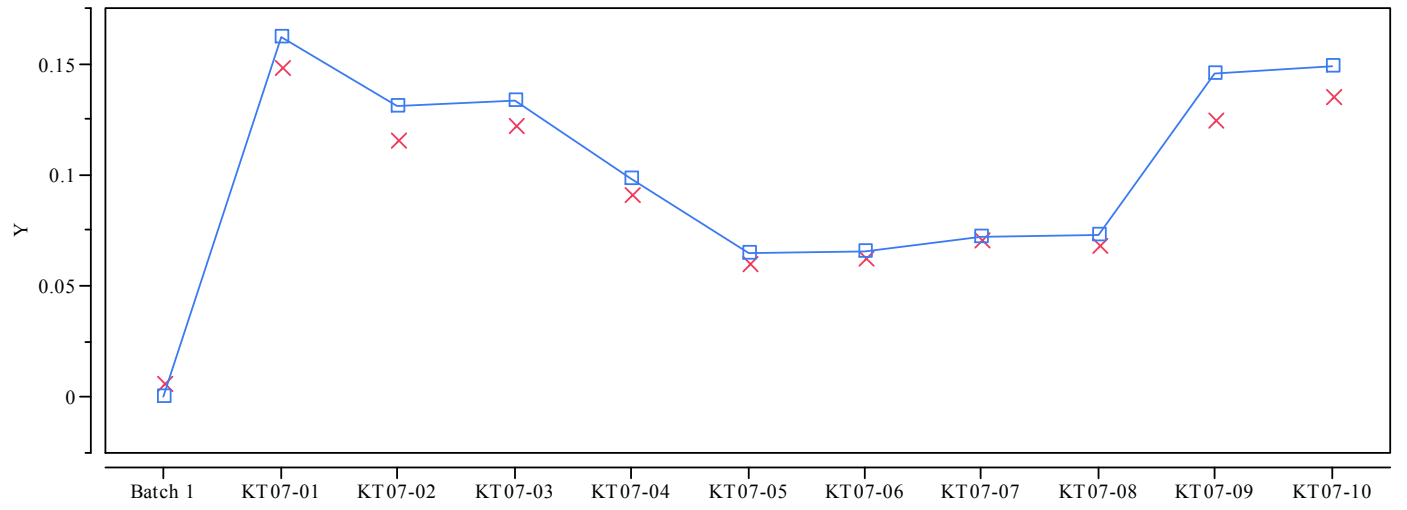

Glass ID

$\mathrm{Y} \times$ Measured $\square-$ Targeted

Oxide $=\mathrm{SiO} 2(\mathrm{wt} \%)$

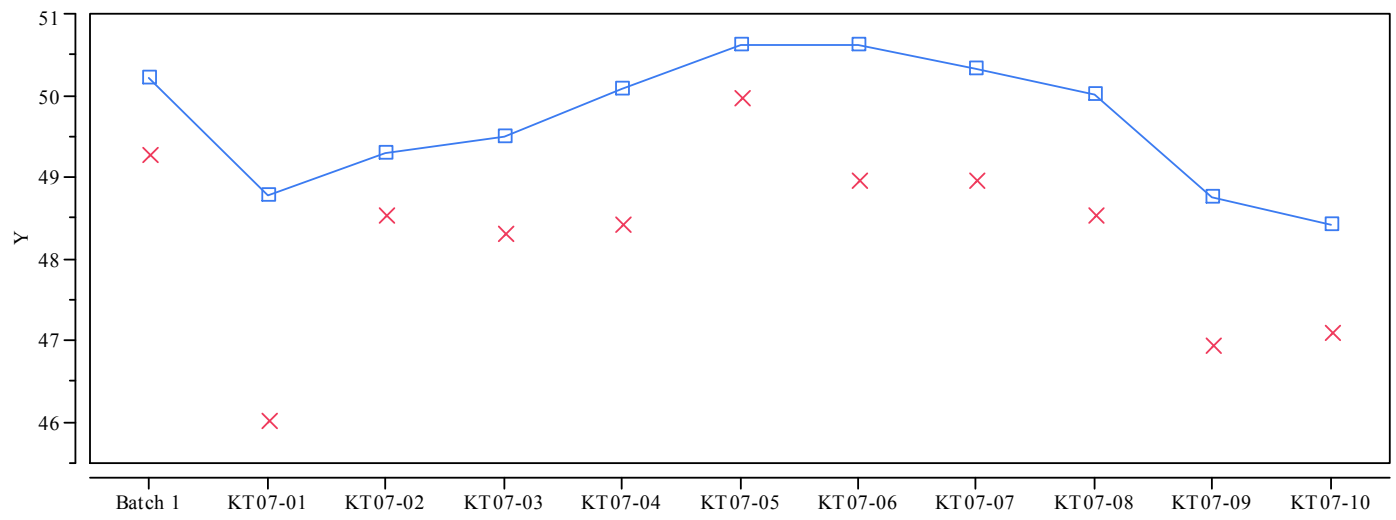

Glass ID

$\mathrm{Y} \times$ Measured $\square-$ Targeted 
Exhibit A-4. Plots of Measured versus Targeted Concentrations by Glass ID by Oxide. (continued)

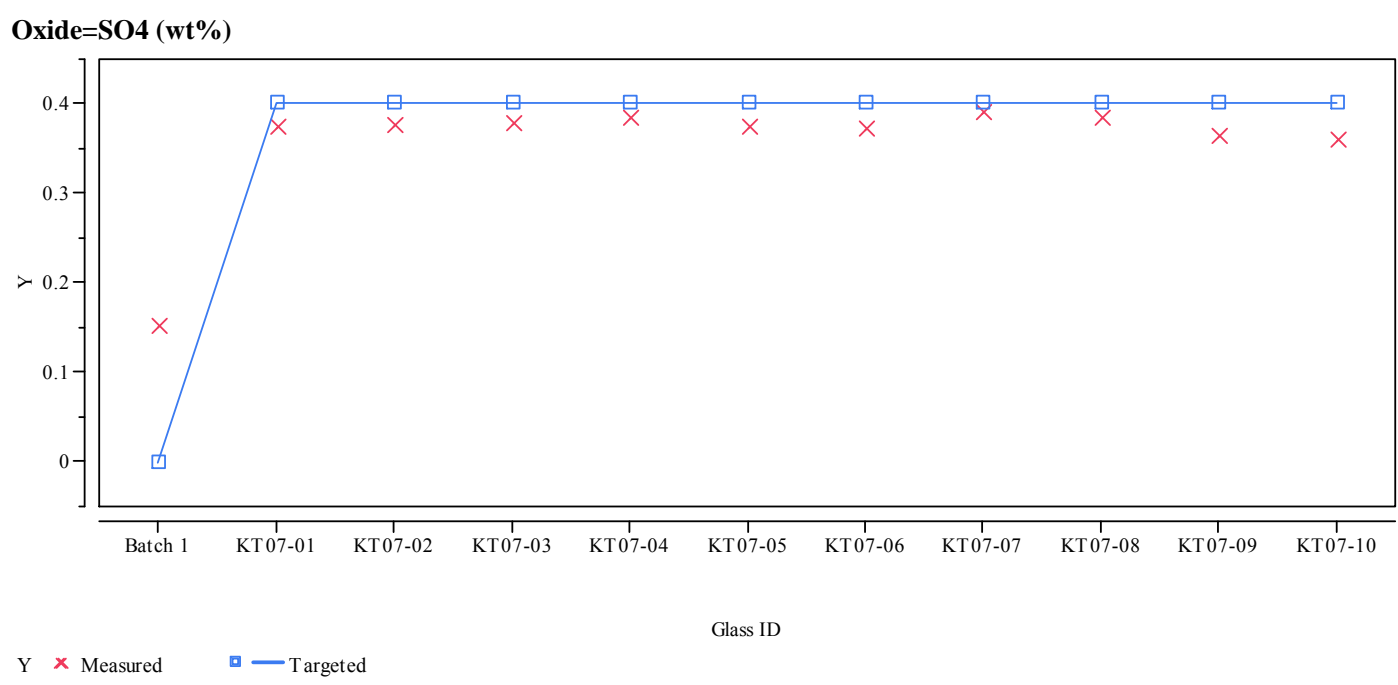

Oxide=TiO2 (wt\%)

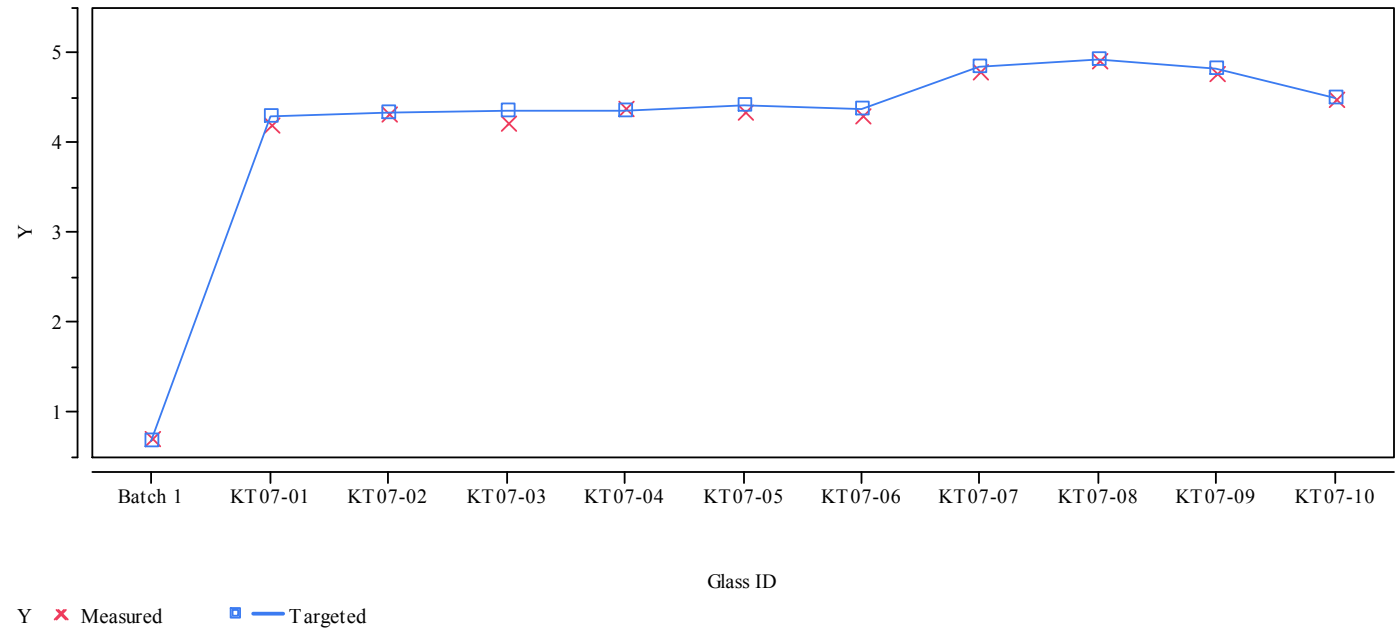

Oxide $=\mathrm{ZnO}(\mathrm{wt} \%)$

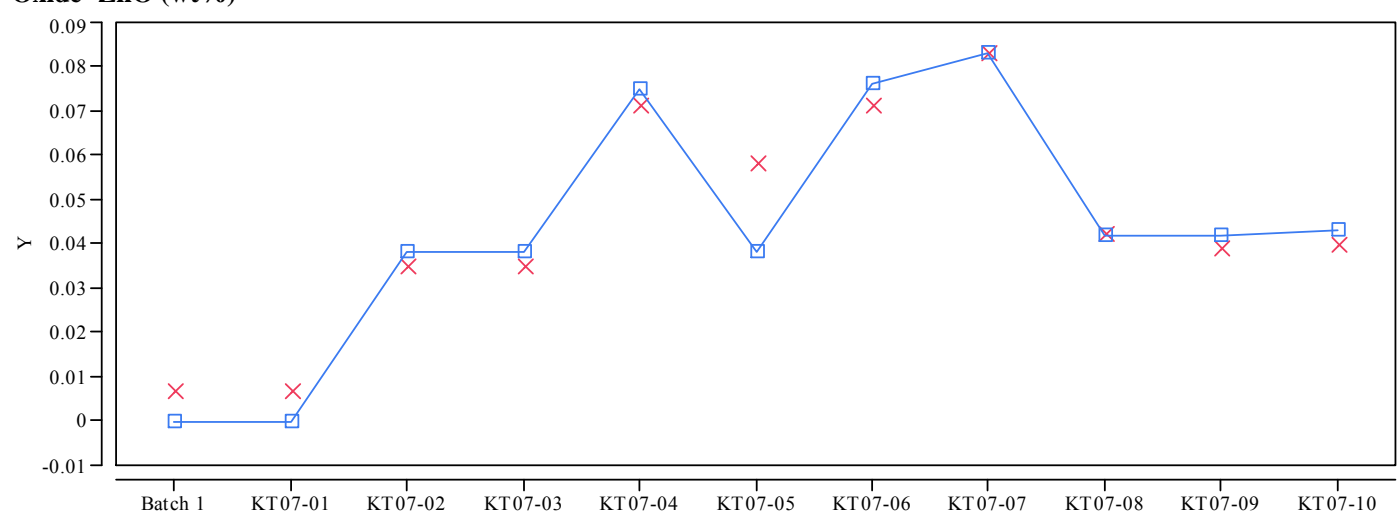

$\mathrm{Y} \times$ Measured $\square-\mathrm{Targeted}$

Glass ID 
SRNL-STI-2010-00759

Revision 0

Exhibit A-4. Plots of Measured versus Targeted Concentrations by Glass ID by Oxide. (continued)

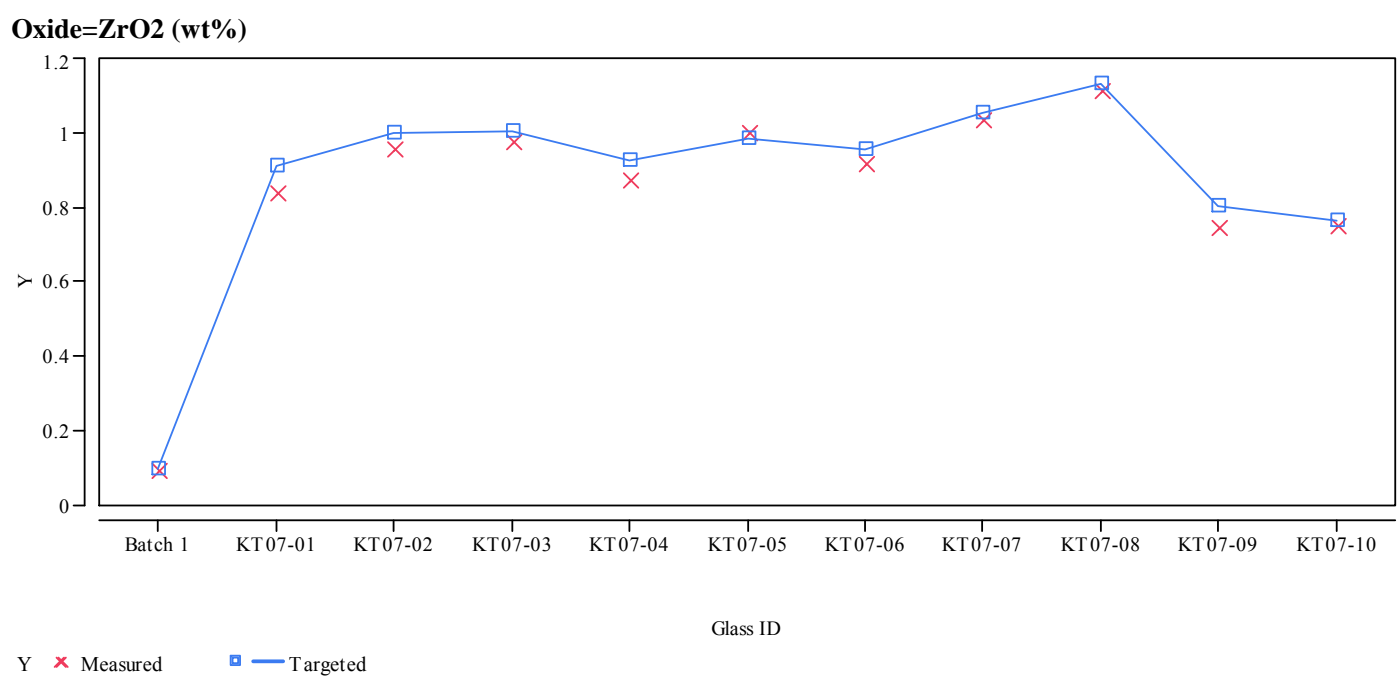

Oxide $=$ Sum of Oxides

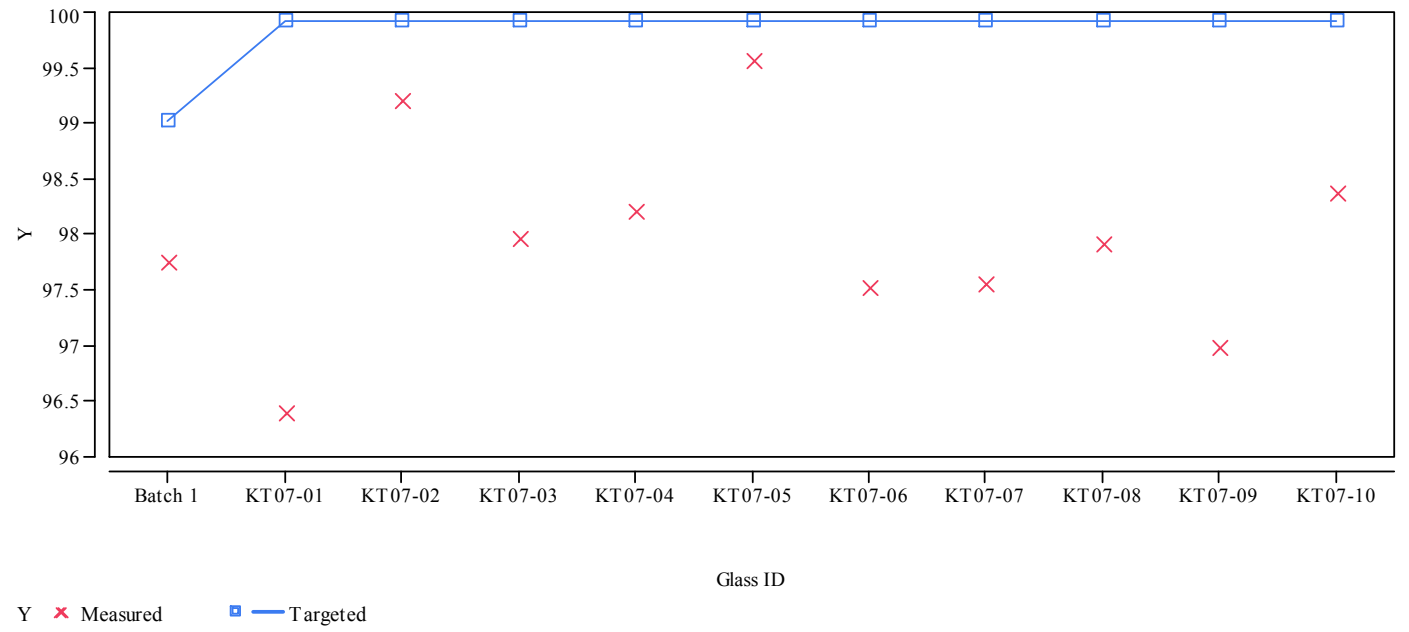


SRNL-STI-2010-00759

Revision 0

Appendix B. Data Supporting the PCT Measurements

of the KT07-Series Glasses 
Table B-1. PCT Measurement Data for the KT07 Glasses from PSAL, As Received (ar) and Parts per Million (ppm).

\begin{tabular}{|c|c|c|c|c|c|c|c|c|c|c|c|c|}
\hline Glass ID & Heat Treatment & Block & Seq & Lab ID & B ar & Li ar & Na ar & Si ar & B (ppm) & Li (ppm) & $\mathrm{Na}$ (ppm) & Si (ppm) \\
\hline Soln Std & ref & 1 & 1 & std-11 & 21.6 & 10.2 & \begin{tabular}{|l|}
83.1 \\
\end{tabular} & \begin{tabular}{|l|}
49.9 \\
\end{tabular} & 21.60 & 10.20 & 83.10 & 49.90 \\
\hline KT07-01 & quenched & 1 & 2 & $\mathrm{~h} 33$ & 6.79 & 7.04 & \begin{tabular}{|l|}
36.8 \\
\end{tabular} & 56.4 & 11.32 & 11.73 & 61.33 & 94.00 \\
\hline KT07-03 & $\mathrm{ccc}$ & 1 & 3 & $\mathrm{~h} 10$ & 7.35 & 7.25 & \begin{tabular}{|l|}
44.1 \\
\end{tabular} & 60.2 & 12.25 & 12.08 & 73.50 & 100.34 \\
\hline KT07-05 & $\mathrm{ccc}$ & 1 & 4 & h39 & 5.61 & 6.13 & \begin{tabular}{|l|}
32.8 \\
\end{tabular} & 54.0 & 9.35 & 10.22 & 54.67 & 90.00 \\
\hline KT07-04 & $\mathrm{ccc}$ & 1 & 5 & h06 & 6.75 & 6.90 & \begin{tabular}{|l|}
38.2 \\
\end{tabular} & 58.8 & 11.25 & 11.50 & 63.67 & 98.00 \\
\hline KT07-03 & quenched & 1 & 6 & h08 & 7.34 & 7.20 & 46.6 & 60.1 & 12.23 & 12.00 & 77.67 & 100.17 \\
\hline KT07-08 & quenched & 1 & 7 & h16 & 6.99 & 6.94 & \begin{tabular}{|l|}
55.1 \\
\end{tabular} & 65.5 & 11.65 & 11.57 & 91.84 & 109.17 \\
\hline KT07-09 & $\mathrm{ccc}$ & 1 & 8 & h36 & 6.67 & 6.85 & \begin{tabular}{|l|}
40.2 \\
\end{tabular} & 57.8 & 11.12 & 11.42 & 67.00 & 96.34 \\
\hline KT07-10 & $\mathrm{ccc}$ & 1 & 9 & $\mathrm{~h} 02$ & 7.23 & 7.54 & 40.3 & 62.1 & 12.05 & 12.57 & 67.17 & 103.50 \\
\hline EA & ref & 1 & 10 & h52 & 34.6 & 11.3 & \begin{tabular}{|l|}
95.5 \\
\end{tabular} & 52.9 & 576.67 & 188.33 & 1591.67 & 881.67 \\
\hline KT07-06 & $\mathrm{ccc}$ & 1 & 11 & $\mathrm{~h} 42$ & 5.77 & 6.05 & \begin{tabular}{|l|}
32.6 \\
\end{tabular} & 53.8 & 9.62 & 10.08 & 54.33 & 89.67 \\
\hline KT07-07 & quenched & 1 & 12 & h49 & 6.53 & 6.63 & \begin{tabular}{|l|}
45.4 \\
\end{tabular} & 61.9 & 10.88 & 1.05 & 75.67 & 103.17 \\
\hline KT07-04 & quenched & 1 & 13 & h13 & 6.67 & 7.01 & \begin{tabular}{|l|}
40.5 \\
\end{tabular} & 58.8 & 11.12 & 1.68 & 7.50 & 98.00 \\
\hline Soln Std & ref & 1 & 14 & std-12 & 21.2 & 10.5 & \begin{tabular}{|l|}
85.5 \\
\end{tabular} & 50.7 & 21.20 & 0.50 & 5.50 & 50.70 \\
\hline KT07-09 & quenched & 1 & 15 & $\mathrm{~h} 60$ & 7.79 & 7.51 & \begin{tabular}{|l|}
46.4 \\
\end{tabular} & 63.1 & 12.98 & 2.52 & 77.33 & 105.17 \\
\hline ARM-1 & ref & 1 & 16 & h01 & 10.9 & \begin{tabular}{|l|}
8.50 \\
\end{tabular} & 22.0 & 35.8 & 18.17 & 4.17 & 5.67 & 59.67 \\
\hline KT07-06 & quenched & 1 & 17 & h57 & 6.12 & 7.11 & \begin{tabular}{|l|}
39.3 \\
\end{tabular} & 57.0 & 10.20 & 1.85 & 5.50 & 95.00 \\
\hline KT07-02 & quenched & 1 & 18 & $\mathrm{~h} 47$ & 7.18 & \begin{tabular}{|l|}
7.37 \\
\end{tabular} & \begin{tabular}{|l|}
44.3 \\
\end{tabular} & 60.5 & 11.97 & 2.28 & 3.83 & 100.84 \\
\hline KT07-10 & quenched & 1 & 19 & h14 & 7.29 & 7.62 & \begin{tabular}{|l|}
42.4 \\
\end{tabular} & 61.4 & 12.15 & 2.70 & 70.67 & 102.34 \\
\hline KT07-07 & $\mathrm{ccc}$ & 1 & 20 & h66 & 6.16 & 6.41 & \begin{tabular}{|l|}
40.7 \\
\end{tabular} & 58.1 & 10.27 & 10.68 & 67.83 & 96.84 \\
\hline blank & ref & 1 & 21 & $\mathrm{~h} 31$ & 0.554 & $<1.00$ & 0.331 & 0.123 & 0.92 & 0.83 & 0.55 & 0.21 \\
\hline KT07-05 & quenche & 1 & 22 & h62 & 5.72 & \begin{tabular}{|l|}
6.49 \\
\end{tabular} & 36.2 & 56.7 & 9.53 & 10.82 & 0.33 & 94.50 \\
\hline KT07-08 & $\mathrm{ccc}$ & 1 & 23 & $\mathrm{~h} 20$ & 7.01 & 7.34 & \begin{tabular}{|l|}
52.3 \\
\end{tabular} & 66.3 & 11.68 & 2.23 & 7.17 & 110.50 \\
\hline KT07-02 & $\mathrm{ccc}$ & 1 & 24 & $\mathrm{~h} 28$ & 6.96 & \begin{tabular}{|l|}
7.08 \\
\end{tabular} & 40.5 & 57.0 & 11.60 & 1.80 & 7.50 & 95.00 \\
\hline KT07-01 & $\mathrm{ccc}$ & 1 & 25 & h18 & 6.97 & 7.28 & \begin{tabular}{|l|}
36.9 \\
\end{tabular} & 56.8 & 11.62 & 2.13 & 1.50 & 4.67 \\
\hline Soln Std & ref & 1 & 26 & std-13 & 21.0 & \begin{tabular}{|l|}
10.6 \\
\end{tabular} & \begin{tabular}{|l|}
86.7 \\
\end{tabular} & 51.2 & 21.00 & 0.60 & 6.70 & 51.20 \\
\hline Soln Std & ref & 2 & 1 & std-21 & 20.1 & 10.1 & \begin{tabular}{|l|}
85.1 \\
\end{tabular} & 49.1 & 20.10 & 10.10 & 5.10 & 49.10 \\
\hline KT07-06 & ench & 2 & 2 & h03 & 5.07 & 5.90 & \begin{tabular}{|l|}
33.2 \\
\end{tabular} & 51.7 & 8.45 & 9.83 & 5.33 & 86.17 \\
\hline KT07-06 & $\mathrm{ccc}$ & 2 & 3 & h26 & \begin{tabular}{|l|}
4.92 \\
\end{tabular} & \begin{tabular}{|l|}
5.94 \\
\end{tabular} & \begin{tabular}{|l|}
32.1 \\
\end{tabular} & 53.3 & 8.20 & 9.90 & 3.50 & 88.84 \\
\hline KT07-08 & quenched & 2 & 4 & $\mathrm{~h} 43$ & 6.44 & \begin{tabular}{|l|}
6.98 \\
\end{tabular} & 56.9 & 64.9 & 10.73 & 11.63 & 94.84 & 108.17 \\
\hline KT07-02 & quenched & 2 & 5 & $\mathrm{~h} 61$ & 6.11 & 6.85 & \begin{tabular}{|l|}
41.8 \\
\end{tabular} & 56.7 & 10.18 & 1.42 & 69.67 & 94.50 \\
\hline KT07-03 & $\mathrm{ccc}$ & 2 & 6 & h68 & 6.50 & 7.00 & \begin{tabular}{|l|}
43.1 \\
\end{tabular} & 58.1 & 10.83 & 1.67 & 1.83 & 96.84 \\
\hline KT07-01 & $\mathrm{ccc}$ & 2 & 7 & h58 & \begin{tabular}{|l|}
6.09 \\
\end{tabular} & \begin{tabular}{|l|}
6.91 \\
\end{tabular} & 35.9 & 54.9 & 10.15 & 1.52 & 99.83 & 91.50 \\
\hline KT07-08 & $\mathrm{ccc}$ & 2 & 8 & h41 & 6.16 & \begin{tabular}{|l|}
6.90 \\
\end{tabular} & \begin{tabular}{|l|}
50.2 \\
\end{tabular} & 63.0 & 10.27 & 1.50 & 33.67 & 105.00 \\
\hline $\begin{array}{l}\text { KT07-04 } \\
\end{array}$ & quenche & 2 & 9 & h53 & \begin{tabular}{|l|}
5.88 \\
\end{tabular} & \begin{tabular}{|l|}
6.75 \\
\end{tabular} & \begin{tabular}{|l|}
40.2 \\
\end{tabular} & \begin{tabular}{|l|}
57.4 \\
\end{tabular} & 9.80 & 1.25 & 57.00 & 95.67 \\
\hline \begin{tabular}{|l|} 
KT07-05 \\
\end{tabular} & $\mathrm{ccc}$ & 2 & 10 & h23 & 4.85 & \begin{tabular}{|l|}
6.02 \\
\end{tabular} & \begin{tabular}{|l|}
33.0 \\
\end{tabular} & \begin{tabular}{|l|}
53.1 \\
\end{tabular} & 8.08 & 0.03 & 5.00 & 88.50 \\
\hline KT07-05 & quenched & 2 & 11 & h59 & 4.78 & 6.05 & \begin{tabular}{|l|}
34.1 \\
\end{tabular} & \begin{tabular}{|l|}
52.9 \\
\end{tabular} & 7.97 & 10.08 & 56.83 & 88.17 \\
\hline $\begin{array}{l}\text { KT07-07 } \\
\end{array}$ & quenched & 2 & 12 & h30 & 5.65 & \begin{tabular}{|l|}
6.48 \\
\end{tabular} & \begin{tabular}{|l|}
44.6 \\
\end{tabular} & \begin{tabular}{|l|}
60.1 \\
\end{tabular} & 9.42 & 10.80 & 74.33 & 100.17 \\
\hline \begin{tabular}{|l|} 
KT07-01 \\
\end{tabular} & quenched & 2 & 13 & h64 & \begin{tabular}{|l|}
5.70 \\
\end{tabular} & \begin{tabular}{|l|}
6.89 \\
\end{tabular} & \begin{tabular}{|l|}
35.8 \\
\end{tabular} & \begin{tabular}{|l|}
54.6 \\
\end{tabular} & 9.50 & 1.48 & 99.67 & 91.00 \\
\hline Soln Std & ref & 2 & 14 & std-22 & 19.6 & \begin{tabular}{|l|}
10.1 \\
\end{tabular} & \begin{tabular}{|l|}
84.6 \\
\end{tabular} & \begin{tabular}{|l|}
49.3 \\
\end{tabular} & 19.60 & 10.10 & 84.60 & 49.30 \\
\hline KT07-04 & $\mathrm{ccc}$ & 2 & 15 & h67 & \begin{tabular}{|l|}
6.31 \\
\end{tabular} & \begin{tabular}{|l|}
6.66 \\
\end{tabular} & \begin{tabular}{|l|}
37.8 \\
\end{tabular} & \begin{tabular}{|l|}
56.8 \\
\end{tabular} & 10.52 & 11.10 & 63.00 & 94.67 \\
\hline \begin{tabular}{|l|} 
KT07-09 \\
\end{tabular} & quenched & 2 & 16 & h17 & \begin{tabular}{|l|}
6.72 \\
\end{tabular} & 7.22 & \begin{tabular}{|l|}
45.9 \\
\end{tabular} & \begin{tabular}{|l|}
60.9 \\
\end{tabular} & 11.20 & 2.03 & 76.50 & 101.50 \\
\hline KT07-10 & quenched & 2 & 17 & h05 & 6.59 & \begin{tabular}{|l|}
7.39 \\
\end{tabular} & \begin{tabular}{|l|}
42.2 \\
\end{tabular} & 60.5 & 10.98 & 12.32 & 70.33 & 100.84 \\
\hline KT07-02 & $\mathrm{ccc}$ & 2 & 18 & h54 & \begin{tabular}{|l|}
6.00 \\
\end{tabular} & \begin{tabular}{|l|}
6.61 \\
\end{tabular} & \begin{tabular}{|l|}
38.7 \\
\end{tabular} & \begin{tabular}{|l|}
54.1 \\
\end{tabular} & 10.00 & 11.02 & 64.50 & 90.17 \\
\hline EA & ref & 2 & 19 & h09 & \begin{tabular}{|l|}
31.0 \\
\end{tabular} & \begin{tabular}{|l|}
10.4 \\
\end{tabular} & \begin{tabular}{|l|}
88.6 \\
\end{tabular} & 49.2 & 516.67 & 173.33 & 1476.67 & 820.00 \\
\hline KT07-09 & $\mathrm{ccc}$ & 2 & 20 & h48 & 6.31 & 7.00 & \begin{tabular}{|l|}
42.0 \\
\end{tabular} & 59.5 & 10.52 & 11.67 & 70.00 & 99.17 \\
\hline $\begin{array}{l}\text { KT07-07 } \\
\end{array}$ & $\mathrm{ccc}$ & 2 & 21 & h44 & 5.33 & \begin{tabular}{|l|}
6.11 \\
\end{tabular} & \begin{tabular}{|l|}
39.4 \\
\end{tabular} & \begin{tabular}{|l|}
55.8 \\
\end{tabular} & 8.88 & 10.18 & 65.67 & 93.00 \\
\hline \begin{tabular}{|l|} 
ARM-1 \\
\end{tabular} & ref & 2 & 22 & h22 & \begin{tabular}{|l|}
9.88 \\
\end{tabular} & \begin{tabular}{|l|}
8.22 \\
\end{tabular} & \begin{tabular}{|l|}
21.5 \\
\end{tabular} & 35.1 & 16.47 & 13.70 & 35.83 & 58.50 \\
\hline KT07-10 & $\mathrm{ccc}$ & 2 & 23 & h27 & \begin{tabular}{|l|}
6.17 \\
\end{tabular} & \begin{tabular}{|l|}
7.12 \\
\end{tabular} & \begin{tabular}{|l|}
38.6 \\
\end{tabular} & 57.8 & 10.28 & 11.87 & 64.33 & 96.34 \\
\hline \begin{tabular}{|l|} 
KT07-03 \\
\end{tabular} & quenche & 2 & 24 & h34 & \begin{tabular}{|l|}
6.49 \\
\end{tabular} & \begin{tabular}{|l|}
7.13 \\
\end{tabular} & \begin{tabular}{|l|}
46.8 \\
\end{tabular} & \begin{tabular}{|l|}
59.8 \\
\end{tabular} & 10.82 & 11.88 & 78.00 & 99.67 \\
\hline Soln Std & ref & 2 & 25 & std-23 & \begin{tabular}{|l|}
19.7 \\
\end{tabular} & \begin{tabular}{|l|}
10.1 \\
\end{tabular} & \begin{tabular}{|l|}
85.1 \\
\end{tabular} & \begin{tabular}{|l|}
49.9 \\
\end{tabular} & 19.70 & 10.10 & 85.10 & 49.90 \\
\hline Soln Std & ref & 3 & 1 & std-31 & \begin{tabular}{|l|}
20.7 \\
\end{tabular} & 9.9 & \begin{tabular}{|l|l|}
83.1 & \\
\end{tabular} & 48.9 & 20.70 & 9.90 & 83.10 & 48.90 \\
\hline \begin{tabular}{|l|} 
KT07-01 \\
\end{tabular} & quenched & 3 & 2 & h32 & \begin{tabular}{|l|}
6.40 \\
\end{tabular} & \begin{tabular}{|l|}
6.99 \\
\end{tabular} & \begin{tabular}{|l|}
37.1 \\
\end{tabular} & \begin{tabular}{|l|l|}
55.7 \\
\end{tabular} & 10.67 & 11.65 & 61.83 & 92.84 \\
\hline \begin{tabular}{|l|} 
KT07-04 \\
\end{tabular} & quenched & 3 & 3 & h29 & 6.25 & \begin{tabular}{|l|}
6.94 \\
\end{tabular} & \begin{tabular}{|l|}
41.0 \\
\end{tabular} & \begin{tabular}{|l|}
60.0 \\
\end{tabular} & 10.42 & 11.57 & 68.33 & 100.00 \\
\hline KT07-09 & quenched & 3 & 4 & h24 & 6.23 & \begin{tabular}{|l|}
7.12 \\
\end{tabular} & \begin{tabular}{|l|}
45.2 \\
\end{tabular} & \begin{tabular}{|l|}
61.0 \\
\end{tabular} & 10.38 & 11.87 & 75.33 & 101.67 \\
\hline \begin{tabular}{|l|} 
KT07-02 \\
\end{tabular} & $\mathrm{ccc}$ & 3 & 5 & h15 & \begin{tabular}{|l|}
6.20 \\
\end{tabular} & \begin{tabular}{|l|}
7.00 \\
\end{tabular} & \begin{tabular}{|l|}
41.0 \\
\end{tabular} & \begin{tabular}{|l|}
57.0 \\
\end{tabular} & 10.33 & 11.67 & 68.33 & 95.00 \\
\hline \begin{tabular}{|l|} 
KT07-02 \\
\end{tabular} & quenched & 3 & 6 & h19 & \begin{tabular}{|l|}
6.04 \\
\end{tabular} & \begin{tabular}{|l|}
7.06 \\
\end{tabular} & \begin{tabular}{|l|}
43.6 \\
\end{tabular} & \begin{tabular}{|l|}
59.1 \\
\end{tabular} & 10.07 & 11.77 & 72.67 & 98.50 \\
\hline KT07-06 & quenched & 3 & 7 & h63 & 4.45 & 5.96 & \begin{tabular}{|l|}
34.0 \\
\end{tabular} & 53.8 & 7.42 & 9.93 & 56.67 & 89.67 \\
\hline \begin{tabular}{|l|} 
KT07-01 \\
\end{tabular} & $\mathrm{ccc}$ & 3 & 8 & $\mathrm{~h} 35$ & \begin{tabular}{|l|}
5.77 \\
\end{tabular} & \begin{tabular}{|l|}
6.86 \\
\end{tabular} & \begin{tabular}{|l|}
35.6 \\
\end{tabular} & 55.6 & 9.62 & 11.43 & 59.33 & 92.67 \\
\hline
\end{tabular}


Table B-1. PCT Measurement Data for the KT07 Glasses from PSAL, As Received (ar) and Parts per Million (ppm). (continued)

\begin{tabular}{|c|c|c|c|c|c|c|c|c|c|c|c|c|}
\hline Glass ID & Heat Treatment & Block & Seq & Lab ID & B ar & Li ar & Na ar & Si ar & B (ppm) & Li (ppm) & $\mathrm{Na}(\mathrm{ppm})$ & Si (ppm) \\
\hline KT07-08 & quenched & 3 & 9 & h46 & 5.99 & 6.90 & 56.9 & 64.6 & 9.98 & 11.50 & 94.84 & 107.67 \\
\hline EA & ref & 3 & 10 & h40 & 28.8 & 9.80 & 82.4 & 46.8 & 480.00 & 163.33 & 1373.34 & 780.00 \\
\hline blank & ref & 3 & 11 & $\mathrm{~h} 25$ & $<0.100$ & $<1.00$ & $<0.100$ & 0.129 & 0.08 & 0.83 & 0.08 & 0.22 \\
\hline KT07-03 & quenched & 3 & 12 & h51 & 6.17 & 6.89 & 45.5 & 58.1 & 10.28 & 11.48 & 75.83 & 96.84 \\
\hline ARM-1 & ref & 3 & 13 & h38 & 9.55 & 8.05 & 20.7 & 34.4 & 15.92 & 13.42 & 34.50 & 57.33 \\
\hline Soln Std & ref & 3 & 14 & std-32 & 19.8 & 9.95 & 83.5 & 49.0 & 19.80 & 9.95 & 83.50 & 49.00 \\
\hline \begin{tabular}{|l|} 
KT07-03 \\
\end{tabular} & $\mathrm{ccc}$ & 3 & 15 & h56 & 6.76 & 7.19 & 44.2 & 60.7 & 11.27 & 11.98 & 73.67 & 101.17 \\
\hline KT07-08 & ccc & 3 & 16 & h21 & 5.89 & 6.80 & 49.7 & 62.5 & 9.82 & 11.33 & 82.83 & 104.17 \\
\hline \begin{tabular}{|l|} 
KT07-09 \\
\end{tabular} & $\mathrm{ccc}$ & 3 & 17 & h65 & 5.94 & 6.96 & 41.9 & 59.1 & 9.90 & 11.60 & 69.83 & 98.50 \\
\hline \begin{tabular}{|l|} 
KT07-10 \\
\end{tabular} & quenched & 3 & 18 & $\mathrm{~h} 45$ & 5.89 & 7.01 & 39.7 & 57.3 & 9.82 & 11.68 & 66.17 & 95.50 \\
\hline \begin{tabular}{|l|} 
KT07-05 \\
\end{tabular} & quenched & 3 & 19 & h55 & 4.60 & 6.16 & 35.1 & 54.9 & 7.67 & 10.27 & 58.50 & 91.50 \\
\hline KT07-10 & $\mathrm{ccc}$ & 3 & 20 & h37 & 5.83 & 7.03 & 38.2 & 58.9 & 9.72 & 11.72 & 63.67 & 98.17 \\
\hline KT07-06 & $\mathrm{ccc}$ & 3 & 21 & h50 & 4.53 & 6.00 & 33.0 & 54.3 & 7.55 & 10.00 & 55.00 & 90.50 \\
\hline \begin{tabular}{|l|} 
KT07-07 \\
\end{tabular} & quenched & 3 & 22 & h11 & 5.15 & 6.28 & 43.8 & 58.9 & 8.58 & 10.47 & 73.00 & 98.17 \\
\hline KT07-07 & $\mathrm{ccc}$ & 3 & 23 & h04 & 5.24 & 6.43 & 41.9 & 58.7 & 8.73 & 10.72 & 69.83 & 97.84 \\
\hline KT07-04 & ccc & 3 & 24 & h07 & 5.54 & 6.75 & 38.1 & 57.7 & 9.23 & 11.25 & 63.50 & 96.17 \\
\hline KT07-05 & ccc & 3 & 25 & h12 & 4.71 & 6.27 & 34.6 & 56.5 & 7.85 & 10.45 & 57.67 & 94.17 \\
\hline Soln Std & ref & 3 & 26 & std-33 & 19.8 & 10.1 & 85.8 & 50.3 & 19.80 & 10.10 & 85.80 & 50.30 \\
\hline
\end{tabular}


Table B-2. Normalized PCT Responses for the KT07-Series Glasses.

\begin{tabular}{|c|c|c|c|c|c|c|c|c|c|c|}
\hline Glass ID & $\begin{array}{c}\text { Heat } \\
\text { Treatment }\end{array}$ & $\begin{array}{l}\text { Comp } \\
\text { View } \\
\end{array}$ & $\begin{array}{c}\log N L \\
B(g / L)] \\
\end{array}$ & $\begin{array}{c}\log N \mathrm{~L} \\
{[\mathrm{Li}(\mathrm{g} / \mathrm{L})]}\end{array}$ & $\begin{array}{c}\log \mathrm{NL} \\
{[\mathrm{Na}(\mathrm{g} / \mathrm{L})]}\end{array}$ & $\begin{array}{c}\log N L \\
{[S i(g / L)]}\end{array}$ & $\begin{array}{c}\text { NL } \\
\text { B(g/L) }\end{array}$ & $\begin{array}{c}\text { NL } \\
\mathrm{Li}(\mathrm{g} / \mathrm{L})\end{array}$ & $\begin{array}{c}\text { NL } \\
\mathrm{Na}(\mathrm{g} / \mathrm{L}) \\
\end{array}$ & $\begin{array}{c}\text { NL } \\
\mathrm{Si}(\mathrm{g} / \mathrm{L})\end{array}$ \\
\hline ARM & ref & reference & -0.3193 & -0.2343 & -0.3036 & -0.5701 & 0.479 & 0.583 & 0.497 & 0.269 \\
\hline EA & ref & reference & 1.1732 & 0.9459 & 1.0740 & 0.5595 & 14.901 & 8.829 & 11.858 & 3.627 \\
\hline KT07-01 & $\mathrm{ccc}$ & targeted & -0.2520 & -0.1553 & -0.2079 & -0.3897 & 0.560 & 0.699 & 0.620 & 0.408 \\
\hline KT07-02 & $\mathrm{ccc}$ & targeted & -0.2440 & -0.1629 & -0.1904 & -0.3923 & 0.570 & 0.687 & 0.645 & 0.405 \\
\hline KT07-03 & $\mathrm{ccc}$ & targeted & -0.2120 & -0.1473 & -0.1602 & -0.3668 & 0.614 & 0.712 & 0.691 & 0.430 \\
\hline KT07-04 & $\mathrm{ccc}$ & targeted & -0.2574 & -0.1708 & -0.2041 & -0.3860 & 0.553 & 0.675 & 0.625 & 0.411 \\
\hline KT07-05 & $\mathrm{ccc}$ & targeted & -0.3458 & -0.2132 & -0.2585 & -0.4157 & 0.451 & 0.612 & 0.551 & 0.384 \\
\hline KT07-06 & $\mathrm{ccc}$ & targeted & -0.3453 & -0.2234 & -0.2707 & -0.4214 & 0.452 & 0.598 & 0.536 & 0.379 \\
\hline KT07-07 & $\mathrm{ccc}$ & targeted & -0.3032 & -0.2009 & -0.2010 & -0.3899 & 0.498 & 0.630 & 0.630 & 0.407 \\
\hline KT07-08 & $\mathrm{ccc}$ & targeted & -0.2466 & -0.1556 & -0.1311 & -0.3413 & 0.567 & 0.699 & 0.739 & 0.456 \\
\hline KT07-09 & $\mathrm{ccc}$ & targeted & -0.2491 & -0.1602 & -0.1787 & -0.3666 & 0.564 & 0.692 & 0.663 & 0.430 \\
\hline KT07-10 & $\mathrm{ccc}$ & targeted & -0.2434 & -0.1424 & -0.1876 & -0.3579 & 0.571 & 0.721 & 0.649 & 0.439 \\
\hline KT07-01 & quenched & targeted & -0.2504 & -0.1579 & -0.2027 & -0.3913 & 0.562 & 0.695 & 0.627 & 0.406 \\
\hline KT07-02 & quenched & targeted & -0.2406 & -0.1507 & -0.1573 & -0.3716 & 0.575 & 0.707 & 0.696 & 0.425 \\
\hline KT07-03 & quenched & targeted & -0.2256 & -0.1518 & -0.1361 & -0.3692 & 0.595 & 0.705 & 0.731 & 0.427 \\
\hline KT07-04 & quenched & targeted & -0.2519 & -0.1625 & -0.1761 & -0.3788 & 0.560 & 0.688 & 0.667 & 0.418 \\
\hline KT07-05 & quenched & targeted & -0.3485 & -0.2068 & -0.2374 & -0.4134 & 0.448 & 0.621 & 0.579 & 0.386 \\
\hline KT07-06 & quenched & targeted & -0.3717 & -0.2283 & -0.2571 & -0.4300 & 0.425 & 0.591 & 0.553 & 0.372 \\
\hline KT07-07 & quenched & targeted & -0.2888 & -0.1910 & -0.1608 & -0.3695 & 0.514 & 0.644 & 0.691 & 0.427 \\
\hline KT07-08 & quenched & targeted & -0.2381 & -0.1600 & -0.0858 & -0.3340 & 0.578 & 0.692 & 0.821 & 0.463 \\
\hline KT07-09 & quenched & targeted & -0.2106 & -0.1391 & -0.1341 & -0.3460 & 0.616 & 0.726 & 0.734 & 0.451 \\
\hline KT07-10 & quenched & targeted & -0.2311 & -0.1359 & -0.1618 & -0.3569 & 0.587 & 0.731 & 0.689 & 0.440 \\
\hline KT07-01 & $\mathrm{ccc}$ & measured & -0.2501 & -0.1397 & -0.2050 & -0.3643 & 0.562 & 0.725 & 0.624 & 0.432 \\
\hline KT07-02 & $\mathrm{ccc}$ & measured & -0.2531 & -0.1465 & -0.1966 & -0.3854 & 0.558 & 0.714 & 0.636 & 0.412 \\
\hline KT07-03 & $\mathrm{ccc}$ & measured & -0.2119 & -0.1289 & -0.1485 & -0.3561 & 0.614 & 0.743 & 0.710 & 0.440 \\
\hline KT07-04 & $\mathrm{ccc}$ & measured & -0.2561 & -0.1578 & -0.2078 & -0.3711 & 0.554 & 0.695 & 0.620 & 0.426 \\
\hline KT07-05 & $\mathrm{ccc}$ & measured & -0.3560 & -0.1975 & -0.2582 & -0.4099 & 0.441 & 0.635 & 0.552 & 0.389 \\
\hline KT07-06 & $\mathrm{ccc}$ & measured & -0.3261 & -0.1849 & -0.2655 & -0.4067 & 0.472 & 0.653 & 0.543 & 0.392 \\
\hline KT07-07 & $\mathrm{ccc}$ & measured & -0.2936 & -0.1764 & -0.1861 & -0.3777 & 0.509 & 0.666 & 0.652 & 0.419 \\
\hline KT07-08 & $\mathrm{ccc}$ & measured & -0.2517 & -0.1359 & -0.1173 & -0.3281 & 0.560 & 0.731 & 0.763 & 0.470 \\
\hline KT07-09 & $\mathrm{ccc}$ & measured & -0.2478 & -0.1370 & -0.1676 & -0.3497 & 0.565 & 0.729 & 0.680 & 0.447 \\
\hline KT07-10 & $\mathrm{ccc}$ & measured & -0.2519 & -0.1281 & -0.1883 & -0.3455 & 0.560 & 0.745 & 0.648 & 0.451 \\
\hline KT07-01 & quenched & measured & -0.2485 & -0.1422 & -0.1999 & -0.3658 & 0.564 & 0.721 & 0.631 & 0.431 \\
\hline KT07-02 & quenched & measured & -0.2497 & -0.1343 & -0.1635 & -0.3647 & 0.563 & 0.734 & 0.686 & 0.432 \\
\hline KT07-03 & quenched & measured & -0.2255 & -0.1334 & -0.1244 & -0.3585 & 0.595 & 0.736 & 0.751 & 0.438 \\
\hline KT07-04 & quenched & measured & -0.2506 & -0.1495 & -0.1798 & -0.3639 & 0.562 & 0.709 & 0.661 & 0.433 \\
\hline KT07-05 & quenched & measured & -0.3588 & -0.1911 & -0.2371 & -0.4076 & 0.438 & 0.644 & 0.579 & 0.391 \\
\hline KT07-06 & quenched & measured & -0.3525 & -0.1898 & -0.2519 & -0.4154 & 0.444 & 0.646 & 0.560 & 0.384 \\
\hline KT07-07 & quenched & measured & -0.2792 & -0.1665 & -0.1459 & -0.3573 & 0.526 & 0.682 & 0.715 & 0.439 \\
\hline KT07-08 & quenched & measured & -0.2432 & -0.1402 & -0.0720 & -0.3208 & 0.571 & 0.724 & 0.847 & 0.478 \\
\hline KT07-09 & quenched & measured & -0.2093 & -0.1160 & -0.1230 & -0.3291 & 0.618 & 0.766 & 0.753 & 0.469 \\
\hline KT07-10 & quenched & measured & -0.2397 & -0.1216 & -0.1625 & -0.3445 & 0.576 & 0.756 & 0.688 & 0.452 \\
\hline
\end{tabular}


Exhibit B-1. KT07 PCT Measurements (as Common Logarithms) in Analytical Sequence by Element.

Variability Chart for log[B ppm]

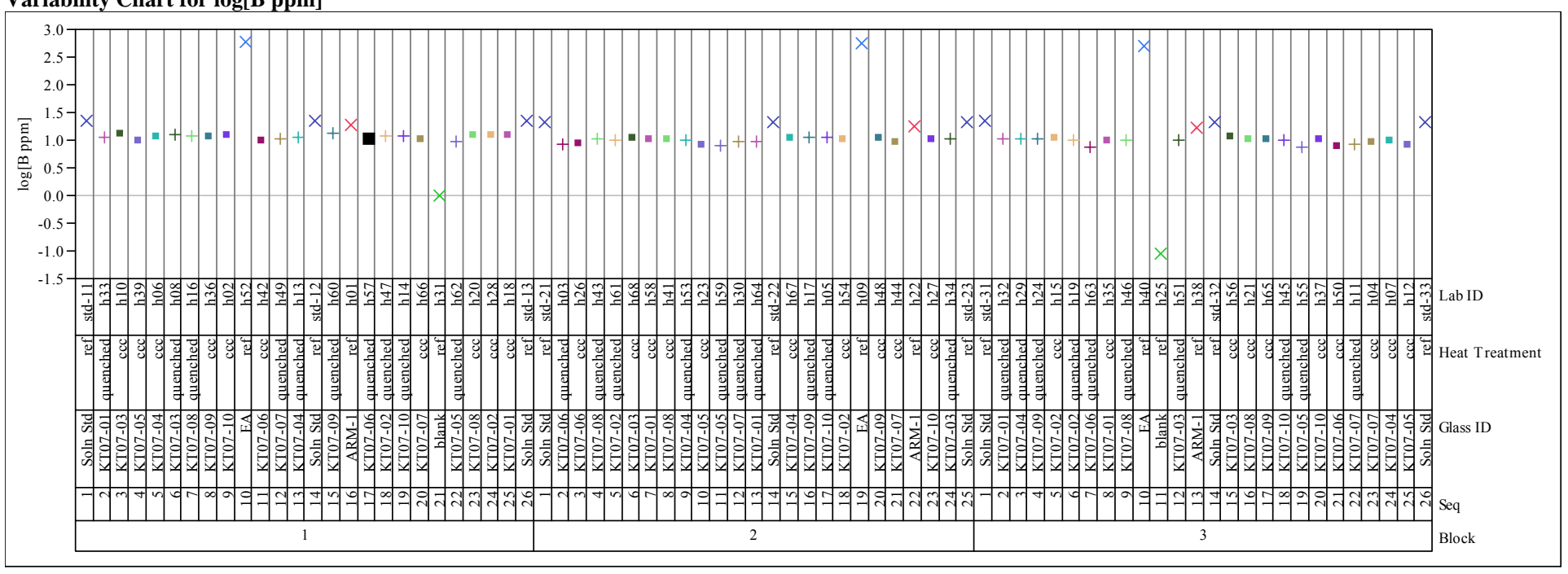

\section{Variability Chart for $\log [\mathrm{Li}$ ppm $]$}

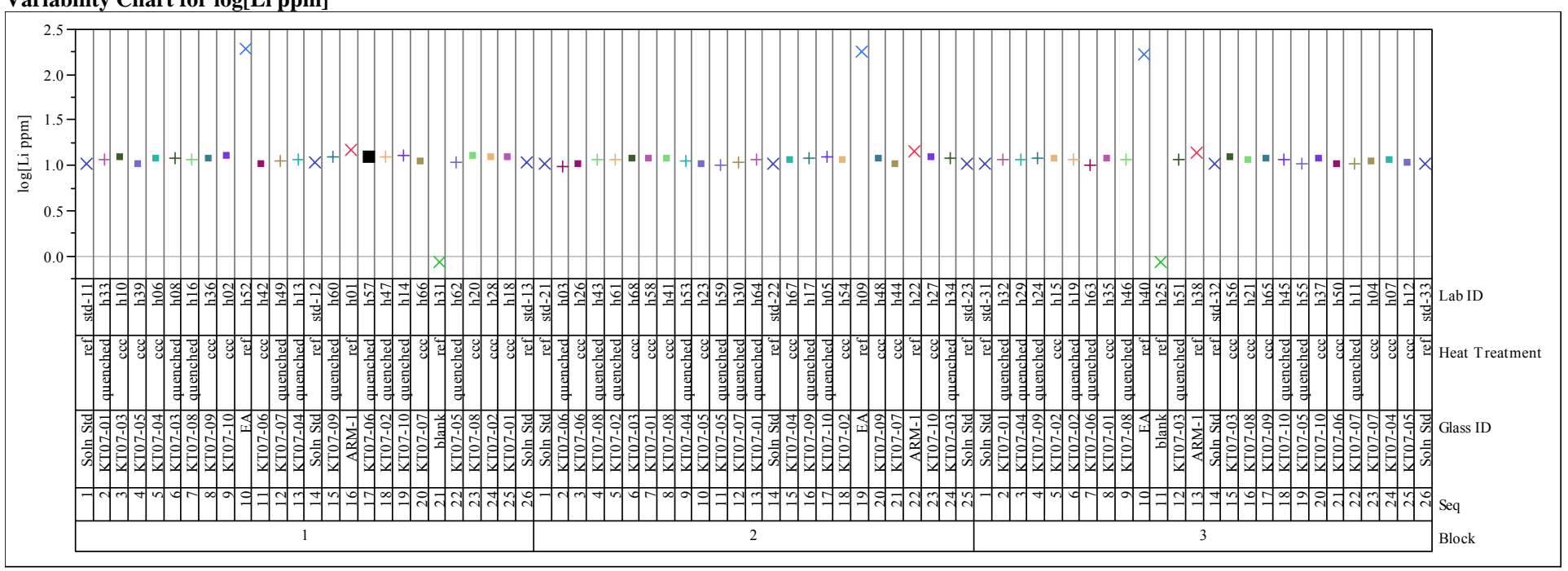


Exhibit B-1. KT07 PCT Measurements (as Common Logarithms) in Analytical Sequence by Element. (continued) Variability Chart for log[Na ppm]

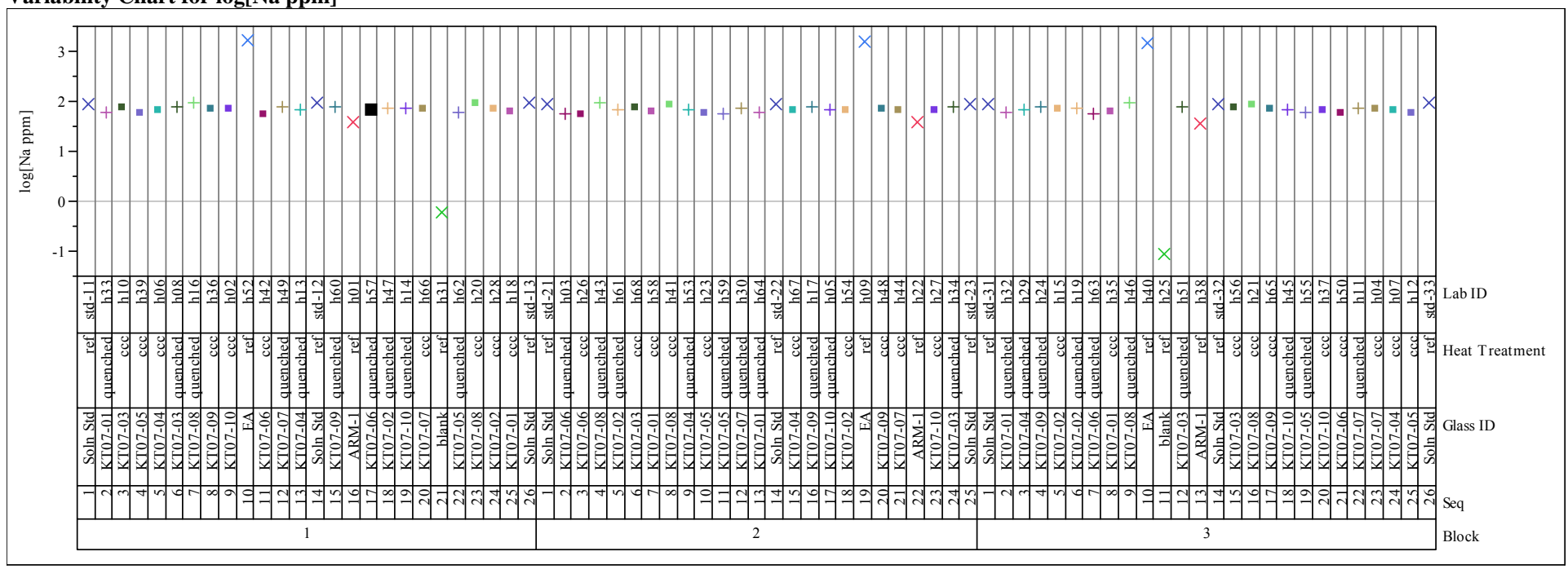

Variability Chart for log[Si ppm]

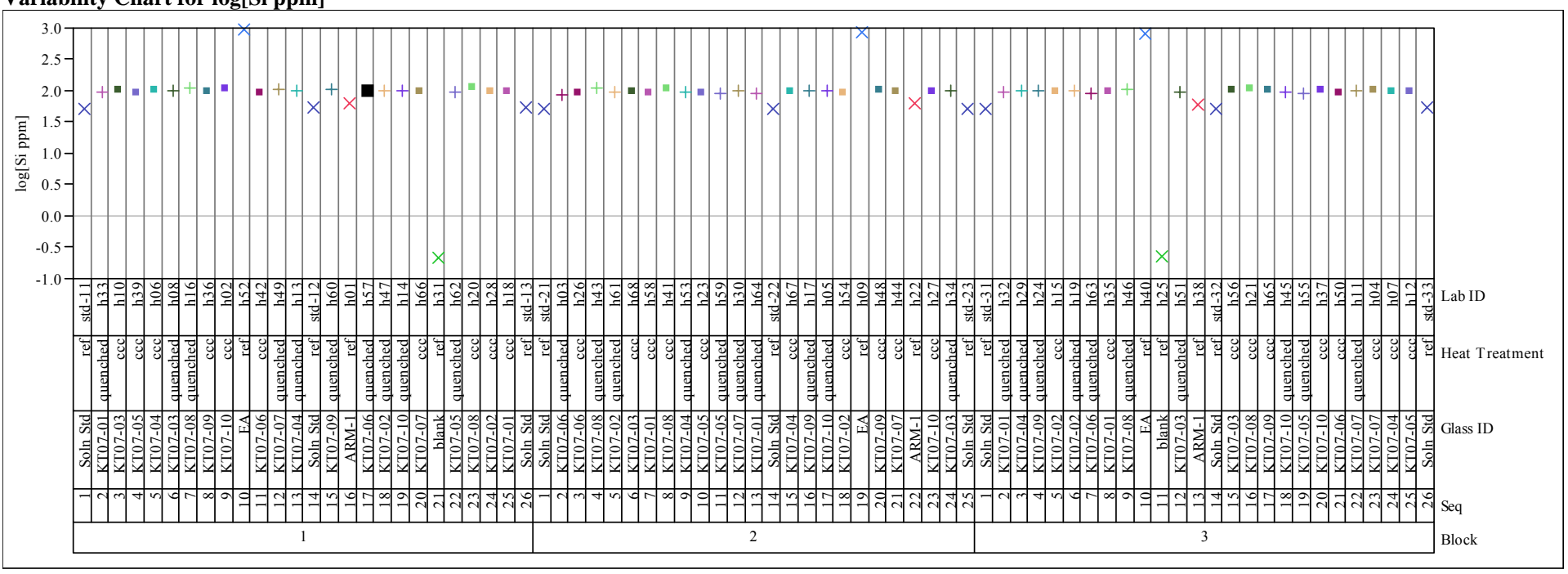


Exhibit B-2. Statistical Evaluation of the ICP-AES Calibration Effects from the Multi-Element Standard Solution Results by Oxide.

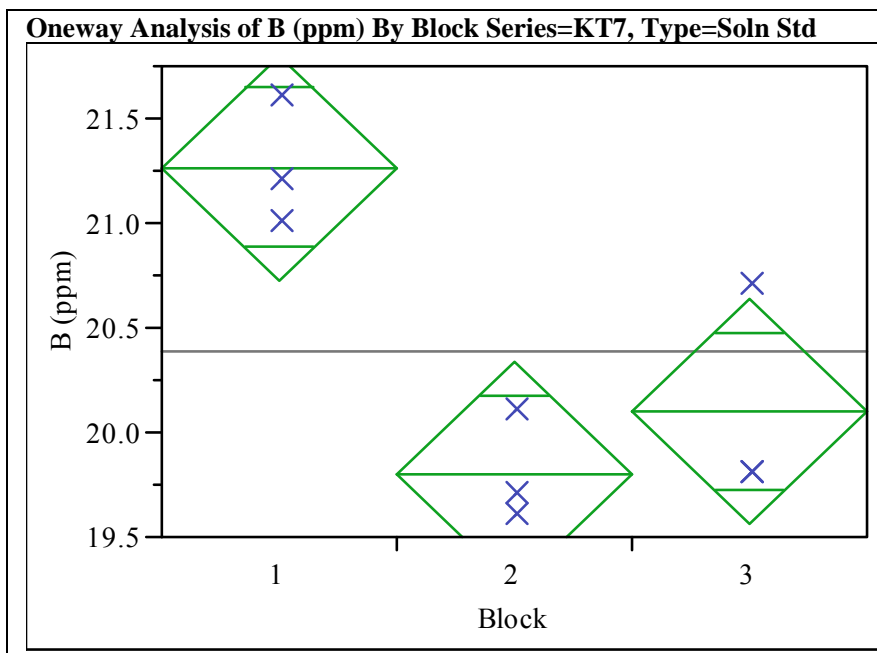

\section{Summary of Fit}

$\begin{array}{ll}\text { Rsquare } & 0.806067\end{array}$

$\begin{array}{ll}\text { Adj Rsquare } & 0.741422 \\ & 0.380058\end{array}$

Root Mean Square Error $\quad 0.380058$

Observations (or Sum Wgts) 9

\section{Analysis of Variance}

Source DF Sum of Squares Mean Square F Ratio Prob $>$ F

$\begin{array}{lrrrrr}\text { Block } & 2 & 3.6022222 & 1.80111 & 12.4692 & 0.0073\end{array}$

$\begin{array}{llll}\text { Error } & 6 & 0.8666667 & 0.14444\end{array}$

C. Total $8 \quad 4.4688889$

\section{Means for Oneway Anova}

Level Number Mean Std Error Lower 95\% Upper 95\%

$\begin{array}{lrrrrr}1 & 3 & 21.2667 & 0.21943 & 20.730 & 21.804 \\ 2 & 3 & 19.8000 & 0.21943 & 19.263 & 20.337\end{array}$

$\begin{array}{lllll}3 & 320.1000 & 0.21943 & 19.563 & 20.637\end{array}$

Std Error uses a pooled estimate of error variance

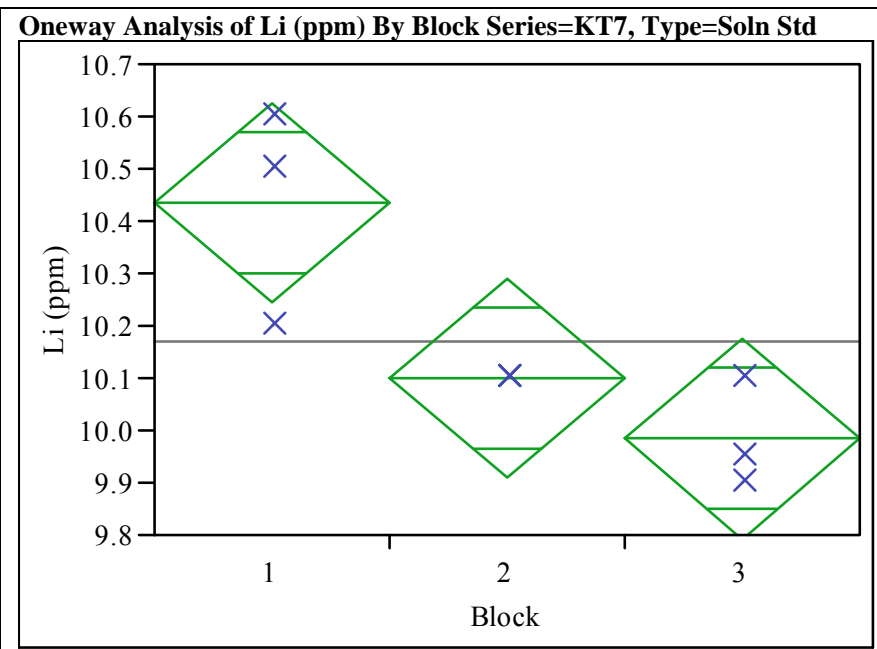

\section{Summary of Fit}

Rsquare

0.751276

Adj Rsquare

0.668367

Root Mean Square Error $\quad 0.134371$

Mean of Response

10.17222

Observations (or Sum Wgts)

Analysis of Variance

Source DF Sum of Squares Mean Square F Ratio Prob > F

$\begin{array}{llllll}\text { Block } & 2 & 0.32722222 & 0.163611 & 9.0615 & 0.0154\end{array}$

$\begin{array}{llll}\text { Error } & 6 & 0.10833333 & 0.018056\end{array}$

C. Total $8 \quad 0.43555556$

\section{Means for Oneway Anova}

Level Number Mean Std Error Lower 95\% Upper 95\%

$\begin{array}{llllll}1 & 3 & 10.4333 & 0.07758 & 10.244 & 10.623\end{array}$

$\begin{array}{rrrrrr}2 & 3 & 10.1000 & 0.07758 & 9.910 & 10.290 \\ 3 & 3 & 9.9833 & 0.07758 & 9.794 & 10.173\end{array}$

Std Error uses a pooled estimate of error variance 
Exhibit B-2. Statistical Evaluation of the ICP-AES Calibration Effects from the Multi-Element Standard Solution Results by Oxide. (continued)

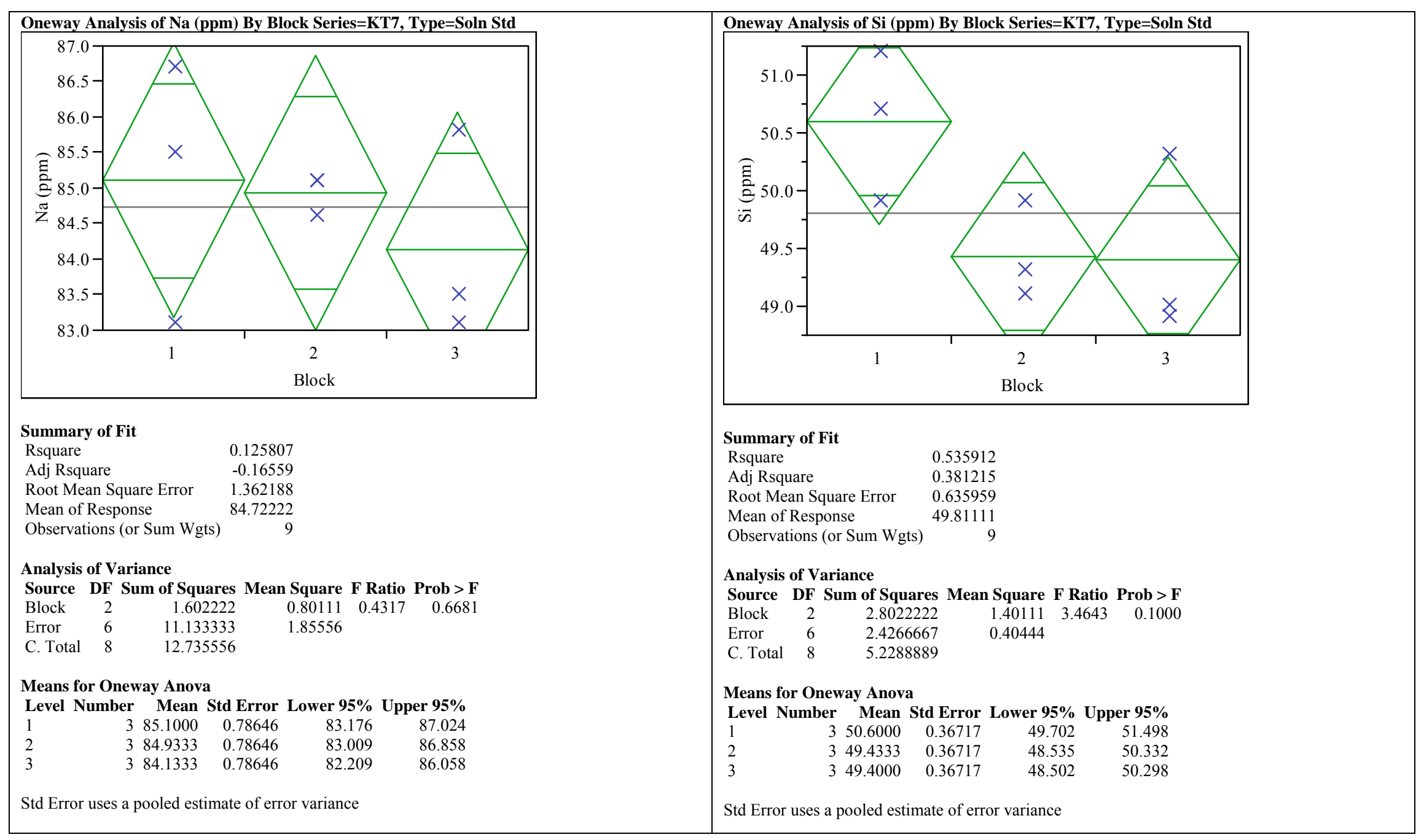


Exhibit B-3. KT07 PCT Results (as Common Logarithms) Grouped by Glass ID and Heat Treatment.

Variability Chart for log[B ppm]

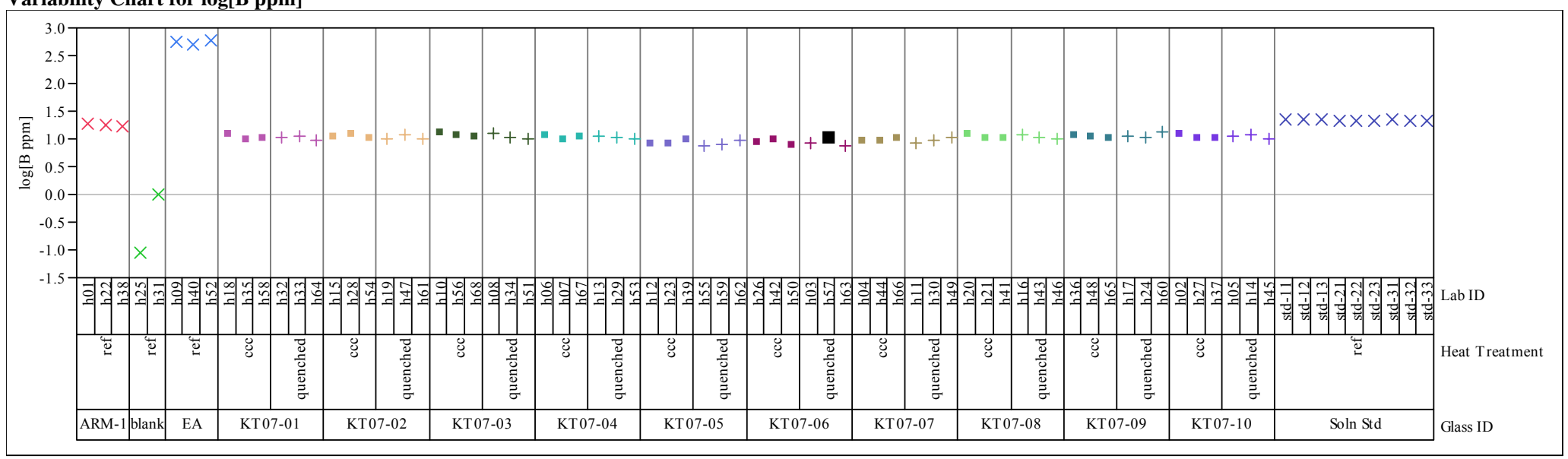

Variability Chart for $\log [\mathrm{Li} \mathrm{ppm]}$

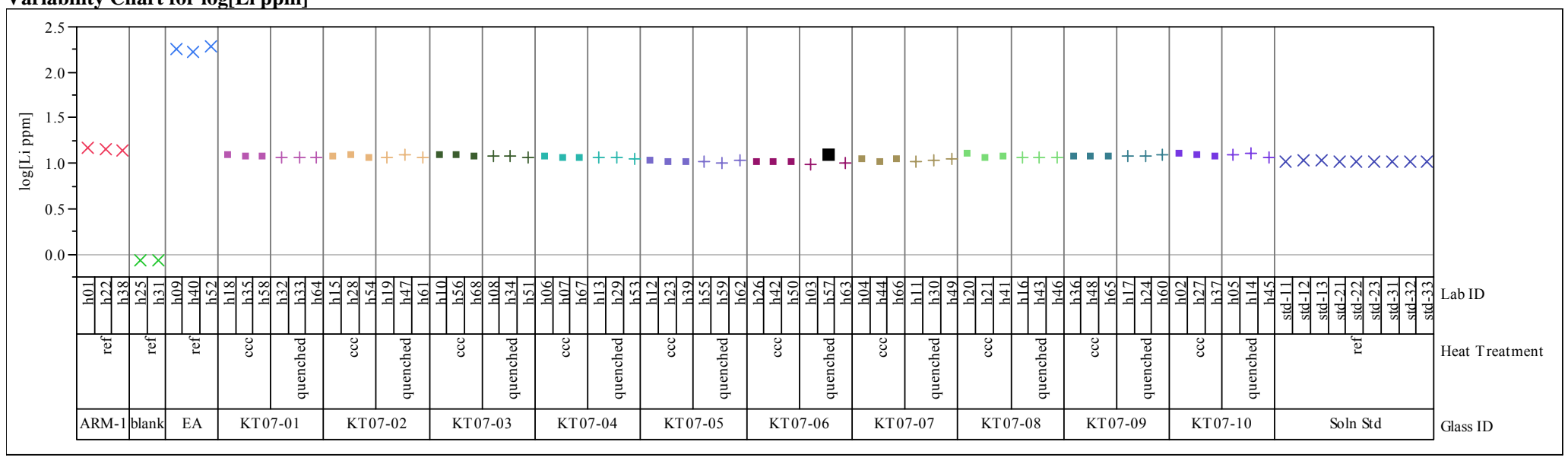




\section{Exhibit B-3. KT07 PCT Results (as Common Logarithms) Grouped by Glass ID and Heat Treatment. (continued)} Variability Chart for log[Na ppm]
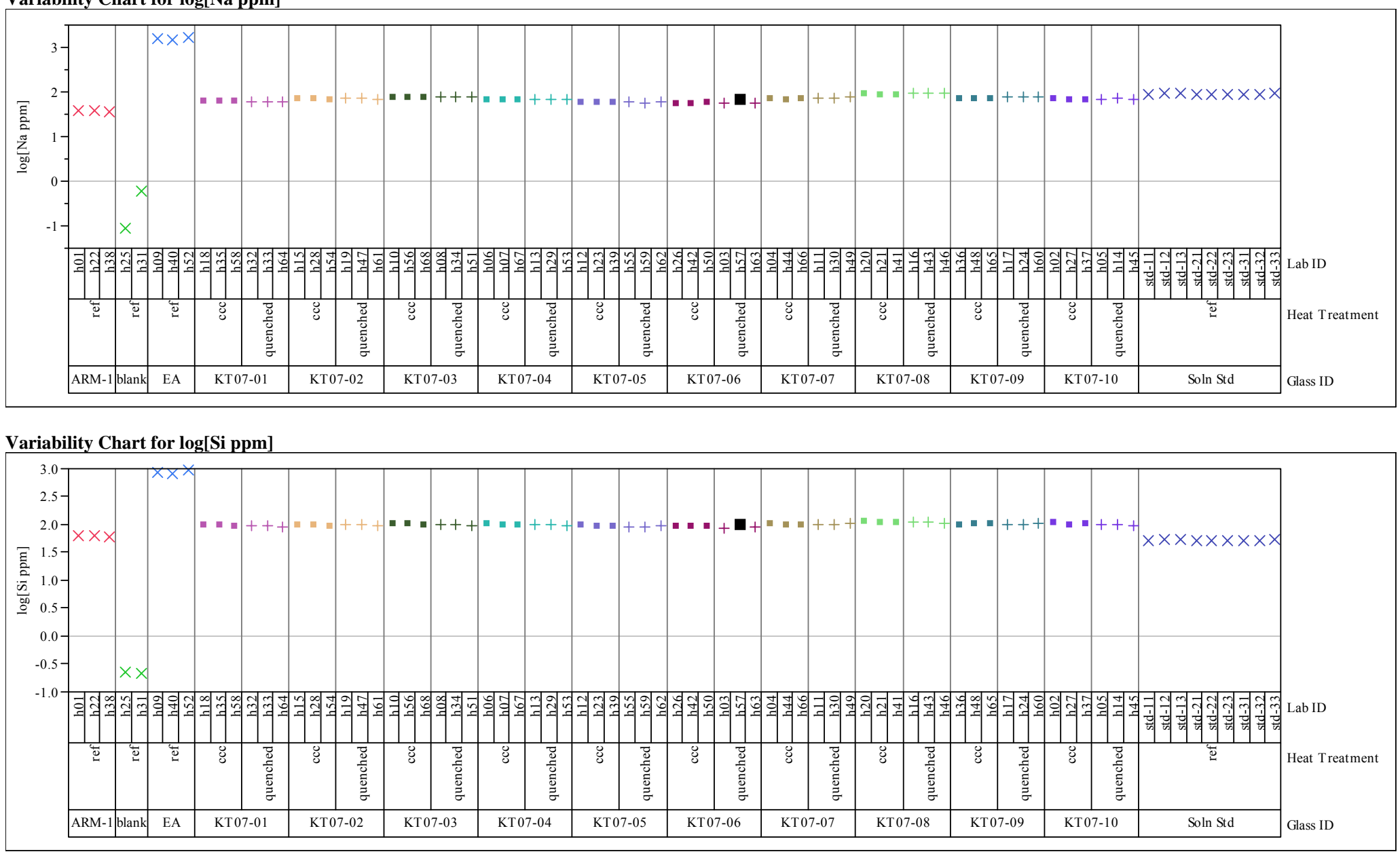


\section{Exhibit B-4. Correlations among the Normalized PCT Results} for the KT07-Series Glasses (as common logarithms).

(Over All Comp Views and Heat Treatments)

$\begin{array}{ccccc}\text { Multivariate Correlations: } & & & \\ & \log \mathbf{N L}[\mathbf{B}(\mathbf{g} / \mathbf{L})] & \log \mathbf{N L}[\mathbf{L i}(\mathbf{g} / \mathbf{L})] & \log \mathbf{N L}[\mathbf{N a}(\mathbf{g} / \mathbf{L})] & \log \mathbf{N L}[\mathbf{S i}(\mathbf{g} / \mathbf{L})] \\ \log \mathrm{NL}[\mathrm{B}(\mathrm{g} / \mathrm{L})] & 1.0000 & 0.9954 & 0.9874 & 0.9787 \\ \log \mathrm{NL}[\mathrm{Li}(\mathrm{g} / \mathrm{L})] & 0.9954 & 1.0000 & 0.9855 & 0.9855 \\ \log \mathrm{NL}[\mathrm{Na}(\mathrm{g} / \mathrm{L})] & 0.9874 & 0.9855 & 1.0000 & 0.9885 \\ \log \mathrm{NL}[\mathrm{Si}(\mathrm{g} / \mathrm{L})] & 0.9787 & 0.9855 & 0.9885 & 1.0000\end{array}$

\section{Scatterplot Matrix}

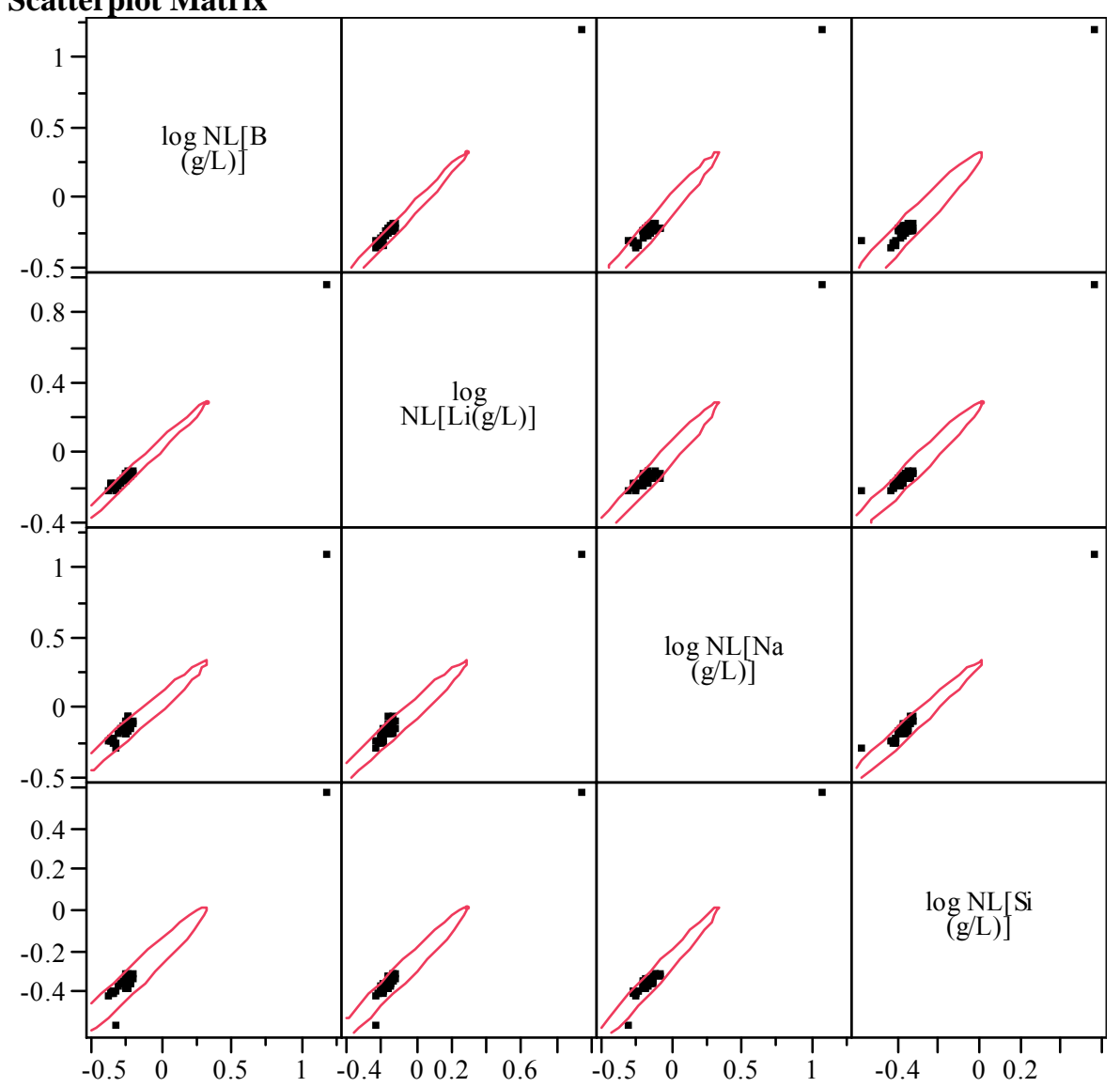


Exhibit B-5. Normalized PCT Response by Compositional View and Heat Treatment for the KT7-Series Glasses.

Variability Chart for $\log$ NL[B $(\mathrm{g} / \mathrm{L})]$

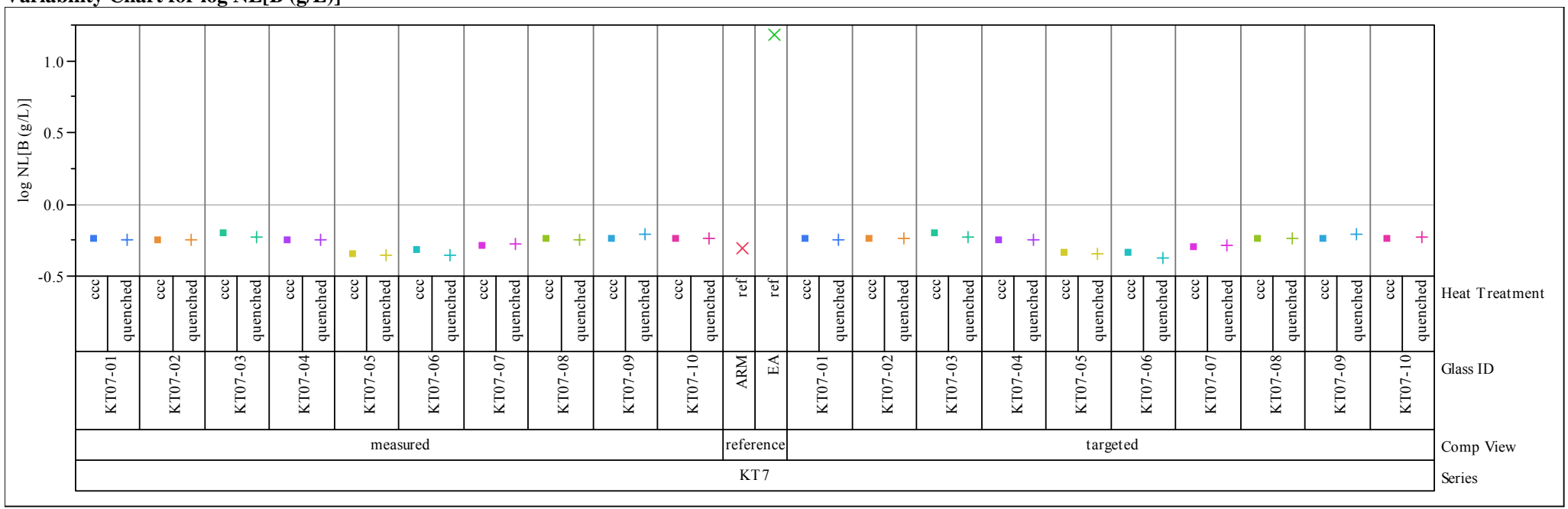

Variability Chart for $\log \mathrm{NL}[\mathrm{Li}(\mathrm{g} / \mathrm{L})]$

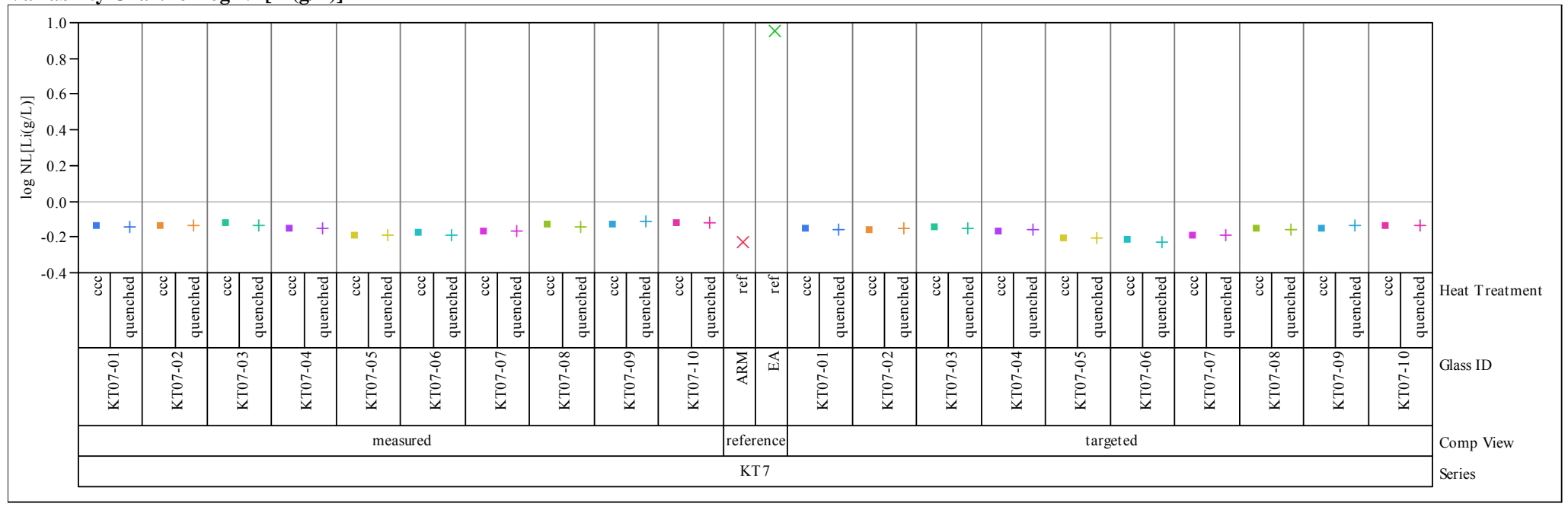




\section{Exhibit B-5. Normalized PCT Response by Compositional View and Heat Treatment for the KT7-Series Glasses. (continued)} Variability Chart for $\log \mathrm{NL}[\mathrm{Na}(\mathrm{g} / \mathrm{L})]$

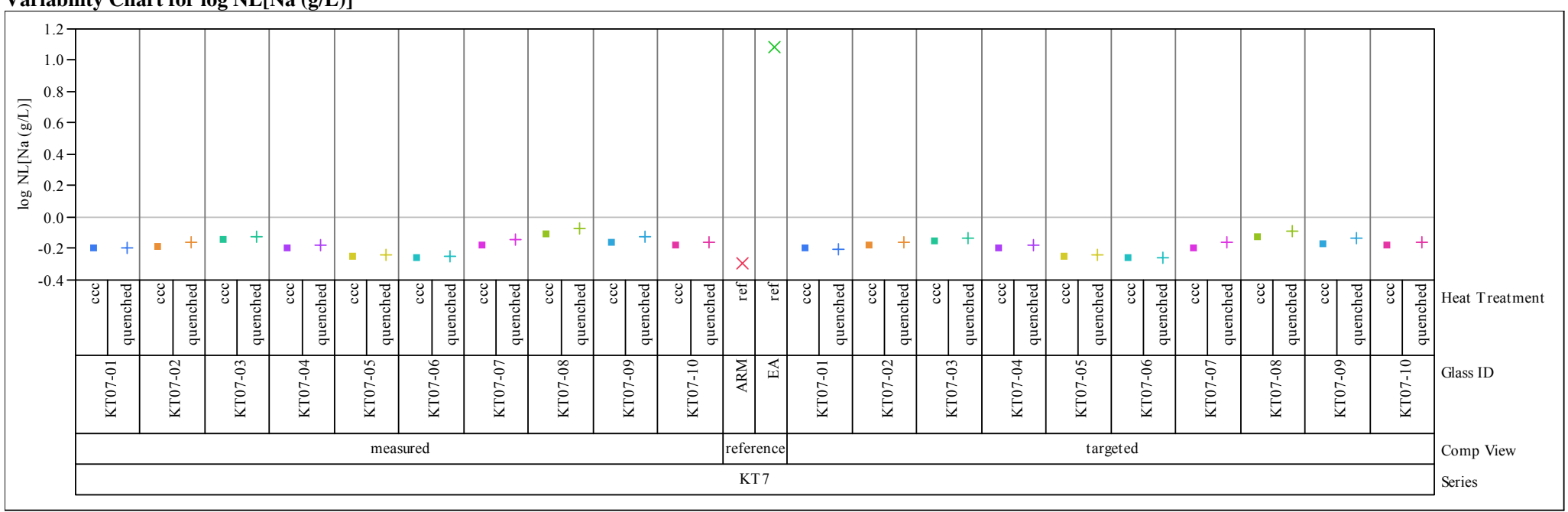

Variability Chart for $\log$ NL[Si $(g / L)]$

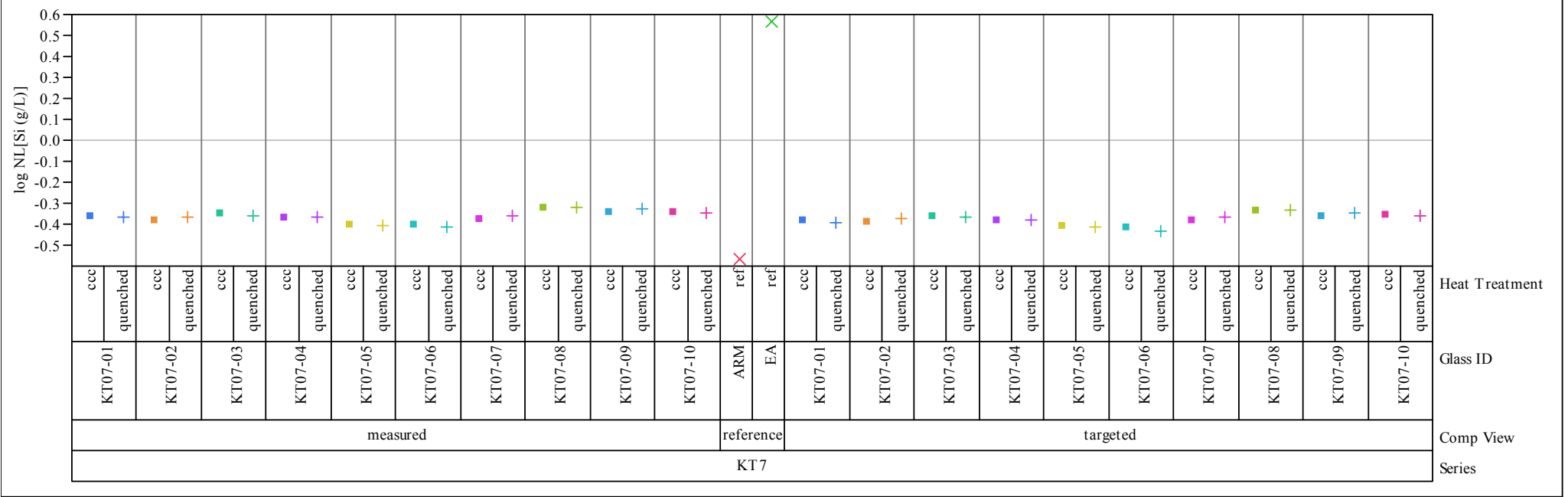


Exhibit B-6. PCT Measurements versus Durability Model Predictions for the KT07 Series Glasses.

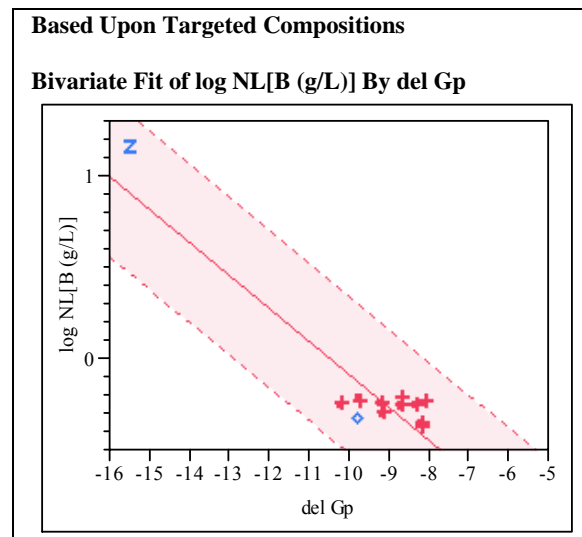

Bivariate Fit of log NL[Li (g/L)] By del Gp

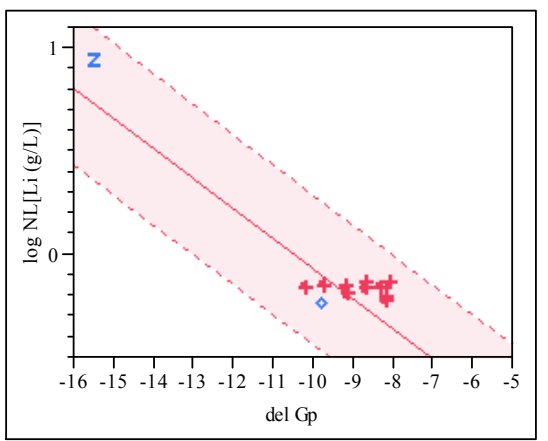

Bivariate Fit of $\log \mathrm{NL}[\mathrm{Na}(\mathrm{g} / \mathrm{L})]$ By del Gp

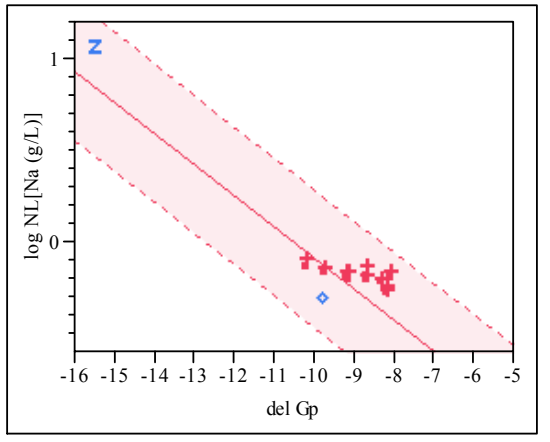

Bivariate Fit of log NL[Si (g/L)] By del Gp

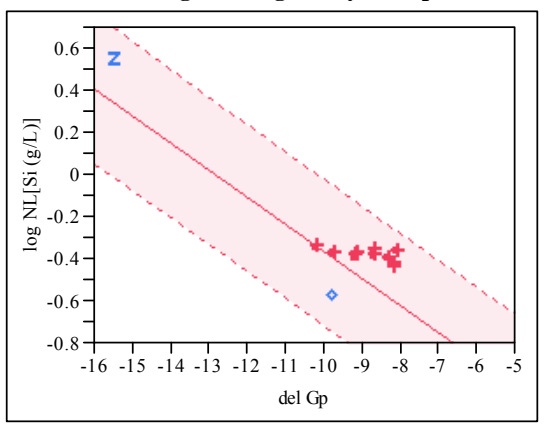

Based Upon Measured Compositions

Bivariate Fit of log NL[B (g/L)] By del Gp

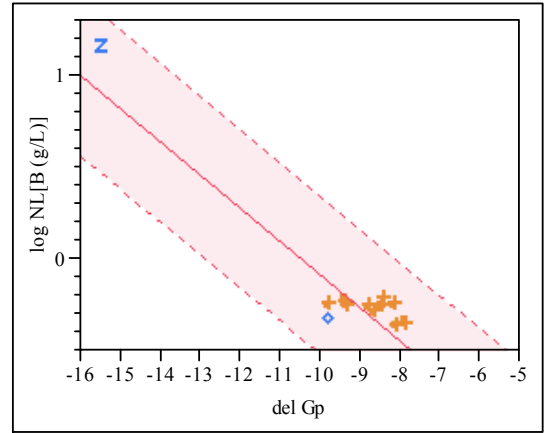

Bivariate Fit of log NL[Li (g/L)] By del Gp

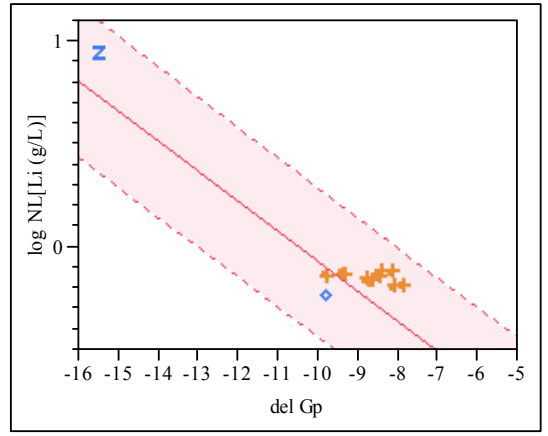

Bivariate Fit of log NL[Na (g/L)] By del Gp

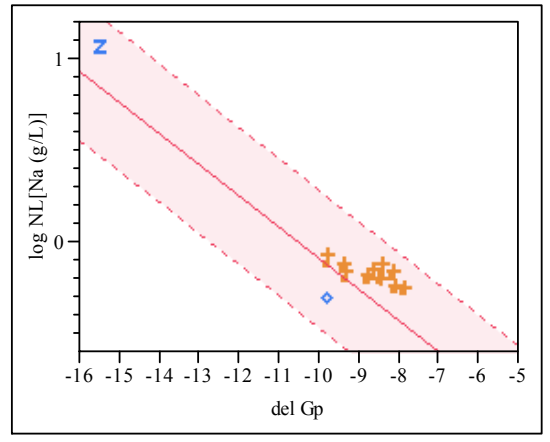

Bivariate Fit of log NL[Si (g/L)] By del Gp

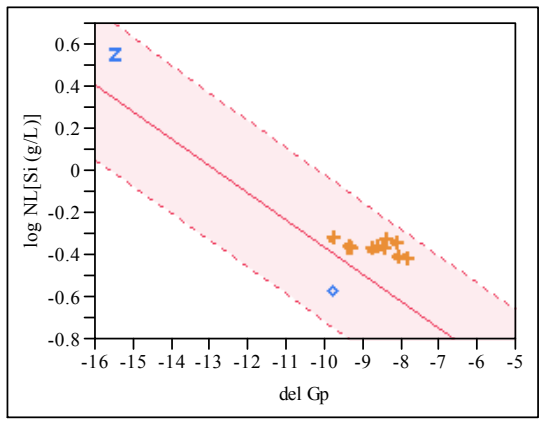


Appendix C. Results from Fitting Fulcher Equations to the Viscosity Measurements for the KT07 Glasses 
Exhibit C-1. Results of Fitting Fulcher Equations to the KT07-Series Viscosity Data.

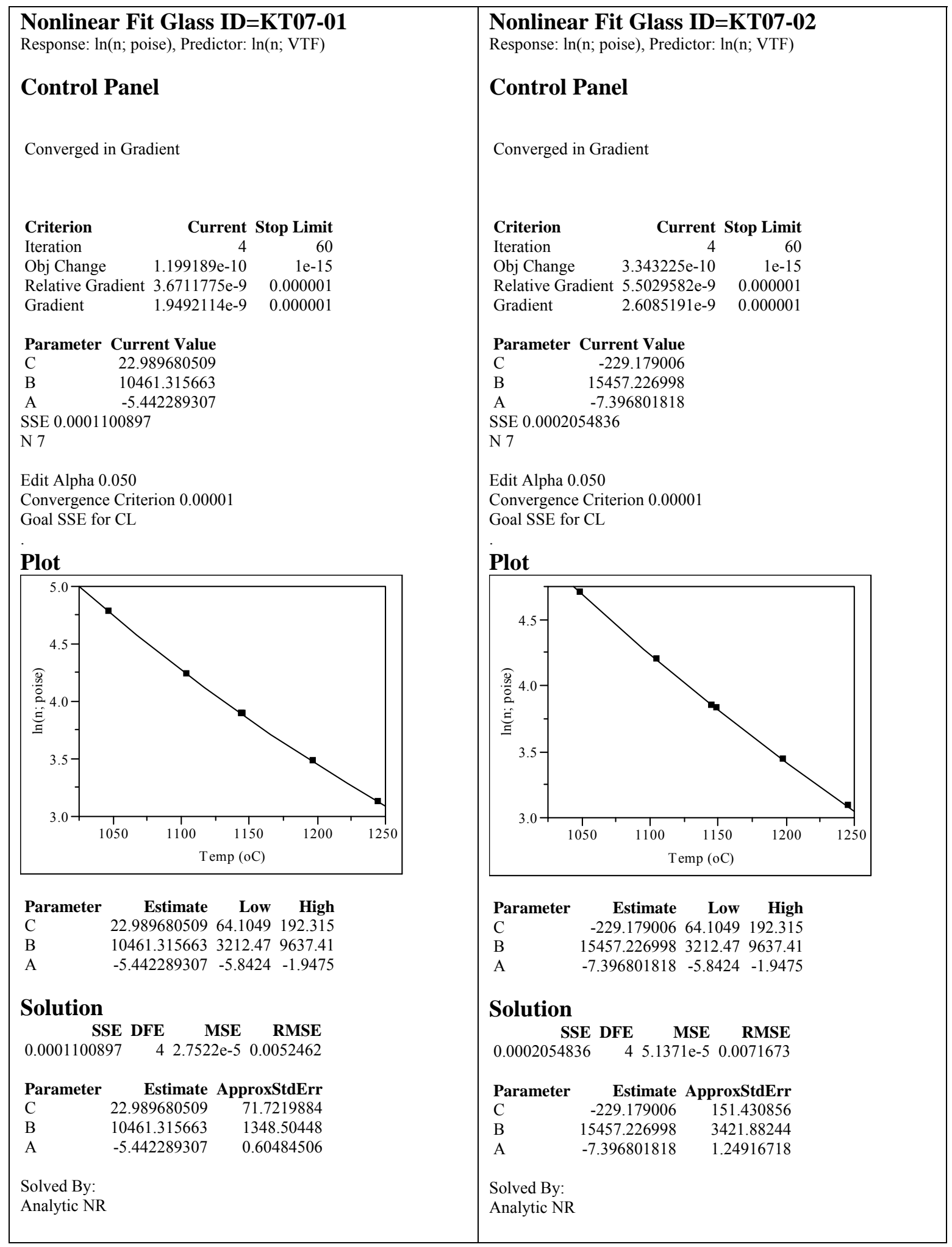




\section{Exhibit C-1. Results of Fitting Fulcher Equations to the KT07-Series Viscosity Data.} (continued)

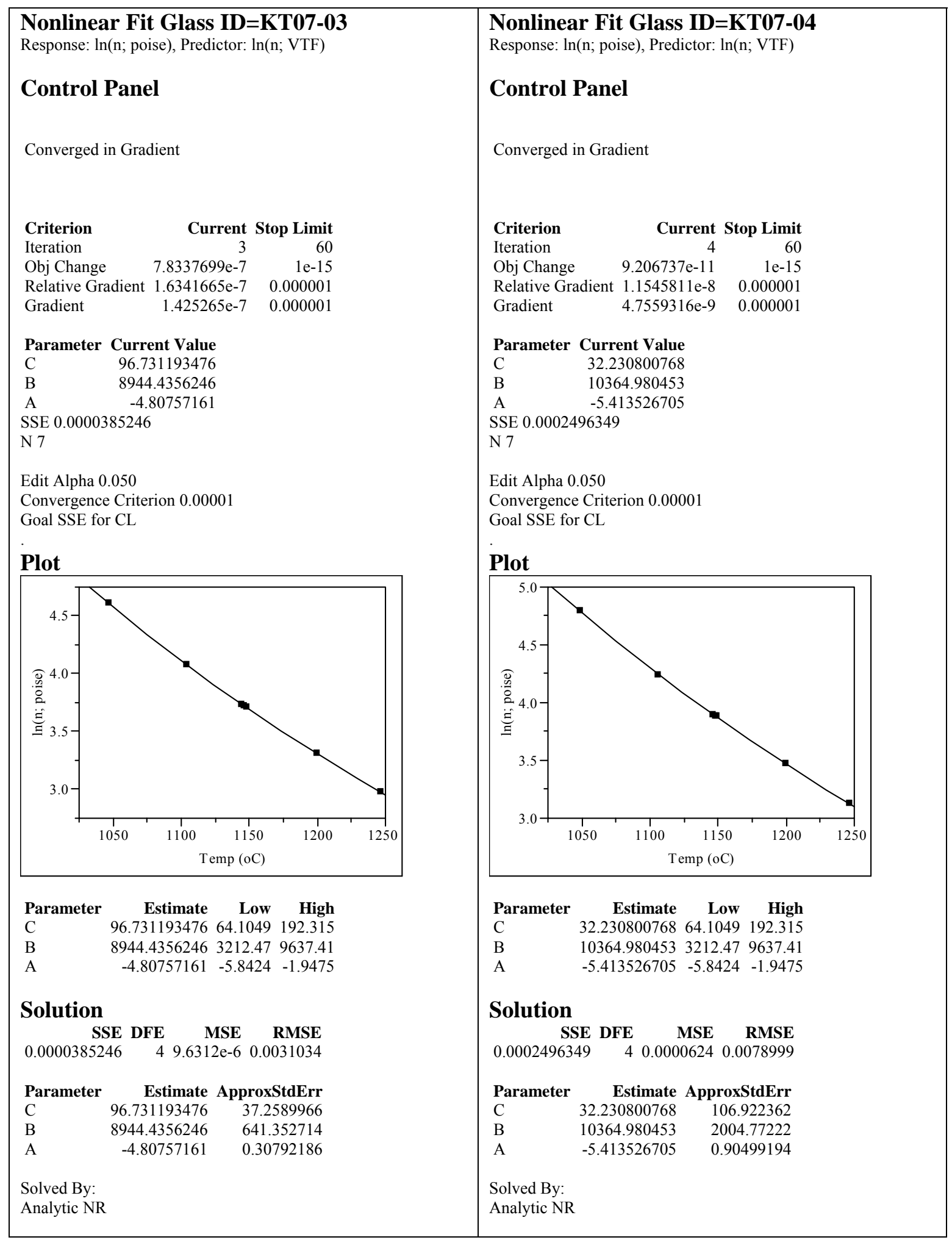




\section{Exhibit C-1. Results of Fitting Fulcher Equations to the KT07-Series Viscosity Data.} (continued)

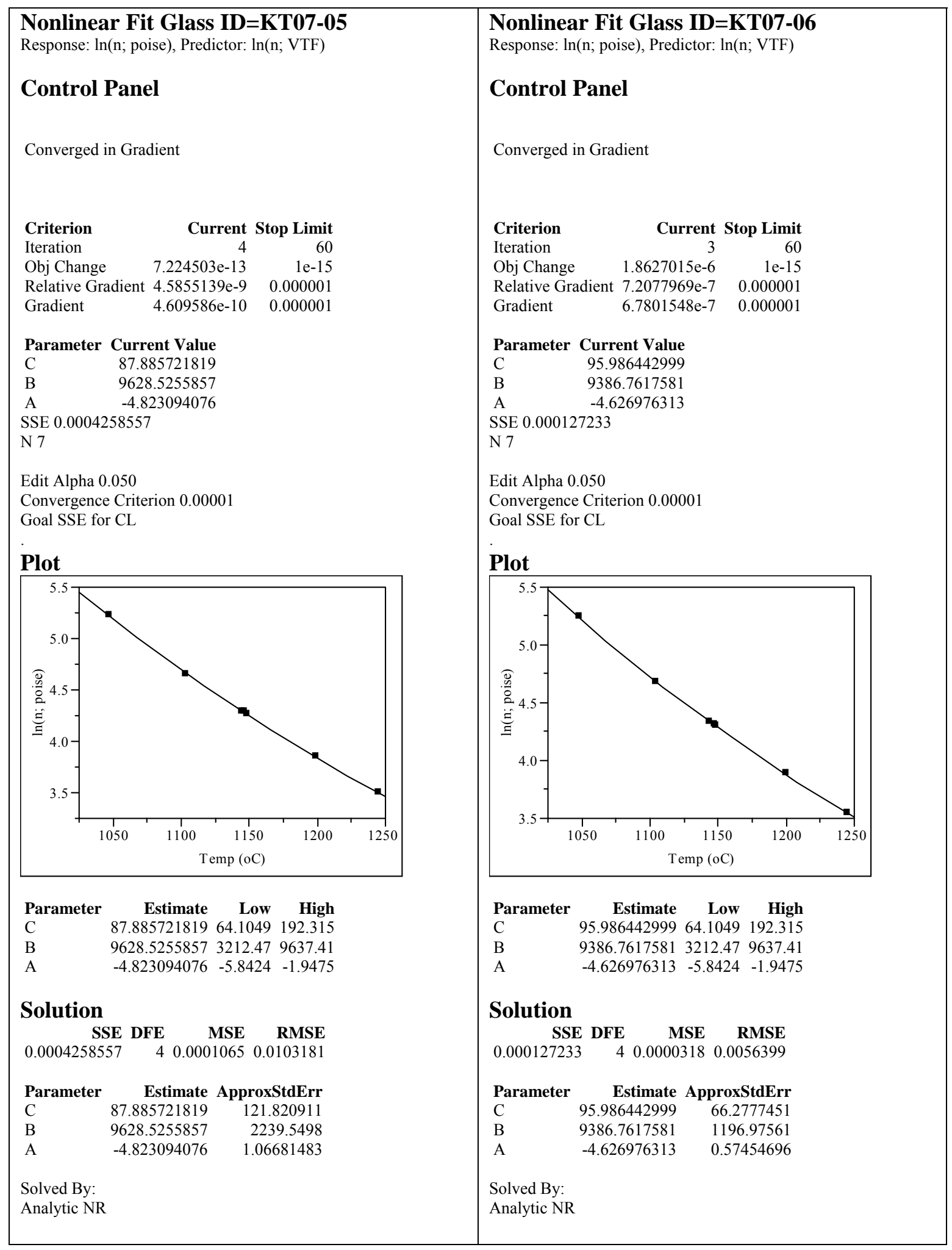




\section{Exhibit C-1. Results of Fitting Fulcher Equations to the KT07-Series Viscosity Data.} (continued)

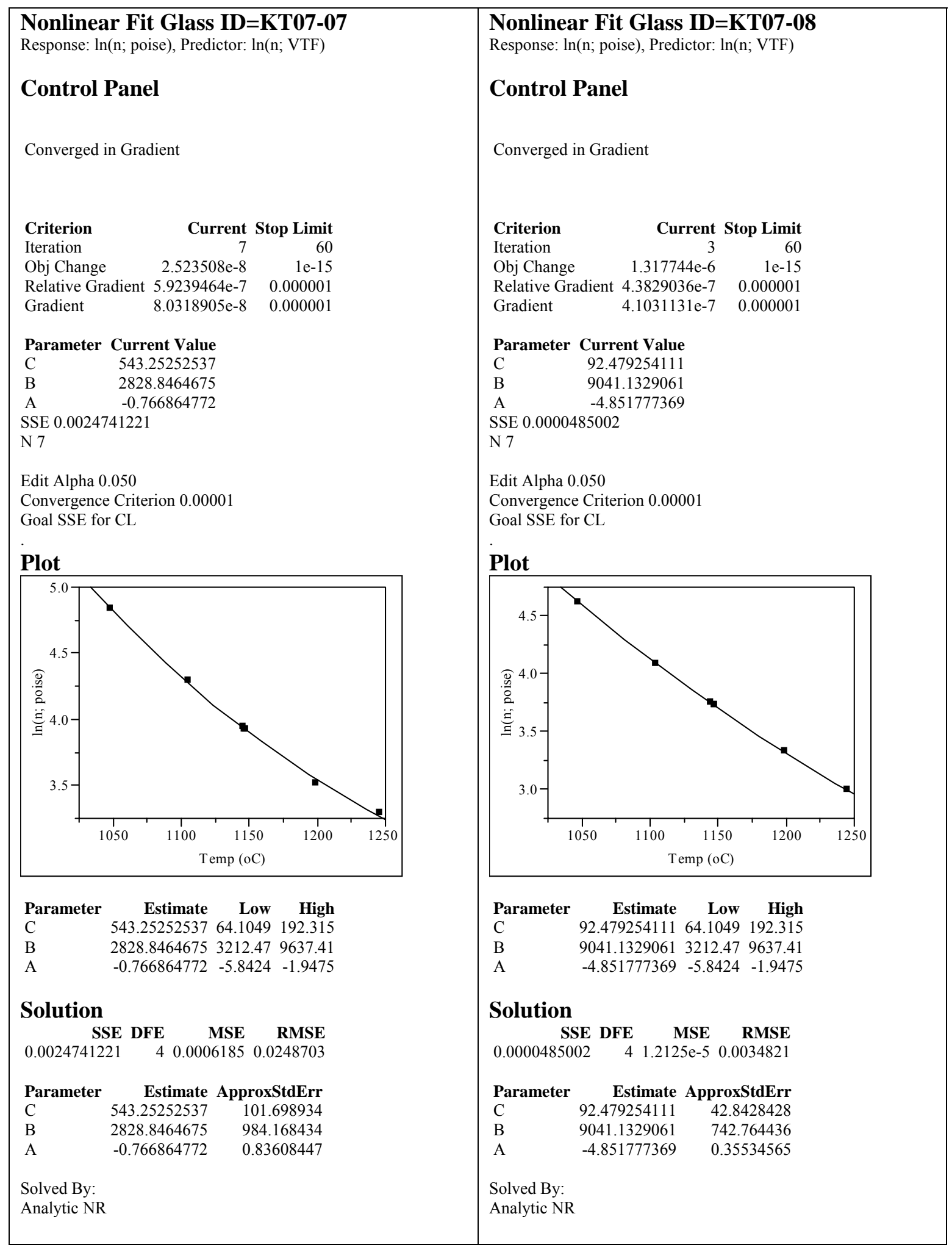




\section{Exhibit C-1. Results of Fitting Fulcher Equations to the KT07-Series Viscosity Data.} (continued)

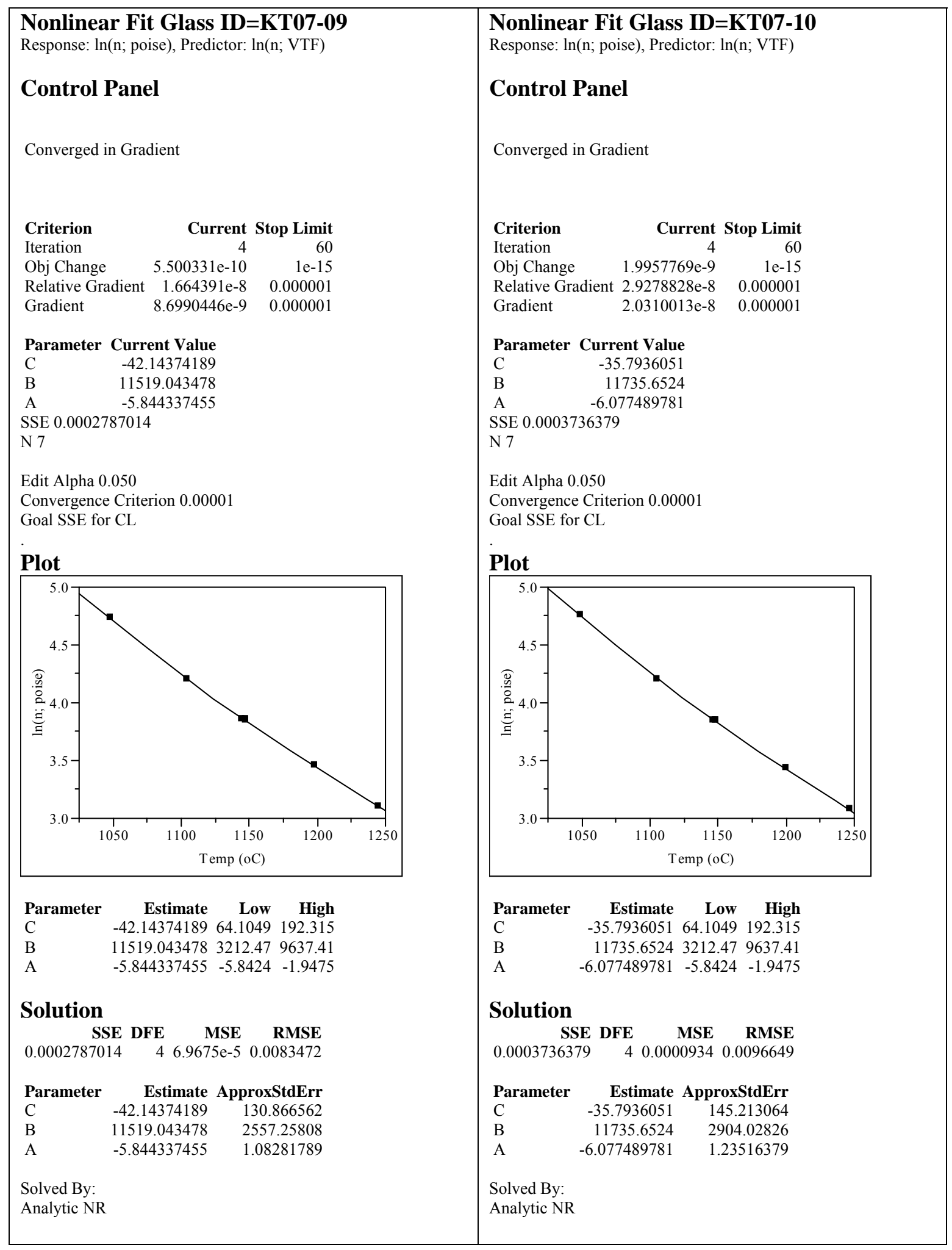


Exhibit C-2. Plot of Predicted versus Measured Viscosity Values for the KT07-Series Glasses with 95\% Confidence Intervals (CI).

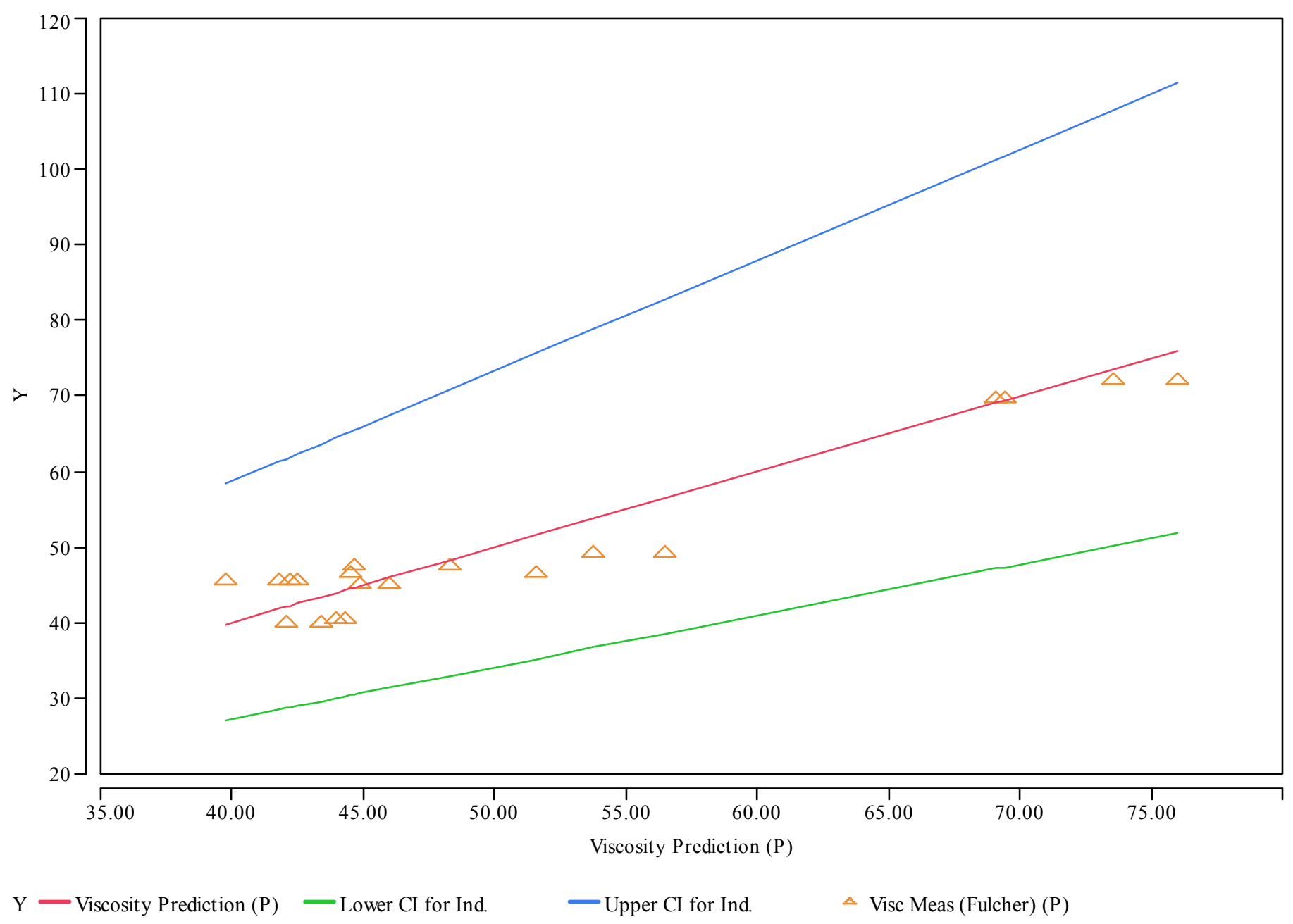


Table C-1. Predicted and Measured Viscosity Values for the KT07-Series Glasses with Confidence Intervals (CI).

\begin{tabular}{|c|c|c|c|c|c|c|}
\hline Glass ID & $\begin{array}{c}\text { Compositional } \\
\text { View }\end{array}$ & $\begin{array}{l}\text { Viscosity Model } \\
\text { Prediction (P) }\end{array}$ & $\begin{array}{l}\text { Lower CI for } \\
\text { Precition (P). }\end{array}$ & $\begin{array}{c}\text { Upper CI for } \\
\text { Prediction (P) }\end{array}$ & $\begin{array}{l}\text { Measured Viscosity } \\
\text { (Fulcher) (P) }\end{array}$ & Predictable? \\
\hline KT07-01 & targeted & 51.59 & 35.19 & 75.62 & 46.53 & yes \\
\hline KT07-02 & targeted & 45.99 & 31.37 & 67.43 & 45.18 & yes \\
\hline KT07-03 & targeted & 42.09 & 28.70 & 61.72 & 39.83 & yes \\
\hline KT07-04 & targeted & 48.32 & 32.96 & 70.83 & 47.44 & yes \\
\hline KT07-05 & targeted & 69.08 & 47.14 & 101.24 & 69.57 & yes \\
\hline KT07-06 & targeted & 73.57 & 50.20 & 107.82 & 72.15 & yes \\
\hline KT07-07 & targeted & 53.79 & 36.70 & 78.85 & 49.18 & yes \\
\hline KT07-08 & targeted & 43.94 & 29.97 & 64.44 & 40.35 & yes \\
\hline KT07-09 & targeted & 42.51 & 28.99 & 62.33 & 45.52 & yes \\
\hline KT07-10 & targeted & 42.24 & 28.81 & 61.95 & 45.58 & yes \\
\hline KT07-01 & measured & 44.54 & 30.38 & 65.30 & 46.53 & yes \\
\hline KT07-02 & measured & 44.87 & 30.60 & 65.79 & 45.18 & yes \\
\hline KT07-03 & measured & 43.37 & 29.58 & 63.59 & 39.83 & yes \\
\hline KT07-04 & measured & 44.68 & 30.47 & 65.51 & 47.44 & yes \\
\hline KT07-05 & measured & 69.41 & 47.36 & 101.72 & 69.57 & yes \\
\hline KT07-06 & measured & 76.00 & 51.86 & 111.38 & 72.15 & yes \\
\hline KT07-07 & measured & 56.51 & 38.55 & 82.82 & 49.18 & yes \\
\hline KT07-08 & measured & 44.34 & 30.24 & 65.02 & 40.35 & yes \\
\hline KT07-09 & measured & 41.80 & 28.50 & 61.30 & 45.52 & yes \\
\hline KT07-10 & measured & 39.79 & 27.13 & 58.36 & 45.58 & yes \\
\hline
\end{tabular}




\section{Distribution:}

J. W. Amoroso, 999-W

C. J. Bannochie, 773-42A

A. B. Barnes, 999-W

A. L. Billings, 999-W

J. M. Bricker, 704-27S

M. A. Broome, 704-29S

C. L. Crawford, 773-42A

D. A. Crowley, 773-43A

R. E. Edwards, 766-H

T. B. Edwards, 999-W

T. L. Fellinger, 704-26S

S. D. Fink, 773-A

K. M. Fox, 999-W

B. J. Giddings, 786-5A

J. M. Gillam, 766-H

B. A. Hamm, 766-H

C. C. Herman, 999-W

D. T. Herman, 735-11A

R. N. Hinds, 704-S

E. W. Holtzscheiter, 704-15S
T. H. Huff, 766-H

J. F. Iaukea, 704-30S

P. R. Jackson, 703-46A

C. M. Jantzen, 773-A

F. C. Johnson, 999-W

D. C. Koopman, 999-W

D. D. Larsen, 766-H

P. L. Lee, 703-41A

S. L. Marra, 773-A

D. H. Miller, 999-W

J. E. Occhipinti, 704-S

D. K. Peeler, 999-W

F. M. Pennebaker, 773-42A

J. W. Ray, 704-S

M. A. Rios-Armstrong, 766-H

H. B. Shah, 766-H

D. C. Sherburne, 704-S

A. V. Staub, 704-27S

M. E. Stone, 999-W

J. P. Vaughan, 773-41A 